MARIVALDE MOACIR FRANCELIN

\title{
ORDEM DOS CONCEITOS NA ORGANIZAÇÃO DA INFORMAÇÃO E DO CONHECIMENTO
}

Tese apresentada ao Programa de Pós-Graduação em Ciência da Informação da Escola de Comunicações

e Artes (ECA) da Universidade de São Paulo (USP) como exigência para a obtenção do título de doutor em Ciência da Informação.

Área de concentração: Cultura e Informação. Linha de Pesquisa: Organização da Informação e do Conhecimento.

Orientadora: Profa. Dra. Nair Yumiko Kobashi.

São Paulo

2010 


\section{ORDEM DOS CONCEITOS NA ORGANIZAÇÃO DA INFORMAÇÃO E DO CONHECIMENTO}

Tese apresentada ao Programa de Pós-Graduação em Ciência da Informação da Escola de Comunicações

e Artes (ECA) da Universidade de São Paulo (USP) como exigência para a obtenção do título de doutor em Ciência da Informação. Área de concentração: Cultura e Informação. Linha de Pesquisa: Organização da Informação e do Conhecimento. Orientadora: Profa. Dra. Nair Yumiko Kobashi.

Banca Examinadora:

Profa. Dra. Nair Yumiko Kobashi (Orientadora)

Profa. Dra. Anna Maria Marques Cintra

Profa. Dra. Leilah Santiago Bufrem

Profa. Dra. Gercina Ângela Borém de Oliveira Lima

Profa. Dra. Giulia Crippa 
Para minha família: Moacir (in memorian), Mercêdes, Magda e Margarete. 


\section{Agradecimentos}

À minha orientadora, Profa. Dra. Nair Yumiko Kobashi, pela confiança, por acreditar em minhas idéias, me conduzir neste trabalho e pela disposição constante e serena ao diálogo.

Às professoras que participaram de minha qualificação: profa. Dra. Anna Maria Marques Cintra e profa. Dra. Marilda Lopes Ginez de Lara.

Aos professores e amigos, João de Melo Maricato, Fábio Mascarenhas e Silva e Mônica de Fátima Loureiro, por participarem deste trabalho e, principalmente, pelo incentivo e pelas boas conversas.

Aos velhos amigos, Denílson, Adriano, Roberto e Marcelo, que sempre estiveram presentes nos momentos mais dificeis, ouvindo-me pacientemente e com interesse sincero; não tenho palavras para expressar minha gratidão.

Ao $C N P q$ pelo fomento à primeira parte da pesquisa.

Por fim, meu agradecimento especial a Márcia. Companheira de todas as horas que, com sua grandeza de espírito, aceitou o desafio e seguiu lado a lado comigo neste trabalho, ensinando-me o quão leve pode ser a vida. 
Quanto a mim, contento-me com palavras humildes, desprezadas, informes; a mim agrada-me recolher o que cai de vossa mesa durante os vossos festins.

(Do Imaculado Conhecimento) Nietzsche 


\title{
Resumo
}

A abordagem teórica do conceito, que remonta à filosofia clássica, atravessou diversos períodos e correntes de pensamento, até chegar às abordagens contemporâneas. Os conceitos são também objetos de pesquisa consolidados na área da Organização da informação e do conhecimento, tendo recebido influências de algumas correntes filosóficas. Esta pesquisa procurou identificar as principais linhas teóricas que fundamentam as abordagens sobre o conceito na área. Parte da hipótese de que estas linhas não estão suficientemente explicitadas e que novas abordagens sobre o conceito contribuiriam para o fortalecimento da área. Para fundamentar a pesquisa, foi realizada revisão de literatura sobre o conceito na filosofia e na ciência, discutindo, ainda, questões como a metáfora e a linguagem na ordem dos conceitos. Apresenta as concepções sobre o conceito nas perspectivas de Foucault, Deleuze e Guattari, Gilles-Gaston Granger, Eleanor Rosch e Vygotsky. Discute as definições do conceito presentes na literatura da área da Organização da informação e do conhecimento, com ênfase nas abordagens das Teorias da Classificação, da Terminologia e da Teoria Analítica do Conceito. Para identificar as abordagens dos pesquisadores brasileiros sobre o conceito, desenvolve pesquisa empírica de análise dos periódicos brasileiros online de Ciência da Informação. Através de análise de citações e do conteúdo dos artigos selecionados, foi identificado como principal eixo paradigmático das abordagens, a Teoria Analítica do Conceito, de Dahlberg. A Teoria da Classificação Facetada, de Ranganathan, a Teoria Geral da Terminologia, de Wüster, e as Ontologias, de Guarino, aparecem associadas a Dahlberg nos artigos teórico-metodológicos. Nos artigos teórico-epistemológicos dominam as abordagens comunicativas da terminologia, socioterminológicas, lingüísticas, semânticas e pragmáticas na construção de conceitos. As análises não permitiram comprovar inteiramente a hipótese de partida porque muitos artigos apresentam discussões epistemológicas, teóricas e metodológicas sobre o conceito. Observou-se, no entanto, que muitos artigos adotam os modelos propostos pelas correntes positivistas, de forma acrítica, sem questionar as bases filosóficas e teóricas subjacentes. Considera-se necessário retomar os principais eixos paradigmáticos sobre o conceito para consolidar as pesquisas teórico-epistemológicas da área, inclusive com a elaboração de obras de sistematização dos avanços já alcançados, para uso na formação de profissionais e pesquisadores da área.

Palavras-chave: Conceitos. Organização da informação e do conhecimento. Conceitos e linguagem. Conceitos e filosofia. Conceitos e ciência.

\begin{abstract}
The theoretical approach of the concept, which goes back to the classical philosophy, went through various periods and schools of thought, to reach the contemporary approaches. The concepts are also consolidated research objects in Information and knowledge Organization of area, studied under philosophical influences. This research intended to identify the main lines of theoretical approaches developed in the studies on the concept in Information and Knowledge Organization area. Our hypothesis was that these lines were not sufficiently explained and that new approaches to the concept would contribute to the strengthening of the area. To support the research, the literature on the concept in philosophy and science was examined, discussing also issues such as metaphor and language in the order of the concepts. The approaches on the concept from the perspectives of Foucault, Deleuze and Guattari, Gilles-Gaston Granger, Eleanor Rosch and Vygotsky are also presented. The definitions of the concept in the literature of Information and Knowledge Organization, with emphasis on approaches on Classification, Terminology and Analytic Theory of Concept is also discussed. To identify the approaches of the Brazilian researchers, empirical analysis of online Brazilian journals of Information Science were examined. Through citation and content analysis of selected papers, Analytic Theory of Concept of Dahlberg was identified as a theoretical and methodological paradigm in Information and Knowledge Organization. It was also observed that the Theory of Faceted Classification of Ranganathan, Analytic Theory of Concept of Dahlberg, the General Theory of Terminology of Wüster, and the Ontology of Guarino, are closely associated in the methodological papers. On the other side, in the theoreticalepistemological papers the Communicative Theory of Terminology and Socioterminology are dominant theories. In these papers, linguistics, semantics and pragmatics concepts are pointed. The analysis failed to fully prove the initial hypothesis. In fact, many papers present philosophical, theoretical and methodological questions about the concept. Many papers, however, adopt the model proposed by the positivists, uncritically, without questioning the philosophical and theoretical underpinning. Critical approaches are certainly important to consolidate the theoretical and epistemological research in the area. It is recommend the systematization and publishing of books with the current achievements for use in scientific and professional education.
\end{abstract}

Key-words: Concepts. Organization of information and knowledge. Concepts and language. Concepts and philosophy. Concepts and science. 


\section{SUMÁRIO}

\section{INTRODUÇÃO}

1 OS CONCEITOS NA FILOSOFIA, NA CIÊNCIA E NA LINGUAGEM $\ldots 12$

1.1 Conceitos na filosofia

1.2 Conceitos nas ciências

1.3 Conceitos e linguagem

2 A ORDEM DOS CONCEITOS 27

2.1 Epistemologia da linguagem $\ldots \ldots \ldots \ldots$

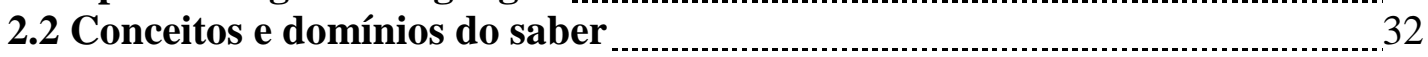

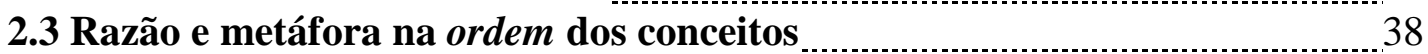

2.4 Ordem dos conceitos

2.5 Foucault e a formação de conceitos $\quad 48$

2.6 Deleuze e Guattari: apenas a filosofia cria conceitos $\ldots$

2.7 Conceitos filosóficos e científicos: Gilles-Gaston Granger _........................ 63

2.8 Natureza dos conceitos nas ciências cognitivas: Eleanor Rosch e Vygotsky ... 72

3 ORDEM DOS CONCEITOS NA ORGANIZAÇÃO DA INFORMAÇÃO E DO CONHECIMENTO 84

3.10 que é um conceito?

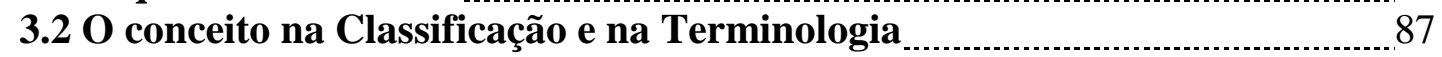

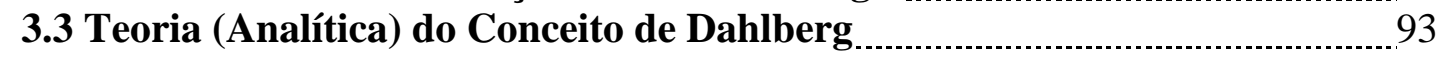

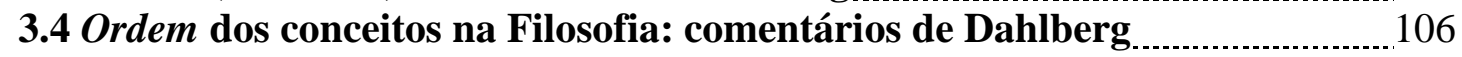

3.5 Retrospectiva crítica do conceito

4 OS CONCEITOS NA ORGANIZAÇÃO DA INFORMAÇÃO E DO CONHECIMENTO: UMA ANÁLISE DE ARTIGOS DE PERIÓDICOS BRASILEIROS 120

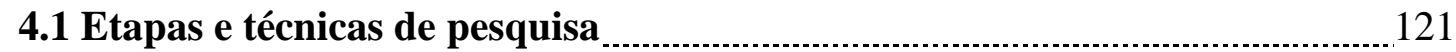

4.1.1 Definição do universo da pesquisa $\ldots 12$

4.1.2 Estratégia de busca $\ldots$

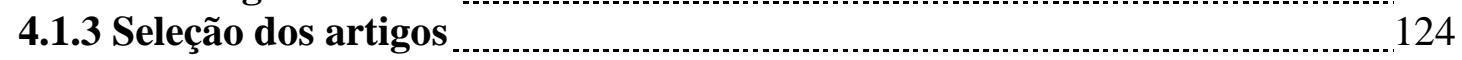

4.2 Análise do Corpus

4.2.1 Padronização dos dados (reformatação) 127

4.2.2 Resultados da Análise de citações $\ldots 130$

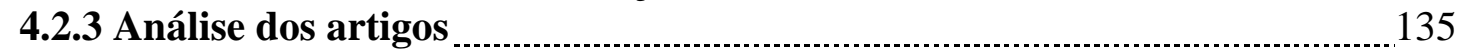

4.3 Discussão dos resultados 179

5 CONSIDERAÇÕES FINAIS

6 BIBLIOGRAFIA 186

7 APÊNDICES 


\section{INTRODUÇÃO}

O pensamento por meio de conceitos surge, segundo Costa (2002), quando o homem se faz a primeira pergunta sobre a existência das coisas no mundo sem recorrer a explicações mitológicas. Sócrates, Platão e, depois, Aristóteles, por exemplo, se perguntavam sobre os conceitos das coisas nos planos real e ideal. Perguntavam pelo conceito de justiça, de verdade, de educação, especialmente Sócrates, buscando na prática do diálogo as características e proposições necessárias e suficientes para configurar um conceito e depois reconstruí-lo em novas argumentações e diálogos. $\mathrm{O}$ pensamento conceitual, surgido na Grécia antiga, passa por todo o período medieval e se afina cada vez mais na modernidade e na contemporaneidade

Desde a introdução das categorias pela lógica aristotélica, passando pela ontologia medieval, pela metafísica e pela lógica moderna, até chegar ao positivismo, à fenomenologia, à hermenêutica e à teoria da ciência, se avolumam os estudos que tomam o conceito como objeto. Contemporaneamente, esses estudos estão presentes na Filosofia, como também nos diferentes campos do saber: na Linguística, na Psicologia, na Educação, nas Ciências cognitivas, na Ciência da informação, entre outros.

Muitos são os pontos de vista sobre o conceito, sendo comuns os embates entre os mais expressivos pensadores. Mas, para Pozzi (1999), a discussão ganhou maior dimensão com o desenvolvimento científico e tecnológico, tendo chamado a atenção da Filosofia, da Filosofia da ciência e da própria Ciência para os problemas relacionados aos termos científicos. Essa discussão é também um imperativo na área da Organização da informação e do conhecimento. Com efeito, a produção de novos conhecimentos e suas aplicações são largamente dependentes de acesso rápido e seguro a informações produzidas anteriormente.

Por outro lado, o acesso à informação, para ser factível, depende de distintas formas de organizá-la por meio da categorização e da classificação. A área da Organização da informação e do conhecimento conquistou relativa autonomia dentro do campo da Ciência da Informação (CINTRA et al., 2002) precisamente ao se dedicar à busca de teorias e ferramentas para aprimorar as formas de armazenamento e recuperação de informação, entendidas estas, como processos que requerem a representação de informação. A idéia de organizar conteúdos informacionais remete, desse modo, à elaboração de métodos e instrumentos para representar informação por meio de conceitos, em particular os instrumentos denominados linguagens 
documentárias e suas variações: sistemas de classificação, taxonomias e ontologias.

\section{O problema da pesquisa}

Os conceitos são objetos de estudo de áreas como a Filosofia, a Lógica, a Lingüística, as Ciências cognitivas, entre outras. Presume-se, a partir daí, que há variações nas abordagens sobre o conceito, segundo o campo em que o objeto é discutido. Mesmo dentro de uma mesma área, como a da Filosofia, por exemplo, as concepções e abordagens sobre o conceito variam de acordo com a corrente teóricoepistemológica considerada. Por outro lado, tendo em vista a importância do conceito nos estudos e nas práticas de Organização do Conhecimento, pode-se indagar:

A) O que é o conceito?

B) Quais são as principais linhas de força teóricas (paradigmas) presentes nas abordagens do conceito, na área da Organização da informação e do conhecimento?

C) Quais são as áreas de conhecimento que têm maior influência nas abordagens sobre o conceito, na área da Organização da informação e do conhecimento?

D) Variações nas abordagens sobre o conceito afetam as metodologias de construção de instrumentos de Organização da informação e do conhecimento?

\section{Hipóteses de trabalho}

Como soluções provisórias para as questões acima, são propostas as seguintes hipóteses:

A) As abordagens sobre o conceito na área da Organização da informação não estão suficientemente explicitadas. Assim, as propostas de operacionalização de conceitos podem estar sendo realizadas de forma irrefletida;

B) As principais linhas de força teóricas (paradigmas) da Organização do Conhecimento, embora não claramente explicitadas, estão sedimentadas no positivismo lógico e na filosofia pragmática da linguagem.

\section{Objetivos}

Com base na contextualização do objeto de pesquisa, dos problemas e das hipóteses de trabalho, podem ser delineados os objetivos da tese: 


\section{Objetivo geral}

Contribuir para a consolidação teórica e metodológica, da área da Organização da informação e do conhecimento, propondo uma abordagem sistemática sobre o conceito.

\section{Objetivos específicos}

A) Identificar as principais linhas de força teóricas e metodológicas sobre os conceitos adotados nas pesquisas sobre a Organização da informação e do conhecimento;

B) Descrever as variações teórico-metodológicas sobre o conceito na área e como elas podem afetar a construção de instrumentos de organização, tratamento e uso da informação.

\section{Metodologia de pesquisa}

A pesquisa, de natureza hipotético-dedutiva, foi desenvolvida como segue:

a) construção de referencial teórico sobre o conceito, com base nas abordagens da filosofia, das ciências, da linguagem, da lógica e da cognição;

b) análise de periódicos nacionais de Ciência da informação, para identificação e seleção de artigos sobre o conceito, produzidos por autores identificados com a área da Organização da informação e do conhecimento;

c) análise crítica das abordagens adotadas pelos pesquisadores brasileiros, com base no referencial teórico construído.

A descrição dos procedimentos metodológicos será apresentada de forma sistemática no capítulo 4 da tese.

\section{Estrutura do trabalho}

A tese é constituída da introdução, onde são apresentadas, em síntese, a descrição dos principais componentes do projeto de tese proposto e a descrição resumida das etapas metodológicas seguidas para alcançar os objetivos propostos e de 5 capítulos.

O capítulo 1 apresenta uma análise dos conceitos em três perspectivas: o conceito na filosofia, o conceito nas ciências e os conceitos e linguagem.

No capítulo 2 há uma análise sobre diversas perspectivas do conceito. Discutemse os princípios de uma epistemologia da linguagem e algumas características dos conceitos nas fronteiras disciplinares e nos limites da razão e da metáfora, apresentando 
o tópico "ordem dos conceitos" sobre as principais classificações dos "seres e dos saberes". No capítulo 2 aprofundam-se as análises sobre a formação e relação dos conceitos, com ênfase nas obras de Foucault; Deleuze e Guattari; Granger e a formação dos conceitos no universo cognitivo, com base em Eleanor Rosch e Vygotsky.

No capítulo 3 são discutidas as concepções sobre o conceito na Organização da informação e do conhecimento, nas Teorias da Classificação e na Terminologia. É analisada a Teoria Analítica do Conceito de Dahlberg e discutidas as suas posições com relação aos conceitos em distintas correntes filosóficas. Apresenta-se uma discussão crítica sobre algumas abordagens do conceito, sendo indicadas as novas perspectivas de pesquisa na área.

O capítulo 4 é dedicado à pesquisa empírica, de análise de artigos de periódicos brasileiros de Ciência da Informação, disponíveis online. A pesquisa empírica subdivide-se em análise de citações e análise de conteúdo dos artigos selecionados.

No capítulos 5 são apresentados e discutidos os principais resultados da pesquisa. No itens 6 e 7 estão, respectivamente, a bibliografia e os apêndices.

A estrutura da tese, portanto, está distribuída em duas partes: a primeira, do capítulo 1 ao 3, fundamentalmente teórica, dá suporte para as discussões da parte empírica, apresentada no capítulo 4 . 


\section{OS CONCEITOS NA FILOSOFIA, NAS CIÊNCIAS E NA LINGUAGEM}

\subsection{Conceitos na filosofia}

Para Shera (1957, p.2), a ciência é formada por duas "ordens" da experiência: “[...] uma é a discriminação direta, imediata da observação, a outra deriva das concepções do homem, do universo." A primeira, a "ordem observante", é dependente das interpretações da segunda, a “ordem conceitual”. Para o autor, a Filosofia (ou Filosofia da Ciência) é responsável por coordenar as duas ordens, expressas em um modo de classificação.

Pensar com conceitos ${ }^{1}$ sempre auxiliou a tarefa de filosofar sobre os significados, sobre o pensamento e sobre o ser. Na concepção de Pozzi (1999), "ter um conceito X" é uma expressão importante para saber se o enfoque está nas palavras, nos pensamentos ou nos objetos e pode "[...] ser interpretada no sentido de saber o significado da palavra $\mathrm{X}$; reconhecendo um $\mathrm{X}$ de todos os não-X; pensando $\mathrm{X}$ quando não está presente; saber $\mathrm{o}$ que é $\mathrm{X}$ e apreender suas características (essenciais, propriedades, universais, etc) [...]" (POZZI, 1999, p.2). Conhecer esses modelos e usos dos conceitos é uma questão fundamental, porém cheia de obstáculos (POZZI, 1999, p.3-5). Não pretendemos, no âmbito desta pesquisa, discutir as diferentes posições filosóficas - tarefa de enorme complexidade e muitas vezes infrutífera, segundo Shera (1957); pretendemos, antes, apresentar algumas abordagens, com o objetivo de traçar um panorama que permita refletir sobre o uso do termo conceito nas teorias e métodos propostos pela área da Organização da informação e do conhecimento.

A primeira questão a ser colocada em um estudo sobre o conceito refere-se à dificuldade de compreender a dimensão tomada por esse objeto ao longo do tempo, como afirma Ferrater Mora:

O termo 'conceito' - e os correspondentes termos em várias línguas: Concept, Begriff, Concetto, etc. - foi usado em acepções muito diversas, equiparando-se às vezes a 'noção', às vezes a 'idéia', às vezes a 'pensamento'. Como cada um destes últimos termos foi empregado também em acepções muito diferentes, nenhuma das equiparações mencionadas é de grande ajuda para se entender o significado ou o uso de 'conceito'. (FERRATER MORA, 2004, p.518).

Acrescenta-se outro problema, também levantado pelo mesmo autor: o termo "conceito" é usado, via de regra, de maneira vaga e generalizada em diversos contextos

\footnotetext{
${ }^{1}$ Sobre o "pensar com conceitos" no plano metodológico, ver Wilson (2005).
} 
e situações. Para contornar o problema, Ferrater Mora (2004) propõe que se tente definir alguns contextos históricos ou teóricos que se apresentem de forma mais precisa. Nesse sentido, afirma que a tradução do logos grego por conceito é insatisfatória, ocorrendo o mesmo com a tradução de logos por "noção", "termo" ou "idéia".

Abbagnano (2007, p.194-195) concorda com a idéia de generalidade do conceito - sendo difícil encontrar opiniões contrárias, especialmente na Filosofia -, que pode incluir qualquer "sinal ou procedimento semântico".

Embora o C. [conceito] seja normalmente indicado por um nome, não é o nome, visto que diferentes nomes podem exprimir o mesmo C. ou diferentes conceitos podem ser indicados, por equívoco, pelo mesmo nome. O C., além disso, não é um elemento simples ou indivisível, mas pode ser constituído por um conjunto de técnicas simbólicas extremamente complexas, como é o caso das teorias científicas que também podem ser chamadas de C. (o C. da relatividade, o C. de evolução etc.). O C. tampouco se refere necessariamente a coisas ou fatos reais, pois pode haver C. de coisas inexistentes ou passadas, cuja existência não é verificável nem tem um sentido específico. Enfim, o alegado caráter de universalidade subjetiva ou validade intersubjetiva do $C$. na realidade é simplesmente a sua comunicabilidade de signo lingüístico: a função primeira e fundamental do C. é a mesma da linguagem: a comunicação. (ABBAGNANO, 2007, p.195).

$\mathrm{Na}$ filosofia clássica, especialmente em Platão e Aristóteles, o conceito era tratado como um "universal" definidor da natureza de uma entidade. Dessa maneira, o conceito tanto podia ser entendido como uma essência ou como uma substância. Em Platão, e posteriormente em Aristóteles, o “[...] 'conceito' já era de algum modo órgão de conhecimento da realidade [...] as formas em que a realidade se distribui e de que 'surge' metafisicamente correspondem aos conceitos que a mente forja - com base na abstração das percepções [...]” (FERRATER MORA, 2004, p.518).

Os escolásticos também fazem uso do termo conceptus. Dentro de uma proposta de classificação, distinguem conceitos formais e objetivos. O exemplo sobre o triângulo, de Ferrater Mora (2004, p.519), ilustra o que é um conceito objetivo e um conceito formal: "[...] o triângulo enquanto expresso pela mente e na mente é um conceito formal, e o próprio triângulo ao qual se refere o conceito formal é um conceito objetivo".

A tendência escolástica em torno dos universais se mantém, em certo sentido, na Idade Média. A problemática era saber até que ponto um conceito era uma essência, uma intenção da alma ou um termo da linguagem (FERRATER MORA, 2004, p.519). 
No período Moderno, os estudos sobre o conceito têm orientação racionalista e empirista:

Entre os autores racionalistas como Descartes ou Leibniz, o conceito, ou a idéia, tem uma acepção 'metafísica' e, como consequência de tal acepção, lhe é dada uma interpretação epistemológica. Entre os autores empiristas, como Locke ou Hume, o conceito ou a idéia costumam ter uma significação psicológica; em todo caso, esses autores procuram ver como se originam os 'conceitos'. Há na vertente empirista, além disso, de Locke a John Stuart Mill, uma propensão nominalista ou, em todo caso, 'conceptualista' (por exemplo, conceptualista em Locke, nominalista em Hume e em John Stuart Mill e, por razões diferentes, em Berkeley). Por esse motivo, é importante em muitos desses autores o estudo da maneira como se 'associam' os conceitos, enquanto idéias que a mente forma com base nas percepções ou perceptos e, em alguns casos, enquanto sendo as próprias 'percepções'. (FERRATER MORA, 2004, p.519).

Para Kant (1987, p.64), há distinção imediata entre sensações e percepções, por um lado, e conceitos, por outro. Mais especificamente, trata-se de estabelecer distinção entre intuição e conceito. $\mathrm{O}$ entendimento é um conhecimento produzido discursivamente mediante conceitos e não por intuição. As intuições fundam-se nas impressões sensíveis e, os conceitos, na faculdade do juízo. Os conceitos são funções que, por sua vez, são ações de "[...] ordenar diversas representações sob uma representação comum" (KANT, 1987, p.64). O conceito, ao contrário da intuição, nunca se refere imediatamente a um objeto, mas à sua representação.

Ainda segundo Ferrater Mora (2004), os conceitos podem ser considerados como convencionais e instrumentais, iguais a significados, como descrições "econômicas" para as operações classificatórias e definitórias, em oposição às interpretações nominalistas e empiristas, distinguidos entre realidade psicológica e validade lógica. São inúmeros, portanto, os posicionamentos filosóficos sobre o conceito (FERRATER MORA, 2004, p.520-521), que podem ser distintos de "objetos" (Frege), distintos de preceitos, mas considerados como algo "percebido" (William James), separados em conceitos "semânticos" e "absolutos" (Carnap) ou ligados ao "idealismo" hegeliano como elementos "últimos de todos os pensamentos" (Pfänder).

Os conceitos podem, ainda, apresentar diferentes características, tais como “compreensão" e "extensão". Também podem ser classificados em "objetivos" e "funcionais", de acordo com a lógica e, de acordo com a ontologia, serem "subordinados" e "coordenados". Existem os conceitos "gerais", como os de gênero e espécie, os conceitos "gerais em outro sentido" como os "plurais", os "universais", os 
"coletivos" e, ainda, os conceitos "abstratos" e "concretos" e os "simples" e "compostos",

Três outros filósofos podem ser citados nas discussões sobre o conceito. O primeiro é Benedetto Croce; o segundo é Hegel; e, o terceiro, o filósofo austríaco Ludwig Wittgenstein.

Segundo Rovighi (2001, p.325), para Croce os conceitos empíricos como "gato", "casa", "rosa" são pseudoconceitos, pois, não são autênticos e não são "suprarepresentativos" (não vão além de suas representações); da mesma forma, os conceitos abstratos, como os matemáticos, não têm autenticidade, pois não são "onirepresentativos" (não exprimem a totalidade da realidade). Croce entende como "conceito puro" o conceito que pode ser universal, aplicado a quase todas as situações, como o de qualidade, quantidade, evolução ou "[...] qualquer pensamento que possa ser concebivelmente aplicado a toda a realidade" (DURANT, 1996, p.430). Baseado no idealismo de Hegel, Croce afirma que os "pseudoconceitos" são obras do Intelecto, enquanto que os "conceitos puros" são obras da Razão. (REALI; ANTISERI, 2003, p.530). Portanto, os verdadeiros conceitos, os conceitos "universais-concretos", são poucos e devem estar presentes em toda a realidade. São, desse modo, metaconceitos de natureza categorial.

Reali e Antiseri (2003, p.136) afirmam que na lógica ${ }^{3}$ de Hegel o conceito está acima do intelecto, em um ponto de vista superior da razão, em um novo plano. De acordo com Hegel (apud REALI; ANTISERI, 2003, p.137) o conceito não é abstrato nem vazio, mas concreto e absoluto e, ao mesmo tempo, contém em si o ser e a essência. Os três níveis que compõem a lógica de Hegel são o ser, a essência e o conceito, divididos em categorias (REALI; ANTISERI, 2003, p.128-129). Logo, o conceito incorpora os outros dois níveis e suas categorias. Segundo Châtelet (1995, p.71), "O domínio do conceito é aquele onde as oposições entre o imediato e o mediato, entre o objecto e o sujeito, entre o finito e o infinito, entre o em si e o para si se mantêm e, ao mesmo tempo, se anulam". Colocado em um patamar de extrema contemplação do sujeito pela razão, o conceito em Hegel é, ainda segundo Reali e Antiseri (2003, p.138),

\footnotetext{
${ }^{2}$ Para uma síntese específica sobre filósofos, conceitos e posições contrastantes, ver Pozzi (1999).

${ }^{3}$ É importante dizer que, para Hegel, a lógica "[...] era uma ontologia e se identificava com a metafísica." (ROVIGHI, 2001, p.322).
} 
“[...] o nome mais rico e mais adequado (até este momento do processo lógico) para expressar o Absoluto [...]".

Longe dos problemas do ser, da essência e do "absoluto", Wittgenstein apresenta uma forma diferente de pensar os conceitos. Na perspectiva da Filosofia da linguagem, ao abordar o conceito de "jogo", afirma que este apresenta "contornos imprecisos" e se questiona: “[...] um conceito impreciso é, por acaso, um conceito?”. (WITTGENSTEIN, 2005, p.54-55, §71). A analogia proposta por Wittgenstein relaciona um retrato nítido e um retrato desfocado.

Uma fotografia desfocada é, por acaso, o retrato de uma pessoa? Bem, podese substituir sempre com vantagem um retrato desfocado por um nítido? Freqüentes vezes não é o retrato desfocado precisamente aquilo de que mais precisamos?

Frege compara o conceito a uma região, afirmando: uma região delimitada sem clareza não pode, absolutamente, ser chamada de região. Isso significa que não podemos fazer nada com ela. - Mas não tem sentido dizer: 'Detenhase mais ou menos aqui'? Imagine que eu estivesse com uma outra pessoa em um lugar e dissesse isto. Nisso, nem ao menos traçarei algum limite, mas farei um movimento indicativo talvez com a mão, - como se lhe mostrasse um determinado ponto. E é precisamente assim que se explica o que é um jogo. Dá-se exemplos e pretende-se que eles sejam entendidos num certo sentido. - Mas com esta expressão não tenho em mente: nestes exemplos ele deve ver o comum, aquilo que - por uma razão qualquer - não consegui trazer à fala. Mas: ele deve empregar estes exemplos apenas num determinado modo. A exemplificação não é aqui um meio indireto de explicação, - na falta de um melhor. Pois, toda explicação geral também pode ser mal entendida. É assim que jogamos o jogo. (É o jogo de linguagem que tenho em mente com a palavra 'jogo'.).

Para Wittgenstein (2005, p.203, §569), a linguagem e os conceitos são "instrumentos". Seu interesse fica mais claro quando afirma que "Os conceitos nos conduzem às investigações. Eles são a expressão de nosso interesse, e conduzem o nosso interesse" (WITTGENSTEIN, 2005, p.203, §570).

Mas, no prefácio da obra Investigações Filosóficas (WITTGENSTEIN, 2005, p.11) observa-se que sua preocupação é o “[...] conceito de significado, de compreensão, de proposição, de lógica [...]".

Wittgenstein elabora, assim, um aspecto fundamental da Filosofia pragmática da linguagem: não são os fenômenos que devem ser analisados, mas sim os conceitos dos fenômenos, o uso das palavras.

Não analisamos um fenômeno (p. ex. o pensar), mas um conceito (p. ex. o conceito de pensar), portanto o emprego de uma palavra. Assim, pode parecer como se o que praticamos seja nominalismo. Os nominalistas cometem o erro de interpretar todas as palavras como nomes, portanto, de 
não descrever realmente o seu emprego, mas sim de dar, por assim dizer, apenas uma indicação em papel de uma tal descrição. (WITTGENSTEIN, 2005, p.160, §383).

Nessa medida, um conceito é aprendido com a linguagem, no uso da linguagem, e não com o fenômeno: "Você aprendeu o conceito de 'dor' com a linguagem" (WITTGENSTEIN, 2005, p.160, §384). O indivíduo aprende que a sensação estranha que sente em seu corpo é chamada "dor"; por outro lado, também aprende que o conceito "dor" pode ser usado em diversos sentidos, para expressar a dor de uma saudade, a dor de um amor, a dor de ver as pessoas sofrendo, etc.

Se é possível explicar a formação do conceito a partir de fatos naturais, então, ao invés da gramática, não nos deveria interessar aquilo que na natureza constitui a sua base? - Interessa-nos, sem dúvida, também a analogia de conceitos com fatos naturais muito genéricos. (Com aqueles que, por causa da sua generalidade, normalmente não se fazem notar.) Mas nosso interesse não recai sobre as possíveis causas da formação do conceito; nós não fazemos ciência natural, nem tampouco história natural, - pois para nossos fins podemos inventar também coisas histórico-naturais.

Não digo: se tais e tais fatos naturais fossem diferentes, as pessoas teriam conceitos diferentes (no sentido de uma hipótese). Mas: Quem acredita que certos conceitos são simplesmente os conceitos corretos, alguém que tivesse outros conceitos não compreenderia justamente algo que nós compreendemos, - ele pode representar-se certos fatos naturais bem genéricos de modo diferente do que estamos acostumados, e outras formações do conceito diferentes das habituais vão tornar-se compreensíveis para ele.

Compare um conceito com um estilo de pintura: Será que somente nosso estilo de pintura é arbitrário? Podemos escolher um conforme o gosto? (p. ex.: o estilo dos egípcios). Ou trata-se aqui apenas de bonito e feio? (WITTGENSTEIN, 2005, p.295).

"Um conceito se impõe", afirma Wittgenstein (2005, p.267). Um conceito não depende da robustez de um único fio, mas da quantidade de fibras traçadas nele. "[...] a robustez do fio não consiste em que uma fibra qualquer perpasse toda sua extensão, mas em que muitas fibras se sobreponham umas às outras" (WITTGENSTEIN, 2005, p.52, $\S 67)$.

Questão semelhante é levantada por Cassirer (2003, p.42-43) ao se questionar sobre a existência das "notas", dos traços característicos do conceito antes da própria linguagem e antes mesmo de sua denominação.

Wittgenstein não parece estar preocupado com os nomes das coisas, nem com as definições das palavras. Não está interessado com os atributos suficientes e necessários, nem mesmo com as essências e características dos conceitos; ao contrário, seu interesse está em saber como é possível o uso da linguagem, como os conceitos acontecem e 
como podem se afirmar e fazer sentido em um sistema. No universo da Filosofia pragmática da linguagem de Wittgenstein, o processo de significação (dos conceitos) é sempre contextual.

\subsection{Conceitos nas ciências}

Na obra Classificação em Arqueologia, Dunnell (2007, p.51-52) afirma que o conceito é usado para "[...] cobrir uma ampla variedade de coisas, indo desde um termo extravagante aplicado a palavras que se queira dignificar por uma razão qualquer até simples idéias ou noções". Para esse autor, os conceitos são necessários, não apenas para categorizar "classes específicas de fenômenos" ou para a divisão em gênero e espécie, mas, também, para demonstrar suas relações.

Nas disciplinas acadêmicas, os conceitos são usados para isolar objetos de estudo. Nesse caso, o principal objetivo do "[...] conceito na investigação científica consiste precisamente em identificar as unidades em discussão". Secundariamente, os conceitos "[...] são empregados para discutir operações com dados e para discutir a teoria e o método nos quais as operações se baseiam”. Dunnell (2007, p.52) ainda afirma que os conceitos são "palavras" que ocorrem de maneiras diferentes na linguagem coloquial e na linguagem científica. Observa, ainda, que:

Uma última coisa a notar com relação aos conceitos: em todos os casos eles são parte do domínio ideativo. Somente as palavras que encarnam os conceitos, faladas ou escritas, podem ser fenomenológicas. É com esses conceitos que a ciência opera, comunicando suas categorias e as operações nelas realizadas, razão pela qual os conceitos constituem a pedra angular na compreensão da natureza de qualquer disciplina e sua investigação particular (DUNNELL, 2007, p.53).

A caracterização dos $\operatorname{conceitos}^{4}$ na ciência supõe, via de regra, o uso da linguagem dentro de limites definidos, sem ambiguidades. Para Köche (2002, p.115), a linguagem científica "[...] deve ser específica e delimitada. Ela tenta representar a realidade através de uma simbologia que deverá ser exata, sensível e consensual (intersubjetiva) e representar o mais exatamente possível os fenômenos da realidade".

\footnotetext{
${ }^{4} \mathrm{Na}$ ciência, os conceitos criados intencionalmente, com significados específicos, que podem ser "operados" chamam-se construtos. (KÖCHE, 2002, p.115). Outro ponto que não será abordado no texto, mas que pode ser verificado em Fourez (1995), é a diferença entre noção, idéia e conceito. Para Fourez (1995, p.228-233), a noção implica algo vago e individual. Uma pessoa tem a noção de algo, tem uma vaga compreensão do que significa uma família, por exemplo. A idéia estaria ligada a algo coletivo e mais geral, "universal". A idéia de natureza e de Deus, por exemplo. O conceito é uma noção mais precisa, desenvolvida dentro de algum paradigma; por exemplo, o conceito de família na sociologia, de natureza na biologia e de Deus na antropologia ou na teologia.
} 
A linguagem natural era a linguagem da ciência tanto do período grego quanto do medieval. Esse modo de produção de conceitos foi substituído com a ciência moderna 5 . De acordo com Gil (1979, p.166) a "[...] ciência moderna forma-se pela derrocada do modo 'grego' de produção dos conceitos [...]”. Nessa ótica, Gil (1979, p.165. Grifos do autor) afirma que "O modo de produção da ciência é em primeiro lugar um modo de produção de conceitos [...]".

Bachelard (1978), no livro A Filosofia do Não, faz a análise epistemológica do conceito científico ${ }^{6}$ sob diversas perspectivas.

É evidente que os conceitos científicos não atingiram todos o mesmo estádio de maturidade; muitos permanecem ainda implicados num realismo mais ou menos ingênuo; muitos são ainda definidos na orgulhosa modéstia do positivismo; o que faz com que, examinada nos seus elementos, a filosofia do espírito científico não possa ser uma filosofia homogênea. (BACHELARD, 1978, p.11).

Pode-se lembrar, aqui, por analogia, o conceito de informação na Ciência da Informação, muitas vezes discutido na tentativa de dimensionar e consolidar um objeto de pesquisa da área. Outras vezes, a própria maturidade científica da Ciência da Informação foi questionada devido à dinâmica e heterogeneidade do conceito e das formas de apresentação e análise do objeto.

Segundo Bachelard, é mais importante para a ciência analisar o progresso dos conceitos científicos do que a filosofia analisar o progresso dos conceitos filosóficos. De acordo com Bachelard (1978, p.12), o conceito de progresso filosófico

É um conceito que tem pouco significado em filosofia pura. Não caberia na cabeça de nenhum filósofo dizer que Leibniz estava adiantado em relação a Descartes, Kant adiantado em relação a Platão. Mas o sentido da evolução filosófica dos conceitos científicos é tão claro que se torna necessário concluir que o conhecimento científico ordena a própria filosofia. $\mathrm{O}$ pensamento científico fornece, pois, um princípio para a classificação das filosofias e para o estudo do progresso da razão.

Bachelard desconfia dos conceitos que não sofreram discussões, que não foram "dialetizados".

Dever-se-ia, pois, desconfiar sempre de um conceito que não tivesse ainda sido dialetizado. O que impede a sua dialetização é uma sobrecarga do seu

\footnotetext{
${ }^{5}$ Como mencionado na introdução, o conhecimento ocidental tem sua forma inicial traçada pela mitologia grega. Símbolos e metáforas eram usados para explicar as coisas da natureza e do homem. A racionalidade moderna substitui símbolos e metáforas pelo conceito. O conceito é caracterizado por um certo tipo de circularidade ausente nas metáforas mitológicas.

${ }^{6}$ Este não é o foco principal da obra de Bachelard (1978), mas é o ponto destacado para análise. A Filosofia do não de Bachelard, como afirma Paiva (2005, p.29 e segs.), é uma "recusa dos pontos fixos na ciência".
} 
conteúdo. Esta sobrecarga impede o conceito de ser delicadamente sensível a todas as variações das condições em que ele assume as suas justas funções. Atribui-se seguramente demasiado significado a esse conceito, dado que nunca é pensado formalmente. Mas se se lhe atribui demasiado significado, é de temer que dois espíritos diferentes não lhe atribuam o mesmo significado. Daqui resultam as profundas perturbações semânticas que impedem a compreensão recíproca dos homens do nosso tempo. Sofremos de uma incapacidade de mobilizar o nosso pensamento. Para termos alguma garantia de termos a mesma opinião acerca de uma idéia particular, é preciso pelo menos que tenhamos tido sobre ela opiniões diferentes. Se dois homens se querem entender verdadeiramente, têm primeiro que se contradizer. A verdade é filha da discussão e não filha da simpatia. (BACHELARD, 1978, p.81. Grifos do autor).

Mesmo considerando que os conceitos passam por um processo "fisiológico", funcional e intensional, que lhes permitam, de certa forma, atingir "pontos fixos do pensamento", para Bachelard (2004, p.23), no Ensaio sobre o Conhecimento Aproximado, tal condição modifica-se ao se estudar as aplicações do conceito, pois, “[...] eles entram de novo em movimento quando se quer combiná-los ou simplesmente analisá-los, ou seja, quando se quer servir-se deles".

Já foi visto anteriormente, com Gil (1979), que a ciência se produz por meio de conceitos. Bachelard (2004, p.23), por sua vez, afirma que o conceito é um "elemento" de construção e só tem sentido na própria construção, não podendo ele ser nem estar isolado. O pensamento depende da capacidade de relacionar conceitos e não de isolálos. “Apresentar um conceito isolado não é pensar" (BACHELARD, 2004, p.28).

A posição de Bachelard é anti-determinista. Desse modo, não vê nas posições extremas de sínteses racionalistas, positivistas ou empiristas, nenhum fator vinculado à construção do conhecimento. Não por acaso, as duas obras citadas de Bachelard chamam-se A filosofia do não e Ensaio sobre o conhecimento aproximado. Suas posições vão desde a crítica às definições ${ }^{7}$, por considerar que elas nada demonstram e apenas servem para fixar uma linguagem (BACHELARD, 2004, p.26), até o consentimento de que o conceito possui características suficientes para reconhecer um objeto, mas elas seriam o esforço mínimo diante da multiplicidade que poderia ser alcançada pelo conceito no "espírito" (BACHELARD, 2004, p.27).

A posição anti-determinista assumida por Bachelard (2004; 1978), sobre a síntese positivista, contrasta com as posições positivistas e normativas defendidas pela Teoria Geral da Terminologia (GALINSKI; BUDIN, 1998, p.15; CABRÉ, 2000, p.109), de

\footnotetext{
${ }^{7}$ Alguns comentários sobre as críticas às definições e ao "operacionismo" na ciência podem ser encontrados em Köche (2002, p.118) e em Fourez (1995, p.46).
} 
Wüster, e pela Teoria Analítica do Conceito, de Dahlberg. Em síntese, contrastes deste tipo foram acima observados na filosofia e agora na ciência. Por outro lado, tanto na filosofia quanto na ciência contemporânea parece haver maior preocupação com a linguagem e seu uso na construção de conceitos e na dinâmica paradigmática.

\subsection{Conceitos e linguagem}

A Filosofia e as Ciências dão grande importância para a linguagem, especialmente em sua relação com o conceito. Para Hjelmslev (2006, p.2) “A linguagem, como sistema de signos, devia fornecer a chave do sistema conceitual e a da natureza psíquica do homem”. Bachelard (2004, p.28), por sua vez, afirma que “O pensamento só começa com a linguagem, é contemporâneo da junção dos conceitos”. E, para Cassirer (2003, p.51), “[...] a linguagem nunca designa simplesmente os objetos como tais, mas sempre conceitos formados pela atividade espontânea do espírito [...]”.

O conhecimento é matéria prima para o pensar. Quanto maior o conhecimento, maior a capacidade de problematizar e, quanto maior a capacidade de problematizar, mais se pensa e, provavelmente, mais se produz conhecimento. Para Aristóteles o conhecimento é a capacidade de formar conceitos e quanto maior a quantidade de conceitos de que um homem dispõe, maior será a sua sabedoria (ALVARENGA, 2001). Contemporaneamente, pode-se dizer que quanto melhor for o uso dos conceitos, outros conceitos se formarão e maior será o conhecimento acumulado - o que não significa que tais processos sejam inequívocos em sua natureza; é provável que no uso de conceitos, outros conceitos se formarão, assim como é provável que quanto maior o número de conceitos, maior será o conhecimento.

O homem faz uso da linguagem para expressar o pensamento, cujo produto é o conhecimento. O sujeito cognitivo conhece algo pela ação da linguagem (TÁLAMO, 2004, p.2). A linguagem, segundo González de Gómez (1993, p.219), é instrumento de intermediação cognitiva e comunicacional. Segundo Tálamo (2004, p.4), é no plano da linguagem que coisas e idéias se agregam:

[...] a produção de linguagem e a produção de conhecimento são processos associados reciprocamente. De modo preciso, considerando-se que a informação é troca com o mundo e o conhecimento sua apropriação, organização e articulação, tem-se que a produção da linguagem e a produção do conhecimento são processos solidários que mantém relação de pressuposição recíproca.

Isso não significa, porém, que a linguagem seja porta-voz de conhecimentos 
claros e precisos, que o pensamento, através do uso correto da linguagem, ocorra de forma inequívoca. Segundo Gardner (2003, p.370), Wittgenstein

[...] via a linguagem como um conjunto frouxo e fragmentário de elementos e como meio de comunicação necessário entre indivíduos, mas como propenso a obscurecer tanto quanto a esclarecer, porque ela é a teia através da qual todas as outras experiências passam necessariamente.

Cintra et al (2002, p.26) afirmam, com base em Kristeva (1969) ${ }^{8}$, que a linguagem passou a ser "[...] tomada como chave de acesso do homem moderno às leis do funcionamento social [...]" depois de constituir-se em um objeto científico. Decorre daí que ao se considerar a linguagem no "funcionamento social" não se pode colocá-la, unicamente, em relação de dependência com o pensamento. Os conceitos produzidos/construídos/criados na linguagem necessitam de um universo representacional onde possam ser transmitidos, significados e re-significados.

$\mathrm{Na}$ perspectiva adotada neste trabalho, afirma-se que os conceitos são os principais referenciais para a construção de representações e, para realizarem sua função, dependem da linguagem, pois, como diz Chaumier (1973, p.50) "Qualquer conceito é expresso numa linguagem [...]".

Em certo sentido, os pensadores clássicos e modernos fizeram uso da linguagem para construir suas teorias, filosofias e sistemas, mas não a tomaram, de forma explícita, como objeto de estudo. As exceções talvez fiquem, dentre outras, por conta de Santo Agostinho (354-430), que analisou, baseado no pensamento platônico, aristotélico e estóico, "a natureza do signo e do processo de comunicação" (MARCONDES, 2001, p.111) e Humboldt (1767-1835), considerado por Reale e Antiseri (2003, p.387) como "o iniciador da lingüística moderna". Por outro lado, é apenas no início do século XX, com Saussure e Wittgenstein (WEEDWOOD, 2005; ARAÚJO, 2004; KRISTEVA, 1999), que os estudos sobre a linguagem adquirem maior importância e tornam-se mais sistemáticos.

De acordo com Cintra et al (2002, p.26) "A linguagem, enquanto objeto de reflexão, perde-se no tempo; entretanto, enquanto objeto de uma ciência, é relativamente recente". Através de um certo tipo de paradigma da linguagem, a segunda metade do século XX foi palco do surgimento de uma série de novas abordagens sobre a linguagem.

\footnotetext{
${ }^{8}$ Em nossas referências Kristeva (1999).
} 
A importância dada à linguagem, na Ciência da Informação, é também digna de nota. Em seu interior, a área da Organização da informação e do conhecimento promoveu estudos sistemáticos sobre a linguagem, suscitados pelo interesse pelos processos de mediação da informação, como já referido na Introdução desta tese. A semântica e a pragmática, como também o estruturalismo, estão na base de muitos estudos sobre a linguagem. Por outro lado, devido à proliferação de estudos sobre a linguagem, nos últimos anos, fica difícil estabelecer referenciais teóricos precisos. Tal proliferação se fundamenta em um fecundo mosaico teórico, que vai de Saussure a Apel, passando por Wittgenstein, Peirce, Quine, Foucault, Bakhtin, Searle e Chomsky.

Se há preocupação com a mediação da informação e com o seu uso em sociedade, os estudos sobre a linguagem são passagem obrigatória. De fato, as pesquisas sobre o tratamento e a organização de sistemas de recuperação da informação incorporam desde teorias cognitivas sobre a representação até a construção de ontologias e as aplicações da lógica e da lingüística ao ambiente computacional (INGWERSEN, 2002; SOWA, 2000).

Falar de usuário ou de usos da informação em sociedade é falar também dos padrões de uso da linguagem em um ambiente epistêmico determinado. Implica, ainda, entender os "mecanismos" de construção da linguagem e sua função no organismo social e epistêmico, incluindo aí tanto os grupos especializados quanto os nãoespecializados, e as relações que os unem em redes discursivas. Os processos discursivos são importantes, pois demandam acordos e contratos comunicacionais (GONZÁLEZ DE GÓMEZ, 1999; 2007), além do conhecimento compartilhado das regras de uso da linguagem.

Kuhn (2001, p.69; 2006) estabeleceu importantes analogias entre os discursos da ciência, os jogos de linguagem e a incomensurabilidade dos paradigmas ${ }^{9}$. Nas análises sobre a construção do conhecimento científico, atribui aos jogos discursivos a

\footnotetext{
${ }^{9}$ Para González de Gómez (2005), Kuhn é um "pós-empiricista”, que,

[...] atuando no campo da História das Ciências, em sincronia com a teoria dos jogos da linguagem de Wittgenstein, elabora o conceito de 'paradigma', no qual leva a suas últimas consequências os efeitos epistêmicos das especialidades, afirmando o caráter local e contextual dos discursos e práticas científicas. Para Kuhn, diferentes matrizes disciplinares agem como diferentes culturas ou subculturas, incomensuráveis em seus modos de olhar e de nomear suas objetivações construídas, de modo que não se poderia manter a diferenciação entre conceitos teóricos e conceitos empíricos. Entre um e outro paradigma, ou entre um e outro jogo de linguagem não há tradução, mas 'conversão'. (GONZÁLEZ DE GÓMEZ, 2005, p.19).
} 
responsabilidade pela manutenção de um paradigma em uma comunidade científica. A idéia de jogos, nesse contexto, aproxima-se da noção de uso, regras e jogos de linguagem wittgensteinianos (LORENZANO, 2000; CONDÉ, 2004; OLIVEIRA; CONDÉ, 2002; SILVA, 1997).

Os jogos de linguagem ocorrem no uso da linguagem, ou seja, os sentidos expressos pelos conceitos encadeados na linguagem não são comensuráveis, não ocorrem a priori. Assim, se existe uma forma de incomensurabilidade dos paradigmas e da linguagem, não há razão para se negar a incomensurabilidade dos conceitos.

[...] los 'juegos de lenguage' pueden expresar muchas formas de vida, sin que por un lado haya alguna forma de vida o de lenguage que sintetize las otras, que hable por las otras, y sin que, por el contrario, ellas sean incomensurables: lo que las entrelaza no son, en fin, los a priori de una máquina lógica natural y genérica, mas la comunidad de las posibilidade de acción bajo las condiciones de la intersubjetividad comunicativa. (GONZÁLEZ DE GÓMEZ, 1996, p.49. Grifo da autora).

Nesse sentido, a influência da filosofia da linguagem do segundo Wittgenstein nos estudos da ciência levaria, segundo González de Gómez (2004, p.63), “[...] Kuhn a afirmar a impossibilidade de uma experiência neutra e a incomensurabilidade das linguagens e das teorias científicas”.

Os jogos de linguagem identificam-se com a realidade discursiva construída pelo indivíduo em sua coletividade. Conhecer as regras de uso da linguagem e, principalmente, saber que existem regras pode evitar a adoção de critérios universalizantes e uniformes, reforçando-se a idéia de que o conhecimento e a informação, para terem fluxo adequado, devem ser organizados para recepção por comunidades discursivas.

A idéia de que a linguagem é um paradigma do campo da organização e comunicação da informação fundamenta-se na hipótese de que o desenvolvimento científico ocorre na linguagem. Segundo Cintra et al (2002, p.38) todo “[...] conhecimento técnico-científico desdobra-se num universo de linguagem". Assim, para ser apropriado adequadamente, ele deve ser expresso em linguagem compreendida e aceita por uma coletividade. A recepção configura-se, nessa medida, como ato público, em linguagem adequada (OLIVEIRA, 1993, p.177). Também para Granger (1994, p.51), “Toda ciência se produz numa linguagem [...]” e só pode existir ciência se ela for expressa por um sistema simbólico. Por outro lado, as ciências não podem ser reduzidas 
simplesmente a um sistema de símbolos, mesmo diante de sua relação "essencial" com a linguagem (GRANGER, 1994, p.56-57)

Voltando aos paradigmas, uma observação ainda pode ser feita. Kuhn (2001), ao referir-se a eles, mesmo diante de todos os seus possíveis significados conceituais ou definições ${ }^{10}$, tinha em mente, possivelmente, algo que realmente ditasse as "regras do jogo" e que servisse de modelo. Assim, um paradigma não poderia ser dividido em paradigmas emergenciais, simultâneos ou emergentes. Um paradigma deveria dominar um ou vários campos do conhecimento, dando novos rumos ao desenvolvimento científico. Isso significa que não basta ter fortes argumentos, basear-se em experimentos e experiências ou ter a anuência da comunidade científica. É necessário ter tudo isso incondicionalmente voltado a um único paradigma.

Por outro lado, os paradigmas, apesar de serem únicos, são constituídos por diversas “fibras" (WITTGENSTEIN, 2005, p.52, §67) e não por um único fio. Seguindo a metáfora, é a variedade e, ao mesmo, a similaridade de características dessas fibras que permite a realização de ações coletivas e comunicativas dentro de um paradigma.

Para Kuhn, segundo González de Gómez (1999, p.23), os paradigmas não são "negociáveis". Nesse caso, portanto, havendo um paradigma dominante, outros paradigmas desenvolvem-se em ambientes paralelos de menor expressão.

Os chamados paradigmas dominantes não são paradigmas totalitários ou dogmáticos. Ao contrário, são paradigmas que se destacam dentro das comunidades científicas, sendo aceitos e modificados por elas - são processos que se encaixam na premissa do indeterminismo de Bachelard (1978, p.140) em oposição ao determinismo de ordem fundamental e arbitrário.

Peirce (1989, p.53), no texto “A ética da terminologia”, afirma que a “[...] trama e urdidura de todo pensamento e pesquisa é constituída por símbolos, e que a vida do pensamento e da ciência é inerente a símbolos [...]", porém lembra que a linguagem correta é importante para um pensamento correto, constituindo uma essência e não uma totalidade. Outro ponto importante, abordado por Peirce, é o de resistir à arbitrariedade nos assuntos científicos, principalmente com relação aos termos e notações. Afirma ser

\footnotetext{
${ }^{10}$ Masterman (1979, p.72-108) apresenta mais de vinte maneiras (“sentidos”) pelas quais Kuhn emprega o termo paradigma.
} 
necessário um acordo entre "colaboradores" sobre o uso de termos e símbolos, de modo a reduzir o número de "sistemas de expressão a serem apreendidos".

Portanto, embora os padrões sejam necessários, eles não podem ser congelados. $\mathrm{O}$ universo discursivo ficaria reduzido a conjuntos de proposições por correspondência biunívoca (GONZÁLEZ DE GÓMEZ, 2004, p.63), porém, ao serem estabelecidos por acordos, a linguagem se tornaria mais clara, sem ambigüidades, imune, em larga medida, a interpretações inadequadas.

Para Pozzi (2000, p.7), por outro lado, a relação "biunívoca” entre termo e conceito não é possível na maioria dos casos. Tentar eliminar os fenômenos naturais da língua, como a homonímia, a sinonímia e a polissemia, é difícil, mesmo nas línguas de especialidade. A autora, em conformidade com a Teoria Comunicativa da Terminologia, afirma que "Los términos, como unidades de comunicación especializada son un subconjunto de la lengua natural y como tal heredan el comportamiento de la misma." (POZZI, 2000, p.7). A relação biunívoca rebaixaria a linguagem ao plano do nãocontraditório, perdendo, dessa forma, toda a sua virtude persuasiva e riqueza metafórica (RICOEUR, 2000); por outro lado, seria exposta com maior precisão, eliminando expressões desnecessárias que, em tese, não fazem sentido. 


\section{A ORDEM DOS CONCEITOS}

\subsection{Epistemologia da linguagem}

No universo das relações entre pensamento e realidade, no mundo ocidental, as relações acontecem e se modificam em três etapas: a ontológica, onde a “[...] excelência do conhecer não passa pelo representar. O solo do conhecimento é ontológico [...]" base do pensamento grego, especialmente o platônico; a gnosiológica, na qual “[...] conhecer é representar, e o mundo só é enquanto é representado. O solo do conhecimento é a consciência." - base do pensamento moderno, racionalista e empirista (ou empiricista); e a semiótica, quando "[...] o representado, produto do conhecimento em sua investidura semiótica, manifesta-se como autônomo, independente do sujeito e do objeto do conhecimento.", dessa maneira, “[...] o solo do conhecimento é a linguagem, sistemas de significados ou matéria sinalética." - base do pensamento contemporâneo, especialmente os fundamentados nas ciências da linguagem. (GONZÁLEZ DE GÓMEZ, 1993, p.218).

A linguagem, segundo Hjelmslev (2006, p.2), é um “fio condutor", é um meio e não um fim. É através da linguagem que a realidade se apresenta ao ser humano. Ela não cria a realidade, mas, como diria Benveniste (2005, p.26), a representa. Para Benveniste, a realidade é representada e transmitida por um emissor, através da linguagem, a um receptor que a recria.

Partindo da pergunta "O que é linguagem?”, Apel (2000, p.375) indica que, até o século XX, não se tinha “[...] uma consciência tão clara de que a palavra 'linguagem' aponta para um problema de fundamentos da ciência e da filosofia [...]" e de que ela “[...] tornou-se uma preocupação comum a quase todas as escolas e disciplinas (e possivelmente a única preocupação que elas todas têm em comum)”. Para Granger (1994, p.51), a diversidade das formas de conhecimento científico se revela, realmente, no uso que a ciência faz da linguagem e "[...] toda ciência se produz numa linguagem $[\ldots] "$.

Os estudos sobre a linguagem, segundo Apel, derivam dos estudos da consciência. Para ele, chegou-se “[...] ao consenso de que em nosso século a ocupação do filósofo com a própria consciência, algo característico da Idade Moderna, deu lugar, mais recentemente, à ocupação do filósofo com a linguagem" (APEL, 2000, p.353). Para ele, a Filosofia da Linguagem "parece" ter vindo 
[...] ocupar o lugar da epistemologia tradicional - a filosofia da linguagem não como tematização do objeto linguagem entre outros tantos objetos possíveis da cognição, mas sim como reflexão sobre as condições de possibilidade lingüísticas da cognição. (APEL, 2005, p.164. Grifos do autor)

Ainda segundo o autor, constata-se que atualmente, há uma "[...] transição da epistemologia para a análise lingüística” (APEL, 2005, p.164). Para Rorty (1994, p.26) não há uma "sucessão" da epistemologia para a filosofia da linguagem, mas um reposicionamento diante de questões que a epistemologia não tentou fazer ou, se as fez, não as respondeu.

Então, parecem justificadas as referência aos estudos epistemológicos no campo da Ciência da Informação como atividades que procuram analisar como esse mesmo conhecimento foi representado por meio da linguagem e dos $\operatorname{conceitos}^{11}$ e não apenas como atividades que vasculham seus itinerários na construção do conhecimento. De fato, é possível observar que em alguns campos da Ciência da Informação classicamente sedimentados em princípios e atividades de organização e operacionalização de termos e conceitos em hierarquias e listas - são produzidas novas formas de usar e dizer conceitos por meio ou na linguagem.

São visíveis a importância e o impacto que a linguagem, como sistema de representação e de comunicação, assume no trajeto que vai do evento, como acontecimento, até a sua divulgação, como enunciado - no interior do qual o conceito tem existência preponderante ${ }^{12}$.

Se a linguagem for tomada como elemento essencial e/ou único na construção do

\footnotetext{
${ }^{11}$ Os conceitos de ontologia e taxonomia, por exemplo, apresentam definições e características peculiares em Filosofia, Informática, Arqueologia e Ciência da Informação. (LIMA-MARQUES, 2006; ALMEIDA; BAX, 2003). Em resumo, isso significa que, além de uma definição que carrega características distintas de um mesmo conceito, a forma de apresentação desse conceito em um ambiente de linguagem especializada, no caso a linguagem da Ciência da Informação, também seguirá algumas possíveis regras de uso em suas áreas de domínio. O mesmo exemplo pode ser estendido para o conceito de conceito na Terminologia, na Teoria da Classificação e na Teoria Analítica do Conceito. No âmbito metodológico e teórico-epistemológico sobre os conceitos também destacamos a tese de Rabello (2009) sobre o conceito de documento na Ciência da Informação e o artigo de Capurro e Hjorland (2007) sobre o conceito de informação.

${ }^{12}$ Lembra-se o triângulo semiótico de Lyons (1979) para ilustrar a importância do conceito no universo da enunciação.
}

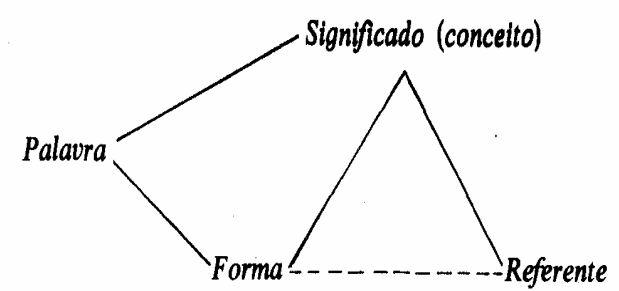

Fonte: Lyons (1979, p.430).
Figura 1. Triângulo semiótico. 
conhecimento, a epistemologia, como teoria, história e ciência do conhecimento, perde ou tem sua função deslocada. Não se defende aqui a tese de que "tudo" é linguagem, pois, esta é uma questão de cunho filosófico, lingüístico e cognitivo, que não poderia ser discutida nos limites desta tese (para maiores discussões, ver Wolf (1999) e Pinker (2008, p.111-178)). Por outro lado, dentro dos objetivos traçados, defende-se que a linguagem, como local e veículo de acontecimento do discurso (por meio de espaços de enunciação (GUIMARÃES, 2002)), é produto e produtora do sujeito do conhecimento ou sujeito epistêmico (BACCEGA, 1998; HENRY, 1992). O uso da linguagem pelo sujeito do conhecimento se materializa na manipulação e construção de conceitos. Assim, a forma linguística empregada para a manifestação de um determinado conceito determina, em larga medida, o impacto que ele terá em seu contex to de uso.

A reprodução de um conceito pode caracterizar um indivíduo cognitivo ${ }^{13}$, mas não um sujeito epistêmico ${ }^{14}$. Para o sujeito epistêmico, a produção intelecto-cognitiva dependerá de uma linguagem, pois, a episteme é um fenômeno diretamente relacionado ao logos, ou seja, ao discurso, à linguagem que se fala sobre algo, sobre o conhecimento. Não se pretende tratar o sujeito epistêmico como "sujeito da ciência" apenas (DOR, 1989, p.128 ${ }^{15}$ apud FURLANETTO, 2003, p.100), mas concorda-se com Furlanetto (2003, p.101) que afirma que a posição ocupada pelo sujeito epistêmico é aquela “[...] de onde se pode produzir conhecimento".

Indo um pouco além, considera-se que esse sujeito epistêmico é um sujeito fundamentalmente calcado no universo do discurso e da comunicação. Baseando-se em Wittgenstein ${ }^{16}$, Novellino (1998, p.142) afirma que "A linguagem existe apenas como comunicação e enquanto transmitida, e são as condições desta comunicação e transmissão e suas implicações que devem ser esclarecidas". O mesmo pode ser verificado no fluxo informacional quando são rompidas as "regras pragmáticas" que estabelecem a interação comunicativa entre pares. Assim, de acordo com González de

\footnotetext{
${ }^{13}$ Chama-se de indivíduo cognitivo aquele que pensa, mas se expressa na linguagem pela verbalização de enunciados desarticulados, sem sentido. Por outro lado, a relação entre linguagem e pensamento é um "[...] trabalho que visa significar, que produz sentido, produz linguagem, enfim.” (TÁLAMO, 2004, p.4).

${ }^{14}$ A referência ao sujeito epistêmico demarca nossa abordagem no ambiente da linguagem enquanto acontecimento do conhecimento. O termo sujeito epistêmico pode ser encontrado na literatura de diversas áreas, porém, com o princípio básico do sujeito cognitivo ou do sujeito que conhece. Aqui, o termo foi retirado do campo semiótico-cognitivo e linguístico-pragmático (GONZÁLEZ DE GÓMEZ, 1982, p.28; MORENO, 2005, p.18).

${ }^{15}$ DOR, Joël. Introdução à leitura de Lacan - O inconsciente estruturado como linguagem. Porto Alegre: Artes Médicas, 1989.

${ }^{16}$ WITTGENSTEIN, L. Investigações filosóficas. São Paulo: Abril, 1984.
} 
Gómez (1990, p.120), "Se não existe nenhuma expectativa sobre a aceitação recíproca dessas regras, não existirá comunicação, não existirá ‘fluxo’ de informação”. Um sujeito cognitivo que conhece precisa dominar as regras de uso de sua linguagem para a construção e a comunicação de seu discurso e, principalmente, em um processo dialético, ser compreendido e compreender no outro (no universo do Outrem estão, segundo Deleuze e Guattari (2004), o "eu” e o outro). Dessa maneira, "Las reglas organizan la experiencia práctico-discursiva, generando regularidades que se constituyen sobre el contrato local de los participantes de una relación intersubjetiva mediada por la lenguaje" (GONZÁLEZ DE GÓMEZ, 1996, p.48).

Os conceitos manifestam esse universo de produção de conhecimento, ganhando potência no uso da linguagem ${ }^{17}$. Além de serem expressos pela linguagem, também dependem de uma estrutura, composta por enunciados relevantes, que os "fixem" em um determinado contexto linguístico.

Os enunciados relevantes e a "fixação" de conceitos costumam remeter diretamente ao ambiente científico. Este é um aspecto significativo, pois, muitos teóricos das ciências atribuem importância fundamental ao uso da linguagem pela comunidade científica. Nessas discussões, tanto nos estudos teóricos quanto filosóficos da ciência, as questões não remetem à história e aos métodos de produção do conhecimento de uma ciência específica, mas à forma como é usada a linguagem para formular e transmitir tal conhecimento. Um ponto, então, pode ser levantado: continuase a analisar o conhecimento em Ciência da Informação por meio da epistemologia clássica ou opta-se por uma análise que recorre às suas variantes mais dinâmicas e sistêmicas como as poli-epistemologias ${ }^{18}$ ?

Quando se refere às variantes dinâmicas e sistêmicas no estudo do conhecimento e

\footnotetext{
${ }^{17}$ Refere-se ao uso da linguagem pelo sujeito epistêmico para a manifestação de conceitos. A "potência" da linguagem é infinita, mas, segundo Deleuze (2007, p.31), a potência do sujeito que usa a linguagem é limitada. O sujeito a que se refere é um ser humano, por isso há uma situação limite em sua linguagem. Mesmo sem ter um enfoque específico sobre a semiótica, não se quer confundir o que está sendo chamado de sujeito epistêmico com o Interpretante de Peirce que, segundo Eco (1984, p.33), “[...] não é o interprete, não é o ser humano que recebe o signo." O interpretante de Peirce, continua Eco, "[...] "é um signo que substitui outro signo', ou seja, em nossos termos 'é uma expressão que substitui outra expressão'." No campo da semiótica é esta seqüência de signos ou expressões que pode levar a um "processo de semiose ilimitada" (LARA, 1999, p.92) ou a uma "cadeia infinita de associações entre signos" (TÁLAMO, 2004, p.8). Para uma discussão mais aprofundada sobre signo e semiose documentária, ver Lara (1999, p.60-107; 2006).

18 Sobre questões poli-epistemológicas no campo da Ciência da Informação, ver González de Gómez (2000).
} 
usa-se o conceito de poli-epistemologias, se está diante de uma perspectiva pragmática ${ }^{19}$ do conhecimento e da informação. Não se discutirá em detalhes o pragmatismo na Ciência da Informação, mas é importante tê-lo como pano de fundo para delimitar alguns argumentos do âmbito da epistemologia da linguagem. É importante caracterizálo em dois momentos: o primeiro, segundo Pinto (1999, p.84), é aquele em que o pragmatismo surge, na primeira metade do século $\mathrm{XX}$, “[...] da aplicação do modelo biológico darwiniano ao conhecimento", tendo como resultado a "[...] constatação de que o conhecimento é constituído por meio do processo pelo qual os seres humanos se adaptam ao meio ambiente". Isso implica romper com a idéia de contemplação "desinteressada" da filosofia tradicional e estabelecer o princípio pragmático do conhecimento como “[...] instrumento para a ação, obtido por meio da participação interessada". (PINTO, 1999, p.84). O segundo momento, ainda de acordo com o autor, ocorre na segunda metade do século XX, “[...] quando o pragmatismo recebeu novo alento (em uma perspectiva lingüística), com os trabalhos de Wittgenstein, Quine e Sellars [...]" (PINTO, 1999, p.86). Neste segundo momento, de acordo com Pinto, é que se apresenta a pergunta fundamental do pragmatismo wittgensteiniano, ou seja, a pergunta sobre o uso das palavras.

No campo de estudos sobre a informação, González de Gómez (1996, p.45) afirma que a pragmática poderia dar elementos para “[...] superar los limites, simplificaciones y exclusiones de las Teorías Sintática y Semántica de la Información”. Assim, na visão da autora, a pragmática permitiu que a informação fosse analisada em seu ambiente de linguagem e comunicação, em que seu significado tomará a forma que os falantes de uma determinada língua, com suas regras de uso, definirem no momento em que estão se comunicando. Com base em Frohmann ${ }^{20}$, González de Gómez (1996) afirma que a relação semântica entre conceitos dependerá dos contextos prático-

\footnotetext{
${ }^{19} \mathrm{O}$ conceito de pragmática pode ser confundido com a idéia de prática. Um sujeito pragmático ou pragmatista é um sujeito prático, que não usa teoria, que só se vale da prática. É nesse sentido, por exemplo, que Dahlberg (1991) tece sua crítica à falta de fundamentação teórica da Classificação Decimal de Dewey. Para Dahlberg (1991, p.103) Dewey foi um pragmatista que julgava que qualquer tratamento teórico ao seu sistema era desnecessário. Não é este o sentido que se adota para o termo. Fala-se de pragmática enquanto uso da linguagem, sem colocar em questão e, muito menos, em oposição a teoria e a prática. Limita-se a identificar a pragmática no campo da linguagem, especificamente, na linha de uso de palavras e conceitos na experiência comunicativa e discursiva das coletividades, pois, se acredita que é dessa maneira que a pragmática, por meio da filosofia pragmática da linguagem, é tema de análise da epistemologia e organização do conhecimento na Ciência da Informação.

${ }^{20}$ FROHMANN, Bernard. An investigation of the semantic bases of some theoretical principles of classification proposed by Austin and the CRG. Cataloging and classification quarterly, v.4, n.1, p.1127, 1983.
} 
discursivos nos quais ocorre a comunicação. Para esta última, "Lo que junta, agrega y separa conceptos, textos, saberes, son las prácticas compartidas por subjetos sociales localizados en el tiempo y en el espacio.” (GONZÁLEZ DE GÓMEZ, 1996, p.47).

Tais características não apenas definem, grosso modo, os princípios básicos de uma pragmática semântica, linguística e filosófica, mas, também colocam os campos de estudos sobre a informação, especialmente, o da Organização e representação da informação e do conhecimento, no âmbito da epistemologia da linguagem.

\subsection{Conceitos e domínios do saber}

Numa discussão sobre as diferenças e as complementaridades entre as ciências da natureza e as ciências do homem, Granger (1994, p.85) levanta a questão sobre a legitimidade de se atribuir o nome de ciência aos saberes advindos dos fatos humanos. Para ele, as principais dificuldades no paralelo entre as ciências formais (física e matemática, por exemplo) e as ciências humanas estão na “[...] natureza dos fenômenos de comportamento humano, que carregam uma carga de significações que se opõem à sua transformação simples em objetos, ou seja, em esquemas abstratos lógica e matematicamente manipuláveis". A idéia de redução dos fatos humanos a objetos manipuláveis é difícil por conta de sua complexidade e imprevisibilidade. Dessa forma, afirma Granger (1994, p.86), a redução dos fenômenos ou fatos sociais e humanos a esquemas abstratos deve ser substituída pela sua representação em "sistemas de conceitos".

Na discussão do problema, Granger (1994) cita Freud, Piaget, Durkheim, Saussure, Jakobson, entre outros. Reproduzimos abaixo três citações analisadas por Granger.

Freud: 'O resultado mais importante a que chegamos num tal prosseguimento conseqüente da análise é o seguinte: seja qual for o sintoma de que partimos, sempre, infalivelmente, chegamos à área da experiência sexual' (Sobre a etiologia da histeria, 1896, Oeuvres complètes, III, p.157).

Durkheim: 'Assim, se as crises industriais ou financeiras aumentam os suicídios, não é porque empobreçam, já que as crises de propriedade têm o mesmo resultado; é porque são crises, ou seja, perturbações da ordem coletiva' ( $O$ suicídio, 1897).

Saussure: 'A língua é um sistema cujas partes podem e devem, todas, ser consideradas em sua solidariedade sincrônica' (Cours de linguistique générale, 1916, p.127). (GRANGER, 1994, p.87-88).

Na análise, Granger (1994, p.88) constata que "[...] parte desses enunciados utiliza conceitos aparentemente tomados à experiência ordinária, sem grande elaboração 
específica, ao contrário do caso das ciências da natureza e das matemáticas”. Será visto mais sistematicamente, em capítulo posterior, como Granger estabelece distinções entre diversos tipos de conceitos, em especial os filosóficos e científicos; por outro lado, é necessário destacar que o autor não desqualifica as disciplinas que atuam no cotidiano humano; ao contrário, identifica as limitações produzidas dentro de cadeias complexas de significações e juízos de valor típicos dos fatos e dos fenômenos humanos e sociais. Dessa maneira, a inserção de objetos de estudos em sistemas conceituais é necessária para a representação de fatos da realidade direta ou indiretamente relacionados à condição e sociedade humanas. Sobre a pergunta se "Devemos traçar fronteiras às ciências?", Granger (1994, p.113. Grifos do autor) é enfático e diz “não”, pois,

[...] nenhuma razão derivada da natureza da ciência obriga a se delimitar seu campo de investigação. No entanto, nem toda espécie de fenômeno lhe é igualmente acessível. O obstáculo único, mas radical, me parece ser a realidade individual dos acontecimentos e dos seres. O conhecimento científico exerce-se plenamente quando pode neutralizar essa individuação, sem alterar gravemente seu objeto, como acontece em geral nas ciências da natureza. No caso dos fatos humanos, ela se empenha por envolver cada vez mais estreitamente o individual em redes de conceitos, sem esperar um dia poder atingi-lo. Este é o único sentido de uma limitação.

Mas parece que, em alguns momentos, as ciências, ou melhor, os cientistas, debatem as fronteiras entre as disciplinas, em especial, sobre seus conceitos. Pode-se dizer que, desde que Snow (1995), no final da década de 1960, caracterizou o universo dos cientistas e o universo dos literatos ou intelectuais como As duas culturas, muitos debates foram realizados sobre a originalidade e a apropriação de conceitos. Snow (1995, p.26) dizia à época que “[...] os humanistas não conhecem conceitos básicos da ciência e os cientistas não tomam conhecimento das dimensões psicológicas, sociais e éticas dos problemas científicos". A discussão desse tema, no entanto, só seria retomada com força no final da década de 1990, quando foi promovido um evento específico, conhecido como "guerras da ciência" (science wars) (SANTOS, 2004, p.19). Sokal e Bricmont (2001) questionavam as apropriações que pensadores como Jacques Lacan, Julia Kristeva, Luce Irigaray, Bruno Latour, Jean Baudrillard, Gilles Deleuze e Félix Guattari, Paul Feyerabend, Thomas Kuhn, Jean-François Lyotard e Paul Virilio fizeram de conceitos e terminologias, notadamente, da física e da matemática.

A discussão sobre as fronteiras entre as ciências e as "fronteiras conceituais" é certamente complexa. O que pode ser retido dessa discussão é que os domínios de pertinência dos conceitos devem ser definidos dentro de fronteiras, não significando, 
porém, que os campos do saber não se relacionam. Ao contrário, os diálogos são importantes para a fertilização dos campos científicos.

As obras de Santos (2005; 2004), Um discurso sobre as ciências e Conhecimento prudente para uma vida decente: 'um discurso sobre as ciências' revisitado, deixam claro que as ciências podem romper suas fronteiras, sendo, na realidade, uma necessidade a relação e a inter-relação entre os saberes. Sem limites rígidos, os conceitos podem "migrar" de uma disciplina para outra. É possível pensar que o efeito migratório seja parte constitutiva da inter ou transdisciplinaridade.

A migração conceitual, entendida como o uso de conceitos de um domínio por outro, foi sintetizada por Edgar Morin:

Os conceitos viajam e é melhor que viajem sabendo que viajam. É melhor que não viajem clandestinamente. É bom também que eles viajem sem serem percebidos pelos aduaneiros! De fato, a circulação clandestina dos conceitos ao menos permitiu às disciplinas respirar, se desobstruir. A ciência estaria totalmente atravancada se os conceitos não migrassem clandestinamente. Mendelbrot dizia que as grandes descobertas são frutos de erros na transferência dos conceitos de um campo a outro, realizadas, acrescentava ele, pelo pesquisador de talento (MORIN, 2005, p.117).

Da forma como foi exposta por Morin, a migração conceitual pode ser sujeita a críticas. Mas, parece ser um equívoco definir os conceitos, mesmo os conceitos científicos, como unívocos, determinados e fixos em domínios isolados. Primeiro, como afirma Fourez (1995, p.129), existem saltos interpretativos de paradigma para paradigma quando se procuram relações entre seus conceitos; além disso, "Os cientistas imaginam por vezes possuir conceitos precisos e univocamente determinados; estes não teriam significação se não fossem traduzíveis na experiência mais flexível do cotidiano." e isso implica um vínculo entre a “[...] linguagem do cotidiano e os conceitos científicos." (FOUREZ, 1995, p.131-135).

Na Ciência da Informação é corrente a discussão sobre a consolidação do campo disciplinar. Nessas discussões, evidencia-se um aspecto importante: a dificuldade de fundamentar seu campo teórico em um sistema conceitual próprio.

Porém, a consolidação de um sistema de conceitos encontra sua maior dificuldade no próprio conceito "Ciência da Informação". Geralmente, a tentativa de conceitua-lo reaviva, inevitavelmente, as teorias sobre a própria concepção de ciência e de 
informação ${ }^{21}$.

Como exemplo de estudo dessa natureza, pode ser citada a pesquisa terminológica de Smit, Tálamo e Kobashi ${ }^{22}$ (2004) na qual foram analisadas as noções específicas, semi-elaboradas, tomadas de empréstimo, da experiência empírica comum e da terminologia de área da Ciência da Informação. Para as autoras a Ciência da Informação é uma ciência formada (ou em formação) em bases interdisciplinares que toma quadros nocionais de "[...] empréstimo de disciplinas tais como a Lógica, a Administração, a Lingüística, a Teoria Geral dos Sistemas, a Psicologia, as Ciências da Computação, etc.”, o que revelaria uma “[...] inconsistência teórica, associando à área uma abordagem a-histórica" (SMIT; TÁLAMO; KOBASHI, 2004, p.1). A Ciência da Informação se constituiria a partir de conceitos de outras áreas, dependendo das necessidades do objeto investigado, caracterizando-se por um "vazio" conceitual, preenchido "circunstancialmente". Esse fenômeno é atribuído pelas autoras à ausência de um “corpo conceitual” consolidado.

Se não existe um corpo conceitual próprio da Ciência da Informação, a busca de soluções para os problemas da área é deslocada para outras disciplinas, levando à importação de conceitos, nem sempre apropriados. Usa-se "apropriados" no duplo sentido do termo, ou seja, nem sempre a Ciência da Informação se apropria de conceitos de outras áreas e lhes dá um sentido próprio, como nem sempre a apropriação é adequada.

O deslocamento conceitual desordenado e a falta de critérios na apropriação de conceitos desencadeiam uma seqüência de imprecisões terminológicas e, por extensão, o "retardamento teórico" da área (SMIT; TÁLAMO; KOBASHI, 2004, p.3).

As autoras também identificam a dificuldade de se eliminar a ambigüidade da linguagem das Ciências Humanas e Sociais, pois,

Não se pode delas eliminar a contingência, o processo histórico e a realidade social; de modo geral a possibilidade de diversas interpretações, são em sua maioria baseadas num recurso à experiência. Neste contexto, próprio da controvérsia, a condição fundamental da lógica - a univocidade entre o

\footnotetext{
${ }^{21}$ Existe uma série de livros, artigos, teses e outros trabalhos acadêmicos que se debruçaram sobre o conceito de Ciência da Informação e suas mais variadas perspectivas, especialmente, tratando do conceito ciência e informação separadamente para depois reuni-los. Como exemplos estão: os livros de Robredo (2003) e Le Coadic (2004), sobre Ciência da Informação; o verbete de Wilden (2000), sobre informação; e o artigo de Capurro e Hjorland (2007), também sobre o conceito de informação.

${ }^{22} \mathrm{Em}$ artigo anterior (KOBASHI; SMIT; TÁLAMO, 2001), as autoras já haviam levantado as hipóteses que agora aprofundam com uma pesquisa terminológica.
} 
termo e o conceito - não pode ser obtida. (SMIT; TÁLAMO; KOBASHI, 2004, p.5).

Porém, como também já alertou Galvão (1998, p.51), o ecletismo conceitual da área não pode ser um obstáculo (nem uma justificativa) para que uma linguagem especializada, própria da área, seja construída e consolidada. Nas palavras de Smit, Tálamo e Kobashi:

A autonomização da linguagem de especialidade, afastando-a da linguagem natural, constitui um pressuposto para a constituição de qualquer campo científico e, portanto, igualmente, para a constituição da Ciência da Informação. Dito ainda em outros termos, nenhum campo científico se impõe no ambiente da pesquisa acadêmica se não dispuser de uma linguagem própria, ou seja, de uma linguagem especializada. E, para cumprir a função de uma linguagem especializada, esta pressupõe, por sua vez, que os termos da mesma remetam a conceitos específicos, distintivos. (SMIT; TÁLAMO; KOBASHI, 2004, p.6).

Para Galvão (1998), formular conceitos é o caminho para romper "epistemologicamente" com o senso comum e aproximar-se da ciência. Da mesma forma, segundo Tálamo (2004, p.10), “[...] a ausência de uma estrutura conceitual não permite ir além do senso comum, ou seja, aceita-se o que existe tal como existe, ou ainda, aceita-se o que existe tal como enunciado pelo emissor".

Quais poderiam ser as respostas para a pergunta: a Ciência da Informação tem um domínio científico estabelecido? Se a resposta contemplar a premissa de que domínios científicos têm por base um corpo conceitual estabelecido, conclui-se com Smit, Tálamo e Kobashi (2004) que a Ciência da Informação não tem esse domínio estabelecido. Se não há um corpo conceitual estabelecido, isto é, um domínio científico, como é possível falar de conhecimento científico da área? Ora, na ausência desses elementos, não parece ser possível falar de epistemologia e de paradigmas. As abordagens epistemológicas na área seriam melhor caracterizadas como abordagens hermenêuticas, pois, temos conjuntos de textos e não, necessariamente, de conceitos. Fundamentos, revoluções e rupturas epistemológicas, assim como paradigmas, são temas que só podem ser tratados em áreas com uma trajetória histórico-conceitual em torno de objetos, teorias e metodologias definidas e próprias. Como demonstraram Smit, Tálamo e Kobashi (2004, p.6-7), o histórico que começa com a Biblioteconomia, passa pela Documentação e chega à Ciência da Informação configura-se apenas como uma "[...] evolução no tempo, com o respectivo deslocamento de ênfase (do acervo para o acesso) [...]". O histórico do conhecimento científico da área é composto por ênfases em procedimentos e não em corpos de conceitos, teorias e metodologias. Não por acaso, quando se remete aos 
estudos epistemológicos da área, eles aparecem caracterizados e fundamentados nas mais diversas disciplinas (na realidade fala-se mais dos conceitos dessas disciplinas do que propriamente da Ciência da Informação), numa tentativa de analisar vazios conceituais preenchidos circunstancialmente.

Em meados do século passado, Shera (1957), com base em Whitehead ${ }^{23}$, afirmava que não existem certezas na ciência, que elas são um "engodo", uma "ilusão", e que qualquer tratamento "[...] das doutrinas científicas é controlado pelos conceitos metafísicos da época em que foram produzidos. Qualquer conceito ou entidade é uma modificação de seu ambiente e não pode ser reproduzida fora dele" (SHERA, 1957, p.2). Por isso, pode-se entender que, quando um conceito de uma área é "apropriado" por outra, ele deve passar por um processo de re-significação. As migrações conceituais, o romper as fronteiras, a formação de um núcleo teórico e conceitual, seja qual for a nova situação de um conceito, devem ser plenas. Não há limites para os significados dos conceitos, nem para suas expressões, mas isso não significa que eles devam ser tomados de empréstimo ou criados sem de rigor.

A permanência de um conceito ao longo da história ocorre, justamente, por meio daquilo que mais se teme, ou seja, a não-resistência a reformulações e, até mesmo, por meio de apropriações por outros campos do conhecimento, que acabam revitalizando um conceito já quase extinto em sua área de origem. Se analisarmos a história dos próprios conceitos da Ciência da Informação (RABELLO, 2008; KOSELLECK, 1992) veremos uma trajetória de reformulações e apropriações que, em diversas situações e momentos, mudaram sua ordem e conteúdo. Mas, nem sempre, como afirma Koyré (1991, p.16), as cronologias espirituais e astronômicas coincidem, cabendo considerar a datação do "tempo histórico", na perspectiva de Koselleck (2006, p.13), como um pressuposto e não uma determinação. Vickery (1980, p.187) afirma, também, logo no início de seu histórico das classificações da ciência, que a história não é linear e nem unificada, ela é "mais ou menos" unificada e definitivamente não-linear.

É evidente que a diversidade conceitual é importante, como afirma Fujita (2008), referindo-se à constituição científica da Organização e Representação do Conhecimento (ORC). Outras perspectivas também podem ser citadas, como a que fornece o exemplo ideal da ultrapassagem (ou não) dos limites de um conceito: a metáfora.

\footnotetext{
${ }^{23}$ WHITEHEAD, Alfred North. Adventures of ideas. New York: Macmillan, 1933. p.196-7.
} 
Já se teve a oportunidade de dizer que as metáforas mitológicas deram lugar aos conceitos, mas suas fibras, seus traços, não se perderam totalmente. Em certo sentido, os grandes ensinamentos da humanidade foram transmitidos e mantidos por meio de grandes metáforas que sedimentaram conceitos tornando-os, paradoxalmente, enigmáticos. Por vezes, ainda, a forma mais acurada de um espírito racional (no sentido do uso extremo da razão como a forma lógica de enunciar verdades) foi relacionada ao fato de que a produção de enunciados claros e objetivos só poderia exprimir verdades. A síntese da razão extrema vem acompanhada de um esforço ainda maior de interpretação. Wittgenstein ${ }^{24}$ e Nietzsche são exemplos desses esforços e, deste último, empresta-se a definição de verdade: “[...] as verdades são ilusões, das quais se esqueceu que o são, metáforas que se tornaram gastas e sem força sensível, moedas que perderam sua efígie e agora só entram em consideração como metal, não mais como moedas" (NIETZSCHE, 1987, p.34, v.1).

Partindo desses dois pensadores, em suas diferentes fases, pode-se pensar que usar a razão para construir conceitos (como os de ética, moral e verdade) é, justamente, criar (com) metáforas. Assim, dando seqüência ao raciocínio até aqui desenvolvido, portanto, ainda no âmbito da discussão dos limites dos conceitos, são abordadas, a seguir, as relações entre razão e metáfora.

\subsection{Razão e metáfora na ordem dos conceitos}

O que é a verdade portanto? Um batalhão móvel de metáforas, metonímias, antropomorfismos, enfim, uma soma de relações humanas, que foram enfatizadas poética e retoricamente, transpostas, enfeitadas, e que, após longo uso, parecem a um povo sólidas, canônicas e obrigatórias: as verdades são ilusões, das quais se esqueceu que o são, metáforas que se tornaram gastas $e$ sem força sensivel, moedas que perderam sua efígie e agora só entram em consideração como metal, não mais como moedas. (NIETZSCHE, 1987, p.34, v.1).

Já foi dito que os conceitos se locomovem, viajam de um canto a outro sem

\footnotetext{
${ }^{24}$ Wittgenstein, como muitos filósofos, faz uso freqüente de metáforas, como a dos próprios jogos de linguagem, as semelhanças de família e o indizível. Alguns trechos famosos do Tratactus são bons exemplos: "A linguagem é um traje que disfarça o pensamento" (WITTGENSTEIN, 2001, p.165, §4.002); "Os limites da minha linguagem significam os limites de meu mundo" (WITTGENSTEIN, 2001, p.245, §5.6); "Sobre aquilo de que não se pode falar, deve-se calar." (WITTGENSTEIN, 2001, p.281, §7). No caso das Investigações (WITTGENSTEIN, 2005), Geertz (2006, p.111) se refere a ela como uma "[...] coleção de jogos conceituais e metáforas inesperadas [...]”. Evidentemente, outros autores poderão discordar sobre a existência de metáforas em Wittgenstein ou em Nietzsche, argumentando que ambos fazem uso de efeitos de linguagem, mas não de metáforas.
} 
limites e fronteiras rígidos. Nesse percurso, eles são re-significados. A linguagem usada por uma razão inquieta e inconformada com métodos e normas pré-definidos conduz a uma potência criadora de conceitos que estão à margem do formalmente conhecido e reconhecido. O conceito de verdade em Nietzsche, com o qual se abriu o presente tópico, é um exemplo de como a linguagem pode ser usada para construir conceitos que rompem fronteiras, ou seja, rompem os limites da própria história para fazerem parte de uma nova história. Quando Nietzsche (1987, p.34, v.1) diz que a verdade é "um batalhão móvel de metáforas [...]", que as verdades são "ilusões", parece estar se referindo a algo distante da realidade, mas, ao mesmo tempo, tão próximo das experiências da vida que se acaba por acreditar que as verdades são metáforas e ilusões.

Outro exemplo é o conceito de "informação" de Wilden (2000) em seu verbete sobre informação, na Enciclopédia Einaudi:

A informação apresenta-se-nos em estruturas, formas, modelos, figuras e configurações; em idéias, ideais e ídolos; em índices, imagens e ícones; no comércio e na mercadoria; em continuidade e descontinuidade; em sinais, signos, significantes e símbolos; em gestos, posições e conteúdos; em frequências, entonações, ritmos e inflexões; em presenças e ausências; em palavras, em acções e em silêncios; em visões e em silogismos. É a organização da própria variedade. (WILDEN, 2000, p.11).

A exemplo do conceito de verdade, o conceito de informação de Wilden comporta um forte apelo metafórico, mas nem por isso deixa de ser um conceito, sendo possível dizer que a informação pode apresentar-se como uma "ausência", uma "presença" ou em "silêncios", assim como é possível dizer que a verdade é uma moeda gasta e a realidade um mar turbulento.

Na comunicação do dia-a-dia, os discursos são entendidos porque fazem parte de paradigmas $^{25}$ apreendidos no uso da linguagem. Muitos paradigmas usados no cotidiano são construídos como metáforas que ajudam a entender melhor a realidade. Um sujeito pode ter uma linguagem constituída de poucos elementos, porém, a combinação dos elementos dessa linguagem e os "[...] níveis do discurso disponíveis nos sistemas linguísticos são potencialmente infinitos" (WILDEN, 2000, p.46). O que é interessante é que o sujeito do discurso ou da linguagem sabe que a mesma linguagem que ele usa e que lhe dá "infinitas" possibilidades combinatórias também é usada por outros na mesma perspectiva, ou seja, o sujeito sabe que ele tem chance de manter comunicação

\footnotetext{
${ }^{25}$ Com base na terminologia de Jakobson, Wilden (2000, p.46) diz que dentro da estrutura de eixos paradigmático e sintagmático, o eixo paradigmático corresponde "[...] estreitamente ao que é usualmente chamado metáfora $[\ldots .]$.
} 
regular com outro se compartilharem os mesmos paradigmas (por exemplo, de que a informação apresenta-se em "silêncios" e "ausências" ou que a verdade é uma "ilusão", uma "metáfora").

Tais paradigmas seriam formas de complemento sobre o conceito de verdade ou de informação, por exemplo. Porém, de acordo com Ricoeur ${ }^{26}$ (2000), conceitos não são o mesmo que metáforas ${ }^{27}$, em sentido literal, mas as abstrações metafóricas são complementos das abstrações conceituais. A abstração metafórica

[...] não consiste em esquecer, ignorar ou eliminar os atributos secundários, mas é uma regra para completar a estrutura e para diferenciá-la (assim, no conceito de metal está contida a representação de diversas cores possíveis). (RICOEUR, 2000, p.165).

Para Pinker (2008, p.317) as metáforas "vivas" nunca poderiam ser aprendidas ou usadas pelo raciocínio se não "[...] fossem construídas a partir de conceitos mais abstratos que captassem as semelhanças e diferenças entre o símbolo e o que está sendo simbolizado". O autor vê nas metáforas a "chave" que explica a relação entre pensamento e língua. Em sentido metafórico, a metáfora, segundo Pinker (2008, p.317), proporciona meios para “[...] palpar o impalpável” e que talvez o "[...] maior prazer que a língua permita seja o ato de nos render às metáforas de um autor habilidoso e assim morar na consciência de outra pessoa".

Os conceitos, caracterizados na Organização do Conhecimento como unidades de pensamento ou conhecimento para serem operacionalizados, devem ser biunívocos, comportando a relação de um significante para um significado. (TÁLAMO, 1987; CINTRA et al, 2002, p.69). Dificilmente, portanto, os conceitos poderiam comportar ordens metafóricas, polissêmicas e ambíguas.

A linguagem natural caracteriza-se pelas inúmeras possibilidades de significados que podem ser emprestados a uma palavra ou termo. Segundo Cintra et al (2002, p.68), a linguagem natural é um “[...] espaço para o exercício da liberdade”, é dinâmica e plurissignificativa, ao passo que as linguagens construídas devem significar de "maneira

\footnotetext{
${ }^{26}$ Baseando-se em Michel Le Guern e Hedwig Konrad, Ricoeur (2000) analisa os fundamentos lógicolingüísticos da denominação metafórica. Reproduzimos abaixo as referências das obras dos autores da mesma forma que Ricoeur (2000, p.163. Notas):

Michel Le Guern, Sémantique de a métaphore et de la métonymie, Paris, Larousse, 1973, p.121.

Hedwig Konrad, Étude sobre la métaphore, Paris, Lavergne, 1939; Paris, Vrin, 1959.

${ }^{27}$ Os conceitos são classificados em estruturas por meio de traços e atributos gerais, são subordinados e coordenados sistematicamente, dessa forma, "[...] o conceito é precisamente o símbolo desta ordem fundamental, isto é, do sistema de relações que liga entre si os elementos de um objeto particular." (RICOEUR, 2000, p.165).
} 
precisa", impondo "[...] significados fixos, de maneira coercitiva". Ao contrário da linguagem natural, as linguagens documentárias procuram evitar que vários significados sejam atribuídos a uma forma significante; da mesma forma, diferentes significantes não são empregados para um mesmo significado, sem que haja registro sobre a operação de controle da significação (CINTRA et al, 2002, p.67).

A figura abaixo esclarece a idéia de um significante para um significado nas linguagens construídas e um significante para vários significados na linguagem natural.

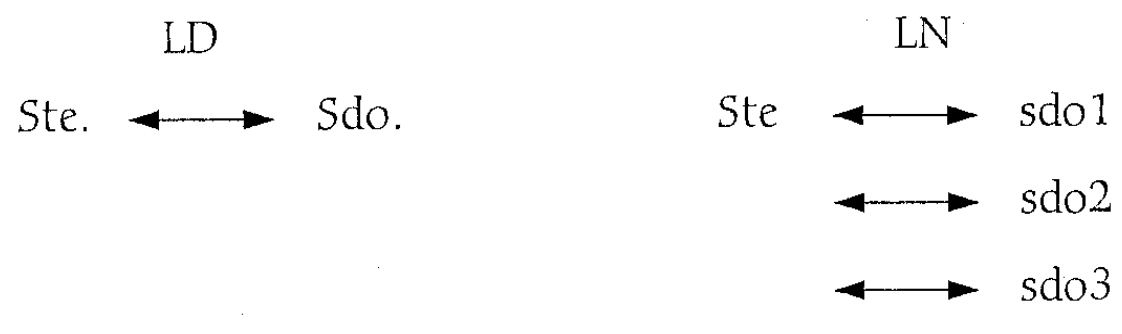

(Fonte: CINTRA et al, 2002, p.69)

As linguagens documentárias têm função "informativa" e não de criação. As linguagens documentárias “[...] compreendem unidades capazes de representar informação. Não é suficiente que tais unidades signifiquem. É necessário que elas signifiquem de maneira determinada" (CINTRA et al, 2002, p.69). Assim, a metáfora é, via de regra, um elemento descartado na operacionalização de conceitos. Os aspectos semânticos podem ser levados em consideração na dinâmica dos conceitos (como procurou-se demonstrar por aquilo que se denominou anteriormente de "migração" e "fronteiras" conceituais) por meio de seus traços característicos e usos em contextos definidos, mas conceitos metafóricos não permitem ligar um significante a um único significado. Não seria possível, por exemplo, estabelecer uma ordem relacional para os conceitos "verdade" e "informação" conforme foram definidos acima. Suas definições impossibilitam qualquer tipo de identificação em algum domínio, pois, carecem de conteúdo objetivo e especializado. Isso não as tornam vazias de significados, ao contrário, elas possuem tantos significados possíveis que a simples tarefa de classificálas torna-se um exercício extremamente complexo e quase sempre infrutífero devido à amplitude de aplicação permitida.

Lembrando a idéia de paradigma da linguagem, é possível introduzir o argumento de que o conceito não precisa, necessariamente, estar relacionado a objetos para ser considerado verdadeiro, ter credibilidade científica e/ou sobreviver ao longo do tempo. 
A representação conceitual é aqui entendida como distinta do ato de nomear algo. Quando se atribui um nome a alguma coisa, essa coisa deixa de ser coisa-sem-nome para ser coisa-com-nome, mas isso não significa que ela represente por si só uma idéia ou um pensamento. Nomear algo não significa exatamente saber o que é esse $\operatorname{algo}{ }^{28}$; da mesma forma, pode-se conceituar algo e não encontrar um nome que o represente, ou seja, caracterizar um objeto não significa, necessariamente, nomeá-lo. Um objeto ou uma coisa pode existir a partir da descrição de suas características. Como diz Dahlberg (1978a, p.103), "Se o conceito ainda não tem nome é possível formulá-lo pela síntese das características descobertas". É evidente que quase tudo o que nos cerca possui um nome ou uma designação, porém uma coisa, um objeto ou um fato pode ser identificado a partir de suas características, sem que tenha uma etiqueta que o nomeie.

Usando o diálogo de Platão (1963), Crátilo, sobre a "justeza dos nomes", pode-se perguntar, por analogia, pela justeza dos conceitos $^{29}$. A elaboração de um enunciado conceitual traz características e elementos que nem sempre são imunes a interesses, ideologias ou "bairrismos". Isso, porém, não torna os conceitos nem mais, nem menos "justos", mas adequados.

Pensar em conceitos "adequados" e "justos" leva-nos, inicialmente, a discutir a formalização dos conceitos científicos e dos conceitos filosóficos e, num segundo momento, a perguntar pela possibilidade de uma identificação conceitual à margem da linguagem e, por extensão, do conhecimento chamado "autorizado" ou "universal".

Nessa perspectiva, afirma-se, inicialmente, que o conceito é elemento essencial da razão apta a produzir juízos e a formular questões e não apenas um elemento da razão que age por "estímulo-resposta", como observou Vuillemin $(1997)^{30}$. Ainda, segundo Costa (2008, p.14), “Uma das características da razão é a de poder exercer sua atividade por meio de conceitos até certo ponto vagos e inexatos, não exigindo precisão absoluta". Porém, é precisamente este aspecto que abre espaço para férteis discussões sobre até onde os conceitos representam realmente aquilo que se quer representar.

\footnotetext{
${ }^{28}$ No caso de um objeto, não é necessário, como diz Hegenberg (1974, p.67), ter sua definição exata e completa para conhecê-lo. O mesmo pode ser dito diante dos conceitos vagos da filosofia e do conceito de impreciso de Wittgenstein.

${ }^{29}$ Usa-se o diálogo de Platão apenas como analogia. Mas, não se pode deixar de destacar que Crátilo é uma obra clássica sobre os nomes. Outras obras que discutem o tema são: Campos (2004) e Brito (2003). Pinker (2008, p.320-367) também apresenta uma discussão interessante sobre "O que há num nome?".

${ }^{30}$ No verbete "Conceito" da enciclopédia Einaudi, Vuillemin (1997, p.77) distingue três tipos de conceitos: "[...] o conceito animal, que precede a linguagem, o conceito comum que caracteriza o homem e está ligado à linguagem ordinária e o conceito científico, cuja expressão requer uma linguagem técnica, matemática ou que faz uso da matemática."
} 
A idéia de metáfora como "redescrição" (RICOEUR, 2000) aponta saídas possíveis para a inexatidão conceitual e para os "limites da linguagem" (DIAS, 2000). No campo científico, o problema seria realizar "ajustes" para adequar os conceitos às mudanças epistemológicas e paradigmáticas e operacionalizá-los em contextos de organização e recuperação da informação.

A carga semântica de um conceito é de difícil determinação porque ocorre no sujeito e depende de suas experiências como indivíduo que pertence a uma determinada coletividade. Mesmo mapeando-se as regras e os jogos nos quais uma comunidade se baseia para fazer uso da linguagem, é difícil determinar até que ponto a autonomia do sujeito se sobrepõe às regras do grupo. É bom lembrar que todo sujeito pensante tem liberdade e autonomia para usar a sua razão, inclusive para criticar as regras coletivas.

Retornando a Costa (2008, p.14), pode-se dizer que a razão é responsável pela formulação de conceitos, constituindo categorias de maneira "objetiva”, "[...] ela é a faculdade de combinar conceitos, julgando e inferindo; sob este aspecto, sua função é tipicamente ativa". Costa indica, portanto, que os conceitos são constituídos em contextos racionais e têm função ativa, aspecto especialmente importante do ponto de vista das ações de informação.

\subsection{Ordem dos conceitos}

Lancaster (2004, p.21), referindo-se à classificação, observa que, em certos casos, as "[...] diferenças terminológicas são inexpressivas e só servem para confundir", deixando claro o desconforto com o uso contemporâneo de certos termos: "Minha maior queixa, porém, é o fato de o substantivo 'classification' haver sido praticamente substituído por (pasme-se!) 'taxonomy' (pasme-se duas vezes!), 'ontology' ou até (pasme-se três vezes!) 'taxonomized set of terms' [conjunto taxonomizado de termos]" (LANCASTER, 2004, p.xiii). Para Dodebei (2002), os termos linguagens documentárias e representação documentária têm sido empregados com o mesmo sentido. Segundo a autora, os dois conceitos são considerados como sinônimos pelo “[...] emprego indiscriminado da terminologia utilizada pelos campos teóricoconceituais da representação documentária [...]" que foram trazidos da Europa, com enfoque na analyse documentaire e dos modelos com enfoque na information indexing, que refletem o modelo americano (DODEBEI, 2002, p.39). 
$\mathrm{Na}$ Grécia antiga, com o nascimento da Filosofia, os questionamentos sobre as idéias e sobre o conhecimento ganharam importância, levando os pensadores a estabelecerem marcos fundamentais para pensar a organização das representações. Se as representações são feitas por meio de conceitos que são, por sua vez, espécies de "elos" com a realidade externa, é necessário categorizá-los e organizá-los para, dessa forma, também organizar a realidade. Apesar de Platão ter colocado em pauta algumas questões sobre a linguagem e a origem e a "justeza" dos nomes, foi Aristóteles que, por meio de suas "categorias" (ARISTÓTELES, 1995; PORFÍRIO, 2002), desenvolveu um quadro sistemático sobre o conhecimento, suas representações e a organização dos elementos do mundo.

Vickery (1980, p.236) para explicar o surgimento das categorias conceituais, afirma que

Todos os conceitos baseiam-se finalmente na percepção, mas a percepção não é uma maneira fixa e estática de adquirir conhecimento. É impregnada pela experiência passada, e como essa experiência se amplia e se aprofunda, então as categorias usadas para interpretá-la desenvolvem-se em número, complexidade e sutileza.

Além da questão da experiência do vivido, Vickery (1980) também lembra que o conhecimento e especialmente as categorias conceituais dependem de um processo ativo entre o "organismo" humano e seu ambiente, assim como de suas relações mentais e subjetivas.

Para Aristóteles, segundo Alvarenga (2001), a sabedoria depende da quantidade de conceitos que se possui e conhecer implica formar conceitos, aplicá-los à realidade e gerar conclusões sobre algo que não está presente. Para a autora,

Esta seria uma forma de se abordar a natureza física e abstrata, desvendandolhe os mistérios e enunciando verbalmente sobre cada faceta ou ângulo relacionado ao objeto observado, reconstruindo-se finalmente o objeto por meio da síntese de todas as facetas a ele relativas. (ALVARENGA, 2001, p.9).

Então, o homem, para formar conceitos e conhecer, classifica as coisas ao seu redor. Classificar é uma operação e/ou atividade natural e indispensável em nosso cotidiano. O "homem" sempre procura padrões, diz Shera (1957, p.3), ele não gosta do caos e encontra "[...] felicidade, conforto, segurança quando reconhece padrões familiares [...]" e todo padrão (ou classificação) é feito de conceitos.

Pombo (1998, p.19) afirma que nada “[...] nos parece mais 'natural', óbvio e indiscutível que as classificações dos entes, dos fatos e dos acontecimentos que 
constituem os quadros mentais em que estamos inseridos". Por outro lado, ao perguntar a alguém como ela "classifica" seu mundo, na maioria das vezes, não se obterá uma resposta e se isso ocorrer, a resposta não será satisfatória.

Dificilmente alguém dirá que classifica o mundo a partir de categorias de forma e conteúdo para que os conceitos sempre estejam bem organizados em sua mente, ajudando-o a fazer distinções, associações e, eventualmente, emitir conclusões próprias e até formular novos conceitos. As pessoas não precisam se preocupar com essas e com muitas outras explicações sobre coisas que fazem parte de suas vidas.

Pombo (1998, p.21) lembra que não é comum “[...] discutirmos as classificações a partir das quais o nosso próprio discurso se constrói” e que elas (as classificações), como parte essencial da constituição dos saberes, são códigos ordenadores institucionalizados, inseparáveis dos aspectos comuns e essenciais ao ser humano, como sua cultura, sua crença, sua política e seu conhecimento.

Nesse sentido, a autora propõe uma ordem de análise da classificação, começando por seus principais campos de atuação e/ou de orientação, passando pelo seu conceito, para chegar aos tipos de classificação. Considera como principais campos de orientação as ontologias (classificação dos seres), as gnosiologias (classificação das ciências), as classificações biblioteconômicas (classificação dos livros) e as informacionais (classificação da informação).

As classificações dos livros e das informações, chamadas de ciências da classificação $^{31}$, são consideradas um “[...] novo domínio científico que tem por tarefa o estudo de todos os possíveis sistemas de classificação". O objeto dessa nova ciência é o próprio conceito de classificação em "[...] sua idealidade e abstração máxima”. Com um objeto dessa natureza, o objetivo da ciência da classificação é estudar a constituição dos sistemas de classificação de maneira ampla, retomando os sistemas filosóficos (POMBO, 1998, p.21). É importante indicar que Pombo (1998, p.22) refere-se a cinco características gerais que poderiam compor o conceito de classificação. A primeira pressupõe um "mecanismo classificador" responsável pela operacionalização das ações necessárias à classificação; a segunda, define as "multiplicidades de fins" da classificação, que determinarão sua própria estrutura; a terceira característica comporta

\footnotetext{
${ }^{31}$ Pombo (1998, p.21) aborda separadamente os dois "níveis" anteriores, o ontológico (classificação dos seres) e o gnosiológico (classificação das ciências), mas reúne as classificações dos livros e as classificações das informações no que denomina "ciência da classificação".
} 
o "domínio da realidade" no qual a classificação será exercida; a construção de uma classificação sobre ou no contexto de "classificações precedentes" é a quarta característica; e, por fim, a quinta característica diz que toda classificação pressupõe uma "dupla operação" apresentada por um "produto externo da actividade classificadora". A autora dá continuidade à enumeração das características consideradas intrínsecas a todas as classificações reais e das ciências nomeando alguns pensadores clássicos e contemporâneos como Aristóteles, Bacon, Piaget, Ampère, Diderot e D'Alembert, Leibniz, Cícero, Peirce, Comte, Spencer, Wundt, Santo Agostinho, São Boaventura, Kedrov, Martianus Capella e Chambers, relacionando-os às características citadas acima. Por exemplo, no caso das classificações da ciência, sempre haverá um mecanismo classificador que

[...] melhor ou pior, executa as operações necessárias à classificação, tanto em termos da constituição de uma nomenclatura adequada aos diferentes arranjos disciplinares propostos (Ampère), como operando por obediência a exigências de proliferação (Bacon), de derivação (Leibniz), de linearidade (Comte), de regularidade e simetria (Ampère), de circularidade (Piaget), de hierarquia (St. Agostinho) ou mesmo de subordinação (S. Boaventura) [...]. (POMBO, 1998, p.23).

Pode-se notar que cada pensador da classificação (agente classificativo), inserido em determinado domínio classificatório ou domínio de realidade, procura desenvolver métodos ou mecanismos relacionados e/ou dependentes de sua própria especialidade que, por sua vez, influenciarão os tipos de classificação. Existem, segundo Perelman (1963 ${ }^{32}$ apud POMBO, 1998, p.24), dois tipos fundamentais de classificações: a) as dicotômicas, "baseadas na ausência ou presença de determinadas propriedades"; b) as "classificações baseadas numa propriedade qualificada como diferença específica". As classificações dicotômicas são logicamente mais satisfatórias devido ao rigor na divisão dos objetos que serão classificados. A Árvore de Porfírio é um exemplo de classificação hierárquica de gêneros e espécies baseada em dicotomias que vão do geral ao particular.

A classificação de Porfírio é, segundo Pombo, a primeira representação arborescente de classificação dicotômica, que teve grande influência em toda Idade Média.

No caso das classificações por diferenças específicas, baseadas na escolha de propriedades "incompatíveis", a autora diz que ela não é trivial em razão do número de

\footnotetext{
32 PERELMAN, C. (1963), "Réflexions Philosophiques sur la Classification", in Centre National de Recherche de Logique / Société Belge de Logique et Philosophie des Sciences (ed.), La Classification dans les Sciences, 231-236, Bruxelles: Éditions J. Duculot S.A. Gembloux.
} 
"propriedades que podem desempenhar a função de diferença específica", pois a escolha de uma ou outra propriedade possivelmente implicará diferentes classificações. Para Pombo (1998, p.26. grifo nosso) classificar é “[...] escolher uma entre outras classificações logicamente possíveis procurando encontrar, para a escolha feita, um conjunto de razões suficientes". A escolha de determinadas propriedades determinará como a realidade será estruturada e, conseqüentemente, será apresentada em distintas classificações. Mas, toda escolha pressupõe um ato arbitrário; além disso, as classificações preocupam-se com o "estabelecimento de classes" e fronteiras desconsiderando as imperceptíveis nuances que são responsáveis pela ligação dos seres no campo da história natural. Esta, segundo a autora, é a base da classificação proposta por Buffon no século XVIII. Ao contrário de Lineu, que tinha princípios fixistas e por isso via a natureza de maneira estática, Buffon partia de um continuismo natural que tinha no homem o princípio ordenador. De acordo com Pombo (1998, p.27)

[...] enquanto que Lineu, fundado nas suas convicções fixistas, procurava olhar, descrever, nomear as formas estáveis da natureza, identificar os caracteres essenciais dos seus géneros, espécies e classes, Buffon partia dos indivíduos, não ainda na sua organização interna, mas na sua fluida e luxuriante variedade de formas, na plasticidade dos seus comportamentos, na mobilidade da sua distribuição. É nesse sentido que para Buffon, a classificação 'mais natural' só pode ser aquela em que o homem ocupe o centro. O ponto de vista do homem é o único princípio a partir do qual a classificação se pode estabelecer.

As classificações naturalistas servirão como guias para as classificações das ciências desenvolvidas, a partir do século XIX, por Comte, Ampère e Peirce. As relações entre as classificações dos seres e as classificações dos saberes também são exemplificadas por Pombo, mas destacamos as classificações chamadas pragmáticas que encontram lugar "privilegiado" na classificação documental e biblioteconômica. Citando Bhattacharyya e Ranganthan, a autora esclarece a diferença fundamental entre a classificação documental e outros tipos de classificações:

[...] a diferença entre as classificações das ciências e as classificações documentais e biblioteconómicas reside justamente no carácter em geral meramente especulativo das primeiras em contraste com os intuitos funcionais imediatos das segundas. Enquanto que as primeiras são esquemas globais, sistemas teóricos que não descem a detalhes nem se enredam com minúcias de classificação de domínios restritos, as segundas são propostas minuciosamente elaboradas, em geral acompanhadas de um código em que cada classe é designada por um símbolo (veja-se o caso da classificação decimal de Melvil Dewey). (POMBO, 1998, p.30.)

Reconhecendo a importância da classificação de documentos, a autora cita vários avanços ocorridos nesse campo, quase todos atrelados aos avanços tecnológicos das 
últimas décadas do século $\mathrm{XX}$. Pombo também observa que, enquanto na Biblioteconomia a procura é por "melhores soluções pragmáticas" para a exatidão, facilidade e rapidez no uso da classificação, para o campo filosófico é importante que a classificação esteja em "conformidade com o domínio de objetos classificados". Mas, não seria interessante estabelecer uma divisão rígida entre os dois domínios, pois a visão filosófica pode trazer contribuições para as "[...] elaborações teóricas e técnicas que forem sendo propostas por todos aqueles que se disponham a trabalhar interdisciplinarmente na elaboração científica e técnica de uma ciência da classificação [...]". (POMBO, 1998, p.31-32). A presença desta visão filosófica é importante, considerando-se que toda classificação de documentos é antecedida da classificação de conceitos.

\subsection{Foucault e a formação de conceitos}

Michel Foucault, no capítulo A Formação dos Conceitos de sua obra $A$ Arqueologia do Saber, coloca a possibilidade de os conceitos organizarem-se coerentemente, de forma ordenada e lógica, porém, indica que o contato com a experiência demonstra uma situação um pouco diferente, na qual "“...] o jogo de conceitos que vemos aparecer não obedece a condições tão rigorosas [...]" (FOUCAULT, 2007a, p.62). O edifício conceitual de algumas áreas do conhecimento não se apresenta como uma obra construída tijolo por tijolo, de maneira linear e na qual todas as partes se encaixam simetricamente. Desse modo, é necessário entender como os conceitos se organizam no campo dos enunciados em que surgem e circulam para apenas depois tentar organizá-los em um sistema. Essa organização compreende três momentos ou formas (FOUCAULT 2007 a):

Formas de sucessão: caracterizam-se pelas disposições das séries enunciativas (ordem das narrativas e distribuição dos acontecimentos do tempo na estrutura linear dos enunciados); pelos tipos de correlação dos enunciados (que não são necessariamente idênticos como as correlações entre hipóteses e verificações e as aplicações de leis gerais a universos particulares); e pelos diversos esquemas retóricos de combinação de grupos de enunciados (o encadeamento de descrições e definições na estrutura de um texto). Na história natural da época clássica, por exemplo, os conceitos usados não são os mesmos usados no século XVI. Foucault cita, como exemplo, a modificação no uso dos conceitos de gênero, espécie e sinais e o surgimento de conceitos como os de estrutura e organismo, posteriormente. Afirma, porém, que a 
modificação que determinará o surgimento e a recorrência dos conceitos no século XVII, e para toda a história natural, é a

[...] disposição geral dos enunciados e sua seriação em conjuntos determinados; é a maneira de transcrever o que se observa e de reconstituir, no fio dos enunciados, um percurso perceptivo; é a relação e o jogo de subordinações entre descrever, articular em traços distintivos, caracterizar e classificar; é a posição recíproca das observações particulares e dos princípios gerais; é o sistema de dependência entre o que se aprendeu, o que se viu, o que se deduz, o que se admite como provável, o que se postula. (FOUCAULT, 2007a, p.63).

Segundo Foucault, a história natural dos séculos XVI e XVII não se reduz a uma forma de conhecimento que definiu ou redefiniu conceitos como os de "gênero" e/ou "caráter" ou que introduziu novos conceitos como os de "classificação natural" e de "mamífero"; ela é especialmente caracterizada por uma nova forma de dispor enunciados em conjuntos sequenciais e dependentes, ordenados e sucessivos, nos quais as características e os elementos que se reapresentam de maneira recorrente podem "valer como conceitos".

Formas de coexistência: enquanto as formas de sucessão organizam o campo dos enunciados, as formas de coexistência configuram o campo enunciativo, delineando, segundo Foucault (2007a, p.63), um campo de presença. O campo de presença se configura, nesse caso, pela retomada dos enunciados já formulados em outros momentos e em outras partes em um discurso que procura estabelecer os fundamentos necessários para a busca de verdades e descrições que sejam exatas. No campo de presença os enunciados são dispostos em discursos visando à sua crítica, discussão, julgamento, rejeição e exclusão. Para além da organização dos enunciados, o campo de presença procura verificar o que se pode chamar de premissas dos próprios enunciados no âmbito do discurso. Por isso, Foucault afirma que, nesse campo, as relações podem ser realizadas para a verificação experimental, validações lógicas, repetições e aceitação pela tradição e autoridade. Nas formas de coexistência existe, ainda, o campo da concomitância, no qual os enunciados encontram-se em domínios diferentes e, portanto, em discursos também distintos, mas que, por analogia, por princípios gerais, ou por valerem como modelos, podem ser estudados e confrontados. Dessa maneira,

[...] o campo de concomitância da história natural na época de Lineu e de Buffon se define por um certo número de relações com a cosmologia, história da terra, filosofia, teologia, Escrituras Sagradas e exegese bíblica, matemática (sob a forma bem geral de uma ciência da ordem); e todas estas relações o opõem tanto ao discurso dos naturalistas do século XVI quanto ao dos biólogos do século XIX. (FOUCAULT, 2007a, p.64). 
O domínio de memória é a última instância do campo enunciativo. Nesse domínio estão os enunciados que já não são mais admitidos em determinado discurso, ou seja, aqueles que não são usados para a construção de argumentos visando à comprovação de verdades, mas que funcionam como elos de filiação, de continuidade e descontinuidade histórica.

É assim que o campo de memória da história natural, desde Tournefort, aparece como singularmente estreito e pobre em suas formas, quando o comparamos ao campo de memória, tão amplo, tão cumulativo, tão bem especificado, da biologia, a partir do século XIX; aparece, em compensação, como mais bem definido e articulado que o campo de memória, que envolve, no Renascimento, a história das plantas e dos animais, pois, na época, mal se distinguia do campo de presença: tinha a mesma extensão e a mesma forma e implicava as mesmas relações. (FOUCAULT, 2007a, p.64).

Procedimentos de intervenção: são aplicados aos enunciados, mas não são os mesmos em todas as formações discursivas. Os procedimentos de intervenção podem ser caracterizados pelas técnicas de reescrita que permitem reescrever os enunciados de períodos anteriores dentro de outros esquemas de regras e apresentação. Foucault (2007a, p.65) exemplifica o procedimento com os estudos dos naturalistas do período clássico que reescreveram grupos de enunciados em quadros classificatórios que não apresentam as mesmas leis e grupos de parentesco utilizados na Idade Média e no Renascimento. Existem, ainda, os métodos de transcrição, que utilizam linguagem natural; os modos de tradução, que procuram transformar enunciados quantitativos em qualitativos e vice-versa; os meios de aproximação, que procuram dar maior exatidão aos enunciados; as formas de delimitação (extensão ou restrição), na qual se procura estabelecer domínios específicos onde os enunciados são válidos; a forma pela qual se transfere, ou como se aplica, um enunciado de um campo a outro, como a "[...] transferência da caracterização vegetal à taxonomia animal [...]” (FOUCAULT, 2007a, p.65); os métodos de sistematização, que organizam proposições e enunciados já formulados que se encontram dispersos ou aqueles que já estão relacionados, porém, necessitam de redistribuição, de uma nova composição.

Apesar da heterogeneidade dos elementos que compõem os três momentos ou formas citadas, Foucault (2007a) afirma que a maneira como os diferentes elementos se relacionam permite delimitar grupos de conceitos. Por exemplo, a maneira "[...] pela qual a disposição das descrições ou das narrações está ligada às técnicas de reescrita; a maneira pela qual o campo de memória está ligado às formas de hierarquia e subordinação que regem os enunciados de um texto [...]" (FOUCAULT, 2007a, p.66). O 
sistema de formação conceitual depende e se constitui a partir desse emaranhado de relações.

Por outro lado, Foucault lembra que tal sistema não se limita nem se caracteriza pela descrição direta dos conceitos, pela realização de levantamentos e classificações, pela identificação de traços e características comuns, mas sim pela determinação de esquemas de enunciados relacionados pelo discurso. Não se pode tomar como objeto de análise a estrutura conceitual de um texto isolado, de uma obra ou de uma ciência em determinado momento. A idéia é a análise do discurso que transpassa os diversos momentos dos enunciados. Ou seja, os esquemas propostos por Foucault (2007a, p.66) não se referem à determinação da ordem exata do conceito, à construção interna ou à sua gênese individual, mas à sua “[...] dispersão anônima através dos textos, livros e obras; dispersão que caracteriza um tipo de discurso e que define, entre os conceitos, formas de dedução, de derivação, de coerência, e também de compatibilidade, de entrecruzamento [...]", etc. Esse nível de análise proposta corresponde, segundo Foucault, a um nível pré-conceitual.

Como exemplo do que chama pré-conceitual, Foucault (2007a) utiliza quatro esquemas teóricos (atribuição, articulação, designação e derivação) da gramática geral dos séculos XVII e XVIII, analisados em sua obra As Palavras e as Coisas (FOUCAULT, 2007b). "O nível pré-conceitual que assim destacamos não remete nem a um horizonte de idealidade nem a uma gênese empírica das abstrações", mas a um nível

[...] do próprio discurso, que não é mais tradução exterior, mas lugar de emergência dos conceitos; não associamos as constantes do discurso às estruturas ideais do conceito, mas descrevemos a rede conceitual a partir das irregularidades intrínsecas do discurso; não submetemos a multiplicidade das enunciações à coerência dos conceitos, nem esta ao recolhimento silencioso de uma idealidade metaistórica; estabelecemos uma série inversa: recolocamos as intenções livres de não-contradição em um emaranhado com as regras que caracterizam uma prática discursiva. (FOUCAULT, 2007a, p.68).

O nível pré-conceitual, portanto, situa seu conjunto de regras em níveis de superfície, ou seja, em níveis do discurso não enraizados no fundo longínquo da própria história. Assim, não se está falando da gênese de abstrações e operações para constituílas, nem de intuições, técnicas e definição de estruturas formais; também não se está falando de regras de formação em nível mental ou da consciência.

Dessa perspectiva, as regras de formação de conceitos não podem ser generalizadas ou universalizadas para diversos ou todos os domínios de maneira 
indiscriminada; elas ocorrem em campos discursivos definidos e não há como estabelecer suas possibilidades de extensão com antecedência. O que pode ser feito são comparações entre uma região e outra das regras de formação de conceitos, procurando identificar suas identidades e diferenças. O exemplo de Foucault para a questão reside justamente na análise da gramática geral e da história natural da época clássica, citadas acima.

Foucault conclui que as regras de formação dos conceitos não são o resultado depositado e sedimentado na história e em hábitos coletivos, nem “[...] constituem o esquema descarnado de todo um trabalho obscuro, ao longo do qual os conceitos se teriam mostrado através de ilusões, preconceitos, erros, tradições”. Ao contrário, o nível pré-conceitual permite que "[...] apareçam as irregularidades e coações discursivas que tornaram possível a multiplicidade heterogênea dos conceitos [...]”. (FOUCAULT, 2007a, p.69-70).

O que se pode perceber é que no domínio da formação dos conceitos, baseada na análise das formações discursivas e de enunciados, há um desligamento do léxico (das palavras), do mentalismo (cognição e psicologia) e das experiências e experimentações (empirismo). A formação de conceitos em tal perspectiva são ações incessantes de reconstrução, re-escrituras, ou seja, de um formar e reformar pontos de vista não sobre um objeto, uma coisa ou um referente, mas sobre discursos, enunciados e conceitos.

Eu compreendo que a conceituação não deveria estar fundada numa teoria do objeto - o objeto conceituado não é o único critério de uma boa conceituação. Temos que conhecer as condições históricas que motivam nossa conceituação. Necessitamos de uma consciência histórica da situação presente. (FOUCAULT, 1995, p.232).

Foucault não parece, portanto, preocupado com a identidade dos enunciados e com os atos discursivos individuais; também não se interessa pela pragmática discursiva de contextos locais; seu foco está "[...] justamente naqueles tipos de atos discursivos que estão separados da situação local de asserção e do fundamento do dia-a-dia a fim de constituir um campo relativamente autônomo" (DREYFUS; RABINOW, 1995, p.53).

Outra questão desconsiderada por Foucault em seu método, segundo Dreyfus e Rabinow (1995), é a seleção e a classificação dos atos discursivos de maneira tradicional. Por outro lado, é necessário trabalhar como um empirista para a seleção de dados brutos de um dado período para depois sistematizar tais dados de maneira independente. 
Em resumo, a seleção e a classificação do corpus de enunciados já foi realizada por "arquivistas", baseados em suas próprias práticas discursivas, mas Foucault não considera "[...] este conjunto original de enunciados nem a classificação concomitante em disciplinas como algo que tenha um valor em si [...]" (DREYFUS; RABINOW, 1995, p.66). Os autores referem-se, provavelmente, aos bibliotecários que organizam e classificam os acervos de bibliotecas. Além de "arquivista" também utilizam o termo "curador" como referência às pessoas que classificam um determinado corpus discursivo. Pode-se inferir que o chamado corpus discursivo é o acervo de uma biblioteca, classificado por meio de listas de classificação hierárquicas e alfanuméricas, como mostra o trecho a seguir:

Foucault propõe começar como um empirista puro, selecionando como dados brutos um conjunto daquilo que era considerado atos discursivos sérios durante um dado período. (Provavelmente, a tarefa de pré-seleção foi realizada pelos curadores da Biblioteca Nacional. O fato de os arquivistas já terem tomado uma decisão sobre o que é sério e terem aplicado sua própria classificação ao corpus resultante, baseados em suas práticas discursivas e não-discursivas, não constitui problema para Foucault. O arqueólogo não considera este conjunto original de enunciados nem a classificação concomitante em disciplinas como algo que tenha um valor em si; ao contrário, os enunciados apenas fornecem os dados brutos para uma sistematização independente). (DREYFUS; RABINOW, 1995, p.66).

Para Foucault as "[...] unidades tradicionais fracassam até mesmo em seus próprios termos. Ele observa que não há característica essencial a nenhuma disciplina, definida pela maneira tradicional, que permaneça a mesma durante a evolução" (DREYFUS; RABINOW, 1995, p.66). As disciplinas, segundo os autores, não descrevem de maneira definitiva seus objetos e suas descrições não têm, muitas vezes, duração longa.

A própria idéia de formação e classificação de enunciados fica mais clara quando Foucault, e antes dele Wittgenstein, identificam, de acordo com Dreyfus e Rabinow (1995, p.66), que não se classifica “[...] objetos, sejam eles cadeira e jogos ou botânicos e físicos, identificando uma essência ou uma lista de aspectos essenciais". Na realidade, o que é percebido com antecedência, segundo Wittgenstein, é "“[...] 'uma rede densa de semelhanças que se recortam e se imbricam umas nas outras: são ora semelhanças gerais, ora semelhanças particulares" (WITTGENSTEIN, $1953^{33}$ apud DREYFUS; RABINOW, 1995, p.66). Como já apresentado anteriormente, para Wittgenstein, os

\footnotetext{
${ }^{33}$ WITTGENSTEIN, Ludwig. Philosophical Investigations. Oxford: Basil Blackwell Publishers, 1953. p.32-49.
} 
conceitos são como um "fio de fibras", onde a força de um fio não reside em sua extensão, mas na quantidade de relações e "entrecruzamentos" que tem com outras fibras.

É importante reforçar, a partir da perspectiva de Foucault, que os conceitos não podem ser considerados invariáveis. É possível verificar, segundo Dreyfus e Rabinow (1995, p.78), que os conceitos se “[...] transformam, se recortam de forma incompatível e são todos submetidos às revoluções conceituais".

A discussão sobre a formação dos conceitos não era questão prioritária para Foucault. Apesar da riqueza de exemplos e contra-exemplos, concorda-se com Dreyfus e Rabinow (1995, p.78-79) que afirmam que os princípios explicativos de Foucault (na questão da formação dos conceitos) são "flutuantes" e que ele é mais claro quando descreve os argumentos que rejeita do que os argumentos que defende.

Mas, é importante considerar o aspecto metodológico (arqueológico) que Foucault (2007a) explora para a formação de conceitos. Como vimos, a organização do campo dos enunciados, onde os conceitos se formam e circulam, é composta por diversas formas ou maneiras (formas de sucessão, formas de coexistência e procedimentos de intervenção) e sua análise passa pela heterogeneidade de seus elementos.

Essa heterogeneidade é explícita na própria abordagem de Foucault (2007a; 2007b) e seu caráter "flutuante" é necessário para a ordem de seu próprio discurso. O caráter pré-conceitual, nesse caso, é uma forma de delimitar um discurso sem definir uma unidade lexical (palavra) ou um enunciado pragmático ou lógico, ou seja, um relacionamento de idéias explícitas e implícitas em enunciados e não a (de)limitação das características essenciais de um conceito (termo/palavra).

2.6 Deleuze e Guattari: apenas a filosofia cria conceitos

Na obra $O$ que é a Filosofia?, Gilles Deleuze e Félix Guattari desenvolvem um escrito de maturidade, uma obra, segundo os autores, que apenas a "velhice" dá condições soberanas de "liberdade" para realizá-la. Os autores se sentem à vontade para fazer a pergunta “O que é a Filosofia?" e a resposta, ao invés de uma sequência linear de teorias do conhecimento e de pensadores que se apresentam ao longo da história, é a apresentação da filosofia como "[...] a arte de formar, de inventar, de fabricar conceitos.” (DELEUZE; GUATTARI, 2004, p.10). 
Deleuze e Guattari (2004) dividem a abordagem do conceito em duas partes: I. Filosofia (que contempla a questão-chave "O que é um Conceito?"; "O Plano de Imanência"; "Os Personagens Conceituais" e "Geo-filosofia") e II. Filosofia, Ciência Lógica e Arte (contemplando "Functivos e Conceitos"; "Prospectos e Conceitos"; "Percepto, Afecto e Conceito"; e a conclusão "Conclusão - Do caos ao Cérebro"). Nossa intenção não é resenhar este livro, mas consideramos importante descrever a ordem de seus capítulos para demonstrar que os autores analisam, comparam e discutem a idéia de conceito em filosofia e a noção de conceito que identificam em outras áreas como as ciências e as artes.

Se a Filosofia é a arte de "formar, de inventar, de fabricar conceitos", o filósofo é diretamente responsável por essa arte. "O filósofo é bom em conceitos, ele sabe quais são inviáveis, arbitrários ou inconsistentes, não resistem um instante, e quais, ao contrário, são bem feitos e testemunham uma criação, mesmo se inquietante ou perigosa". Mesmo assim, como "amigo" do conceito, o filósofo também é potencialmente um conceito e a Filosofia não apenas forma, inventa ou fabrica conceitos, mas ela é a disciplina responsável por criar conceitos sendo seu objeto a criação de novos conceitos (DELEUZE E GUATTARI, 2004, p.11-13).

Porém, os autores afirmam que as artes e as ciências também são criadoras de conceitos, embora apenas a filosofia o faça em sentido "estrito". Assim

[...] os filósofos não devem mais contentar-se em aceitar os conceitos que lhes são dados, para somente limpá-los e fazê-los reluzir, mas é necessário que eles comecem por fabricá-los, criá-los, afirmá-los, persuadindo os homens a utilizá-los. Até o presente momento, tudo somado, cada um tinha confiança em seus conceitos, como num dote miraculoso vindo de algum mundo igualmente miraculoso [...]. (NIETZSCHE ${ }^{34}$ apud DELEUZE; GUATTARI, 2004, p.13-14).

Um filósofo que não seja capaz de criar seus próprios conceitos, segundo os autores, não teria "valor". A idéia de criação como fundamento básico à filosofía não deve ser confundida com a contemplação, com a reflexão e nem com a comunicação. "A filosofia não contempla, não reflete, não comunica, se bem que ela tenha de criar conceitos para estas ações ou paixões" (DELEUZE E GUATTARI, 2004, p.15). A contemplação, a reflexão e a comunicação servem para construir Universais de domínio sobre outras disciplinas, exaltando o idealismo explícito da filosofia em ser a disciplina

\footnotetext{
${ }^{34}$ NIETZSCHE, Posthumes 1884-1885, Oeuvres philosophiques, XI, Gallimard, pp.215-216 (sobre "a arte da desconfiança").
} 
das disciplinas. Já o caráter singular da criação de conceitos coloca a filosofia em um plano de explicação dos próprios Universais.

Toda criação é singular, e o conceito como criação propriamente filosófica é sempre uma singularidade. $O$ primeiro princípio da filosofia é que os Universais não explicam nada, eles próprios devem ser explicados (DELEUZE; GUATTARI, 2004, p.15).

Apesar de os autores afirmarem que nem mesmo o conhecimento é possível a uma pessoa se ela mesma não tiver criado seus próprios conceitos, isto não dá à Filosofia total exclusividade sobre a criação e sobre o pensamento, pois, existem "[...] outras maneiras de pensar e de criar, outros modos de ideação que não têm que passar por conceitos, como o pensamento científico" (DELEUZE, GUATTARI, 2004, p.15-17). Mesmo se lhe for atribuído outro nome, a Filosofia é e sempre será o lugar de criação dos conceitos.

Para Deleuze e Guattari, outras áreas, como as ciências do homem e a sociologia (também a epistemologia, a lingüística, a psicanálise e a lógica), começaram a se interessar pelo conceito, não como criação, mas como elemento de concepção e representação coletivas. Porém, "Enfim, o fundo do poço da vergonha foi atingido quando a informática, o marketing, o design, a publicidade, todas as disciplinas da comunicação apoderaram-se da própria palavra conceito e disseram: é nosso negócio, somos nós os criativos, nós somos os conceituadores!" (DELEUZE; GUATTARI, 2004, p.19. Grifo dos autores).

Mas, na perspectiva de Deleuze e Guattari, o que é, na realidade, um conceito? Toda definição de um conceito depende da definição de seus próprios componentes. Um conceito é formado por um conjunto de elementos que isolados não fazem sentido, mas ganham forma e conteúdo quando reunidos. A reunião desses elementos em torno de uma questão é o início de um conceito. Início, por que não basta apenas reunir alguns componentes ou algumas características para se formar um conceito; ao contrário, é necessário que tais elementos e características sejam alocados e usados de maneira que evidenciem um ou vários traços exclusivos daquele conceito. Da mesma maneira que alguns componentes unem os conceitos, estes também os distinguem e lhes dão identidade.

“Não há conceito simples", dizem Deleuze e Guattari (2004, p.27). Os conceitos são formados por multiplicidades, mas as multiplicidades nem sempre são conceitos. Também não existem conceitos que sejam formados por um único componente. Mesmo 
o conceito primeiro, o conceito pelo qual a Filosofia ou uma filosofia começa, não possui apenas um único componente. O cogito de Descartes, por exemplo, é um conceito que forma uma filosofia, mas que não é unicamente formado por ela. Ou seja, o conceito de cogito cartesiano não é formado por um único componente, ao contrário, é formado por uma série de outros elementos que já estavam no conceito ou que foram recortados de um universo conceitual mais amplo.

Nesse sentido,

Todo conceito é ao menos duplo, ou triplo, etc. Também não há conceito que tenha todos os componentes, já que seria um puro e simples caos: mesmo os pretensos universais, como conceitos últimos, devem sair do caos circunscrevendo um universo que os explica (contemplação, reflexão, comunicação...). Todo conceito tem um contorno irregular, definido pela cifra de seus componentes. É por isso que, de Platão a Bergson, encontramos a idéia de que o conceito é questão de articulação, corte e superposição. É um todo, porque totaliza seus componentes, mas um todo fragmentário. É apenas sob essa condição que pode sair do caos mental, que não cessa de espreitá-lo, de aderir a ele, para reabsorvê-lo (DELEUZE; GUATTARI, 2004, p.27).

Pode-se observar que os conceitos estão sempre em processos dinâmicos de recomposição e articulação, margeando uma situação caótica ou surgindo dela. O caos mental é uma situação necessária que ameaça constantemente a criação de um conceito e, ao mesmo tempo, é garantia de criação e articulação. A irregularidade no contorno de um conceito não é um defeito, nem mesmo o elo que poderá ligá-lo, indiretamente, a outro conceito.

Os conceitos, como se verá adiante, não são peças com contornos precisos que se encaixam perfeitamente a outros conceitos como num quebra-cabeças. São pedaços, fragmentos com arestas pontiagudas, sem contornos definidos, que permitem a dinâmica da articulação e da recomposição dentro de grandes mosaicos ressonantes. $\mathrm{O}$ todo conceitual não se articula com outro todo conceitual, porém, os fragmentos dos conceitos são a base de uma relação contemplativa e reflexiva.

Buscar a organização do caos mental é traçar paralelos e tentar articular fragmentos (as fibras, os traços já referidos desde o início desta pesquisa), ou seja, o processo de criação de conceitos não é um processo de agrupamento de características harmônicas dos conceitos, mas sim um jogo reflexivo constante que procura defender uma perspectiva particular. Nossas opiniões e argumentações são os princípios de tais perspectivas. Se não concordamos com a opinião de um outro, buscamos o confronto de duas formas: seguindo a mesma linha de raciocínio do outro, mas sacando fragmentos 
distintos no mesmo trajeto; ou seguindo um outro trajeto, mas atentos aos fragmentos que possam sustentar nossa argumentação e chegar ao ponto que queremos defender. $\mathrm{Na}$ realidade, este é um princípio que pode ser aproximado às metodologias de construção de mapas conceituais, onde não há uma ordenação lógica dentro de cadeias de universais, mas uma construção aparentemente fragmentária que faz sentido dentro de um argumento particular.

Argumentos particulares podem remeter a outros mundos possíveis. Mundos que podem ser construídos pela linguagem, pela fala. A criação de conceitos é, também, a criação de mundos possíveis. A história da criação dos mundos possíveis é longa e passa pelos filósofos antigos e modernos e pelas clássicas correntes nominalistas e realistas. Da mesma maneira, os conceitos também têm história, “[...] embora a história se desdobre em ziguezague, embora cruze talvez outros problemas ou outros planos diferentes" (DELEUZE; GUATTARI, 2004, p.29).

Os conceitos não se definem apenas pela sua história. Um conceito, segundo Deleuze e Guattari (2004, p.30), apresenta também um “[...] devir que concerne, desta vez, à sua relação com conceitos situados no mesmo plano". Nesse sentido, um conceito não está em relação a outro que o precedeu ou que irá sucedê-lo, em diferentes planos. Os conceitos com diferentes histórias se encontram e se relacionam em distintas regiões de um mesmo plano. Não há ligação explicitamente lógica que possa conectar um conceito a outro. O devir conceitual ocorre no campo da percepção. Deleuze e Guattari (2004, p.30) chamam de Outrem a condição para toda percepção, ou seja, uma condição na qual estão o "eu" e o outro. "Outrem é sempre percebido como um outro, mas, em seu conceito, ele é a condição de toda percepção, para os outros como para nós”. No plano do Outrem podemos ver a nós mesmos como duplos, como triplos, assim como os componentes dos próprios conceitos.

O exemplo acima parece complexo, dizem os autores, mas qualquer tentativa de abordagem do conceito de conceito levará às mesmas dificuldades e complexidades, pois, um conceito não remete a outro apenas em uma linha ou contexto histórico, mas também em seu próprio devir. Os conceitos criam-se a partir deles mesmos e cada um de seus componentes são conceitos potenciais. A impressão que isso causa é a de infinito. De fato, os conceitos são finitos e determinados, mas o seu plano de criação é infinito. 
Cada conceito tem componentes que podem ser, por sua vez, tomados como conceitos (assim Outrem tem o rosto entre seus componentes, mas o Rosto, ele mesmo, será considerado como conceito, tendo também componentes). Os conceitos vão, pois, ao infinito e, sendo criados, não são jamais criados do nada. Em segundo lugar, é próprio do conceito tornar os componentes inseparáveis nele: distintos, heterogêneos e todavia não separáveis, tal é o estatuto dos componentes, ou que define a consistência do conceito, sua endo-consistência. (DELEUZE; GUATTARI, 2004, p.31. Grifos dos autores).

A endo-consistência do conceito é a sua garantia de identidade. São os componentes internos que, em sua distinção característica, possuem um ponto, uma zona de cobertura, um campo de relação com outros conceitos internos. Interromper os pontos de convergência e ligação entre os componentes de um conceito significa destituí-lo de sentido: “[...] há um domínio $a b$ que pertence tanto a $a$ quanto a $b$, em que $a$ e $b$ 'se tornam' indiscerníveis. São estas zonas, limites ou devires, esta inseparabilidade, que definem a consistência interior do conceito" (DELEUZE; GUATTARI, 2004, p.32).

Sendo a endo-consistência a garantia de relação, de identificação de zonas características e indissociáveis internas ao conceito, a exo-consistência garante a relação externa do conceito com outros conceitos. As relações externas ocorrem por meio de "pontes" construídas em um mesmo plano conceitual. Os contornos irregulares dos conceitos, suas arestas, são responsáveis pelas zonas de convergência externas.

O traço intensivo, não sendo geral nem particular, percorre os componentes do conceito e, em um universo ordenado, se relaciona por meio de variações influenciadas por outros conceitos "vizinhos".

Um conceito é uma heterogênese, isto é, uma ordenação de seus componentes por zonas de vizinhança. É ordinal, é uma intensão presente em todos os traços que o compõem. Não cessando de percorrê-los segundo uma ordem sem distância, o conceito está em estado de sobrevôo com relação a seus componentes. Ele é imediatamente co-presente sem nenhuma distância de todos os seus componentes ou variações, passa e repassa por eles: é um ritornelo, um opus com sua cifra (DELEUZE; GUATTARI, 2004, p.32-33. Grifos dos autores).

As definições propostas por Deleuze e Guattari situam-se, eminentemente, no plano filosófico. Apesar do jogo de palavras usado sempre que se referem diretamente ao conceito, como incorporal mas corpóreo, sem coordenadas mas ordenado, não possui energia mas é intenso, é finito mas infinito, absoluto mas relativo, os autores afirmam que:

- os conceitos não dizem uma essência ou uma coisa, mas um 
acontecimento;

- no plano filosófico os conceitos são constantemente remanejados e mudados;

- o conceito é definido pela sua endo e exo-consistência, mas não tem uma referência, ele é auto-referencial;

- o conceito não é discursivo, pois a própria filosofia não se forma no discurso, em proposições.

Tomando a idéia de não discursividade do conceito, Deleuze e Guattari (2004, p.34) afirmam que não há conceitos científicos.

O conceito não é discursivo, e a filosofia não é uma formação discursiva, porque não encadeia proposições. É a confusão do conceito com a proposição que faz acreditar na existência de conceitos científicos, e que considera a proposição como uma verdadeira 'intensão' (o que a frase exprime): então o conceito filosófico só aparece, quase sempre, como uma proposição despida de sentido. Esta confusão reina na lógica, e explica a idéia infantil que ela tem da filosofia. Medem-se os conceitos por uma gramática 'filosófica' que os substitui por proposições extraídas das frases onde eles aparecem: somos restringidos sempre a alternativas entre proposições, sem ver que o conceito já foi projetado no terceiro excluído. O conceito não é, de forma alguma, uma proposição, não é proposicional, e a proposição não é nunca uma intensão. As proposições definem-se por sua referência, e a referência não concerne ao Acontecimento, mas a uma relação com o estado de coisas ou de corpos, bem como às condições desta relação. (DELEUZE; GUATTARI, 2004, p.34-35. Grifo dos autores).

Os conceitos não precisam de proposições para figurarem no âmbito do sentido, pois, seus próprios componentes, que também são conceitos, se relacionam com os componentes de outros conceitos. Ou seja, há um ambiente de "vibração" intensa entre os próprios conceitos e seus componentes sem, necessariamente, comporem uma estrutura gramatical, ou proposicional, seqüencial e coordenada. Não há razão para que um conceito dê sequência a outro, dizem os autores. Os conceitos são fragmentos que não se correspondem diretamente como peças de um quebra-cabeças; os conceitos e seus componentes ressoam uns nos outros.

Para Deleuze e Guattari, portanto, não existem conceitos científicos, mas proposições parciais. Se os conceitos não são proposições e a ciência se baseia em proposições, não há conceitos científicos. Para os autores a questão está no campo da enunciação. A enunciação ocorre antes, ela é exterior à proposição. No campo filosófico, a enunciação ocorre sobre os conceitos fragmentários e, no campo científico, a enunciação ocorre sobre proposições parciais. 
Existem dois tipos de enunciação: a enunciação de posição, que é imanente ao conceito, pois acontece no próprio conceito e seus componentes; e a enunciação de criação ou de assinatura, que se vincula às proposições científicas, mas também fazem parte do campo filosófico, pois os conceitos filosóficos também são "assinados" (teorema de Pitágoras, o cogito de Descartes, etc). Mas, para Deleuze e Guattari (2004, p.36), os nomes próprios vinculados à enunciação são “[...] máscaras para outros devires, servem somente de pseudônimos a entidades singulares mais secretas". Da mesma forma, para os autores as proposições constituem "[...] observadores parciais extrínsecos, cientificamente definíveis com relação a tal ou tais eixos de referência, ao passo que, para os conceitos, são personagens conceituais intrínsecos [...]" no plano da consistência.

Por enquanto, dispomos apenas de uma hipótese muito ampla: das frases ou de um equivalente, a filosofia tira conceitos (que não se confundem com idéias gerais ou abstratas), enquanto que a ciência tira prospectos (proposições que não se confundem com juízos), e a arte tira perceptos e afectos (que também não se confundem com percepções ou sentimentos). Em cada caso, a linguagem é submetida a provas e usos incomparáveis, mas que não definem a diferença entre as disciplinas sem constituir também seus cruzamentos perpétuos. (DELEUZE; GUATTARI, 2004, p.37. Grifos dos autores).

Há uma outra distinção proposta pelos autores: conceitos, prospectos e perceptos. Os prospectos seriam para a ciência o que são os conceitos para a Filosofia, mas sem as condições de criação e endo e exo-consistência desta última, o mesmo valendo para os perceptos na arte.

Num segundo momento, chamado "Filosofia, Ciência Lógica e Arte", Deleuze e Guattari, exemplificam melhor a questão distinguindo functivos e conceitos no campo da ciência, prospectos e conceitos no campo da lógica e percepto, afecto e conceito no campo das artes.

Os chamados functivos, segundo Deleuze e Guattari, são próprios da ciência. A ciência é definida e determinada por funções e proposições. As funções são os functivos. São elas que determinam o que é ou não ciência e é por meio da função que ocorrem a comunicação e a reflexão na ciência. Os conceitos filosóficos permeiam as funções científicas e também podem adotar como componentes os functivos, mas não são, necessariamente, científicos. A necessidade de trabalhar com unidades e múltiplos finitos é o que limita a ciência às funções, pois ela precisa estabelecer uma ordem e um limite ao caos, atuando por meio de um conjunto coordenado de endo e exo-referências. 
A filosofia opera em meio ao caos e à sensação de infinito. São eles que dão condições às variações e às dinâmicas incessantes dos componentes e das partículas conceituais. Nesse sentido, segundo Deleuze e Guattari (2004, p.154-157), o plano de referência (sem consistência), necessário à ciência, contrasta e se diferencia do plano de imanência ${ }^{35}$ (consistente e sem referência) filosófico.

Já os prospectos são situados, por Deleuze e Guattari (2004, p.179-180), no campo da Lógica. A operação, por meio da lógica, dos functivos científicos origina os prospectos. Na Lógica, os conceitos tomam o caráter de proposições, perdendo suas características de conceitos filosóficos, como a auto-referência e a endo e exoconsistência. Assim, a Lógica tenta substituir ou absorver a Filosofia e confunde a abordagem sobre o conceito.

Confundindo os conceitos com funções, a lógica faz como se a ciência se ocupasse já com conceitos, ou formasse conceitos de primeira zona. Mas ela própria deve dobrar as funções científicas com funções lógicas, que, se supõe, formam uma nova classe de conceitos puramente lógicos, ou de segunda zona. É um verdadeiro ódio que anima a lógica, na sua rivalidade ou sua vontade de suplantar a filosofia. Ela mata o conceito duas vezes. Todavia o conceito renasce, porque não é uma função científica, e porque não é uma proposição lógica: ele não pertence a nenhum sistema discursivo, não tem referência. O conceito se mostra, e nada mais faz que se mostrar. Os conceitos são monstros que renascem de seus pedaços. (DELEUZE; GUATTARI, 2004, p.183).

$\mathrm{Na}$ arte existem os chamados perceptos e afectos. Sua condição de referencialidade os distancia do conceito filosófico, mas sua autonomia com relação ao vivido permite o desenvolvimento de um sentido em si, sem a necessidade do homem como elemento que imprime um grau de percepção ou de afecção à uma obra de arte, por exemplo. Os perceptos e os afectos já estão presentes na composição da obra de arte.

Na mesma perspectiva da citação anterior, mas especificando a função na lógica, nas ciências e nas artes, afirmam:

\footnotetext{
${ }^{35} \mathrm{O}$ plano de imanência é o plano onde os conceitos ressoam, mas a ressonância dos conceitos é excedida e não é a única correspondente entre os conceitos e o plano. O plano de imanência é único e ilimitado, infinito, que não se confunde com os próprios conceitos. "Os conceitos são como as vagas múltiplas que se erguem e que se abaixam, mas o plano de imanência é a vaga única que os enrola e os desenrola." (DELEUZE; GATTARI, 2004, p.51). Segundo Deleuze e Gattari (2004, p.56-57) a filosofia pode começar pela criação de conceitos e, nesse sentido, o plano de imanência é pré-filosófico, remetendo a uma compreensão não-conceitual, a um estado intuitivo. Caracterizados, respectivamente, por traços diagramáticos e traços intensivos, o plano de imanência é intuitivo enquanto que o conceito é intensivo. Além do capítulo "Plano de Imanência" de Deleuze e Gattari (2004), ver também a análise sobre conceitos e planos de imanência de Schöpke (2004).
} 
A confusão do conceito com a função é ruinosa sob vários aspectos para o conceito filosófico. Ela faz da ciência o conceito por excelência, que se exprime na proposição científica (o primeiro prospecto). Ela substitui o conceito filosófico por um conceito lógico, que se exprime nas proposições de fato (segundo prospecto). Ela deixa ao conceito filosófico uma parte reduzida ou degenerada, que ela se reserva no domínio da opinião (terceiro prospecto), servindo-se de sua amizade por uma sabedoria superior ou uma ciência rigorosa. Mas o conceito não tem seu lugar em nenhum destes três sistemas discursivos. O conceito não é uma função do vivido, nem uma função científica ou lógica. A irredutibilidade dos conceitos às funções só se descobre se, ao invés de confrontá-las de maneira indeterminada, se compara o que constitui a referência de umas e o que faz a consistência de outras. Os estados de coisas, os objetos ou corpos, os estados vividos formam as referências de função, ao passo que os acontecimentos são a consistência de conceito (DELEUZE; GUATTARI, 2004, p.195. Grifos dos autores).

Em outro momento, excluindo a Lógica, os autores indicam a arte, a ciência e a filosofia como as "três grandes formas do pensamento".

O que define o pensamento, as três formas do pensamento, a arte, a ciência e a filosofia, é sempre enfrentar o caos. Mas a filosofia quer salvar o infinito, dando-lhe consistência: ela traça um plano de imanência, que leva até o infinito acontecimentos ou conceitos consistentes, sob a ação de personagens conceituais. A ciência, ao contrário, renuncia ao infinito para ganhar a referência: ela traça um plano de coordenadas somente indefinidas, que define sempre estados de coisas, funções ou proposições referenciais, sob a ação de observadores parciais. A arte quer criar um finito que restitua $o$ infinito: traça um plano de composição que carrega por sua vez monumentos ou sensações compostas, sob a ação de figuras estéticas. (DELEUZE; GUATTARI, 2004, p.253).

Deleuze e Guattari fazem a defesa da filosofia por meio do que chamam as "três grandes formas de pensamento". Portanto, os autores não eliminam a arte, a ciência e a lógica do universo do pensamento. Antes, elegem a Filosofia como a disciplina máxima do campo do conhecimento, argumentando que apenas esta última é capaz de criar conceitos. As outras operam por meio de funções, proposições, discursos, perceptos e afectos. Por outro lado, também dizem que conceito é conhecimento, fazendo crer que apenas a Filosofia cria conhecimento, pois apenas a ela é dada a capacidade de criar conceitos. Apesar da extensa argumentação de Deleuze e Guattari, pode-se indagar: as funções, os perceptos e afectos não poderiam ser considerados tipos de conceitos?

\subsection{Conceitos filosóficos e científicos: Gilles-Gaston Granger}

Na obra Por um conhecimento filosófico, Gilles-Gaston Granger explora os conceitos na ciência e na filosofia. Como Deleuze e Guattari (2004), Granger (1989) coloca os conceitos em questão. Procura não apenas distinguir o conhecimento 
filosófico do conhecimento científico, mas, também, esclarecer que a filosofia pode ser uma forma de conhecimento válido, sem ser ciência.

Diante da pergunta "Como pode a filosofia ser um conhecimento?", sem ser ciência e sem estabelecer relação direta com o uso transcendental da razão, Granger (1989) propõe uma forma de análise para distinguir conhecimento filosófico de conhecimento científico.

A ciência constrói modelos abstratos dos fenômenos, a filosofia não. A ciência procura explicar fatos e define os objetos de análise em algum ponto da realidade, a filosofia não explica fatos e nem possui objetos. Para Granger (1989, p.14) a filosofia tem uma "intenção oculta" que se manifesta não na organização de fatos, mas na organização de significações. Também a filosofia não é uma das "belas artes"; caso o fosse, só poderia ser uma arte da linguagem em estado puro, como a dos poetas e romancistas. A filosofia não usa a linguagem para formar conceitos diretamente, nem para criar objetos, mesmo que os objetos sejam fruto da imaginação ou da experiência sensível, como ocorre nas artes. A distinção que o autor faz fundamenta um dos argumentos principais de seu livro: os conceitos filosóficos não podem ser reduzidos às artes e às ciências.

Por outro lado, Granger (1989, p.18) afirma que o filosofar é uma arte, pois a filosofia só existe em ato. $\mathrm{O}$ mesmo não pode ser dito em relação à ciência, já que as idéias científicas apenas ocorrem quando são realizadas, postas em execução, com objetivos empíricos. A ciência procura estabelecer relação de neutralidade com o leitor, o que não é o caso da filosofia. O filósofo usa a linguagem para "codificar noções" e procura esclarecer para o leitor quais são suas regras de codificação, mas “[...] no uso particular que faz da língua e nas escolhas que opera entre aquilo que na experiência, significa ou não significa, aparece uma espécie de supercodificação, que cabe ao leitor decifrar, num jogo aberto de interpretação [...]” (GRANGER, 1989, p.19).

O conhecimento filosófico, ao interpretar uma experiência (de um grupo ou de um homem) marcada e datada historicamente, a transforma, segundo Granger (1989, p.21. Grifo do autor), em uma "[...] figura intemporal de uma consciência formulada através de conceitos, não como figura fugaz das suas condições históricas”. Por meio de conceitos, experiências passadas chegam até os dias atuais como formas de construção do conhecimento e plenas de significado. Grosso modo, isso quer dizer que as 
experiências passadas, expressas por conceitos, continuam a significar em tempos diversos, inclusive nos atuais, não se perdendo e muito menos sendo totalmente superadas por experiências mais recentes.

De forma distinta do conhecimento filosófico, o conhecimento científico é conhecimento de objetos. Ao contrário de Deleuze e Guattari (2004) que desqualificam a ciência como criadora de conceitos, Granger (1989, p.161) reconhece que a representação científica se dá por meio de conceitos, mas se pergunta se é necessário restringir os conceitos à representação de objetos. Semelhante restrição faria da filosofia um discurso sobre o vivido e não sobre as experiências do vivido, representando-o por "afetos ou imagens" e não por meio de conceitos.

A questão principal a ser levantada não é a de saber se um conceito científico ou filosófico é possível, mas sim de saber se um conhecimento sem objetos é possível:

Todo conceito, qualquer que seja seu campo de aplicação, apresenta-se necessariamente como uma certa espécie de representação de um vivido num sistema de símbolos. Mas, para que uma representação seja conceitual, é preciso que ofereça ao pensamento uma articulação operatória. (GRANGER, 1989, p.162. Grifos do autor).

Na ciência, a condição operatória está ligada ao objeto, mas isso não é possível na filosofia, pois ela não possui objeto. Para a filosofia, a natureza operatória dos conceitos relacionados a objetos não seria possível, mas, segundo Granger (1989, p.163), ela poderia substituir o caráter operatório do conceito pela redução a "[...] uma articulação dada, imediata, imposta, do vivido."

Para a fenomenologia, os conceitos são representações imediatas da consciência. Desse ponto de vista, os conceitos são produzidos por descrição e não tanto por construção. Mas, para Granger, o problema maior da abordagem fenomenológica está na idéia de configuração imanente da consciência, que leva as "tarefas de análise descritiva" ao plano da intuição, por sua vez distinta de uma "abordagem empírica dos fatos de consciência".

Diante da tese fenomenológica, sem diminuir o valor de sua abordagem, é necessário, diz Granger (1989, p.164. Grifos do autor), reconhecer uma conclusão negativa: "[...] que é preciso, de qualquer sorte, inverter a palavra de ordem do 'voltar às coisas mesmas' e reconhecer que os conceitos filosóficos são, com relação aos conceitos 'naturais' da percepção, da técnica e da ciência, metaconceitos". O termo metaconceito serve para reforçar que os conceitos filosóficos não visam ao vivido, não o designam e 
também não procuram “[...] representá-lo absolutamente pela mediação das estruturas, isto é, por exemplo, relações de conjunto entre objetos". A função dos metaconceitos é “[...] fornecer pontos de apoio para uma linguagem que quer falar dos conceitos naturais, descobrindo seu 'sentido', isto é, construindo sua organização totalizante". Ou seja, a filosofia constrói metaconceitos usados para falar de outros conceitos (não filosóficos). Os metaconceitos são os referenciais substantivos de apoio e crítica de qualquer linguagem.

Por outro lado, é o próprio Granger que se adianta e tenta esclarecer que a "hipótese" dos metaconceitos não se encaixa na doutrina neopositivista de crítica formal da linguagem.

Se o fato de a ciência se constituir como 'língua bem feita' não deve conduzir necessariamente ao nominalismo, o fato de que o conceito filosófico seja, em certo sentido, um metaconceito, não nos obriga a definir o conteúdo da filosofia como puramente lingüístico. Nossa hipótese, por outro lado, não é absolutamente solidária de uma conjetura logicista relativa à natureza dos sistemas de conceitos que constituem uma filosofia. (GRANGER, 1989, p.165).

É difícil defender a idéia de metaconceito sem conduzi-la a um domínio positivo que atribui a apenas uma ciência a crítica de todas as outras. Se a filosofia é tal "ciência" acaba por se condenar a um universo totalmente separado do vivido, não se definindo pela abstração de suas experiências nem pela descrição direta de seus fatos. Granger (1989, p.165) é claro ao afirmar que a filosofia não deixará de existir por uma operação positiva, que é sempre incompleta e, também, a ciência não será reduzida ao positivismo que a persegue ao longo da história, mas que nunca terá seu processo terminado. Pode-se afirmar assim que, para Granger, a posição totalizante de uma ciência ou de uma filosofia positivistas, em sentido estrito, não seria possível mesmo com o uso de uma linguagem baseada estritamente na lógica. Mesmo que se queira, não é possível estabelecer, por meio de proposições claras e verdadeiras, relação direta com os fatos da realidade; também não é possível explicar e controlar todos os fenômenos aos quais a natureza é submetida. Toda pretensão de controle e universalidade é, por si só, simplista.

Mas a noção de metaconceito pode ser descrita de maneira mais objetiva. Nas palavras de Granger (1989, p.167) se “[...] o vivido não se dá ao filósofo enquanto exige uma construção de objetos, é porque se dá, então, como expressão e representação, o que exige uma interpretação do que o vivido significa. É nisto que o conceito filosófico 
é metaconceito". O autor reitera, ainda, a oposição entre conceitos exatos e "inexatos" como fundamental para se compreender como ocorre a abstração na própria filosofia. Dois pontos de vista são indicados neste caso: um positivo e outro negativo.

Do ponto de vista positivo, Granger (1989, p.173. Grifos do autor) procura dizer o que é o conceito filosófico e qual a sua relação com o vivido. O conceito filosófico, então, seria o "[...] correlato abstrato de um vivido, a palavra abstrato designando aqui simplesmente o que não é vivido isoladamente enquanto tal". Ao contrário da ciência, a filosofia retira quase todos os seus conceitos da correlação com o vivido, mesmo que suas noções sejam abstratas ou formais, ou seja, “[...] por mais afastada da experiência que uma noção filosófica nos pareça, por mais 'abstrata', por mais 'formal' que ela seja, ela seria apenas uma noção auxiliar importada, se não se referisse a um vivido”.

Não há relação direta da filosofia com as coisas (objetos) do vivido e muito menos um esquadrinhamento no sentido de decompô-lo em partes (recortes) como ocorre com a ciência. Ao contrário, a noção de correlação com o vivido e de abstração filosófica indica uma relação mediada e não imediata. A mediação deste processo, que podemos chamar de construção de símbolos e de expressão de significados, ocorre na linguagem. O princípio chamado de correlato abstrato do vivido é justamente a intenção de fazer com que os sistemas simbólicos, mediados pela linguagem, sejam considerados como o próprio vivido. Dessa maneira, há a passagem da idéia de imediato para o mediato na apreensão dos sentidos do vivido.

Não se trata, portanto, de colocar o conceito filosófico no âmbito de classes de equivalência, pois, a filosofia não tem uma perspectiva estritamente classificatória.

O conceito filosófico, como todo conceito, é pois construído como nó de relações, e não apreendido como intuição pontual. Ao menos o trabalho filosófico de conceitualização consiste em substituir as apreensões imediatas de um vivido complexo e extratificado, por hierarquias de relações. Mas estas 'relações' não são redutíveis a esquemas de conjunto, tais como os que são operados quase pela definição russerliana de relação como classe de pares, quer a partir da noção de morfismo e de categoria. Não bastaria, de resto, dizer que as noções em causa estão em 'intensão', opondo-as às relações extensivas; porque as primeiras, no campo do conceito científico, são sempre implicitamente reputadas de redutíveis às segundas, por meio da introdução de novos conceitos mais articulados, isto é, pela construção de um feixe mais fino de classe de equivalência. Digamos provisoriamente que as 'relações' constitutivas de conceitos filosóficos repousam numa relação fundamental, sui generis de sentido, não de conjunto. Na ciência, a oposição entre o extensivo e o intensivo permanece provisória, na realidade; e, neste ponto, pode-se subscrever as teses neopositivistas que postulam a redutibilidade extensiva de todos os conceitos, na medida em que são 
cientificamente cognoscíveis. A diferença entre conceitos efetivamente reduzidos a estruturas extensivas e conceitos intensivos só provém então do grau de acentuação, colocado - provisoriamente - mais sobre o sistema de objetos que sobre o sistema operatório. E se tal relação introduz-se primeiro como intensiva e designando uma irredutível constatação da experiência, o progresso de elaboração científica consiste sempre em explicar o corpo de operações, matemáticas e empíricas, que lhe dá seu verdadeiro estatuto de correlato operatório. Não se dá, seguramente, o mesmo com noções filosóficas, no sentido de que a análise bem pode introduzir indefiníveis determinados, ao mesmo tempo como representantes - como Vertreter - do vivido e como functores simbólicos numa linguagem; mas não representam nunca o simples papel de elementos numa combinatória (GRANGER, 1989, p.174).

Não se nega a característica relacional do conceito filosófico, mas é preciso notar que seu escopo é mais abrangente que o do conceito científico porque este requer operação empírica. Os conceitos filosóficos não podem ser organizados por categorias ou classificações sem que antes se estabeleça uma relação fundamental de sentido entre eles. Não é possível categorizar e organizar conceitos filosóficos em sistemas operatórios. Por outro lado, a hipótese de não redução do conceito filosófico a um universo operatório (apesar de indicado na citação acima), por meio de categorização e classificação, fundamentada-se em princípios filosóficos. De certa forma, é diante da maneira como os conceitos surgem e são construídos que sua organização será definida, ou seja, se os conceitos filosóficos não são empíricos, não têm relação direta com o vivido e suas relações são de abstração, sua organização também deve ser feita por abstração, procurando elementos de sentido e não características de conjunto.

O princípio operacional é próprio da ciência. Os conceitos científicos funcionam em um sistema de relações que podem ser operacionalizados e, até certo ponto, dependem disso para sobreviverem. A noção de categorias e classificação acaba por introduzir o princípio de unidade da ciência. Na filosofia, nem uma coisa nem outra é possível para Granger (1989). Mas, o autor lembra que a filosofia não está imune a alguns pontos críticos sobre seus próprios conceitos, pois alguns deles podem ser rigidamente definidos e conduzidos a "funções operatórias unívocas". Granger (1989, p.175) coloca de forma interrogativa esta questão e identifica como "frouxos" os conceitos que nela poderiam estar contextualizados. Como exemplos de conceitos filosóficos "frouxos" estariam o de "acidente", de Aristóteles, e o de "atributo", de Spinoza.

Mas tais conceitos "frouxos" teriam um lado "positivo". Para caracterizá-los, Granger (1989, p.178) indica que a inexatidão dos conceitos morfológicos pode ser 
provisória e não necessariamente essencial. Citando Wittgenstein, o autor usa uma metáfora para caracterizar sua idéia, dizendo que não se trata de separar o "duro do mole", mas de "mostrar o duro no mole".

Os conceitos empíricos são, do ponto de vista lógico, "fracos", mas quando integrados ao conhecimento científico, funcionam "[...] perfeitamente tal como no uso natural das palavras da linguagem." Neste processo, a axiomatização de um grupo de conceitos e traços "sincategoremáticos" estruturais fixados elimina qualquer tipo de "frouxidão" dos conceitos. Para Granger (1989, p.180) a idéia de fixação dos conceitos e eliminação da "frouxidão" dos conceitos é tentadora para a filosofia, mas carrega em si uma ilusão.

A ilusão da redução dos conceitos filosóficos a conceitos exatos, à qual se refere Granger, esclarece sua argumentação sobre o conceito filosófico, pois, é “[...] na medida em que tal redução permanece imperfeita que um conceito pode ser considerado sob $o$ ângulo filosófico, e filosofar consistiria então em mostrar como e até que ponto se manifesta esta irredutibilidade" (GRANGER, 1989, p. 180-181). Ao contrário do que ocorre no conhecimento científico, os conceitos originários não seriam destituídos de sua "frouxidão", mas seriam observados e teriam suas "marcas" identificadas para vêlas "[...] funcionar como obstáculo e como ponto de apoio". Ainda, segundo o autor, não é “[...] sobre o caráter 'vago' dos conceitos filosóficos que é preciso insistir tanto, porque esta noção só assume seu verdadeiro sentido relativamente a uma perspectiva de matematização mais ou menos intensa, cujo estilo já nos aparece como estranho ao filósofo." (GRANGER, 1989, p.181).

Até o momento, os argumentos de Granger passaram pela lógica, pela matemática, pela ciência e fenomenologia. Agora, seguindo a noção metafórica de "mostrar o duro no mole”, Granger (1989, p.182) nos coloca diante da concepção das "semelhanças de família", de Wittgenstein, que permite esclarecer sua abordagem sobre o conceito filosófico.

Falar de 'semelhanças de família' é, na verdade, usar metáforas e logo denunciaremos os perigos da metáfora para todo pensamento que se pretende rigoroso. Mas esta metáfora, como todas as que Wittgenstein usa, introduz a forma de um ato de pensamento e não a forma de uma coisa. Atrai nossa atenção sobre a impossibilidade de construir certos conceitos como constelação de caracteres. Entre os membros de uma mesma família, alguns terão um tipo de nariz mas não de queixo; outros a fronte, mas não o nariz... Dito de outro modo, não é possível remeter, neste caso, o conceito à intersecção comum das classes de traços que descrevem aparentemente seus 
representantes. Daí resulta naturalmente uma 'inexatidão', uma fluidez da noção, cujos contornos não podem ser esboçados antecipadamente por meio de operações booleanas. Mas este caráter vago não é, como os conceitos morfológicos husserlianos, a consequiência imediata de uma análise insuficiente. (GRANGER, 1989, p.183).

A aproximação com as "semelhanças de família" wittgensteiniana permite afirmar que Granger defende que a análise filosófica é análise de conceitos em linguagem natural. Isso explica sua insistência em dizer que o seu principal objetivo é analisar a relação existente entre os conceitos filosóficos com o vivido. Parece evidente a complexidade e, ao mesmo tempo, a "inexatidão" que os conceitos retirados das experiências do vivido comportam. Dessa forma, segundo Granger (1989, p.185-186. Grifos do autor),

A formação do conceito filosófico consiste numa tentativa de organizar esta não-pertinência originária e tornar explícita uma supercodificação que só se manifesta, além da gramática constitutiva da língua, em homologias de fundamento tácitas e lábeis. Neste sentido, a formação dos conceitos filosóficos é assunto de estilo e não de descoberta de essências; neste sentido, as palavras do filósofo não remetem nem a coisas nem propriamente a atos. Visam, antes, explicar organizações 'inexatas', porque não objetivantes, de conceitos, organizações que são apresentadas como vivências e não como teorias. Daí resulta que não é absolutamente concebível um discurso filosófico inteiramente purgado de todo conceito natural mas que, ao contrário, o conceito filosófico é freqüentemente produzido a partir de tais conceitos, que ele visa pôr em perspectiva e aos quais impõe uma sobredeterminação que é um estilo. Donde o uso do qualificativo 'refletido', que acreditamos poder empregar e a constatação da impropriedade radical de uma Mathesis universalis.

A preocupação de Granger quanto ao princípio de não-universalização dos conceitos filosóficos, no sentido de não se tomar o conceito filosófico como exato e isolado, reitera a noção de distanciamento dos conceitos filosóficos dos objetos da realidade; por outro lado, os aproxima dos sistemas simbólicos, cujos significados são expressos pela linguagem. Nesse sentido, o autor se pergunta qual seria a relação da filosofia com a linguagem, evidenciando de imediato que não é a mesma relação estabelecida entre a ciência e a linguagem.

Ao contrário da ciência, a filosofia não trabalha com conceitos reduzidos a conjuntos esquemáticos:

O desejo de reconduzir a linguagem filosófica a um certo número finito de sinais de emprego fixo, e do qual suporíamos os sentidos realmente definidos, foi certamente a tentação de muitos filósofos, dos quais um historiador erudito poderia se comprazer em exumar ensaios desde a Idade Média (GRANGER, 1989, p.188) 
Para o autor é uma ilusão tentar criar uma "verdadeira língua formal" em filosofia. As consequiências de tal tentativa resultam em formas extremadas de reação, chamadas de "[...] tentação do indizível e redução da filosofia a uma crítica da linguagem" (GRANGER, 1989, p.199. Grifos do autor). Mas, o sentido regulador imposto aos conceitos filosóficos não limitariam efetivamente os próprios conceitos filosóficos. A metáfora de que o horizonte não é o limite da caminhada para o viajante, utilizada por Granger (1989, p.200), exemplifica os limites da linguagem e introduz uma questão diretamente relacionada a ela: o indizível de Wittgenstein ${ }^{36}$.

O indizível pressupõe, segundo Granger (1989, p.200-203), muitas abordagens e formas de análise: a noção incorporada pela lógica de uma linguagem formal e correta para a "ciência"; o processo de elucidar modos de expressão simbólicos e mostrar seus limites e a posição que toma a filosofia como crítica da linguagem. Apenas a segunda forma de abordagem estaria de acordo com a idéia dos limites da linguagem (ou o indizível) de Wittgenstein. Não se trata de buscar uma linguagem correta, mas de entender as armadilhas da linguagem.

Nesse caso, temos uma noção das críticas, aqui de Granger, e anteriormente de Deleuze e Guattari (2004), à lógica, à fenomenologia e à própria metafísica com relação aos conceitos e à linguagem. Para entender melhor tais críticas, é importante retomá-las

Granger (1989, p.200) afirma que, na perspectiva da lógica, a tese da filosofia como crítica da linguagem

Pode ser, em primeiro lugar, o projeto para estabelecer uma linguagem formal correta para a ciência. Reconhecemos então a tarefa do Carnap da Sintaxe lógica. A filosofia é, como conseqüência, identificada a uma explicação da sintaxe - mais tarde da semântica - da linguagem objetiva. Ela, desde então, não atende à sua vocação legítima, se favorece ao contrário a confusão de enunciados da linguagem objetiva e enunciados que têm por objeto essa mesma linguagem. Os conceitos filosóficos autênticos são, pois, nesse caso, os meta-conceitos de uma gramática das ciências, que não seria outra, num sentido mais amplo, que a lógica. Seria restringir aí, de modo provavelmente roborativo em seu tempo, mas verdadeiramente draconiano, o campo da filosofia, e lançar às trevas do pseudoconceito a maior parte das noções elaboradas por aqueles que costumamos pôr na mesma classe dos grandes filósofos.

Ainda sobre a tese, porém relacionada à metafísica, Granger $(1989$, p.203) afirma que

A última interpretação de uma filosofia como crítica da linguagem constitui, nos parece, uma total desnaturação que propomos denunciar. Ela consiste em

\footnotetext{
${ }^{36}$ Especificamente sobre a experiência do indizível de Wittgenstein, ver Faustino (2006).
} 
considerar a linguagem como depositária de uma metafísica profunda e dissimulada que caberia ao filósofo atualizar. É a etimologia ousada ou fantasista, que servirá de fio condutor para a exploração desse labirinto. Nosso Aladin, em seu tempo, praticou este método com muito engenho e brio, e num estilo cavalheiresco do qual podemos realmente experimentar a desenvoltura, se quisermos. Mais próximo de nós, Martin Heidegger emprega muito freqüentemente os recursos de seu gênio, que só produzem então mitos ali onde esperávamos conceitos.

Em Deleuze e Guattari encontra-se um comentário sobre a posição de Granger a respeito do conceito na lógica e na ciência.

Embora seja perigoso para a filosofia depender da generosidade dos lógicos, ou de seus remorsos, podemos perguntar se não podemos encontrar um equilíbrio precário entre conceitos científico-lógicos e os conceitos fenomenológico-filosóficos. Gilles-Gaston Granger pôde propor uma repartição em que o conceito, sendo de início determinado como função científica e lógica, deixa todavia um lugar de terceira zona, mas autônomo, a funções filosóficas, funções ou significações do vivido, como totalidade virtual (os conceitos confusos parecem desempenhar um papel de eixo articulador entre as duas formas de conceitos). A ciência rogou o conceito a si mesma, mas há também conceitos não-científicos, que suportamos em doses homeopáticas, isto é, fenomenológicas. Donde os mais estranhos híbridos que se vê nascer hoje, do frege-husserlianismo ou mesmo de wittgenstein-heideggerianismo. Não era já, há muito tempo, a situação da filosofia na América, com um grande departamento de lógica e um minúsculo de fenomenologia, embora os dois partidos estivessem sempre em guerra? É como patê de cotovia, mas a parte da cotovia fenomenológica nem sequer é a mais refinada, é a que o cavalo lógico concede, às vezes, à filosofia. É antes como o rinoceronte e o pássaro que vive de seus parasitas (DELEUZE; GUATTARI, 2004, p.186-187).

Os trechos acima permitem evidenciar alguns pontos discordantes sobre o formalismo da linguagem e, por extensão, sobre os próprios conceitos.

Diante das perspectivas analisadas em Granger (1989), pode-se observar que o conceito filosófico não desqualifica as abordagens lingüísticas, lógicas e científicas, mas também não as considera sem problemas. Por exemplo, a idéia de formalismo da linguagem na lógica e a noção de referente e significado na lingüística seriam obstáculos à produção e, principalmente, à própria compreensão dos conceitos, como foi visto tanto em Granger como em Deleuze e Guattari.

2.8 Natureza dos conceitos nas ciências cognitivas: Eleanor Rosch e Vygotsky

As Ciências Cognitivas surgiram nos Estados Unidos há pelo menos quatro décadas. Dentre suas vertentes interdisciplinares, como a psicologia cognitiva, a computação (modelagem e inteligência artificial), a epistemologia e filosofia da mente, a neurociência, a linguística e a antropologia, encontra-se o estudo dos conceitos. Estamos nos referindo à vertente de estudos do conceito especificamente, pois, 
enquanto área de estudos, as Ciências Cognitivas vêm se desenvolvendo, não necessariamente com esse nome, desde a Grécia antiga. (GARDNER, 2003). As origens dos estudos sobre os conceitos nessa área estão fundamentadas, segundo Oliveira e Oliveira (1999, p.ix), nos trabalhos desenvolvidos na década de 1970 pela psicóloga e antropóloga norte-americana Eleanor Rosch.

\section{A Tradição Roschiana}

De acordo com a tradição roschiana, as etapas das investigações sobre o conceito, ao longo da história, segundo Oliveira (1999, p.17), estão divididas em três períodos:

Primeiro período: concepção clássica, que vai de Aristóteles até o início da década de 1970 ;

Dois pontos podem ser destacados na tradição clássica: precisão e propriedades individualmente necessárias. A tradição clássica é caracterizada pela natureza binária e a precisão conceituais. Os conceitos são do tipo "tudo-ou-nada", ou seja, um conceito aplica-se ou não a uma entidade, “[...] não há casos limítrofes e se duas entidades quaisquer são exemplares de um conceito, elas o são a igual título, ou seja, um conceito não se aplica mais ou melhor a uma entidade que a qualquer outra." (OLIVEIRA, 1999, p.118). Não existe a hipótese, por exemplo, de alguém ser "ligeiramente", "medianamente" ou "extremamente" mortal. Ou a pessoa é mortal ou não. Se todas as pessoas são mortais não há ninguém mais mortal do que outro. Oliveira se refere a esta característica do conceito com o termo precisão; dessa forma, “[...] de acordo com a concepção clássica, pode-se dizer, os conceitos são absolutamente precisos."

A segunda característica da concepção clássica é a que diz que os conceitos são um conjunto de atributos, no caso, as propriedades (necessárias e suficientes). De acordo com Oliveira (1999, p.118-119), isso quer dizer que “[...] para cair sob um conceito, uma entidade deve possuir cada uma das propriedades que o constituem, e que a posse de todas essas propriedades é suficiente para que a entidade seja um exemplar do conceito". Se considerarmos que animal e racional são propriedades do conceito homem, uma entidade somente será um homem se for animal e racional e vice-versa: a entidade que é animal e racional é um homem. A "lista", o conjunto de propriedades necessárias e suficientes, forma a definição de um conceito.

A concepção aristotélica sobre a natureza dos conceitos, especialmente da lógica aristotélica, foi predominante por quase toda a história da filosofia. A concepção 
clássica tem na lógica aristotélica, segundo Oliveira (1999, p.119), seu pressuposto fundamental $^{37}$. A concepção clássica aparece como "terreno comum" nas discussões de diferentes áreas.

Segundo período: concepção prototípica (probabilistica), que vai de 1970 até 1985;

Eleanor Rosch foi influenciada por Wittgenstein, considerado o precursor da "revolução roschiana" "38; também partiu deste último o questionamento sobre a tradição clássica. Segundo Oliveira (1999, p.121),

O primeiro questionamento da concepção clássica encontra-se no trabalho do segundo Wittgenstein. Na nota 66 das Investigações filosóficas, ele expõe um argumento que se tornou famoso, em que o leitor é desafiado a indicar uma característica comum a todos os jogos. Se tal característica não existe, então, é claro, o conceito de jogo não pode ser definido por um conjunto de propriedades necessárias e suficientes. Esta discussão prepara o terreno para a introdução, na nota seguinte, da noção de semelhanças de família. Em outras notas a seguir, Wittgenstein também trata do tópico da precisão, argumentando contra Frege, que conceitos não necessitam ser precisos para serem úteis.

Na concepção clássica, o conceito apresenta natureza binária, se aplicando ou não a uma entidade; na concepção prototípica, o conceito aplica-se a uma entidade "[...] em um certo grau, havendo casos mais, e menos típicos. Para cada conceito, o pico de tipicidade corresponde ao que Rosch denominou o protótipo do conceito - como uma generalização da idéia de 'cor focal'." (OLIVEIRA, 1999, p.123).

A concepção prototípica, diferentemente da clássica, atribui aos conceitos uma natureza contínua, gradual. Para cada conceito, existem representantes mais, ou menos típicos, e não é nítida a linha que separa os exemplares dos não-exemplares de um conceito; sempre podem existir casos limítrofes. Como a concepção clássica, a prototípica identifica conceitos com conjuntos de propriedades; nesta, entretanto, as propriedades que constituem um protótipo, de tal maneira que a aplicabilidade de um conceito a uma entidade depende do grau de similaridade que existe entre a entidade e o protótipo do conceito. Em função deste grau, a entidade ou não será um exemplar do conceito, ou será um caso limítrofe, ou será um exemplar - menos, ou mais típico. (OLIVEIRA, 1999, p.123).

A discussão acima evidencia a questão que está entre o conceito e o exemplar do conceito, por exemplo, o conceito de torre e uma torre específica como a Torre Eiffel (OLIVEIRA, 1999, p.124). A partir de tais afirmações, uma série de experimentos

37 Oliveira (1999, p.143) retomará o argumento no capítulo "O naturalismo no estudo dos conceitos", afirmando que a conexão da concepção clássica com a lógica aristotélica realmente existe, porém, suas conexões são um pouco mais complexas devido às próprias concepções da lógica.

38 O termo "Roschian revolution" foi usado por Neisser (1987, p.vii) no prefácio da obra Concepts and conceptual development... por ele editada. 
foram realizadas no âmbito da Psicologia, por Eleanor Rosch, sobre os conceitos prototípicos $^{39}$.

Terceiro período: concepção teórica, de 1985 até os dias atuais.

A concepção teórica dos conceitos não os vê apenas como conjuntos de propriedades, como ocorre na concepção clássica e na concepção prototípica. Na concepção teórica, além das propriedades, as relações são importantes. As relações articulam e formam redes conceituais, que são vistas como teorias.

Por 'teorias' neste contexto deve-se entender não apenas teorias científicas, mas também estruturas cognitivas do senso comum. Por exemplo, com referência aos animais, qualquer ser humano normal, mesmo que não tenha recebido instrução formal alguma, sabe que os animais nascem, crescem e morrem, que os animais precisam se alimentar para se manterem vivos, que os animais procriam, pertencendo aos filhos à mesma espécie dos pais, e assim por diante. A este tipo de conhecimento costuma-se aplicar o termo 'ingênuo' ('naive'). As idéias relacionadas no exemplo acima constituiriam então uma zoologia ingênua, a qual, juntamente com a física ingênua, a química ingênua, a psicologia ingênua (esta mais conhecida como psicologia popular - folk psychology), etc., formariam o chamado senso comum. (OLIVEIRA, 1999, p.128).

Cada conceito é parte e elemento constitutivo da teoria na qual está inserido. É importante observar que a concepção teórica dos conceitos já era conhecida pela filosofia, principalmente pela filosofia da ciência. No campo da psicologia, porém, começou a receber maior atenção, no âmbito da tradição roschiana, a partir de 1985 (OLIVEIRA, 1999, p.129). O que é importante destacar é que a concepção teórica dos conceitos, segundo Oliveira (1999, p.132), “[...] constitui o último marco no desenvolvimento da tradição roschiana.”, embora as abordagens e as pesquisas dentro dessa tradição tenham tido continuidade. Na área da Organização da informação pode ser citado o trabalho de Iyer (1995), que discutiu a aplicabilidade da concepção prototípica aos processos documentários.

A noção de "conceito básico" também é atribuída a Eleanor Rosch. Antes de abordá-la, Oliveira (1999, p.126) frisa que os conceitos na concepção clássica e na concepção prototípica são estruturados dentro de domínios, em taxonomias. Para o autor, "O exemplo mais paradigmático de taxonomia é o sistema de classificação biológico, no qual cada organismo individual, ou seja, cada espécimen de ser vivo é

39 Muitos experimentos foram realizados sobre casos limítrofes e tipicidade dos conceitos. Não é nosso objetivo descrevê-los. Para aprofundamento do tema podem ser citados Oliveira e Oliveira (1999), Oliveira (1999), Smith e Medin (1981) e Neisser (1987). 
alocado a uma espécie, cada espécie a um gênero, cada gênero a uma família, e assim por diante." (OLIVEIRA, 1999, p.126).

O exemplo da classificação biológica é um exemplo de classificação científica, ou seja, de taxonomia científica, mas existem também taxonomias não-científicas. Estas últimas estão presentes na linguagem natural, no uso que se faz da linguagem no dia-adia, no universo do senso comum.

A taxonomia clássica, fundamentada na lógica aristotélica, apenas utiliza a hierarquia para distinguir os conceitos uns dos outros, ou seja, os conceitos mais gerais dos mais específicos, uniformizando os níveis taxonômicos. Eleanor Rosch introduz a idéia de que existem níveis especiais nas taxonomias que os distinguem, por meio de uma "série de particularidades cognitivas", dos outros níveis taxonômicos. Os níveis especiais são chamados de níveis básicos e seus respectivos conceitos, de conceitos básicos.

Além da noção de conceito básico, Eleanor Rosch introduziu as noções de conceitos subordinados e superordenados. "A idéia é bem simples. Por exemplo, se 'carro' é um conceito básico, 'veículo' é um conceito superordenado, e 'carro esporte' um conceito subordinado." (OLIVEIRA, 1999, p.127). Deve-ser observar que no âmbito da Organização da informação e do conhecimento, superordenação e subordinação são conceitos que remetem mais às teorias linguísticas do que à tradição roschiana.

Mas, como o enfoque principal de Rosch pertence ao campo da cognição, as características cognitivas que podem ser relacionadas aos conceitos básicos, de acordo com Oliveira (1999, p.127), são:

- Os conceitos básicos são “[...] apreendidos pelas crianças: 'gato', por exemplo, é um conceito básico, e é apreendido antes do conceito superordenado 'animal', e antes do subordinado 'gato siamês'".

- Os conceitos básicos são “[...] mais rapidamente aplicados, ou seja, o tempo médio, medido em experimentos psicológicos, que uma pessoa leva para identificar um objeto como um martelo (outro conceito básico) é menor que o tempo gasto para identificá-lo como uma ferramenta, ou como um martelo de vidraceiro."

- Os conceitos básicos "Correspondem ao nível mais alto para o qual uma única imagem mental é associada ao conceito como um todo." 
- Os conceitos básicos "Correspondem ao nível mais alto em que uma pessoa usa programas motores semelhantes para interagir com as entidades às quais o conceito se aplica."

É importante destacar que a concepção de conceitos no nível básico realça a nãouniformidade dos níveis taxonômicos, como demonstrado no exemplo de "gato" e de “martelo" acima. Para Oliveira (1999, p.127), este princípio está totalmente ausente da lógica aristotélica.

\section{O naturalismo no estudo dos conceitos}

Oliveira (1999) também tece críticas à tradição roschiana. Baseando-se na distinção entre as visões das ciências humanas e das ciências naturais sobre seus objetos de estudo, o autor afirma que as primeiras encerram alto grau de normatividade, não ocorrendo o mesmo com as ciências naturais. Porém, "Os pesquisadores da tradição roschiana, em contraste, simplesmente ignoram a dimensão normativa presente no estudo dos conceitos" (OLIVEIRA, 1999, p.137. Grifos do autor). Ou seja, é necessário que se sigam regras ou normas para falar ou comportar, mas não faz sentido que um objeto externo (uma pedra, uma cadeira) o faça.

Além de ignorar a dimensão normativa, os cognitivistas também não levam em consideração o desenvolvimento histórico dos conceitos.

No que se refere às capacidades cognitivas, é possível distinguir pelo menos dois níveis de desenvolvimento: o ontogenético, ou seja, o desenvolvimento cognitivo de cada indivíduo ao longo de sua vida (e especialmente na infância), e o filogenético (usando o termo num sentido que inclui não apenas a evolução biológica das espécies, mas também a história propriamente dita da humanidade). Pois bem, pelo menos em relação aos conceitos, podemos dizer que os cognitivistas reconhecem, e estudam seu desenvolvimento ontogenético, porém ignoram quase totalmente seu desenvolvimento histórico.

Com referência à história, diremos então que a tradição roschiana tem uma visão estática dos conceitos. Seu objetivo é estudar uma natureza suposta imutável dos conceitos (e este é seu erro fundamental). (OLIVEIRA, 1999, p.138).

O que se pretende destacar é a observação de Oliveira (1999, p.153) de que assim como na tradição roschiana, a crítica de Wittgenstein à concepção clássica dos conceitos também está associada a uma visão estática dos conceitos. 
A hipótese de Oliveira parte da análise da idéia de precisão e definibilidade dos conceitos e do exame crítico do parágrafo 66 (na íntegra, adiante) sobre os "jogos" da obra Investigações filosóficas de Wittgenstein ${ }^{40}$.

Oliveira justifica o interesse pelo argumento (parágrafo 66) por sua influência nos estudos de Eleanor Rosch. Para Oliveira (1999, p.151) a pesquisadora desenvolve sua concepção sobre os conceitos, a concepção probabilística ou prototípica, inspirada, dentre outros aspectos, no parágrafo 66 de Wittgenstein.

A concepção prototípica contrasta com a concepção clássica dos conceitos. Esta última permanece na filosofia e na lógica, desde Aristóteles, com grande influência em muitas outras áreas que se interessam pelos estudos sobre o conceito. Na concepção clássica, os conceitos são identificados com um conjunto de propriedades necessárias e suficientes. A listagem, a enumeração das propriedades necessárias e suficientes constitui a definição de um conceito, atribuindo-lhe uma "[...] natureza precisa, do tipo tudo-ou-nada: ou bem um conceito aplica-se a uma entidade, ou bem não se aplica, não existe meio termo, nem exemplares mais ou menos típicos." (OLIVEIRA, 1999, p.152). Na concepção prototípica, os conceitos também são identificados como conjuntos de propriedades, porém, nenhuma das propriedades é individualmente necessária. O conjunto de propriedades seria um protótipo e não um conjunto necessário. A aplicação de um conceito a uma entidade dependerá do grau de semelhança desta entidade com o protótipo do conceito, isto é, dependerá da quantidade de propriedades compartilhadas entre ambos. O grau de semelhança (o número de propriedades compartilhadas) determinará se a entidade será um conceito, um conceito mais ou menos típico.

Segundo Oliveira (1999) o mérito da tradição roschiana foi ter "categorizado" a tradição clássica. Por outro lado, a crítica à tradição roschiana reside justamente na sua pretensão de querer substituir a tradição clássica, considerando-se como a "[...] concepção que representa a verdadeira natureza dos conceitos." Ainda de acordo com o autor, a “[...] tese central da tradição roschiana é, portanto, a de que os conceitos de maneira geral - e especialmente os do senso comum, que constitui seu domínio preferencial de investigação - correspondem à concepção prototípica, e não à concepção clássica”. (OLIVEIRA, 1999, p.152).

\footnotetext{
${ }^{40}$ Oliveira (1999, p.151) lembra que o parágrafo 66 de Wittgenstein (2005) é referenciado e analisado em diversos e importantes textos e cita, como exemplo, A estrutura das revoluções científicas de Kuhn (2001). O parágrafo 66 serve como base para a introdução da conhecida noção de semelhanças de família de Wittgenstein (2005, p.51-52, §66 e §67).
} 
Essa tese é equivocada, segundo o autor, devido a um exagero atribuído ao grau de correspondência entre a concepção prototípica e os conceitos. A tradição roschiana coloca todos os conceitos dentro da concepção prototípica, pois, os considera estáticos. A visão estática desconsidera o desenvolvimento histórico dos próprios conceitos. Em contrapartida, Oliveira (1999, p.152) propõe que os conceitos sejam vistos de uma forma "[...] dinâmica, ou dialética, que não apenas leva na devida conta a evolução dos conceitos, mas também procura determinar suas causas, procura estabelecer as forças motrizes de seu desenvolvimento."

Oliveira (1999) propõe analisar um dos exemplos usados pela tradição roschiana na crítica à concepção clássica. Nas palavras do autor:

No que se refere à definibilidade dos conceitos, as objeções da tradição roschiana à concepção clássica apóiam-se na análise de um certo número de casos particulares, ou seja, em relação a um dado conceito, examinam-se várias tentativas de formular uma definição para ele, procurando mostrar serem todas elas insatisfatórias. Estas análises são, em nossa crítica, submetidas a um reexame. Entre elas, a mais importante, devido a seu papel de precursora, é a do argumento wittgensteiniano relativo ao conceito de jogo. (OLIVEIRA, 1999, p.152-153).

Para demonstrar que o argumento de Wittgenstein quanto à visão estática dos conceitos também não procede ${ }^{41}$, Oliveira $(1999$, p.153) propõe o desenvolvimento de dois "lemas". Na concepção clássica, como anteriormente observado, um conceito se aplica ou não a uma entidade, não existindo, portanto, casos mais ou menos típicos. Oliveira (1999, p.153) chama esta característica de precisão. Uma segunda característica da concepção clássica seria a definibilidade, que se traduz pela possibilidade de um conceito ser definido por um determinado conjunto de propriedades necessárias e suficientes. Essas duas características também fundamentam a concepção prototípica, sendo adotadas em níveis absolutos e não em níveis de gradação, o que seria um equívoco por três motivos: a) “[...] a precisão de um conceito é uma questão de grau [...]"; b) "[...] na imprecisão de um conceito deve-se distinguir duas componentes, que denominaremos vagueza e indeterminação, e apenas a indeterminação implica a indefinibilidade [...]”; e c) “[...] a definibilidade de um conceito é também uma questão de grau." (OLIVEIRA, 1999, p.153). Portanto, em vez de estabelecer uma norma absoluta, seria mais adequado aceitar definições também por gradação. Os "lemas", propostos por Oliveira (1999, p.155-156. Grifos do autor) são:

41 Oliveira (1999, p.153) destaca que em vários autores e comentadores de Wittgenstein, inclusive em Eleanor Rosch, o conceito de jogo aparece quase sem nenhuma crítica, ou sem nenhuma crítica. 
Lema 1: "A vagueza de um conceito não implica a sua indefinibilidade."

Lema 2: "A indefinibilidade de um conceito é uma questão de grau."

Para fundamentar o primeiro lema, Oliveira parte de um argumento de Fodor, no qual analisa a definição do conceito de pintar:

A primeira consideração é que o motivo pelo qual a definição não funciona nada tem a ver com uma suposta ou real vagueza do verbo 'pintar', embora esta seja uma pista falsa que freqüentemente se encontre por aqui [a red herring that often swims about here]. Por exemplo, alguém pode dizer que 'x cobre a parede com tinta' não é necessário para 'x pinta a parede' uma vez que, com certeza, pode-se ter pintado a parede mesmo havendo um pedacinho lá em cima, no canto superior esquerdo, que tenha sobrado, e portanto, não tenha sido coberto com tinta. Neste caso, pode ser que a parede tenha sido pintada descuidadamente, ou imperfeitamente; porém não obstante ela foi pintada.

Porém o (suposto) fato de que o verbo 'pintar' é vago não é a razão para acreditar que ele seja indefinível; a implicação é apenas que qualquer expressão que defina 'pintar' precisa também ser vaga, e da maneira correta. Na verdade, a definição em termos de 'cobrir' dá bem conta do recado, pois, se é possível dizer que a parede foi pintada embora tenha sobrado um pedacinho, é possível também dizer que a parede foi coberta com tinta embora tenha sobrado um pedacinho. A vagueza do definiens e a do definiendum, por assim dizer, se harmonizam; e na medida em que isto acontece, a vagueza não é argumento contra a definibilidade. (FODOR ${ }^{42}$, 1991, p.285-286 apud OLIVEIRA, 1999, p.155)

As definiçõos satisfatórias, portanto, não são necessariamente compostas pelo conjunto de todas as propriedades constituintes e necessárias de um conceito.

O segundo lema prevê que a definibilidade de um conceito é "uma questão de grau". No exemplo de Oliveira (1999, p.156) um conceito pode ter uma definição insatisfatória por ser muito ampla ou por ser muito restrita. A exclusão ou inclusão de entidades indevidas na definição de um conceito é chamada pelo autor de "casos desfavoráveis”. Quanto menor for o número de casos desfavoráveis na definição de um conceito, mais satisfatória ela será e melhor será a sua definição.

É importante que se inclua o parágrafo 66 sobre os "jogos" da obra "Investigações Filosóficas" de Wittgenstein para entender melhor a posição de Oliveira (1999):

Considere, por exemplo, os procedimentos que chamamos de 'jogos'. Refirome a jogos de tabuleiro, jogos de cartas, jogos de bola, jogos olímpicos, etc. O que é comum a todos eles? - Não diga: 'algo deve ser comum a todos eles, senão não se chamariam 'jogos" - mas olhe se há algo comum a todos eles. Pois, se você os contempla, não verá com efeito algo que seja comum a

\footnotetext{
${ }^{42}$ FODOR, J. A. "The present status of innateness controversy". In: Representations: philosophical essays on the foundations of cognitive science. Cambridge (EUA), The MIT Press, 1991. Reproduzido a partir da bibliografia de Oliveira (1999).
} 
todos, mas verá semelhanças, afinidades, na verdade toda uma série delas. Como disse: não pense, mas olhe! - Olhe, por exemplo, os jogos de tabuleiro, com suas múltiplas afinidades. Agora passe para os jogos de cartas: aqui você encontra muitas correspondências com aqueles da primeira classe, mas muitos traços comuns desaparecem, e outros surgem. Se passarmos agora aos jogos de bola, muita coisa comum se conserva, mas muitas se perdem. - São todos 'recreativos'? Compare o xadrez com o jogo de amarelinha. Ou há em todos um ganhar e perder, ou competição entre os jogadores? Pense no jogo de paciência. Nos jogos de bola há um ganhar e perder; mas se uma criança atira a bola na parede e a apanha outra vez, este traço desapareceu. Olhe que papéis desempenham a habilidade e a sorte. E como é diferente a habilidade no xadrez e no tênis. Pense agora nos brinquedos de roda: o elemento de recreação está presente, mas quantos dos outros traços característicos desapareceram! E assim podemos percorrer muitos, muitos outros grupos de jogos e ver semelhanças surgirem e desaparecerem. (WITTGENSTEIN, 1979, §66 apud OLIVEIRA, 1999, p.157).

O primeiro lema está relacionado à criança que atira a bola na parede e a pega outra vez. A vagueza do traço "ganhar e perder", como distingue Wittgenstein, não implica a indefinibilidade do conceito jogo relacionado à ação realizada pela criança. $\mathrm{O}$ segundo lema fundamenta a crítica sobre a restrição de atributos proposta por Wittgenstein em sua definição de "jogos". Para Oliveira (1999, p.162), o que torna o conceito de jogos de Wittgenstein estático é a noção de que esse conceito tem uma “[...] estrutura de semelhanças de família, e ponto final."

\section{Vygotsky}

No final do capítulo "Wittgenstein, jogos e semelhanças de família", Oliveira (1999) faz uma analogia entre a concepção de semelhanças de família de Wittgenstein e o pensamento por complexos de Vygotsky (1991). Os estudos sobre a formação de conceitos, realizados por este último referem-se à formação dos conceitos na criança. Esses estudos foram realizados por Vygotsky e colaboradores do campo da psicologia, nas décadas de 1920 e 1930 (VAN DER VEER; VALSINER, 1999). As experiências desse grupo não se limitaram ao âmbito infantil (criança), mas à cadeia humana de processos cognitivos e da linguagem na formação e categorização de conceitos. De acordo com Oliveira (1992, p.27-28)

A linguagem humana, sistema simbólico fundamental na mediação entre sujeito e objeto de conhecimento, tem, para Vygotsky, duas funções básicas: a de intercâmbio social e de pensamento generalizante. Isto é, além de servir ao propósito de comunicação entre indivíduos, a linguagem simplifica e generaliza a experiência, ordenando as instâncias do mundo real em categorias conceituais cujo significado é compartilhado pelos usuários dessa linguagem. Ao utilizar a linguagem para nomear determinado objeto estamos, na verdade, classificando esse objeto numa categoria, numa classe 
de objetos que têm em comum certos atributos. A utilização da linguagem favorece, assim, processos de abstração e generalização. Os atributos relevantes têm de ser abstraídos da totalidade da experiência (para que um objeto seja denominado 'triângulo' ele deve ter três lados, independentemente de sua cor ou tamanho, por exemplo) e a presença de um mesmo conjunto de atributos relevantes permite a aplicação de um mesmo nome a objetos diversos (um pastor alemão e um pequinês são ambos cachorros, apesar de suas diferenças: os atributos que compartilham permitem que sejam classificados numa mesma categoria conceitual). As palavras, portanto, como signos mediadores na relação do homem com o mundo são, em si, generalizações: cada palavra refere-se a uma classe de objetos, consistindo num signo, numa forma de representação dessa categoria de objetos, desse conceito.

Os experimentos realizados por Vygotsky, nas primeiras décadas do século XX, consistiam, dentre outras coisas, em listar algumas características de um conceito e pedir a uma criança que o distinguisse de outros e o hierarquizasse. A dificuldade de trabalhar apenas com palavras levou ao desenvolvimento de um método de análise da formação de conceitos por meio do contato direto com objetos. Dessa maneira, enquanto “[...] o método da definição tenta compreender o processo de formação de conceitos em um plano puramente verbal, isolado dos objetos concretos a que os conceitos se referem, o método direto investiga a formação de conceitos na esfera puramente prática, isolando-a do papel orientador das palavras." (VAN DER VEER; VALSINER, 1999, p.284).

Superado o estágio de ordenação sincrética dos objetos (no qual a criança trabalha por tentativas de acerto e erro, ela seleciona objetos próximos e percebe grupos de objetos) (VAN DER VEER; VALSINER, 1999, p.288-289), passa para o estágio de formação de complexos (VYGOTSKY, 1991, p.52), em que procura características ou uma característica que seja compartilhada por diversos objetos ou por um conjunto de objetos.

O terceiro estágio, o da formação de conceitos “[...] propriamente ditos, a criança agrupa objetos com base num único atributo, sendo capaz de abstrair características isoladas da totalidade da experiência concreta." (OLIVEIRA, 1992, p.29).

Vygotsky (1991) demonstrou que o desenvolvimento conceitual das crianças por meio da formação de sincréticos e de complexos constituía “[...] apenas um aspecto de um todo complexo. Em sua opinião, a formação de todos sincréticos e de complexos baseava-se na combinação de objetos semelhantes em conjuntos." (VAN DER VEER; VALSINER, 1999, p.292). Além disso, Vygotsky entendeu que as crianças e os adultos usam as mesmas palavras para dizerem coisas diferentes, ou seja, há um universo 
semântico que se apresenta em níveis distintos para crianças e adultos, mesmo se eles estiverem se referindo aos mesmos objetos. Nesse caso, os experimentos artificiais que Vygotsky realizou são tomados como "esboços aproximados" (VAN DER VEER; VALSINER, 1999, p.294). São aproximados porque a formação de conceitos na criança tem seu desenvolvimento a partir da linguagem de seu grupo cultural. De acordo com Oliveira (1992, p.30) isso quer dizer que “[...] a trajetória de desenvolvimento de um conceito já está predeterminada pelo significado que a palavra que o designa tem na linguagem dos adultos."

Outros pontos das observações de Vygotsky sobre a formação de conceitos, como a própria noção de conceitos espontâneos (cotidianos e aprendidos na experiência prática do dia-a-dia) e conceitos não-espontâneos (científicos e aprendidos em universos formais de ensino, como a escola) (VAN DER VEER; VALSINER, 1999, p.295-304; OLIVEIRA, 1992, p.31) discutida a partir de Piaget (VYGOTSKY, 1991, p.71), estão entre os importantes estudos sobre a cognição desenvolvidos no século XX. 


\section{ORDEM DOS CONCEITOS NA ORGANIZAÇÃO DA INFORMAÇÃO E DO CONHECIMENTO}

\subsection{O que é um conceito?}

Tradicionalmente, a pergunta "O que é um conceito?" é realizada no início de quase todas as análises sobre o conceito. Os elementos, as características e as linhas de força teóricas que estão nas bases das respostas à pergunta "O que é um conceito?" refletem escolhas teórico-epistemológicas e, por extensão, permitem identificar os princípios adotados por autores da área da Organização da informação e do conhecimento. Então, o que é um conceito?

Dahlberg (1992 $2^{43}$ apud ALVARENGA, 2001, p.8) destaca algumas dificuldades para definir o termo conceito. Em sua origem grega, o conceito (horos) era composto por três elementos: logos, pragma e noema. Mas, em sua tradução para o latim, horos deu lugar a terminus que corresponderia apenas ao logos grego, ao seu aspecto linguístico. Dessa forma, segundo Dahlberg, muitos filósofos, ao longo da história utilizaram, terminus como conceito e também como elemento linguístico.

No século XVIII, essa questão foi resolvida por Christian Von Wolff (1679-1754), em tradução do próprio termo horos, mantendo conjuntamente suas características de signo (termo) e conteúdo (ALVARENGA, 2001, p.8). Esse re-encaminhamento etimológico aproxima-se das definições nucleares sobre o conceito utilizadas até os dias atuais.

No Dicionário Houaiss (HOUAISS; VILLAR, 2008, p.783-784) o conceito é definido como "produto da faculdade de conceber" que seria a "faculdade intelectiva e cognoscitiva do ser humano; mente, espírito, pensamento", por exemplo: "isso não entra no meu conceito". Além de faculdade da cognição, do conhecimento, o conceito também pode corresponder a noção, idéia, ponto de vista, opinião, avaliação, conclusão moral, reputação, etc. Esses elementos remetem a outros contextos de análise, como o filosófico e o da linguagem.

\footnotetext{
${ }^{43}$ DAHLBERG, Ingetraut. Knowledge organization and terminology; philosophical and linguistic bases. International classification, v.19, n.2, 1992, p.65.
} 
Em outra obra, o Dicionário do livro (FARIA; PERICÃO, 2008), a definição de conceito é mais próxima daquela utilizada na Organização da informação e do conhecimento. Um conceito pode ser:

Qualquer unidade de pensamento. Noção selecionada para reter como unidade de análise semântica, para fins de indexação. Na indexação os conceitos existentes num documento são extraídos pela análise, que os exprime através de palavras-chave. Elemento do pensamento expresso, em geral, por um termo ou por um símbolo literal ou outro. Noção. Preceito; máxima. (FARIA; PERICÃO, 2008, p.188).

Na sequência, Faria e Pericão (2008, p.188) descrevem mais sete tipos de conceitos: conceito colateral, definido como conceito associado; conceito composto, que se "[...] exprime através de várias palavras"; conceito específico, que é “[...] específico em relação a outro se este último for genérico do primeiro"; conceito genérico, "Um conceito é genérico em relação a outro se este último for definido pelos mesmos atributos que o primeiro com um ou vários atributos suplementares"; conceito geral especial, "Em classificação, subdivisão baseada numa característica que pode aplicar-se à subdivisão de uma classe geral e também às subdivisões dentro dela"; conceito isolado, é um conceito "[...] único que pode ser considerado separadamente para fins de definição ou para ser colocado num sistema de classificação"; conceito simples, é "Aquele que se exprime através de uma palavra”.

De acordo com Barité (2000, p.33), no Diccionario de organización y representación del conocimiento, em versão on line, o conceito é uma

Abstracción o noción que refiere a una unidad de conocimiento, independiente de su expresión lingüística, y comprende el conjunto de sus rasgos esenciales. El concepto, en tanto representación simbólica, está en la base de la Teoría de la Clasificación y de la Terminología, pues es el elemento indivisible que permite representar el conocimiento contenido en los documentos y organizar los enunciados correspondientes a la idea que se tiene de cualquier cosa. En vocabularios controlados y en lenguaje natural, el concepto se representa mediante un rótulo.

Verifica-se que a definição proposta por Faria e Pericão (2008), traz a idéia de conceito como "unidade de pensamento" e como "noção" aproximando-se da definição encontrada na norma ISO 1087. Barité (2000) também afirma que o conceito é uma noção, mas uma noção que se refere a uma unidade de conhecimento, como encontrado em Dahlberg.

O conceito é definido pelas normas ISO (International Organization for Standardization) como "[...] unidade de conhecimento criada pela combinação única de características" (unit of knowledge created by a unique combination of characteristics) 
(ISO 1087, 2000, p.2). A norma ISO 704 (2000, p.2) apresenta, inicialmente, os conceitos como "unidades de pensamento" (units of thought) e depois como unidade de conhecimento (unit of knowledge).

$\mathrm{O}$ Guidelines for the construction, format, and management of monolingual controlled vocabularies (ANSI/NISO Z39.19, 2005, p.4) define o conceito como

Uma unidade de pensamento, formada pela combinação mental de algumas ou todas as características de um objeto concreto ou abstrato, real ou imaginário. Conceitos existem na mente como entidades abstratas independente dos termos usados para expressa-los.

A definição de conceito como unidade de pensamento foi adotada, segundo Campos (2001, p.101), por Wüster e pela ISO/TC-37. Dahlberg (1978b, p.5), reformula essa concepção, afirmando que o termo "pensamento" pode ser subjetivo e impreciso, propondo definir o conceito como "unidade de conhecimento".

A questão é discutível, porém, subjetivo ou não, o conceito definido como unidade de conhecimento caminha para algo já externalizado, não restrito à mente daquele que pensa, pois, para se ter uma "totalidade de proposições verdadeiras sobre o mundo", como ocorre na ciência (DAHLBERG, 1978b, p.6), é necessário que tais proposições sejam expressas e comunicadas pela linguagem:

Tomando um universo de itens, selecionamos um como item de referência para nosso propósito, isto é, o 'referente'. Tais referentes podem ser um simples objeto, um conjunto de objetos considerados como uma unidade, ou uma propriedade, uma ação, uma dimensão, etc. ou qualquer destas combinações. Afirmações corretas sobre tal referente podem ser verificadas através de evidências ou de acordo intersubjetivo. Tais afirmações são então aceitas como verdadeiras numa forma verbal, que pode ser convenientemente usada, um termo ou um nome. Com tal forma verbal, somos então capazes de nos comunicar verbalmente e por escrito sobre os conteúdos (os julgamentos sobre o referente) de um conceito, inclusive aplicar um conceito nas nossas afirmações, no universo de nosso discurso. (DAHLBERG, 1978b, p.6).

O universo discursivo, delimitado pela forma de uso da linguagem em espaços específicos, é sedimentado em conceitos. Descrever as propriedades de um objeto ou construir um enunciado lógico e verdadeiro sobre uma "coisa do mundo" (HJORLAND, 2008) é a principal característica do conceito. A maneira como as coisas são vistas e representadas difere de cultura para cultura, como também de indivíduo para indivíduo. Dessa forma, a construção do conceito depende basicamente de um referente, da emissão de juízos sobre o referente, de uma forma verbal (um termo ou um nome) e de uma maneira de usar essa forma verbal em um universo discursivo. 


\subsection{O conceito na Classificação e na Terminologia}

$\mathrm{Na}$ Classificação, segundo Langridge (2006, p.21), o conceito é o principal elemento ("termo") dos estudos relacionados à classificação. Essa importância pode ser constatada em autores que já haviam analisado a teoria da classificação anteriormente, como Vickery $^{44}$ (1980, p.17. Grifos do autor) que diz que o seu principal objetivo é "[...] revelar satisfatoriamente as múltiplas inter-relações entre os conceitos da ciência." Vickery não diz "as relações entre a ciência", como podemos notar nas clássicas noções de classificações científicas em hierarquias e campos de referência, mas sim relações entre os conceitos da ciência ${ }^{45}$, ou seja, entre os conhecimentos (expressos em conceitos) produzidos pelas ciências. Nesse sentido, Langridge (2006, p.21) afirma que a primeira coisa a ser feita em relação aos conceitos é, justamente, distingui-los das palavras. Se os conceitos refletem os conteúdos, os conhecimentos das ciências, eles, evidentemente, se apresentam por meio de algum veículo (signo), a palavra. Porém, o conceito não se limita ao universo da palavra. Ele pode existir independentemente de uma palavra que o designe. Langridge (2006, p.21) diz, então, que "É possível também haver um conceito (de alguma coisa) para o qual não haja palavra para expressá-lo ou para o qual não conheçamos a palavra”. Por esse motivo é que Vickery (1980, p.23) já dizia que classificar é "reunir coisas ou idéias" e, portanto, segundo Richardson ${ }^{46}$ (1930 apud VICKERY, 1980, p.208. Grifos do autor) é possível afirmar que "'A ordem das ciências é a ordem das coisas."

Na classificação bibliográfica, além das tabelas de classificação tradicionais (Classificação Decimal de Dewey - CDD -, e a Classificação Decimal Universal CDU), há outros sistemas não estruturados numérica ou alfa-numericamente, como o tesauro $^{47}$ e as listas de assuntos. Na CDD, por exemplo a Lógica, que corresponde à notação (classe) 160, está contida na classe maior 100, Filosofia, pois tudo o que está dentro da classe 100 "pertence”, faz parte do domínio, da Filosofia. Em um tesauro, por outro lado, o princípio de classificação pode se basear na idéia de que a Lógica é a ciência da razão "correta" e a Filosofia é a área que comporta os estudos sobre a razão,

\footnotetext{
${ }^{44}$ O livro de Langridge (2006) teve sua primeira publicação na década de 1970 e de Vickery na década de 1950.

${ }^{45}$ Lembra-se da idéia proposta por Wittgenstein, logo no início deste trabalho, de que nosso interesse deveria estar voltado para os conceitos dos fenômenos e não para os fenômenos em si.

${ }^{46}$ RICHARDSON, E. C. Classification, theoretical an practical.3.ed. New York, 1930. Referência de Vickery (1980, p.223).

${ }^{47}$ Vickery (1980, p.159 e segs) enumera diversos tipos de tesauros.
} 
sobre o conhecimento, sem fazer dela seu objeto, distinguido-se conceitualmente de outras áreas, como a Física ou a Geografia, por exemplo.

A multidimensionalidade do conhecimento e as diversas maneiras pelas quais os conceitos se relacionam (VICKERY, 1980, p.216), exige constantes revisões das teorias e metodologias de organização da informação e do conhecimento.

Como visto em Langridge (2006), o conceito não é o mesmo que a palavra. Da mesma forma, o conceito, segundo Piedade (1983), deve ser distinguido do assunto. Os assuntos podem ser vistos como conjuntos de conceitos de determinada disciplina. Assim como Langridge, Piedade (1983, p.35) afirma que o conceito é a "[...] operação da inteligência através da qual se apreendem os caracteres essenciais daquilo que se conhece. É a representação mental do que se sabe, uma idéia, uma coisa, um julgamento etc." Dessa maneira, os conceitos podem ser

[...] expressos por palavras, sinais ou símbolos. O conceito 'cavalo', a idéia mental que temos de um cavalo, pode ser expresso pelas palavras cavalo, cheval ou horse, conforme a língua utilizada, bem como pelo símbolo de classificação 599.725, encontrado na Classificação Decimal de Dewey. (PIEDADE, 1983, p.35).

Como o signo linguiístico não precisa ser representado apenas por palavras ou termos (KRISTEVA, 1999, p.27; BENVENISTE, 2005, p.53), pode-se pensar o número 599.725 como representação de um signo linguístico, um conceito, que remete a um significante e tem um significado, como ocorre nos sistemas de classificação bibliográfica.

A Terminologia, de acordo com Barros (2004, p.28) "[...] é tão antiga quanto a linguagem humana", enquadrando-se como atividade exercida no campo dos conhecimentos especializados, desde tempos remotos (CABRÉ, 1999, p.72). Porém, como disciplina e como campo de estudo dos vocabulários técnico-científicos, seu desenvolvimento se dá mais sistematicamente a partir da segunda metade do século XX. (KRIEGER; FINATTO, 2004, p.25; BARROS, 2004, p.35). O estudo de termos, nomes, definições, frases e também de conceitos faz com que a Terminologia tenha, a exemplo da classificação, um amplo e consolidado horizonte de correlações e interfaces com outras áreas do conhecimento, especialmente com aquelas dedicadas aos estudos linguísticos, cognitivos, semânticos e lexicais. (KRIEGER; FINATTO, 2004, p.40; BARROS, 2004). 
A Terminologia se ocupa tanto dos modos de expressão dos conceitos (termos e símbolos, por exemplo) como do conteúdo semântico do conceito (BARROS, 2004, p.106). A análise conceitual na Terminologia procura determinar as características, a extensão, a compreensão e as relações que um conceito mantém com outros (BOUTINQUESNEL $^{48}$, 1985, p.26 apud BARROS, 2004, p.106). Barros assinala que o termo noção é visto pelos terminólogos brasileiros como mais vago do que o termo conceito; porém, diz a autora, o debate ainda está em aberto e cabe ao terminólogo decidir qual termo usar.

A análise do conteúdo semântico de um termo é chamada análise conceptual, análise nocional ou análise conceitual. Os conceitos exprimem-se na Terminologia de três maneiras:

a) conceito próprio de um domínio: conceito particular ou exclusivo de um domínio;

b) conceito emprestado: conceito que pertence mais especificamente a um outro domínio, mas é igualmente utilizado pelo domínio em estudo. Um exemplo é convés, que tem sua origem no domínio da construção naval e designa os pavimentos a bordo dos navios, mais propriamente os pavimentos descobertos ou semicobertos. Trazido para o domínio da extração petrolífera, designa os espaços abertos das plataformas. Mantém, assim, uma zona de intersecção semântica com o conceito de origem, mas possui traços semânticos que o primeiro não tinha, ou seja, o fato de os espaços abertos encontrarem-se em plataformas petrolíferas;

c) conceito que ultrapassa o domínio: conceito utilizado por vários domínios sem pertencer particularmente a um único. Ex.: embarcar / desembarcar. (BARROS, 2004, p.107. Grifos da autora.).

Barros ainda lembra que Cabré, por meio da Teoria Comunicativa da Terminologia (TCT) se opõe à determinação de domínios para o conceito, pois entende que existem usos de conceitos e não campos definidos de fixação de conceitos (BARROS, 2004, p.107).

Outros dois pontos importantes sobre os conceitos na Terminologia são as características e os sistemas de conceitos. As características são entendidas como “[...] representações mentais de propriedades de um objeto", podendo ser essenciais (comportam as essências dos conceitos e são responsáveis pela sua definição) ou secundárias (são complementares às características essenciais, sem uma importância fundamental na descrição do conceito) (BARROS, 2004, p.107). As características dos conceitos são responsáveis pela classificação de conceitos em genéricos e específicos,

\footnotetext{
${ }^{48}$ BOUTIN-QUESNEL, R. et al. Vocabulaire sytématique de la terminologie. Québec: Publications du Québec, 1985. (Cahiers de l'Office de La Langue Française).
} 
pela distinção de um conceito de outro e pelo estabelecimento de sistemas de conceitos (sistemas conceituais).

Na Teoria Geral da Terminologia (TGT), os conceitos, segundo Wüster (1998, p.21) são o ponto de partida para o trabalho terminológico. O objetivo da Terminologia seria, portanto, estabelecer "delimitações claras" entre os conceitos. A Terminologia, de acordo com Wüster, considera que termos e conceitos podem ser independentes um do outro.

Oposta à Lingüística saussuriana, a concepção de termo de Wüster caracteriza-se pela possibilidade de descrição de um conceito por meio de uma definição como passo anterior à própria relação conceito-termo. Em outras palavras, para Wüster, pode-se identificar um conjunto de conceitos de um domínio especializado, organizá-los em um sistema estruturado e defini-los sem mesmo identificar com precisão os termos que os designam. Haveria, portanto, uma total independência entre a expressão e o conteúdo. Essa concepção de signo distancia a Teoria Geral da Terminologia da Lingüística Geral. (BARROS, 2004, p.55-56).

Por outro lado, Wüster (1998, p.39) afirma que a Terminologia parte do conceito para buscar sua denominação, mas não descarta totalmente a idéia de denominação, por ser indispensável contar com ela ou com algum outro signo para identificar e "fixar" um conceito.

Wüster (1998, p.39. Grifos do autor), em um tópico chamado "conceito de conceito", diz que

Todo concepto, con excepción de los conceptos de objetos individuales, corresponde a los elementos comunes que los seres humanos perciben en un gran número de objetos y que utilizan como medio de clasificación mental (para entender) y, por consiguiente, también para comunicarse. Por lo tanto, el concepto es un elemento del pensamiento.

Pode-se notar, de acordo com Krieger e Finatto (2004, p.31), que a teoria de Wüster apresenta, além do fundamento normativo, uma perspectiva cognitiva ${ }^{49}$ que a diferencia da pragmática contemporânea, focada no uso dos conceitos, proposta por Cabré (2000) na chamada Teoria Comunicativa da Terminologia.

Segundo Barros (2004, p.55), Wüster

Concebia a Terminologia como uma ciência de caráter filosófico, que mantém relações privilegiadas com a Lógica, a Teoria da Classificação e a Lingüística (posteriormente também com a Informática). Sua relação com a Lingüística é, no entanto, ambígua, uma vez que se interessa praticamente apenas pelos termos, dissociando o léxico da gramática, do contexto e do

\footnotetext{
${ }^{49}$ É importante frisar que princípio cognitivo adotado por Wüster sobre a noção de conceito é idealista e distante de um cognitivismo de base social e empírica. (CABRÉ, 2000, p.75-76).
} 
discurso, vendo-os como unidades que existem e têm vida independente. Nesse sentido, não deve haver, segundo Wüster, termos polissêmicos, sinônimos ou homônimos.

Sem negar a importância de Wüster $^{50}$ para a construção da Terminologia moderna, Cabré (2000, p.69 e segs.) considera reducionista a Teoria Geral da Terminologia (TGT) porque ela busca a uniformização restritiva de tendência universalista. O problema da TGT, segundo Cabré (2000, p.74), está na confusão entre a língua ideal e a língua real, em confundir realidade com desejo. Apesar de sua base filosófica ser a lógica aristotélica, parece evidente que Wüster sofreu grande influência do positivismo lógico do Círculo de Viena (GALINSKI; BUDIN, 1998, p.15; CABRÉ, 2000, p.109); e suas preocupações estavam mais voltadas para os aspectos normativos do que teóricos. Em sentido mais amplo que o de Wüster (1998, p.39) e buscando uma teoria interdisciplinar e a integração da terminologia a uma pragmática da língua "real", Cabré entende que

[...] la noción de concepto puede integrar el objeto de la lingüística (dado que los signos lingüísticos son unidades dotadas de forma y significado), de la ciencia cognitiva (porque el concepto es el resultado de la conversión del conocimiento de los objetos), de la filosofía (que da cuenta de cómo nos aproximamos a la realidad), de la psicología (que analizará las operaciones intelectuales que realizamos para convertir la realidad en pensamiento), de la neuropatología (que estudia determinadas alteraciones, entre ellas la confusión de los conceptos), de la sociología (que podría analizar las diferentes percepciones de la realidad por parte de los grupos sociales), de la etnología (interesada por la percepción de la realidad como cultura), etc. (CABRÉ, 2000, p.84. Grifo da autora).

A concepção de Cabré (2000) com relação à noção de conceito deixa claro o distanciamento entre a TGT e a TCT. Para a autora, a TGT não se preocupava com o estudo da evolução dos conceitos, pois, os considerava estáticos (CABRÉ, 2000, p.112), sem relação direta com o universo sócio-cultural da "língua real". No mesmo sentido, Pozzi (2000, p.6) é enfática em afirmar que "Los conceptos como unidades ideales, fijas y universales no existen e por lo tanto no pueden ser la base de la investigación terminológica."

A "teoria" do conceito de Wüster tem função estritamente normativa e operacional. Seu enfoque estava na fixação de estruturas conceituais das áreas de especialidade bem definidas. Isso quer dizer que, para Wüster, segundo Cabré (2000, p.112), a “[...] función estricta de la terminología es la de etiquetar la denominación de

\footnotetext{
${ }^{50}$ Segundo Cabré (2000, p.73) Wüster "protagonizou” a ascensão da terminologia como disciplina, mas outros autores também foram importantes.
} 
los conceptos en la comunicación profesional y, por tanto, su valor comunicativo dentro del discurso profesional no es objeto de interés [...]"

A Teoria Comunicativa da Terminologia, por outro lado, procura relacionar e desenvolver diversos aspectos não previstos pela TGT, porém, Cabré (2000, p.113) também lembra que o enfoque cognitivo, linguístico e social da teoria de Wüster não deixou de sofrer críticas devido ao próprio declínio da concepção e condição especializada do conhecimento, na segunda metade do século $\mathrm{XX}^{51}$.

Devido à condição poliédrica e multifuncional da Teoria Comunicativa da Terminologia, os conceitos não são vistos como exclusivos de um domínio, mas usados por um domínio. Segundo Cabré (2000, p.124. Grifos da autora), "Un concepto puede participar en más de una estructura con el mismo o diferente valor. Los términos no pertenecen a un ámbito sino que son usados en un ámbito con un valor singularmente específico." A maneira como o conceito é usado em um determinado campo de especialidade é o que determina, entre outras coisas, o seu lugar na estrutura (sistema) conceitual e a identificação de suas relações com outros conceitos e em outras estruturas. $\mathrm{O}$ conceito deixa de ser um elemento fixo no sistema e passa a ser dinâmico como a própria linguagem na qual ocorre e se forma. A proposta de Cabré (2000, p.126) é a de "contemplar" o conceito em toda a sua diversidade e complexidade social e cultural, “[...] poniendo en relieve la dinámica del conocimiento y la circularidade del saber."

A TCT é um campo interdisciplinar e tem como parâmetros três teorias básicas: a Teoria do conhecimento, a Teoria da comunicação e a Teoria da linguagem. Das três, a teoria do conhecimento, segundo Cabré (2000, p.131), procura explicar como a realidade é conceitualizada, quais são os tipos de conceitualização e qual a relação entre os conceitos e suas prováveis denominações. Por outro lado, apesar de toda importância e do espaço dedicado ao conceito, pouco sobre a formação dos conceitos é discutida na Terminologia, pelo menos em Wüster (1998) e em Cabré (2000). Para Wüster, como

\footnotetext{
${ }^{51}$ Cabré (2000, p.114) lembra, novamente, que as críticas à TGT de Wüster não a invalidam como teoria e nem tem como objetivo desconsiderar a grande contribuição prestada por ela à Terminologia, mas apenas procura identificar insuficiências "conceituais" e "funcionais", fazendo um contraponto com as necessidades de uma linguagem real e com as diversas perspectivas interdisciplinares que se consolidaram na contemporaneidade.

Para nosotros no hay duda alguna de que la TGT es una teoría sistemática, coherente y válida para dar respuesta a un tipo de comunicación, la comunicación estandarizada; pero a pesar de ello pensamos que mantiene una serie de principios poco satisfactorios desde la perspectiva de la comunicación real, que incluye tanto la comunicación estandarizada como la espontánea. (CABRÉ, 2000, p.118).
} 
vimos, o conceito é o ponto de partida do trabalho terminológico, enquanto Cabré estabelece uma série de princípios teóricos e pragmáticos pelos quais os conceitos podem ser abordados. Não esclarece, porém, ao menos nas obras consultadas, como a formação de conceitos na linguística, por exemplo, influencia suas relações internas e externas com os conceitos formados na psicologia. Concorda-se com Cabré (2000, p.138) quando afirma que as relações entre os conceitos, devido a diversas perspectivas, vão além das relações lógicas e ontológicas e que este campo de estudo ainda é pouco explorado.

\subsection{Teoria (Analítica) do Conceito de Dahlberg}

Em 1972, duas palestras, "Teoria da classificação, ontem e hoje" e "O futuro das linguagens de indexação", foram proferidas por Ingetraut Dahlberg na Conferência Brasileira de Classificação Bibliográfica, realizada no Rio de Janeiro. A publicação das palestras ocorreu apenas em 1979, em Brasília, por meio do IBICT e da ABDF (DAHLBERG, 1979a; 1979b).

Nessas palestras, Dahlberg já se perguntava como resolver os problemas do processamento informacional em bases de dados e com que teoria se poderia obter melhores resultados. Uma das soluções propostas por Dahlberg foi buscar, por meio de uma teoria analítica, a compreensão da natureza dos conceitos - sistematizada na chamada Teoria do Conceito.

A Teoria do Conceito ou Teoria Analítica do Conceito de Dahlberg (1979b, p.6) parte da afirmação de que os conceitos são "[...] sínteses rotuladas de enunciados verdadeiros sobre objetos do pensamento: esses enunciados - asserções - levam ao reconhecimento ou à separação de características dos conceitos, que também podem ser consideradas como elementos dos conceitos."

O conhecimento se fixa pela linguagem. Há relação direta e dependente entre conhecimento e linguagem. Para Dahlberg (1978a, p.101), "Novos conhecimentos apareceram com novos elementos lingüísticos e também através destes tornaram-se mais claros e precisos". O crescimento do conhecimento se dá com a linguagem e o surgimento de novos elementos linguísticos é o resultado desse crescimento. Assim, "[...] a linguagem constitui a capacidade do homem de designar os objetos que o circundam assim como de comunicar-se com os seus semelhantes." (DAHLBERG, 1978a, p.101. Grifos da autora). Da mesma forma que tais objetos podem ser chamados 
de individuais e gerais, os conceitos que a eles se referem também podem ser designados conceitos gerais e conceitos individuais.

\section{Conceitos gerais e conceitos individuais}

O conjunto de enunciados verdadeiros sobre um determinado objeto ou coisa formal é constituído tanto por conceitos gerais como por conceitos individuais. Os conceitos individuais e os conceitos gerais são baseados em objetos individuais e objetos gerais.

Objetos individuais estão presentes em espaço e tempo definidos. Exemplo: este computador, esta mesa, este sofá, etc. Trata-se de uma experiência comum dos sentidos. Nesse caso, Dahlberg (1978a, p.101-102), baseando-se em Kant, diz que a experiência humana é "[...] condicionada pelas formas do tempo e do espaço ou que tempo e espaço são condições 'a priori' de nossa sensibilidade."

Ao contrário, os objetos gerais não necessitam das "formas" do tempo e do espaço, pois, eles definem grupos ou categorias. Partindo dessa diferenciação, Dahlberg relaciona "conceitos individuais", como aqueles que identificam um objeto específico no tempo e no espaço, e "conceitos gerais", como aqueles que identificam categorias ou grupos de objetos. Exemplo:

Quadro $1^{52}$. Conceitos Individuais e Gerais.

\begin{tabular}{|l|l|}
\hline \multicolumn{1}{|c|}{ Conceitos Individuais } & \multicolumn{1}{|c|}{ Conceitos Gerais } \\
\hline A UnB & As universidades \\
\hline $\begin{array}{l}\text { A partida de futebol entre o Flamengo e } \\
\text { o Fluminense no dia 15 de janeiro de } \\
1976\end{array}$ & As partidas de futebol \\
\hline $\begin{array}{l}\text { O descobrimento do Brasil no ano de } \\
1500\end{array}$ & As descobertas marítimas \\
\hline
\end{tabular}

Tanto os conceitos individuais como os conceitos gerais podem ser enunciados em linguagem natural. Exemplo:

\footnotetext{
${ }^{52}$ Todos os quadros de 1 a 19 têm por fonte Dahlberg (1978a).
} 
Quadro 2. Enunciados em Conceitos Individuais e Gerais

\begin{tabular}{|c|c|}
\hline Conceito & Enunciados \\
\hline $\begin{array}{l}\text { Individual: IBICT (Instituto Brasileiro } \\
\text { de Informação em Ciência e Tecnologia) }\end{array}$ & $\begin{array}{l}\text { - é uma instituição } \\
\text { - situada no Rio de Janeiro } \\
\text { - relacionada com a coordenação dos } \\
\text { sistemas } \\
\text { - de informação no Brasil } \\
\text { - possui cerca de } 60 \text { funcionários, etc. }\end{array}$ \\
\hline Geral: Instituição & $\begin{array}{l}\text { - é constituída por um grupo de pessoas } \\
\text { - que trabalham com determinada finalidade } \\
\text { - possuindo administração comum } \\
\text { - localizada em determinado lugar } \\
\text { - durante determinado tempo, etc }\end{array}$ \\
\hline
\end{tabular}

Tanto o conceito individual "IBICT" quanto o conceito geral "Instituição" têm elementos comuns. Os elementos que constituem os conceitos individuais podem ser "reduzidos" aos conceitos gerais que, por sua vez, são importantes para os processos classificatórios, pois, definem-se por categorias mais abrangentes. Na comunicação diária (linguagem natural) a precisão na definição dos conceitos gerais não é comum e nem requisitada, o que não ocorre com os conceitos utilizados em linguagens especializadas.

\section{Características dos conceitos}

Como pode ser notado com o exemplo sobre o IBICT, formar conceitos é reunir “enunciados verdadeiros a respeito de determinado objeto", fixá-los ou localizá-los dentro de um signo ou símbolo linguístico verbal ou não. Na síntese de Dahlberg:

Quadro 3. Níveis dos Conceitos.

\begin{tabular}{|l|l|l|}
\hline \multicolumn{1}{|c|}{ Nivel } & \multicolumn{1}{c|}{ Individuais } & \multicolumn{1}{c|}{ Gerais } \\
\hline \hline Objetos & Objetos Individuais & Objetos Gerais \\
\hline \hline Conceitos & Conceitos Individuais & Conceitos Gerais \\
\hline $\begin{array}{l}\text { Sinais } \\
\text { - Verbais } \\
\text { - Não-Verbais }\end{array}$ & $\begin{array}{l}\text { Nomes Individuais } \\
\text { Sinais Individuais }\end{array}$ & $\begin{array}{l}\text { Nomes Gerais } \\
\text { Sinais Gerais }\end{array}$ \\
\hline
\end{tabular}


A formulação de enunciados verdadeiros com os atributos dos conceitos permite que se identifiquem características que tanto serão específicas de um único conceito, como também serão compartilhadas por outros conceitos. A identificação de tais características ocorre por meio da Análise dos Conceitos.

Como método, a análise de conceitos é eficiente para a identificação de campos conceituais ou mapas de área. A identificação dos elementos que constituem os conceitos, segundo Dahlberg, depende do método analítico-sintético. Procura-se levantar atributos de um determinado objeto até a formulação do conceito, que será comparado com outros conceitos que possuam algum parentesco (mesmas características) com o primeiro.

Dessa análise, algumas características serão realçadas até a identificação de uma característica geral que contemple (hierarquicamente) todas as outras. A esta característica mais geral dá-se o nome de Categoria (conceito com maior extensão). Exemplo de Dahlberg (1978a):

Quadro 4. Exemplo de Categoria.

Um periódico é um documento que publica periodicamente

Um documento que publica periodicamente é um documento

Um documento é um suporte de informação

Um suporte de informação é um objeto material

Um objeto material é um objeto

Mesmo sem um nome que designe um conceito, é possível saber o que ele é e formulá-lo pelo conjunto de suas características (DAHLBERG, 1978a, p.103). Tipologicamente, as características podem ser simples (quadrado, incolor, colorido, redondo, etc) ou complexas (moldado em madeira, pintado com tinta vermelha).

Características como redondo, madeira, pintado com tinta vermelha, etc, podem ser enquadradas em categorias. As categorias aristotélicas são o suporte escolhido por Dahlberg para listar "todas as características possíveis." 
Quadro 5. Espécies de Características.

\begin{tabular}{|l||c|}
\hline \multicolumn{1}{|c|}{ Espécies de Características } & \multicolumn{1}{c|}{ Exemplos } \\
\hline Matéria (substância) & de madeira, de metal, de couro, de vidro, etc. \\
\hline Qualidade & $\begin{array}{l}\text { possuir determinada estrutura, determinada } \\
\text { forma, ser redondo, denso, colorido, etc. }\end{array}$ \\
\hline Quantidade (extensão) & Possuir comprimento, largura, peso, etc. \\
\hline Relação & $\begin{array}{l}\text { ser o dobro, ser mais largo, ser causa de, ser } \\
\text { condição de, etc. }\end{array}$ \\
\hline Processo (atividade) & Começar, continuar, terminar, realizar algo, etc. \\
\hline Modo de ser & estar em pé, sentado, voando, etc. \\
\hline Passividade & ser cortado, pressionado, etc. \\
\hline Posição & estar em cima, em baixo, etc. \\
\hline Localização (lugar) & estar em Brasília, no Rio de Janeiro, etc. \\
\hline Tempo & em fevereiro de 1978, etc. \\
\hline
\end{tabular}

Seguindo a mesma linha de relacionar diferentes espécies de objetos e conceitos, Dahlberg chama a atenção para a distinção entre características essenciais (que também podem ser características constitutivas da essência e características consecutivas da essência) e características acidentais (características acidentais gerais e características acidentais individualizantes). Para a autora, "A ordem das características depende sempre dos objetos cujos conceitos são constituídos pelas mesmas características." (Dahlberg, 1978a, p.103. Grifo nosso). Exemplo de espécies de características:

Quadro 6. Características Essenciais e Acidentais.

\begin{tabular}{|l|l|}
\hline \multicolumn{1}{|l|}{ Características essenciais (necessárias) } & Constitutivas da essência \\
\hline \multirow{2}{*}{$\begin{array}{l}\text { Características acidentais (adicionais ou } \\
\text { possíveis) }\end{array}$} & Consecutivas da essência \\
\hline & Acidentais gerais \\
\hline
\end{tabular}

O exemplo abaixo procura esclarecer a distribuição destas características em objetos materiais em geral e em minerais: 
Quadro 7. Características essenciais constitutivas.

\begin{tabular}{|c|c|}
\hline \multicolumn{2}{|c|}{ Características essenciais constitutivas } \\
\hline $\begin{array}{l}\text { OBJETOS MATERIAIS EM GERAL } \\
\text { - ser material } \\
\text { - ter uma estrutura }\end{array}$ & $\begin{array}{l}\text { MINERAIS } \\
\text { - composição química } \\
\text { - estrutura cristalina }\end{array}$ \\
\hline \multicolumn{2}{|c|}{ Características essenciais consecutivas } \\
\hline $\begin{array}{l}\text { OBJETOS MATERIAIS EM GERAL } \\
\text { - as propriedades físicas } \\
\text { - propriedades elétricas }\end{array}$ & $\begin{array}{l}\text { MINERAIS } \\
\text { - desvio dos raios luminosos; dureza; condutividade } \\
\text { - condutividade }\end{array}$ \\
\hline \multicolumn{2}{|c|}{ Características acidentais gerais } \\
\hline $\begin{array}{l}\text { OBJETOS MATERIAIS EM GERAL } \\
\text { - determinada forma } \\
\text { - falhas } \\
\text { - cor }\end{array}$ & $\begin{array}{l}\text { MINERAIS } \\
\text { - formas externas dos minerais } \\
\text { - deformações } \\
\text { - cor }\end{array}$ \\
\hline \multicolumn{2}{|c|}{ Características acidentais individualizantes } \\
\hline $\begin{array}{l}\text { OBJETOS MATERIAIS EM GERAL } \\
\text { - relação com determinado lugar } \\
\text { - relação com determinado tempo }\end{array}$ & $\begin{array}{l}\text { MINERAIS } \\
\text { - relação com determinado lugar } \\
\text { - relação com determinado tempo }\end{array}$ \\
\hline
\end{tabular}

Dahlberg (1978a, p.103) afirma, sobre o exemplo acima, que todos os minerais têm propriedades químicas e cristalinas e que a diferença entre os minerais depende da forma como as propriedades se apresentam. Características essenciais consecutivas e constitutivas são dependentes entre si; já as características acidentais e individualizantes dependem de questões externas e acidentes. Além dos minerais, lembra a autora, existem outros tipos de objetos, como plantas e produtos, que possuem características essenciais e acidentais que podem ser diferentes.

Não é sempre fácil identificar e determinar as características essenciais dos conceitos, mas, conhecê-las é importante para determinar suas próprias funções. Segundo Dahlberg (1978a, p.104) as funções exercidas pelas características dos conceitos são:

Quadro 8. Funções das Características dos Conceitos.

- Ordenação classificatória dos conceitos e respectivos índices;

- Definição dos conceitos;

- Formação dos nomes dos conceitos. 
Na ordem dos conceitos são observadas suas relações: conceitos diferentes podem possuir características iguais. Exemplo:

Quadro 9. Exemplo de Ordenação de Conceitos.

\section{CONCEITOS}

Semear

Colher

Transportar a colheita

Preparar o solo

Arar o solo
PROPRIEDADE COMUM

ATIVIDADE AGRÍCOLA

Os conceitos mencionados estão relacionados pela característica comum "atividade agrícola", mas, outras características também poderiam ser usadas para manifestar as relações entre os conceitos citados.

\section{Relações entre conceitos}

O estabelecimento das relações entre conceitos parte, de acordo com Dahlberg, das seguintes características comuns e logicamente possíveis:

Quadro 10. Relações Lógicas entre Conceitos.

\begin{tabular}{|l|c|c|c|}
\hline \multicolumn{3}{|c|}{ Relações lógicas } \\
\cline { 4 - 4 } & $\mathrm{A}(\mathrm{x}, \mathrm{x}, \mathrm{x})$ & $\mathrm{B}(\mathrm{x}, \mathrm{x}, \mathrm{x})$ & As características são as mesmas \\
\hline \hline identidade & $\mathrm{A}(\mathrm{x}, \mathrm{x})$ & $\mathrm{B}(\mathrm{x}, \mathrm{x}, \mathrm{x})$ & O conceito A está contido no conceito B \\
\hline \hline implicação & $\mathrm{A}(\mathrm{x}, \mathrm{x}, \mathrm{o})$ & $\mathrm{B}(\mathrm{x}, \mathrm{o}, \mathrm{o})$ & Nos dois conceitos algum elemento coincide \\
\hline \hline intersecção & $\mathrm{A}(\mathrm{x}, \mathrm{x}, \mathrm{x})$ & $\mathrm{B}(\mathrm{o}, \mathrm{o}, \mathrm{o})$ & $\begin{array}{r}\text { Os conceitos se excluem mutuamente. } \\
\text { Nenhuma característica em comum }\end{array}$ \\
\hline \hline disjunção & $\mathrm{A}(\mathrm{x}, \mathrm{x}, \mathrm{o})$ & $\mathrm{B}(\mathrm{o}, \mathrm{x}, \mathrm{o})$ & $\begin{array}{r}\text { O conceito A inclui uma característica cuja } \\
\text { negação se encontra em B }\end{array}$ \\
\hline
\end{tabular}

Os tipos de relações lógicas descritas acima podem ser aplicados, como afirma Dahlberg (1978a, 104), em classificações e em tesauros e subsidiam relacionamentos "semânticos" entre conceitos. Esses tipos de relacionamentos "semânticos" podem ser: relações hierárquicas (implicação); relações partitivas; relações de oposição (negação); relações funcionais (intersecção).

Relações hierárquicas (ou gênero/espécie) ocorrem em conceitos que além de possuírem características idênticas, um deles tem uma característica a mais do que o outro. Há uma cadeia que vai do conceito mais genérico (amplo, superior) para o mais 
específico (restrito, inferior). Exemplo:

Quadro 11. Relações Hierárquicas.

ÁRVORE
ÁRVORE FRUTÍFERA
MACIEIRA

Nas relações hierárquicas também podem ocorrer relações entre conceitos específicos do mesmo gênero (relações conhecidas como coordenadas):

Quadro 12. Relações Hierárquicas (Coordenadas).

\begin{tabular}{|ll|}
\hline \multicolumn{2}{|c|}{ ÁRVORE } \\
ÁRVORE FRUTÍFERA & ÁRVORE DE NOZES \\
MACIEIRA, PEREIRA, & AMENDOEIRA, AVELEIRA, \\
PESSEGUEIRO & NOGUEIRA \\
\hline
\end{tabular}

Relações partitivas estão direcionadas para relações todo/parte:

Quadro 13. Relações partitivas.

ÁRVORE

RAÍZES, TRONCO, GALHOS, FOLHAS, FLORES

Relações de oposição podem ser de "contradição" e de "contrariedade":

Quadro 14. Relações de Oposição.

CONTRADIÇÃO
NUMÉRICO --------------------NÃO NUMÉRICO
PRESENTE-----------------------AUSENTE
CONTRARIEDADE
BRANCO----------------------PRETO


Relações funcionais estão voltadas a processos. Para Dahlberg (1978a, 105) é possível conhecer o caráter semântico de tais relações por meio das "valências semânticas dos verbos". Exemplo de relações funcionais:

Quadro 15. Relações Funcionais.

PRODUÇÃO - PRODUTO - PRODUTOR - COMPRADOR

MEDIÇÃO - OBJETO MEDIDO - FINS DA MEDIÇÃO - INSTRUMENTO DE MEDIÇÃO - GRAUS DE MEDIÇÃO

Na concepção de Dahlberg, a valência semântica aparece no momento em que se procura preencher algumas lacunas entre os conceitos a partir de questões. Exemplo:

Quadro 16. Valência Semântica.

O que é medido?

- A temperatura

Com que instrumento é feita a medição?

- Com um termômetro

De acordo com que sistema?

- De acordo com o sistema Celsius

De que coisa é medida a temperatura?

- De uma célula viva

No caso acima, as questões indicam complementos que podem ser considerados para a individualização dos conceitos nas relações funcionais.

Os conceitos podem ser analisados em relação à intensão e à extensão. A intensão de um conceito é “[...] a soma total das suas características. É também a soma total dos respectivos conceitos genéricos e das diferenças específicas ou características especificadoras.” (DAHLBERG, 1978a, 105).

Exemplo: 
Quadro 17. Intensão do Conceito.

A intensão do conceito "casa" é a seguinte:

- Edifício;

- Habitualmente feito de pedra ou madeira;

- Contendo quartos e salas;

- Contendo portas e janelas;

- Contendo teto, etc.

A intensão do conceito "sol" é a seguinte:

- Estrela;

- Que se move ao redor da Via Láctea no espaço de tempo de 220 milhões de anos;

- É o centro do nosso sistema planetário;

- Possui um movimento de rotação ao redor do próprio eixo em 25 dias.

A soma dos conceitos específicos é a extensão do conceito. A extensão parte de conceitos mais genéricos e procura relacionar os mais específicos, com as mesmas características, e os individuais.

Exemplo:

Quadro 18. Extensão do Conceito.

a) extensão de um conceito genérico em relação com os conceitos específicos.

Casa

- Casa de pedra

- Casa de madeira

b) extensão dos possíveis conceitos individuais. Compreende os indivíduos para os quais é válida a predicação genérica do conceito.

Casa

- Casa do Presidente da República

- Casa do vizinho, etc.

Por fim, Dahlberg (1978a, p.105) apresenta as espécies de conceitos em categorias que podem ser combinadas entre si. 
Quadro 19. Espécies de Conceitos.

ESPÉCIES DE CONCEITOS

a) OBJETIVOS (plantas, produtos, papel, etc.)

b) FENÔMENOS (crescimento, chuva, tráfego, etc.)

c) PROCESSOS (imprimir, sintetizar, etc.)

d) PROPRIEDADES (cego/cegueira, suave/suavidade, etc.)

e) RELAÇÕES (causalidade, necessidade)

f) DIMENSÕES (espaço, tempo, posição, etc.)

Procurou-se apresentar até aqui os principais aspectos do artigo "Teoria do Conceito", publicado na revista Ciência da Informação em $1978^{53}$, recorrentemente citado nos estudos dos pesquisadores brasileiros da Ciência da informação.

Alguns trabalhos posteriores de Dahlberg (1978b; 1979a; 1979b; 1991; 1994) retomam as perspectivas acima descritas. Uma das características mais marcantes de sua teoria, além da sistematização de princípios de ordem lógica para os conceitos, talvez seja a definição de conceitos como "unidades de conhecimento" e, também, como já citado, que os conceitos são "[...] sínteses rotuladas de enunciados verdadeiros sobre objetos do pensamento."

Dahlberg (1978b, p.1-4) observa que os sistemas de organização de conceitos, notadamente o de Wüster e da ISO/TC 37, foram concebidos para as áreas da Tecnologia e das Ciências Naturais. Wüster (1998, p.147) concebe a normalização linguística constituída de dois níveis: normalização da linguagem das ciências naturais e normalização da linguagem técnica. Os conceitos dessas áreas, segundo Dahlberg, tendem à normalização e à padronização, tendo menor propensão à polissemia e à ambiguidade. Essa situação não ocorre nas Ciências Sociais, onde os conceitos são, por natureza, polissêmicos e ambíguos devido, talvez, à “[...] confiança quase exclusiva dos cientistas sociais no uso de termos derivados dos usos da língua comum [que] resulta numa proliferação de significados [...]". (DAHLBERG, 1978b, p.3). Conceitos como democracia, liberdade e capitalismo são sedimentados nas Ciências Sociais e, por outro lado, o nível de complexidade e a variação de seus significados e aplicações é

\footnotetext{
${ }^{53} \mathrm{O}$ artigo em questão é fruto de uma aula ministrada em 1975, por Ingetraut Dahlberg, no $8^{\circ}$ Congresso de Biblioteconomia e Documentação, ocorrido em Brasília. Nesse texto estão sintetizadas as bases da Teoria do conceito, largamente utilizada nas analises de conceitos na Organização do Conhecimento.
} 
extremamente ampla, como pode ser verificado na literatura da área. Como solução possível para esse "problema", Dahlberg (1978b, p.4) propõe um “[...] modelo analítico idealizado para elucidar a natureza e a estrutura dos conceitos [...]".

O conceito é definido como uma unidade de conhecimento por Dahlberg. Sua escolha é acompanhada pela indicação do que pode ser considerado conhecimento.

Se o conhecimento pode ser considerado a totalidade de proposições verdadeiras sobre o mundo, existindo - em geral - nos documentos ou nas cabeças das pessoas, então o conhecimento pode parecer existir também em todas as afirmações verdadeiras (em todos os julgamentos) e em todas as proposições científicas que obedecem a um postulado verdadeiro. (DAHLBERG, 1978b, p.5).

Dahlberg (1978b, p.6) considera necessário identificar um referente (idéias, objetos, fatos, leis, propriedades, ações, etc), fazer afirmações corretas, verificáveis e verdadeiras sobre ele, que possam ser transmitidas verbalmente por meio de um nome ou termo (Figura 1). Portanto, segundo Campos (2001, p.103), o conceito de Dahlberg é constituído pelo referente, suas características e a forma verbal pela qual é expresso (Figura 2).

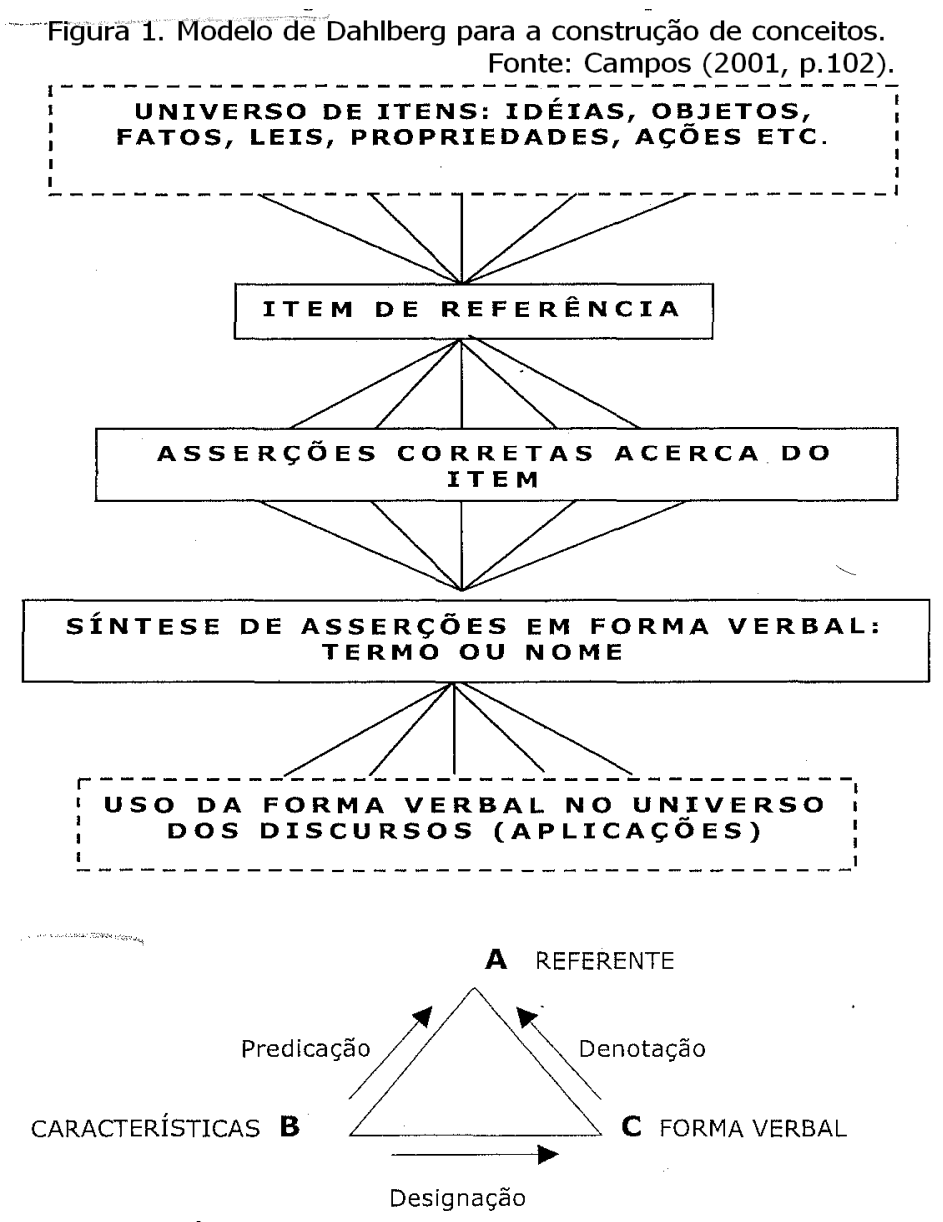

Figura 2. Triângulo de Dahlberg. Fonte: Campos (2001, p.103). 
Cada afirmação correta sobre o referente é um elemento de conhecimento sobre ele e o total de afirmações corretas sobre o referente forma a unidade de conhecimento, ou seja, o conceito.

Ranganathan (1967 ${ }^{54}$, p.81 apud CAMPOS, 2001, p.28), por sua vez, define conhecimento como "[...] a totalidade das idéias conservadas pelo ser humano [...]" que podem existir interna e externamente a ele.

A "totalidade de proposições verdadeiras" está mais próxima do conhecimento científico, em sentido forte e, "totalidade das idéias" está associada ao conhecimento que não opõe ciência e não-ciência. Para Ranganathan, o conhecimento é um "continuum dinâmico" configurado por um "Universo de assunto dinâmico, infinito, multidimensional e sempre turbulento." (RANGANATHAN, 1967, p.373 apud CAMPOS, 2001, p.31). Nesse sentido, pode-se dizer que Dahlberg não contempla em sua teoria aspectos dinâmicos, como o uso dos conceitos na linguagem, no universo do conhecimento. "Se nossas ciências são construídas sobre proposição e elas podem ser consideradas como unidades de conhecimento, então tais unidades devem ser passíveis de verificações científicas" (DAHLBERG, 1978b, p.5).

Dahlberg justifica sua afirmação sobre as proposições científicas e verdadeiras por meio da capacidade que o ser humano possui de fazer "[...] afirmações corretas sobre coisas reais (itens empíricos) e sobre idéias que só existem em sua mente [...]" (DAHLBERG, 1978b, p.5). A ciência não aceita com facilidade proposições "mentais" (sem verificação empírica) como verdadeiras. A proposição "O capitalismo seduz a democracia e reduz a liberdade" parece ser adequada em determinados contextos e situações, mas isso não significa que seja verdadeira. A idéia de verdade na ciência contemporânea se aplica de maneira cautelosa e baseada em evidências contextuais não definitivas. Uma lei da física, dados estatísticos, uma teoria, ou uma proposição, são aproximadamente válidos, como diriam Bachelard (1978; 2004) e Santos (2005), mas nunca absolutamente verdadeiros. A reunião de "enunciados verdadeiros" sobre determinado objeto carece, por parte de Dahlberg, de uma explicação de quais aspectos são fundamentais para se aceitar um enunciado como verdadeiro.

\footnotetext{
${ }^{54}$ RANGanathan, S. R. Prolegomena to library classification. Bombay: Asia Publishing House,
} 1967. 


\subsection{Ordem dos conceitos na Filosofia: comentários de Dahlberg}

Lógica, Teoria da Ciência, Epistemologia, Ontologia, Fenomenologia, Aletiologia e Metafísica são campos da Filosofia que se preocupam com o conceito e podem ter influência nos sistemas de ordenação (ordering) de conceitos. De acordo com Dahlberg (1991) cada disciplina atua sobre o conceito de formas distintas:

A) na Lógica, logos é palavra que representa o conceito. O conceito é composto por características, que também são conceitos, desde que estejam relacionadas com o objeto (subject) da predicação, o referente. Para Kant e Frege, os conceitos são baseados em funções. Segundo Kant (apud DAHLBERG, 1991, p.106) uma função é o ato de ordenar idéias diferentes em uma idéia comum. A partir de tais conceitos é possível produzir julgamentos sobre algo. Para Frege, o valor de uma função, ou seja, de um conceito, é sempre um valor de verdade. Um conceito, segundo Frege, é o significado de um predicado (A concept is the meaning of a predicate), que Dahlberg (1991, p.107108) exemplifica como segue:

Quando é afirmado que

- uma mesa é uma peça de mobiliário

- uma cadeira é uma peça de mobiliário

- um armário é uma peça de mobiliário

constrói-se o conceito (de classe) "móveis" com as espécies: mesas, cadeiras, armários.

Quando se diz que

- a mesa é feita de madeira

- a mesa é feita de metal

- a mesa é feita de pedra

distinguem-se várias mesas a partir de sua substância material, criando uma classe de mesas:

Mesas

- mesas de madeira

- mesas de metal 
- mesas de pedra

Predicações também podem ser partes (diferença entre "é feita de", acima, e ter, abaixo) de um item de referência (item of reference) ou objeto de uma declaração (subject of a statement):

- uma árvore tem um tronco

- uma árvore tem ramos

- uma árvore tem folhas

B) a Teoria da Ciência distingue os conceitos como: classificatórios (classificatory), comparativos e quantitativos ou métricos. A Teoria da ciência se preocupa, segundo Dahlberg (1991, p.109), com as atividades e resultados da ciência, com a "criação do conhecimento". Esse tipo de afirmação revela, segundo a autora, o que sabemos sobre algo, isto é, revela um elemento de conhecimento de um item de referência, levando-nos a reconhecer uma quantidade necessária de características predicativas acumuladas em uma "unidade de conhecimento". Os tipos de unidades de conhecimento (de conceitos) variarão de acordo com os tipos de itens de referência (um objeto, um lugar, uma propriedade, uma teoria, etc).

$\mathrm{Na}$ Teoria da Ciência, os conteúdos dos campos temáticos ou de assunto são determinados dentro das disciplinas, partindo de componentes típicos de uma série de outros componentes. Dahlberg lembra que é comum esses campos temáticos ou de assunto buscarem novos campos temáticos dentro da própria disciplina ou em outras disciplinas, quando adquirem suficiente maturidade.

C) a raiz grega de Epistemologia é episteme, que significa conhecimento de algo representado em declarações, proposições e juízos. Como na lógica, também há relação entre conceitos e linguagem. A diferença é que na epistemologia é possível comparar, mentalmente (ou cognitivamente), aquisições e ações anteriores. A análise das características de um conceito introduz uma espécie de ação cognitiva sobre o próprio conceito. Essa análise é chamada subjetiva por Dahlberg (1991, p.110) e, para transformá-la em objetiva é necessário definir essas características, divulgá-la e ter aceitação pública de uma comunidade de conhecimento.

Este processo pode envolver a análise das relações entre conceitos ou entre características de conceitos (as características de conceitos também são conceitos, como 
visto várias vezes ao longo da pesquisa). Dahlberg (1991, p.111-112) reconhece três tipos de relações, com quatro subdivisões cada uma:

1) Relação formal

- Identidade

- Inclusão

- Intersecção

- Exclusão

As relações formais são o primeiro passo a ser estabelecido nas relações conceituais. São formas simples de comparação de conceitos (compatibilidade de sistemas de ordenação).

2) Relações de forma e categoria

- Objeto

- Propriedade

- Atividade

- Dimensão

As relações de forma e categorias podem definir e distinguir conceitos de acordo com um objeto, uma propriedade, uma atividade ou uma dimensão (lugar, tempo e dimensão).

3) Relações materiais (relações de conteúdo)

- Relação genérica

Cada conceito possui um conjunto de características que definem níveis de generalidade e de especificidade, criando ladders (escalas/categorias) para os conceitos de gênero, espécie e individuais.

- Relação partitiva

Parte da idéia de que algo é "constituído por...". Mostra em diversos níveis todas as partes e subpartes que constituem um todo.

- Relação oposição/complemento

Basicamente são genéricos e procuram relações de oposição, contrariedade, 
analogia, relações dicotômicas e tricotômicas.

- Relação funcional

Definem-se por operações ou outro tipo de ação (geração, produção, preparação) sobre um objeto.

As relações materiais utilizam as relações de inclusão e intersecção para criar sistemas conceituais e tipos especiais de definições.

D) como ciência do ser em todas as suas formas e maneiras, a Ontologia se preocupa com os conceitos básicos de tudo o que se relaciona com objetos e pode ser ordenado em categorias diante da experiência (Aristóteles e Kant).

E) no campo da Fenomenologia, os estudos hermenêuticos interpretam os conteúdos dos termos (dos conceitos representados) nos textos. A Hermenêutica é conhecida como uma teoria de interpretação de textos. Segundo Dahlberg (1991, p.114), é um método útil à Fenomenologia e à Biblioteconomia e Ciência da Informação, que pode ser usado para a interpretação de significados de palavras (análise de assunto e tradução de linguagem natural para linguagem artificial).

F) Aletiologia ${ }^{55}$ é o campo de estudos filosóficos sobre a verdade. Buscar a verdade é importante para a Filosofia e para as ciências, sendo que a definição de conceitos e ordenação de sistemas conceituais fazem parte dessa busca. Diemer ${ }^{56}$ (1974 apud DAHLBERG, 1991, p.115) faz uma síntese dos conceitos de verdade, distinguindo-os da seguinte maneira:

1) Verdade substantiva

2) Verdade atributiva

- Verdade ontológica

- Verdade teórica

- Verdade material e semântica

- Verdade formal

- Verdade existencial

\footnotetext{
${ }^{55}$ De acordo com Abbagnano (2007, p.25) Aletiologia é uma “[...] espécie de anatomia dos conceitos que tem a finalidade de compreender os conceitos mais simples e indefiníveis."

56 DIEMER, A. FRENZEL, I. (Eds.). Philosophie. Das Fisher Lexikon, vol. 11. Frankfurt: Fisher Taschenbuch Verl. Ausg. Jan. 1974.
} 
- Verdade histórica

Diemer também apresenta alguns critérios de verdade:

Evidência

- Problemática (aberta, possível)

- Assertiva (afirmado empiricamente)

- Apodítica (absoluta, não refutável)

\section{Certeza}

\section{Verificabilidade}

G) a Metafísica, base de toda experiência e fornecedora dos princípios da cognição, não pode ser esquecida quando se fala de conceitos e sistemas conceituais. Dahlberg (1991, p.115-116) lembra que alguns dos grandes pensadores da área que criaram sistemas de "ordenação" (Dewey e Ranganathan) tiveram interesse pela metafísica. Essa influência teve muitas variações com o pragmatismo, de versão antimetafísica (unmetaphysical). Em defesa da metafísica, Dahlberg afirma que nunca se está livre dos pontos de vista metafísicos (idealismo, existencialismo, empirismo, realismo epistemológico, etc), porque eles pertencem à nossa própria natureza. Portanto, devemos ter clareza sobre a influência da metafísica sobre a organização do conhecimento e sobre o uso de sistemas ordenados de conceitos.

Seguindo essa mesma linha, Dahlberg (1991, p.116-117) defende ser necessário começar a construir sistemas de ordenação (ordering systems) de acordo com as sete subáreas descritas, tomando distância de sentimentos e "qualquer tipo de pragmatismo" (any kind of pragmatism). Dessa maneira, afirma a autora, seria possível construir sistemas de ordenação de conceitos harmonizados no que chama de "transcendentais" (transcendentals) - espécies de atributos divinos (divine attributes). Os transcendentais de Dahlberg são assim definidos:

Unum: o sistema deve ser visto por um único ponto de vista, como um todo original e estrutural;

Verum: o sistema dever ser verdadeiro, correspondente com a realidade e aplicável corretamente a todos os casos de uso.

Bonum: o sistema deve ser útil para todos. 
Pulchrum: o sistema deve ser "querido" por todos.

\subsection{Retrospectiva crítica do conceito}

María Pozzi no artigo "The concept of 'concept' in terminology: a need for a new approach" faz uma retrospectiva histórica sobre os conceitos na Filosofia, nas Ciências Cognitivas, na Neurologia e na Terminologia, levantando problemas de definição e fazendo uma análise crítica sobre as posições teóricas e normativas sobre os conceitos na Terminologia. Seu posicionamento pode ser estendido às áreas da Organização da informação e do conhecimento, reconhecidamente relacionada à Terminologia, à Linguística Documentária, a Análise Documentária, enfim, disciplinas do campo da Documentação.

Como na maioria dos trabalhos sobre o conceito, Pozzi (1999) parte da pergunta “O que são conceitos?", desenvolvendo outras questões que nos interessam, como: os conceitos existem realmente? O que eles representam? Como eles se relacionam com os objetos e com a linguagem? Como são concebidos e apreendidos? Como são armazenados e recuperados no cérebro?

É claro que nenhuma das perguntas acima terá uma resposta satisfatória e, muito menos, definitiva, mas a importância da recuperação dos pontos de intersecção de algumas disciplinas (em parte seculares) em torno do conceito nos proporciona o referencial necessário para entender que o conceito não é apenas objeto de operações semânticas e normativas.

Retornando à discussão sobre os conceitos, a Filosofia, como já vimos, foi a primeira área do conhecimento a se preocupar com a natureza e a origem dos conceitos. A Lógica se interessa por funções e atributos dos conceitos. A Psicologia Cognitiva estuda as categorias e as representações linguísticas do conhecimento por conceitos. As Ciências Neurológicas estão interessadas no estudo do armazenamento e recuperação dos conceitos por um viés físico e fisiológico. (POZZI, 1999).

A afirmação de que o conceito é a base de todo trabalho terminológico é contestada por Pozzi (2000)

[...] ya que como ha sido demostrado en varios trabajos de psicología cognitiva, no se sabe todavía cómo conceptualiza el ser humano aunque sí se sabe que cada persona conceptualiza de manera diferente y que aún una misma persona conceptualiza de manera diferente en distintas circunstancias. Por esto, los conceptos carecen de la precisión necesaria en terminología. (POZZI, 2000, p.3). 
A crítica de Pozzi (2000) pode ser aplicada à concepção de Wüster (1998), que considera o conceito como o ponto de partida para o trabalho terminológico. É importante destacar, logo de início, que Pozzi (2000) ao estabelecer sua crítica à posição, também adotada pela ISO 704 , da centralidade do conceito no trabalho terminológico, toma como base a psicologia cognitiva, deixando claro que diferentes abordagens (perspectiva que adotamos como hipótese) em torno do conceito têm influência nas teorias e ferramentas da Organização da informação e do conhecimento (questão que também verificaremos em Hjorland (2008)). Nessa mesma linha, outro exemplo, também dado por Pozzi (2000), contempla a crítica à norma que define a indispensabilidade e exaustividade da descrição das características do conceito, propostas na norma ISO 704, que, em certo sentido, já estavam presentes na proposta de teoria do conceito de Dahlberg (1978a) quando esta se refere à "soma total de características" e à fixação dos conteúdos dos conceitos por meio da linguagem. Vejamos o que nos diz Pozzi a esse respeito:

Los conceptos, de acuerdo con la ISO 704, están formados por un conjunto de características que a su vez consisten en la abstracción de las propiedades de una clase de objetos. Para caracterizar apropiadamente un concepto es necesario distinguir entre dos tipos de características: esenciales y no esenciales, siendo las primeras las que son indispensables para la comprensión del concepto. Sin embargo, para analizar un concepto correctamente, idealmente se deberían analizar exhaustivamente todas y cada una de las características que lo componen con el fin de asegurar que no se está dejando fuera ninguna característica esencial. La realidad nos demuestra que esto no siempre es posible: en primer lugar, cualquier investigación sobre un concepto dinámico tomaría una cantidad de tiempo infinita para asegurar que se incluyeron todas las características esenciales, dando como resultado que dicha investigación no fuera viable; y en segundo lugar, existen objetos que aunque sabemos que existen, no entendemos todavía lo que son, como 'vida', 'átomo', etc., y otros que aunque sabemos lo que son, cada quien los interpreta a su manera, como 'democracia', 'belleza', 'honestidad', etc.; entonces, cómo se pueden determinar las características esenciales de objetos que no podemos precisar bien lo que son? Por otra parte, en los años 60, se desarrollaron algunas teorías respecto a la conceptualización que afirmaban que la clase de objetos que corresponden a un concepto está limitada y delimitada por una lista de características que producen una intensión y extensión fijas, que es lo mismo que se afirma en la ISO 704 (pág. 4). En el campo de la psicología cognitiva, estas teorías fueron rechazadas ya que no existe base psicológica para determinar las características que forman los primitivos de esos conceptos ni tampoco se definieron las características de los objetos más simples. (POZZI, 2000, p.4).

Em vários momentos da presente pesquisa, houve a oportunidade de esclarecer as dinâmicas disciplinares sobre os conceitos que vão ao encontro da posição adotada por Pozzi. Falando do conceito e, conseqüentemente, de suas características e limites, 
acredita-se que o conceito é um exemplo da dificuldade de propor uma totalidade de características essenciais sem provocar a redução de sentido, favorecendo sua operacionalização em oposição à sua dinamicidade e abrangência.

As diferentes formas de concepção do conceito afetam direta e/ou indiretamente os ambientes nos quais os próprios conceitos são objetos de análise e uso. Como afirmamos em nossa hipótese inicial, acreditamos que diferentes abordagens sobre os conceitos também implicam diferentes propostas de teorias e instrumentos de organização da informação e do conhecimento.

Para Hjorland (2008), apesar de o conceito ser importante para a Organização do Conhecimento $^{57}$, em especial na construção de tesauros e em outras ferramentas semânticas, há uma diversificação no entendimento do próprio conceito. Nesse sentido, Hjorland estabelece um primeiro passo para uma análise mais precisa do conceito, ou seja, esclarecer por quais motivos um conceito será usado, identificando o tipo de trabalho a ser realizado, qual o conceito de conceito será adotado e como ele influenciará o desenvolvimento da tarefa.

Por isso, citando Soergel et al (2004) ${ }^{58}$, Hjorland (2008, p.1) afirma que "O maior desafio na recuperação da informação é a identificação de conceitos em um domínio de interesse específico." Mas, na visão do autor, a busca por um entendimento maior sobre o conceito passa, logo de início, por um erro. Tal erro é separar os estudos sobre semântica e significado das palavras dos estudos sobre o conceito. Para Hjorland isso não poderia acontecer, pois eles (os estudos) se referem à mesma coisa.

A concepção de que os conceitos são significados das palavras baseia-se na Linguística. Fugmann ${ }^{59}$ (2004 apud HJORLAND, 2008) aponta para a centralidade do

\footnotetext{
${ }^{57}$ Hjorland (2003) diz que o conceito de Organização do Conhecimento (Knowledge Organization - KO) adotado pela Biblioteconomia e Ciência da Informação está direcionado para a organização da informação sobre registros bibliográficos, índices de citação, etc, visando uma melhor recuperação da informação. Por outro lado, o autor afirma que o campo da Organização do Conhecimento é bem mais amplo, abrangendo a organização do conhecimento em instituições sociais, linguagens e sistemas simbólicos, sistemas conceituais, teorias, etc. No Brasil é mais comum utilizar o termo Organização e Representação do Conhecimento (ORC), mas parece que os fundamentos básicos da área são aqueles estabelecidos na Organização do Conhecimento. Porém, existem algumas questões que devem ser levadas em consideração, como a própria idéia de representação. (FUJITA, 2008).

${ }^{58}$ Soergel, D., Lauser, B., Liang, A., Fisseha, F., Keizer, J., \& Katz, S. (2004). Reenginnering thesauri for new application: the AGROVOC example. Journal of Digital Information, 4(4). http://jodi.tamu.edu/Articles/v04/i04/Soergel/

${ }^{59}$ Fugmann, R. (2004). Learning the Lessons of the Past. IN: The History and Heritage of Scientific and Technical Information Systems: Proceedings of the 2002 Conference, Chemical Heritage Foundation, eds., W. Boyd Rayward and Mary Ellen Bowden. Medford, NJ: Information Today, 168-181. Available at: http://www.chemheritage.org/events/asist2002/14-fugmann.pdf
} 
conceito no campo da informação e diz que os conceitos não dependem, necessariamente, de expressões lexicais, tanto em linguagem natural como técnica. Nesse mesmo sentido, afirma que, “[...] alguns conceitos nunca terão uma unidade lexical correspondente em linguagem natural, mas sim notações classificatórias." (FUGMANN, 2004 apud HJORLAND, 2008, p.1).

Hjorland (2008) dá como exemplo a palavra "escola" que pode representar conceitos diferentes como "local de aprendizagem" e "escola de pensamento". Da mesma forma, o conceito "escola de pensamento" pode ser expresso por diferentes palavras como "paradigmas" ou "perspectivas". Já nas classes dos sistemas de classificação os conceitos podem ser considerados iguais às notações. O conceito "psicologia" corresponde à classe 150 na CDD. Trata-se de dupla codificação, ou seja, sinonímia entre expressão verbal e notação numérica.

Com isso, Hjorland pretende ampliar a abordagem sobre o conceito, sem resumila a um léxico. Para o autor, uma concepção importante é proposta por Sowa ${ }^{60}(1984$, p.344 apud HJORLAND, 2008, p.2). Segundo Sowa:

Os conceitos são invenções da mente humana usados para construir um modelo de mundo. Eles empacotam a realidade em unidades discretas para posterior processamento, são poderosos mecanismos de apoio para a lógica, eles são indispensáveis para uma precisa e extensa cadeia de raciocínios. Porém, conceitos e perceptos não podem formar um perfeito modelo de mundo, - eles são abstrações que selecionam aquelas funcionalidades que são importantes para uma finalidade, mas ignoram os detalhes $\mathrm{e}$ complexidades que podem ser muito importantes para outras finalidades.

Apesar de Sowa (1984, p.344 apud HJORLAND, 2008) incorporar a idéia de que os conceitos são invenções da mente humana, de que os conceitos constroem modelos de mundo, que eles "empacotam" a realidade, que são indispensáveis para os raciocínios lógicos e que ignoram complexidades e detalhes que não estejam previstos em seus objetivos, é a idéia de finalidade que é ressaltada por Hjorland. A finalidade dos conceitos atende à perspectiva de uso de conceitos e está inserida na tradição pragmática, opondo-se à visão de universalidade dos conceitos, predominante na tradição clássica e racionalista.

Além de estabelecer uma dinâmica muito maior, a possibilidade de estar em contato permanente com acontecimentos da realidade, projetando-a em conceitos de

\footnotetext{
${ }^{60}$ Sowa, J. F. (1984). Conceptual structures. Information Processing in Mind and Machine. Reading, MA.: Addison-Wesley.
} 
acordo com objetivos e finalidades específicos, a pragmática desloca os conceitos do universal para o específico, delimitando e tornando-os claros e objetivos.

Mas, definir um conceito de acordo apenas com seu uso não é suficiente. Segundo Hjorland (2008, p.2) "Quando usamos linguagem e termos, realizamos algum tipo de ato, com a intenção de fazer alguma coisa. Os diferentes significados dos termos que usamos são ferramentas mais ou menos eficientes para ajudar a realizar aquilo que queremos fazer". Ou seja, aquilo que queremos fazer, que queremos realizar, nossos objetivos na verdade, é que concorrem para definir um conceito. Dessa forma, para Hjorland, citando a filosofia pragmática de Charles Sanders Peirce, o significado de um termo não é determinado apenas pelo seu passado, mas também pelo seu futuro.

Baseado em Smith, Ceusters e Temmerman ${ }^{61}$ (2005 apud HJORLAND, 2008, p.2), Hjorland aponta outras quatro perspectivas, além da pragmática e da racionalista, que podem ser destacadas na abordagem dos conceitos: a psicológica, a linguística, a epistemológica e a ontológica.

- a perspectiva psicológica vê os conceitos como entidades mentais, análogas às idéias ou crenças

- na perspectiva lingüística, os conceitos são significados para termos gerais

- na perspectiva epistemológica os conceitos são unidades de conhecimento

- na perspectiva ontológica os conceitos são abstrações de classes (gêneros/espécies), atributos ou propriedades (isto é, dos padrões invariantes gerais que correspondem às entidades no mundo.

De acordo com a teoria que se esteja usando para analisar os conceitos, muitas diferenças podem surgir, mas isso não significa que uma teoria do conhecimento não possa abarcar alguns ou todos os aspectos relevantes das perspectivas citadas. Dessa maneira, os conceitos podem ser o entendimento das pessoas e o resultado de abstrações que são expressas por termos gerais.

Hjorland concorda com a ênfase no realismo, porém afirma que as formas de entendimento dos conceitos não são necessariamente conflitantes. Quando Smith, Ceusters e Temmerman (2005 apud HJORLAND, 2008) dizem que os conceitos podem ser entendidos como:

\footnotetext{
${ }^{61}$ Smith, B.; Ceusters, W. \& Temmerman, R. (2005). Wüsteria. Proceedings of Medical Informatics Europe. Available: http://ontology.buffalo.edu/medo/Wuesteria.pdf
} 
- idéias na cabeça das pessoas

- $\quad$ significado das palavras

- conhecimento consensual entre especialistas de uma disciplina ou

- os tipos (classe/gênero/espécie) de entidades no mundo.

Este ponto de vista não está livre de problemas. Segundo Hjorland, existem diferentes pontos de vista sobre os conceitos psicológicos, diferentes visões da linguística, assim como diferentes visões da epistemologia e da ontologia.

Estes diferentes pontos de vista são interrelacionados (interligados) de uma maneira que um ponto de vista psicológico combina (coincide) com um ponto de vista linguístico que coincide com um ponto de vista epistemológico que coincide com um ponto de vista ontológico ou metafísico. Se este não for o caso, nenhuma das teorias poderia ser razoavelmente consistente. (HJORLAND, 2008, p.3).

Sobre as diferentes perspectivas de abordagem dos conceitos, Hjorland dá um exemplo do entrecruzamento de diversas disciplinas, partindo do inatismo dos conceitos:

A idéia do inatismo dos conceitos é relacionada ao cognitivismo na psicologia, à teoria linguística de Noam Chomsky, ao racionalismo na epistemologia e ao platonismo na metafísica. Correspondentemente, a teoria dos conceitos como enraizada na experiência individual é relacionada ao behaviorismo na psicologia e na linguística, ao empirismo na epistemologia e ao idealismo subjetivo na ontologia.

Em outras palavras: uma ontologia realista é uma importante base para a teoria do conceito. Tal projeto é, no entanto, relacionado a uma teoria realista de ambas psicologia, linguística, epistemologia e ontologia. A fim de desenvolver uma teoria consistente todos os quatro aspectos devem ser levados em consideração. (HJORLAND, 2008, p.3-4).

Hjorland defende, portanto, que uma teoria do conceito consistente é aquela que tenta integrar diversas concepções teóricas e filosóficas sobre o conceito. A adequação ou inadequação dos conceitos pode variar de maneira dinâmica e abrangente, pois a forma particular de classificar as coisas no mundo pode se inverter e/ou contradizer, de uma cultura para outra ou de uma sociedade para outra. Esta é uma questão voltada para a pragmática dos conceitos, que envolve um certo tipo de representação dos acontecimentos da realidade que se apresenta a uma determinada cultura e/ou sociedade. A forma de apresentação da realidade depende da maneira como tal realidade é conceituada e classificada. Em um sistema consistente, as classes de objetos devem ser formadas a partir dos traços que os unem diante de um determinado objetivo. Para Hjorland (2008, p.4) "Um objetivo comum ou um uso comum é o princípio que une as 
classes e que forma os conceitos."

Como já mencionado, a idéia de adequação e uso para um fim específico configura-se como uma visão pragmática dos conceitos. De acordo com Hjorland, tal visão é partilhada por pesquisadores das Ciências Cognitivas e da Inteligência Artificial, embora, para o autor, a relação homem-máquina tenha levado a simplificações. A operacionalização de conceitos, especialmente no ambiente de máquina, apenas pode ser realizada com alguma eficiência a partir da simplificação, fato que está muito aquém, e talvez nem possa ser comparado com a complexidade operada pelo cérebro humano ${ }^{62}$.

O que predomina para a operacionalização de conceitos é o paradigma adotado pelos domínios do conhecimento. Os conceitos científicos, por exemplo, são desenvolvidos a partir de opiniões científicas e se caracterizam de acordo com a teoria adotada para sua conceitualização. De acordo com esta conceitualização é que o conceito será classificado. "O conceito de 'ouro', por exemplo, é visto como um elemento químico pertencente ao grupo de metais de cunhagem, baseado na teoria atômica. Baleias são vistas como mamíferos, não como peixes, baseado na teoria evolucionária” (HJORLAND, 2008, p.4).

Ainda segundo Hjorland, se adotarmos o ponto de vista psicológico ou o ponto de vista realista para conceituar e classificar "baleias", teríamos que satisfazer algumas condições.

Do ponto de vista psicológico:

- [Baleias] são conceitos/idéias nas cabeças das pessoas (isto é, a capacidade de uma pessoa para identificar as baleias como entidades do mundo)

- O significado da palavra "baleia" é "uma espécie de mamífero"

- De acordo com especialistas em uma disciplina, baleias são mamíferos

\footnotetext{
${ }^{62}$ Sobre tal questão citamos Pinker (2004, p.11) que ao referir-se ao uso da linguagem pelo computador diz que "O conhecimento tácito de gramática de uma criança em idade pré-escolar é mais sofisticado que o mais volumoso manual de estilo ou o mais moderno sistema de linguagem de computador [...]". Ainda de acordo com o autor, "Depois de décadas de esforços, nenhum sistema de linguagem artificialmente planejado chega perto de reproduzir o homem de rua [...]" (PINKER, 2004, p.23). Este é apenas um exemplo, pois, nossa discussão gira em torno dos pontos de vista elaborados por diversas teorias do conhecimento sobre a formação de conceitos e não sobre a gramática da linguagem.
} 
- Baleias são tipos (classes/gêneros/espécies) de entidades no mundo

Do ponto de vista realista:

- Baleias são tipos (classes/gêneros/espécies) de entidades no mundo

- De acordo com especialistas de uma disciplina, Baleias são mamíferos (desde que os cientistas definam uma taxionomia biológica definindo baleias por gênero e espécie)

- O significado da palavra "baleia" é "uma espécie de mamífero" (a classificação científica vem do conhecimento geral e é refletida em uma linguagem geral)

- [Baleias] são conceitos/idéias nas cabeças das pessoas (isto é, a capacidade de uma pessoa identificar as baleias como entidades do mundo depende do conhecimento biológico do indivíduo).

Note-se que as posições estão invertidas: do ponto de vista psicológico, as baleias são conceitos que estão nas mentes das pessoas e depois são identificadas como entidades no mundo. Já na visão realista, as baleias existem como entidades no mundo e depois se transformam em conceitos nas mentes das pessoas.

Há no exemplo apresentado um ponto de discussão interessante sobre construções subjetivas e realistas de conceitos. Se os conceitos primeiro se apresentam como representações mentais ou se apresentam por meio da análise científica de objetos da realidade, são afirmações que não podem ser feitas separadamente, pois, elas se afetam mutuamente.

Para Hjorland (2008) a exatidão e a pontualidade dos conceitos terminam quando entram em conflito com outros conceitos desenvolvidos para a mesma finalidade. Isso ocorre quando os conceitos ultrapassam os limites de seus objetivos iniciais.

Exemplo:

Em agosto de 2006, a União Astronômica Internacional redefiniu o termo "planeta", e classificou Plutão juntamente com alguns asteróides como planeta anão. Neste caso, o conceito de espécie "planeta" foi redefinido, e consequentemente o sistema de classificação usado para classificar os corpos celestiais. (Podemos também dizer que o conceito de "planeta" foi modificado). Nem todos concordam com esta mudança na espécie de um 
conceito, mas o exemplo mostra como espécies de conceitos são construídas cientificamente de forma a servir nossa compreensão dos fenômenos. Uma maneira específica de definir um conceito ou uma espécie pode ser mais ou menos fundamentada e aceita, mas a definição não pode ser considerada como algo mas uma parte da construção representações científicas.

São inúmeros fatores e aspectos que poderiam ser incorporados aos pontos abordados acima, mas é importante frisar que todas as teorias e filosofias sobre o conceito enriquecem o campo da Organização da informação e do conhecimento. Se considerarmos, com Hjorland (2008), que os conceitos são os elementos básicos e essenciais das áreas do conhecimento, a organização do próprio conhecimento é, de certa forma, organização de conceitos que podem ser influenciados por todas as perspectivas que analisamos até o momento. 


\section{OS CONCEITOS NA ORGANIZAÇÃO DA INFORMAÇÃO E DO CONHECIMENTO: UMA ANÁLISE DE ARTIGOS DE PERIÓDICOS BRASILEIROS}

A identificação e discussão das abordagens dos pesquisadores brasileiros, da área da Organização da informação e do conhecimento, sobre o conceito, foram realizadas por meio da análise da produção científica sobre o tema. Assume-se, nesta pesquisa, que o pesquisador tece seu discurso a partir de um conjunto de influências teóricometodológicas que o identificam com uma determinada corrente de pensamento. No espaço científico, portanto, um artigo não é uma entidade solitária, mas participa, junto com outros artigos, do conjunto da literatura sobre um tema.

$\mathrm{O}$ autor de um artigo científico fundamenta suas opiniões em autores que o precederam. No universo do discurso científico, as influências teóricas e metodológicas se manifestam, via de regra, por meio de citações. Essas redes de relações constituem-se de pequenos "fios" que ligam pesquisadores, identificados por Spinak (1996, p.68) como "nós" (nodos), que representam entidades no processo de citação. As entidades são os autores, as revistas e as instituições.

A análise de citações é uma técnica tradicionalmente utilizada nos estudos bibliométricos para compreender, por meio da descrição das fontes utilizadas por um autor, a estrutura e o próprio desenvolvimento da ciência (PRIMO; STUMPF; CONSONI; SILVEIRA, 2008, p.1). De acordo com Spinak (1996, p.8-12) essa técnica vem sendo utilizada para realizar estudos sobre:

a) o conjunto de autores que contribuíram ou contribuem significativamente para uma disciplina;

b) a média de referências por documento;

c) a forma da literatura citada;

d) o núcleo de documentos principais em uma disciplina;

e) a distribuição geográfica dos documentos citados;

f) a distribuição, por idioma, dos documentos citados;

g) as datas das publicações citadas. 
Esse procedimento foi adotado nesta pesquisa porque permite identificar os autores que gozam de reconhecimento dentro de uma coletividade científica (NORONHA, 1998).

Há, porém, críticas à análise de citações. A principal delas refere-se ao fato de a técnica ter sido desenvolvida sem maior preocupação com sua validade epistemológica. Não se tem, por exemplo, o entendimento claro das motivações dos autores para fazer referências a determinados documentos e autores (SPINAK, 1996).

Para os críticos do procedimento, a referência bibliográfica não é simplesmente um ato de dar crédito a quem de direito, como se costuma afirmar. A citação pode estar relacionada, por exemplo, muito mais ao desejo de persuadir do que ao de reconhecer pesquisas e textos importantes em um dado campo científico.

Tanto os críticos quanto os defensores do método estão de acordo em pelo menos um aspecto: que a análise de citações não se presta a avaliar a qualidade dos trabalhos. Não se pode afirmar que um documento seja melhor do que outro porque cita determinados autores. É possível, apenas, identificar os autores mais citados e, com base nesse índice, fazer hipóteses sobre sua importância em uma determinada área de pesquisa (SPINAK, 1996, BRAMBILLA; VANZ; STUMPF, 2006).

Alguns problemas de ordem técnica são enfrentados na análise de citações:

○ citações incompletas: as bibliografias agregadas aos artigos muitas vezes cobrem não mais do que $30 \%$ das influências;

- citações enviesadas (citação somente do que reforça a argumentação);

- citações negativas.

Ressalvadas as limitações inerentes à técnica, procuramos, neste capítulo, identificar os autores da área da Organização da informação e do conhecimento mais frequentemente citados nas discussões sobre o conceito, nos artigos das revistas brasileiras de Ciência da informação.

\subsection{Etapas e técnicas de pesquisa}

A pesquisa empírica requer a definição de alguns protocolos básicos, apresentados a seguir: 


\subsubsection{Definição do universo da pesquisa}

O universo de pesquisa foi constituído das revistas brasileiras online de Ciência da Informação. A identificação das revistas foi feita por consulta ao site da Ancib (Associação Nacional de Pesquisa e Pós-Graduação em Ciência da Informação http://www.ancib.org.br/periodicos-em-ci) e ao Portal de Periódicos da Capes (Coordenação de Aperfeiçoamento de Pessoal de Nível Superior http://www.periodicos.capes.gov.br/portugues/index.jsp). Estão relacionadas no Quadro 1, abaixo, as revistas da área.

Quadro 1. Revistas brasileiras de Ciência da informação (on line).

1. Brazilian journal of Information Science (2006-2007)

2. Ciência da Informação (1972-2009)

3. DataGramaZero - Revista de Ciência da Informação (1999-2009)

4. Em Questão (2003-2009)

5. Encontros Bibli: revista eletrônica de Biblioteconomia e Ciência da Informação (1996-2009)

6. Informação \& Informação (1996-2008)

7. Informação \& Sociedade: Estudos (1991-2009)

8. Liinc em revista (2005-2009)

9. Perspectivas em Ciência da Informação (1996-2009)

10. Ponto de Acesso (2007-2009)

11. Revista ACB (1996-2009)

12. Revista Brasileira de Biblioteconomia e Documentação (2006-2008)

13. Revista Digital de Biblioteconomia e Ciência da Informação (2003-2009)

14. Revista Ibero-americana de Ciência da Informação (2008)

15. Transinformação (2002-2009)

A consulta ao site da Ancib e ao Portal de periódicos da Capes foi feita em setembro de 2008. A identificação dos artigos pertinentes ao tema realizou-se em 
outubro do mesmo ano. Em outubro de 2009 foi feita nova consulta às mesmas fontes para atualizar os dados. Ao final, a pesquisa abrangeu o período de 1972 a 2009.

Foram analisados os 356 volumes do período de cobertura. A revista com maior número de volumes analisados foi a Ciência da Informação (89 volumes); a revista com menor número de volumes analisados foi a Revista Ibero-americana de Ciência da Informação (01). A revista Ciência da Informação, uma das mais antigas, disponibiliza, em linha, todos os volumes publicados (1972 a 2009). A Revista Ibero-americana de Ciência da Informação é de circulação recente, tendo disponível para consulta apenas o volume publicado em 2008.

\subsubsection{Estratégia de busca}

Após a definição do universo da pesquisa e a identificação das revistas, foram estabelecidos os termos da estratégia de busca para localizar os artigos pertinentes ao tema. Num primeiro momento, a pesquisa foi feita nos motores de busca das próprias revistas, com exceção da revista Datagramazero, que é organizada por temas e editada em outro formato, sem ferramentas de busca. Neste caso, foi necessário consultar cada artigo individualmente.

As buscas foram realizadas como segue:

a) na primeira busca, foi utilizado o termo "conceito" no campo "Texto Completo" dos buscadores das revistas de Ciência da Informação on line.

b) as buscas foram replicadas com outras três variantes: conceitos; conceitual; conceituais, para garantir recuperação exaustiva.

c) foram realizadas buscas adicionais por meio de sintagmas, tais como: sistema de conceitos; modelagem de conceitos; recuperação de conceitos; organização de conceitos; relação de conceitos; teoria do conceito; modelagem conceitual; sistema conceitual; sistemas conceituais; relações conceituais; categorização de conceitos; categorizações conceituais; classificação de conceitos; classificações conceituais.

Em síntese: foram feitos, inicialmente, 4 turnos de busca por revista e buscas adicionais por meio de sintagmas para garantir a exaustividade do corpus. 


\subsubsection{Seleção dos artigos}

Na primeira seleção, foram identificados 110 artigos. (Tabela 1, Apêndice A). Foram lidos os resumos e identificadas as palavras-chave desses artigos para proceder à seleção e constituição do corpus.

Em seguida, foi usado o recurso "localizar e marcar", do editor de textos MS WORD, para marcar, nos textos, os termos "conceito" e as variantes - conceitos, conceitual, conceituais. Após esse procedimento, o corpus foi reduzido a 42 artigos:

Tabela 2. Artigos selecionados para o Corpus de análise.

1. ALVARENGA, Lídia. A Teoria do Conceito Revisitada em Conexão com Ontologias e metadados no Contexto das Bibliotecas Tradicionais e Digitais. DataGramaZero - Revista de Ciência da Informação, v.2, n.6, Dez. 2001. Acesso em 02/10/2008. Disponível em: http://www.dgz.org.br

2. ALVARENGA, Lídia. Representação do conhecimento na perspectiva da ciência da informação em tempo e espaço digitais. Encontros Bibli: revista eletrônica de Biblioteconomia e Ciência da Informação, Florianópolis, v.8, n.15, $1^{\circ}$ sem. 2003. Acesso em 02/10/2008. Disponível em: http://www.periodicos.ufsc.br/index.php/eb

3. ARAÚJO, Carlos Alberto Ávila. Fundamentos teóricos da classificação. Encontros Bibli: revista eletrônica de Biblioteconomia e Ciência da Informação, Florianópolis, v.11, n.22, $2^{\circ} \quad$ sem. 2006. Acesso em 02/10/2008. Disponível em: http://www.periodicos.ufsc.br/index.php/eb

4. AZEVEDO NETTO, Carlos Xavier de. A abordagem do conceito como uma estrutura semiótica. Transinformação, Campinas, v.20, n.1, p.47-58, jan./abr. 2008. Acesso em 02/10/2008. Disponível em: http://revistas.puc-campinas.edu.br/transinfo/index.php

5. AZEVEDO NETTO, Carlos Xavier de. Signo, sinal, informação: as relações de construção e transferência de significados. Informação \& Sociedade: Estudos, João Pessoa, v.12, n.2. 2002. Acesso em 02/10/2008. Disponível em: http://www.ies.ufpb.br/ojs2/index.php/ies

6. BATISTA, Gilda Helena Rocha. Redes de conceitos. Perspectivas em Ciência da Informação, Belo Horizonte, v.9, n.1, p.6-17, jan./jun. 2004. Acesso em 02/10/2008. Disponível em: www.eci.ufmg.br/pcionline

7. BIOLCHINI, Jorge Calmon de Almeida. Semântica e Cognição em Bases de Conhecimento: do vocabulário controlado à ontologia. DataGramaZero - Revista de Ciência da Informação, v.2, n.5, Out. 2001. Acesso em 02/10/2008. Disponível em: http://www.dgz.org.br

8. BRÄSCHER, Marisa. A Ambigüidade na Recuperação da Informação. DataGramaZero Revista de Ciência da Informação, v.3, n.1, Fev. 2002. Acesso em 02/10/2008. Disponível em: http://www.dgz.org.br

9. CAFÉ, Ligia Maria Arruda; BRATFISCH, Alline. Classificação analítico-sintética: reflexões teóricas e aplicações. Transinformação, Campinas, v.19, n.3, p.237-250, set./dez. 2007. Acesso em 02/10/2008. Disponível em: http://revistas.puccampinas.edu.br/transinfo/index.php

10. CAMPOS, Maria Luiza de Almeida. Modelização de domínios de conhecimento: uma investigação de princípios fundamentais. . Ciência da Informação, Brasília, v.33, n.1, p.22- 
32, jan./abr. 2004. Acesso em 02/10/2008. Disponível em: http://revista.ibict.br

11. CAMPOS, Maria Luiza de Almeida. Perspectivas para o estudo da área de representação da informação. Ciência da Informação, Brasília, v.25, n.2. 1995. Acesso em 02/10/2008. Disponível em: http://revista.ibict.br

12. CAMPOS, Maria Luiza de Almeida; GOMES, Hagar Espanha. Metodologia de elaboração de tesauro conceitual: a categorização como princípio norteador. Perspectivas em Ciência da Informação, Belo Horizonte, v.11, n.3, p.348-359, set./dez. 2006. Acesso em 02/10/2008. Disponível em: www.eci.ufmg.br/pcionline

13. CAMPOS, Maria Luiza de Almeida; GOMES, Hagar Espanha. Organização de domínios de conhecimento e os princípios ranganathianos. Perspectivas em Ciência da Informação, Belo Horizonte, v.8, n.2, p.150-163, jul./dez. 2003. Acesso em 02/10/2008. Disponível em: www.eci.ufmg.br/pcionline

14. CAMPOS, Maria Luiza de Almeida; GOMES, Hagar Espanha. Princípios de Organização e Representação do Conhecimento na Construção de Hiperdocumentos. DataGramaZero Revista de Ciência da Informação, v.6, n.6, Dez. 2005. Acesso em 02/10/2008. Disponível em: http://www.dgz.org.br

15. CAMPOS, Maria Luiza de Almeida; GOMES, Hagar Espanha. Taxonomia e Classificação: o princípio de categorização. DataGramaZero - Revista de Ciência da Informação, v.9, n.4, Ago. 2008. Acesso em 02/10/2008. Disponível em: http://www.dgz.org.br

16. CAMPOS, Maria Luiza de Almeida; SOUZA, Rosali Fernandez de; CAMPOS, Maria Luiza Machado. Organização de unidades de conhecimento em hiperdocumentos: o modelo conceitual como espaço comunicacional para a realização da autoria. Ciência da Informação, Brasília, v.32, n.2, p.07-16, maio/ago. 2003. Acesso em 02/10/2008. Disponível em: http://revista.ibict.br

17. DUARTE, Elizabeth Andrade; CERQUEIRA, Roberto Figueiredo Paletta de. Análise facetada: um olhar face a modelagem conceitual. Revista Digital de Biblioteconomia e Ciência da Informação, Campinas, v.4, n.2, p.39-52, jan./jun. 2007. Acesso em 02/10/2008. Disponível em: http://server01.bc.unicamp.br/seer/ojs/index.php

18. GALVÃO, Maria Cristiane Barbosa. Construção de conceitos no campo da ciência da informação. Ciência da Informação, Brasília, v.27, n.1, p.46-52, jan./abr. 1998. Acesso em 02/10/2008. Disponível em: http://revista.ibict.br

19. GOMES, Hagar Espanha; CAMPOS, Maria Luiza de Almeida. Tesauro e normalização terminológica: o termo como base para intercâmbio de informações. DataGramaZero Revista de Ciência da Informação, v.5, n.6, Dez. 2004. Acesso em 02/10/2008. Disponível em: http://www.dgz.org.br

20. KOBASHI, Nair Yumiko; SMIT, Johanna W; TÁLAMO, Maria de Fátima Gonçalves Moreira. A função da terminologia na construção do objeto da Ciência da Informação. DataGramaZero - Revista de Ciência da Informação, v.2, n.2, Abr. 2001. Acesso em 02/10/2008. Disponível em: http://www.dgz.org.br

21. LARA, Marilda Lopes Ginez de. Diferenças conceituais sobre termos e definições e implicações na organização da linguagem documentária. Ciência da Informação, Brasília, v.33, n.2, p.91-96, maio/ago. 2004. Acesso em 02/10/2008. Disponível em: http://revista.ibict.br

22. LARA, Marilda Lopes Ginez de. Novas relações entre Terminologia e Ciência da Informação na perspectiva de um conceito contemporâneo da informação. DataGramaZero - Revista de Ciência da Informação, v.7, n.4, Ago. 2006. Acesso em 02/10/2008. Disponível em: http://www.dgz.org.br

23. LARA, Marilda Lopes Ginez de. O processo de construção da informação documentária e o processo de conhecimento. Perspectivas em Ciência da Informação, Belo Horizonte, v.7, 


\begin{tabular}{|c|c|}
\hline & $\begin{array}{llllllll}\text { n.2, } & \text { p.127-139, jul./dez. 2002. Acesso em } & \text { 02/10/2008. } & \text { Disponível em: } \\
\text { www.eci.ufmg.br/pcionline }\end{array}$ \\
\hline 24. & $\begin{array}{l}\text { LARA, Marilda Lopes Ginez de. O Unicórnio (o Rinoceronte, o Ornitorrinco ... ), a Análise } \\
\text { Documentária e a Linguagem Documentária. DataGramaZero - Revista de Ciência da } \\
\text { Informação, v.2, n.6, Dez. 2001. Acesso em } 02 / 10 / 2008 \text {. Disponível em: } \\
\text { http://www.dgz.org.br }\end{array}$ \\
\hline 25. & 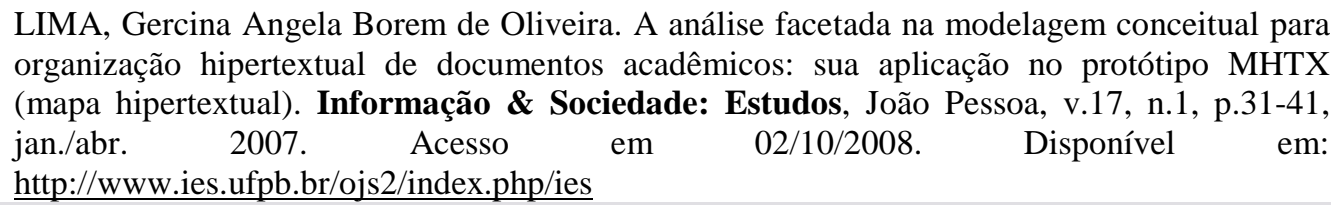 \\
\hline 26. & $\begin{array}{l}\text { LIMA, Gercina Ângela Borém. Análise facetada na modelagem conceitual de sistemas de } \\
\text { hipertexto: uma revisão de literatura. Perspectivas em Ciência da Informação, Belo } \\
\text { Horizonte, v.7, n.2, p.189-196, jul./dez. 2002. Acesso em 02/10/2008. Disponível em: } \\
\text { www.eci.ufmg.br/pcionline }\end{array}$ \\
\hline 27. & $\begin{array}{l}\text { LIMA, Gercina Ângela Borém. Mapa conceitual como ferramenta para organização do } \\
\text { conhecimento em sistema de hipertexto e seus aspectos cognitivos. Perspectivas em Ciência } \\
\text { da Informação, Belo Horizonte, v.9, n.2, p.134-145, jul./dez. 2004. Acesso em 02/10/2008. } \\
\text { Disponível em: www.eci.ufmg.br/pcionline }\end{array}$ \\
\hline 28. & $\begin{array}{l}\text { MARCONDES, Carlos Henrique; CAMPOS, Maria Luiza de Almeida. Ontologia e web } \\
\text { semântica: o espaço da pesquisa em ciência da informação. Ponto de Acesso, Salvador, v.2, } \\
\text { n.1, p.107-136, jun./jul. 2008. Acesso em } 02 / 10 / 2008 . \quad \text { Disponível em: } \\
\text { http://www.portalseer.ufba.br/index.php/revistaici }\end{array}$ \\
\hline 29. & $\begin{array}{l}\text { MONTEIRO, Silvana Drumond. O Ciberespaço: o termo, a definição e o conceito. } \\
\text { DataGramaZero - Revista de Ciência da Informação, v.8, n.3, Jun. 2007. Acesso em } \\
\text { 02/10/2008. Disponível em: } \underline{\text { ttp://www.dgz.org.br }}\end{array}$ \\
\hline 30. & $\begin{array}{l}\text { MORAES, Alice Ferry de; ARCELLO, Etelvina Nunes. O conhecimento e sua representação. } \\
\text { Informação \& Sociedade: Estudos, João Pessoa, v.10, n.2. 2000. Acesso em 02/10/2008. } \\
\text { Disponível em: http://www.ies.ufpb.br/ojs2/index.php/ies }\end{array}$ \\
\hline 31. & $\begin{array}{l}\text { MOREIRA, Alexandra; ALVARENGA, Lídia; OLIVEIRA, Alcione de Paiva. O nível do } \\
\text { conhecimento e os instrumentos de representação: tesauros e ontologias. DataGramaZero - } \\
\text { Revista de Ciência da Informação, v.5, n.6, Dez. 2004. Acesso em 02/10/2008. Disponível } \\
\text { em: http://www.dgz.org.br }\end{array}$ \\
\hline 32. & $\begin{array}{l}\text { MOREIRA, Alexandra; OLIVEIRA, Alcione de Paiva. Contribuição da terminologia na } \\
\text { modelagem de sistemas computacionais. DataGramaZero - Revista de Ciência da } \\
\text { Informação, v.6, n.5, Out. 2005. Acesso em 02/10/2008. Disponível em: } \\
\underline{\text { http://www.dgz.org.br }}\end{array}$ \\
\hline 33. & $\begin{array}{l}\text { MOREIRA, Manoel Palhares; MOURA, Maria Aparecida. Construindo tesauros a partir de } \\
\text { tesauros existentes: a experiência do TCI - Tesauro em Ciência da Informação. } \\
\text { DataGramaZero - Revista de Ciência da Informação, v.7, n.4, Ago. 2006. Acesso em } \\
\text { 02/10/2008. Disponível em: http://www.dgz.org.br }\end{array}$ \\
\hline 34. & $\begin{array}{l}\text { PAQUARELLI, Maria Luiza Rigo; TÁLAMO, Maria de Fátima Gonçalves Moreira. Sobre a } \\
\text { questão da designação terminológica da disciplina orientação bibliográfica. Ciência da } \\
\text { Informação, Brasília, v.24, n.2. 1995. Acesso em 02/10/2008. Disponível em: } \\
\underline{\text { http://revista.ibict.br }}\end{array}$ \\
\hline 35. & $\begin{array}{l}\text { PEREIRA, Edmeire Cristina; BUFREM, Leilah Santiago. Princípios de organização e } \\
\text { representação de conceitos em linguagens documentárias. Encontros Bibli: revista } \\
\text { eletrônica de Biblioteconomia e Ciência da Informação, Florianópolis, v.10, n.20, } 2^{\text {o sem. }} \text {. } \\
\text { 2005. Acesso em 02/10/2008. Disponível em: http://www.periodicos.ufsc.br/index.php/eb }\end{array}$ \\
\hline
\end{tabular}


36. RABELLO, Rodrigo. História dos conceitos e Ciência da Informação: apontamentos teóricometodológicos para uma perspectiva epistemológica. Encontros Bibli: revista eletrônica de Biblioteconomia e Ciência da Informação, Florianópolis, n.26, $2^{\circ} \mathrm{sem}$. 2008. Acesso em 02/10/2008. Disponível em: http://www.periodicos.ufsc.br/index.php/eb

37. SALES, Rodrigo de; CAFÉ; Ligia. Semelhanças e Diferenças entre Tesauros e Ontologias. DataGramaZero - Revista de Ciência da Informação, v.7, n.4, Ago. 2006. Acesso em 02/10/2008. Disponível em: http://www.dgz.org.br

38. SALES, Rodrigo. Suportes teóricos para pensar linguagens documentárias. Revista Digital de Biblioteconomia e Ciência da Informação, Campinas, v.5, n.1, p.95-114, jan./jun. 2007. Acesso em 02/10/2008. Disponível em: http://server01.bc.unicamp.br/seer/ojs/index.php

39. SMIT, Johanna W; TÁLAMO, Maria de Fátima Gonçalves Moreira; KOBASHI, Nair Yumiko. A determinação do campo científico da Ciência da Informação: uma abordagem terminológica. DataGramaZero - Revista de Ciência da Informação, v.5, n.1, Fev. 2004. Acesso em 02/10/2008. Disponível em: http://www.dgz.org.br

40. TÁlAMO, Maria de Fátima Gonçalves Moreira. A Pesquisa: recepção da informação e produção do conhecimento. DataGramaZero - Revista de Ciência da Informação, v.5, n.2, Abr. 2004. Acesso em 02/10/2008. Disponível em: http://www.dgz.org.br

41. TÁlAMO, Maria de Fátima Gonçalves Moreira; LENZI, Lívia Aparecida Ferreira. Terminologia e documentação: a relação solidária das organizações do conhecimento e da informação no domínio da inovação tecnológica. DataGramaZero - Revista de Ciência da Informação, v.7, n.4, Ago. 2006. Acesso em 02/10/2008. Disponível em: http://www.dgz.org.br

42. TRISTÃO, Ana Maria Delazari; FACHIN, Gleisy Regina Bóries; ALARCON, Orestes Estevam. Sistema de classificação facetada e tesauros: instrumentos para organização do conhecimento. Ciência da Informação, Brasília, v.33, n.2, p.161-171, maio/ago. 2004. Acesso em 02/10/2008. Disponível em: http://revista.ibict.br

\subsection{Análise do Corpus}

Definido o Corpus, foi dado início ao estudo de citações, para:

a) verificar a quantidade de citações e as relações entre os autores citados.

b) analisar os contextos em que aparecem os termos conceito (e variantes), com o objetivo de identificar como os autores citados e suas linhas teórico-metodológicas são abordados nos artigos.

Foram utilizadas as técnicas propostas por Noronha (1998), Primo, Stumpf, Consoni e Silveira (2008) e Silveira e Bazi (2009) para identificar a ocorrência e a frequência de autores no corpus.

\subsubsection{Padronização dos dados (reformatação)}

Depois de coletados, os dados foram formatados e tratados com os recursos do Word e do Excel para, em seguida, serem submetidos a processamento automático, com o software UCINET. Foi utilizado o recurso NetDraw do UCINET, para a geração de 
visualizações gráficas das relações entre os autores (HAYASHI; HAYASHI; LIMA, 2008; OLIVEIRA E SILVA; MATHEUS; PARREIRAS; PARREIRAS, 2006).

A formatação dos dados limitou-se à padronização de autoria dos documentos, tendo em vista os objetivos da exploração empírica. Consultando a literatura, pôde-se verificar que Noronha (1998, p.73-74) e Silveira e Bazi (2009, p.4) alertam para o fato de que abreviar os nomes ou prenomes dos autores pode fazer com que várias ocorrências de autores distintos sejam computadas como uma só, como no exemplo de Silveira e Bazi, abaixo.

PINHEIRO, L. V. R. (Lena Vânia Ribeiro Pinheiro)

PINHEIRO, L. V. R. (Lúcio Valber Rosset Pinheiro)

$\mathrm{Na}$ checagem das referências, constatou-se que nenhum documento apresentava a situação exemplificada acima. Optou-se, portanto, pelo uso das abreviaturas dos nomes e prenomes dos autores.

As abreviaturas foram usadas no tratamento das citações para manipulação no Excel e no software UCINET. Assim, a referência DAHLBERG, Ingetraut, foi padronizada para DAHLBERG, I. Outro aspecto que exigiu atenção foi a forma como os nomes e os sobrenomes dos autores estavam grafados. Nomes e sobrenomes que apresentavam variação foram padronizados. Por exemplo: WÜESTER, Eugen e WUSTER, E. - foram padronizados como WÜSTER, E.

Tomou-se também o cuidado de verificar, por meio de pesquisas em bibliotecas online e em outros documentos digitais, os nomes por extenso dos autores citados para, em seguida, corrigi-los e padronizá-los.

Por exemplo, em um dos artigos encontrou-se a referência:

- SANTOS, B. S. Introdução a uma ciência pós-moderna. Rio de Janeiro: Graal, 1989.

Na verificação constatou-se que a referência seria:

- SANTOS, Boaventura de Souza. Introdução a uma ciência pós-moderna. Rio de Janeiro: Graal, 1989.

Na padronização adotou-se o seguinte formato para esse autor: SANTOS, B. de S. 
A referência ANDERS et al. Die Zerstörung einer Zukunft. Rowohlt: Reinbek bei Hamburg, 1979. foi padronizada como ANDERS, G. et al.

Neste caso, Günther Anders é referenciado como o principal autor, porém, Matthias Greffrath também aparece, em outras referências pesquisadas na internet, como editor ou como co-autor da mesma obra. Foi esta a única anomalia identificada no corpus.

Seguindo as orientações propostas na literatura especializada (NORONHA, 1998; SILVEIRA; BAZI, 2009), no caso de autoria múltipla, todos os autores foram selecionados, sendo contabilizado 1 documento para cada autor. Por exemplo:

○ Cintra, A. M. M.; TÁllamo, M. de F. G. M.; LARA, M. L. G. de; KOBASHI, N. Y.

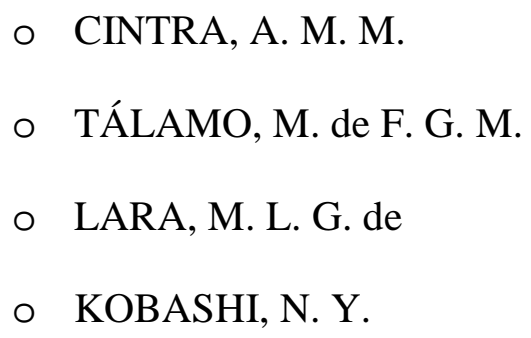

Nos casos de citações com et al, com base em Noronha (1998, p.73), foi feita pesquisa para incluir todos os autores. Exemplo:

○ CINTRA, A. M. M. et al.

$$
\begin{aligned}
& \text { CINTRA, A. M. M. } \\
& \text { ○ TÁLAMO, M. de F. G. M. } \\
& \circ \text { LARA, M. L. G. de. } \\
& \circ \text { KOBASHI, N. Y. }
\end{aligned}
$$

Quando o documento não foi encontrado ou quando houve alguma dúvida quanto às informações nele contidas manteve-se o et al na referência. Só houve um caso dessa natureza, já mencionado anteriormente.

Para a entrada de autoria de instituições, normas e dicionários, foram adotados os seguintes procedimentos:

- MINISTÉRIO DA EDUCAÇÃO E CULTURA. Secretaria da Educação Superior. Programa Nacional de Bibliotecas Universitárias. Manual de 
elaboração de tesauros monolíngues. Brasília: SESu, 1990. 78p. (SESu/NBU/Doc. PET/90/02).

Padronizado para: MINISTÉRIO...

Todos os artigos que citaram esse documento tiveram a entrada padronizada para “MINISTÉRIO...”. Na Tabela 3, Apêndice B, estão listadas as padronizações adotadas.

Após esses procedimentos de consistência, os dados foram inseridos no Excel para processamento. As citações foram separadas por artigos e agrupadas em ordem decrescente de frequência.

\subsubsection{Resultados da Análise de citações}

Foram computados 754 autores, com 1399 citações (Tabela 4, Apêndice B). O número de autores é menor do que o de citações porque a contagem foi realizada a partir do número de vezes que um mesmo autor aparece, de forma individual ou múltipla, nas referências dos artigos.

Dos 754 autores, 547 foram citados apenas uma vez. Com duas citações foram encontrados 106 autores, com três citações, 32 autores e com quatro, 22 autores. Com mais de cinco citações foram encontrados 47 autores.

No Gráfico 1, estão os autores citados dez ou mais vezes. A autora mais citada foi CAMPOS, M. L. de A. (Maria Luiza de Almeida Campos), com 42 citações, seguida por DAHLBERG, I. (Ingetraut Dahlberg), com 37 citações.

Verificou-se que entre os mais citados estão cinco autoras brasileiras:

- CAMPOS, M. L. de A. (Maria Luiza de Almeida Campos);

○ LARA, M. L. G. de (Marilda Lopes Ginez de Lara);

○ TÁlAMO, M. de F. G. M. (Maria de Fátima Gonçalves Moreira Tálamo);

○ GOMES, H. E. (Hagar Espanha Gomes);

○ KOBASHI, N. Y. (Nair Yumiko Kobashi).

Esse dado pode indicar que as pesquisas sobre o conceito, na literatura da área de Organização da informação e do conhecimento, no Brasil, apresentam certo grau de sedimentação e reconhecimento. 
Gráfico 1. Autores com 10 citações ou mais.

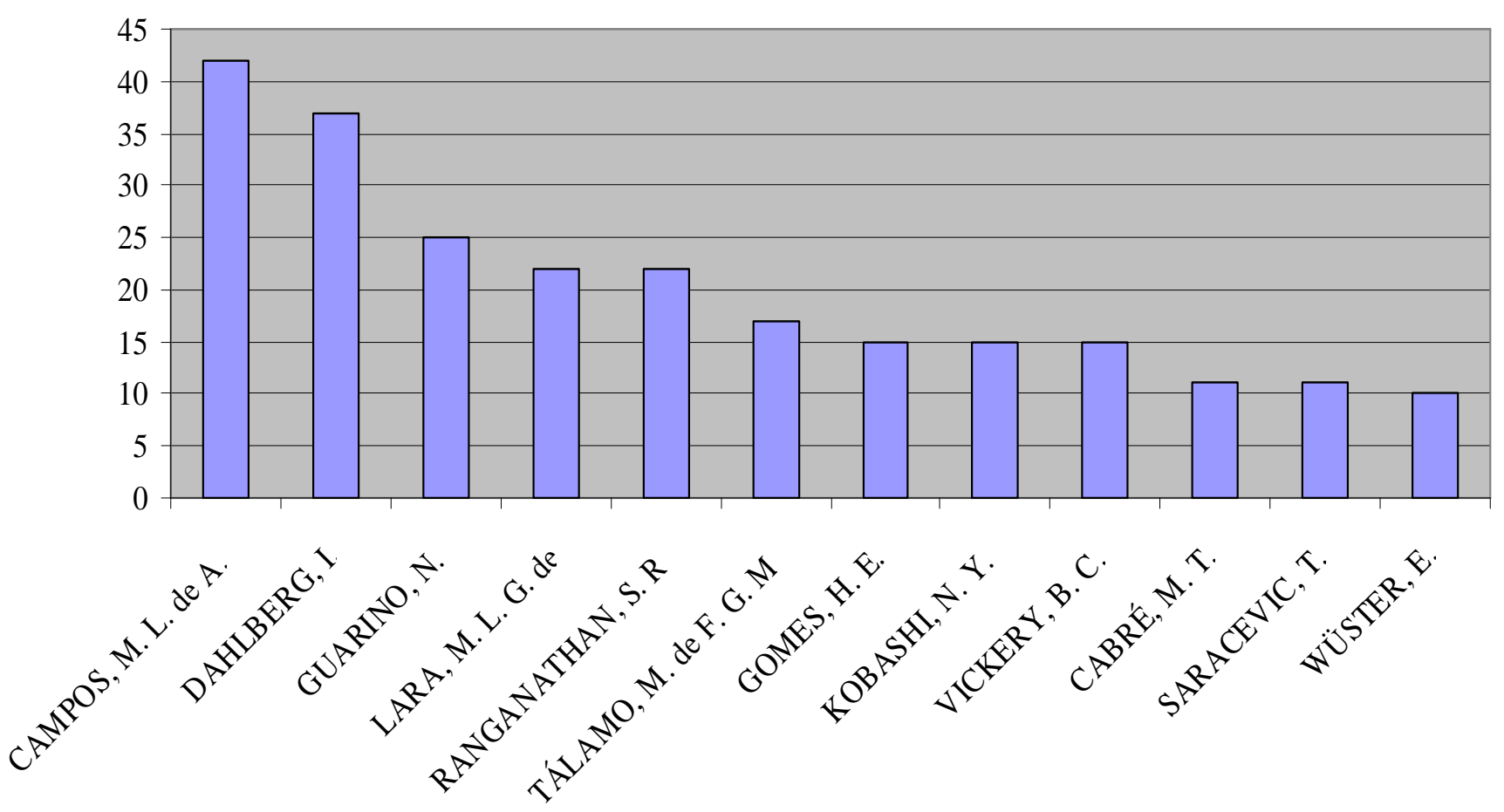

Ampliando o escopo de análise, a Figura 1, a seguir, apresenta as relações entre os 47 autores citados 5 vezes ou mais. É possível observar que quase todos os artigos se relacionam. 
Figura 1. Rede de autores com mais de 5 citações.

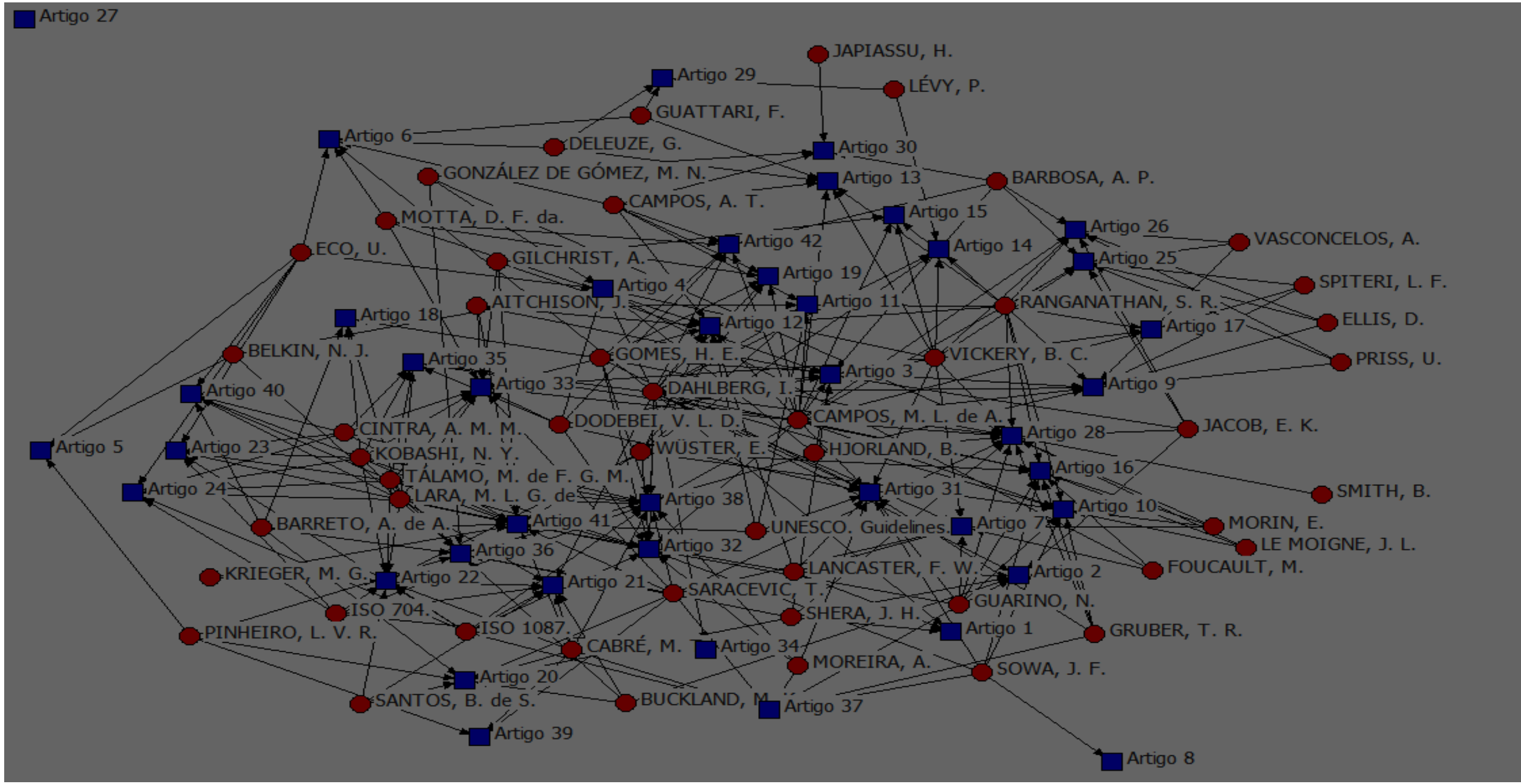


A FIG. 1 mostra que uma parte dos autores citados não é constituída de pesquisadores que atuam na área da Organização da informação e do conhecimento. É o caso de ECO, U. (Umberto Eco), LÉVY, P. (Pierre Lévy), SANTOS, B. de S. (Boaventura de Souza Santos), MORIN, E. (Edgar Morin), SARACEVIC, T. (Tefko Saracevic), BARRETO, A. de A. (Aldo de Albuquerque Barreto) e GONZÁLEZ DE GÓMEZ, M. N. (Maria Nélida González de Gómez). São pesquisadores do campo da Semiótica, da Filosofia, da Sociologia e Epistemologia da Ciência e da Teoria e Epistemologia da Ciência da Informação, citados com frequência como referenciais teórico-metodológicos das pesquisas da área de Organização da informação e do conhecimento.

Os resultados expostos no mapa acima indicam que os pesquisadores da área de Organização da informação e do conhecimento desenvolvem suas hipóteses de trabalho apoiados em amplos referenciais teóricos. A preocupação com a fundamentação teórica é, portanto, uma característica forte dos textos analisados.

Em relação ao objeto específico de pesquisa da presente tese - a presença e a ordem dos conceitos na Organização da informação e do conhecimento, o núcleo paradigmático das abordagens sobre o conceito pode ser verificado na FIG. 2. Esta figura apresenta as relações entre os autores com 10 ou mais citações no corpus. Dos 12 autores relacionados, apenas SARACEVIC, T. (Tefko Saracevic), como já mencionado, não se dedica de forma específica às pesquisas sobre o conceito. 
Figura 2. Relações entre os autores com 10 ou mais citações.

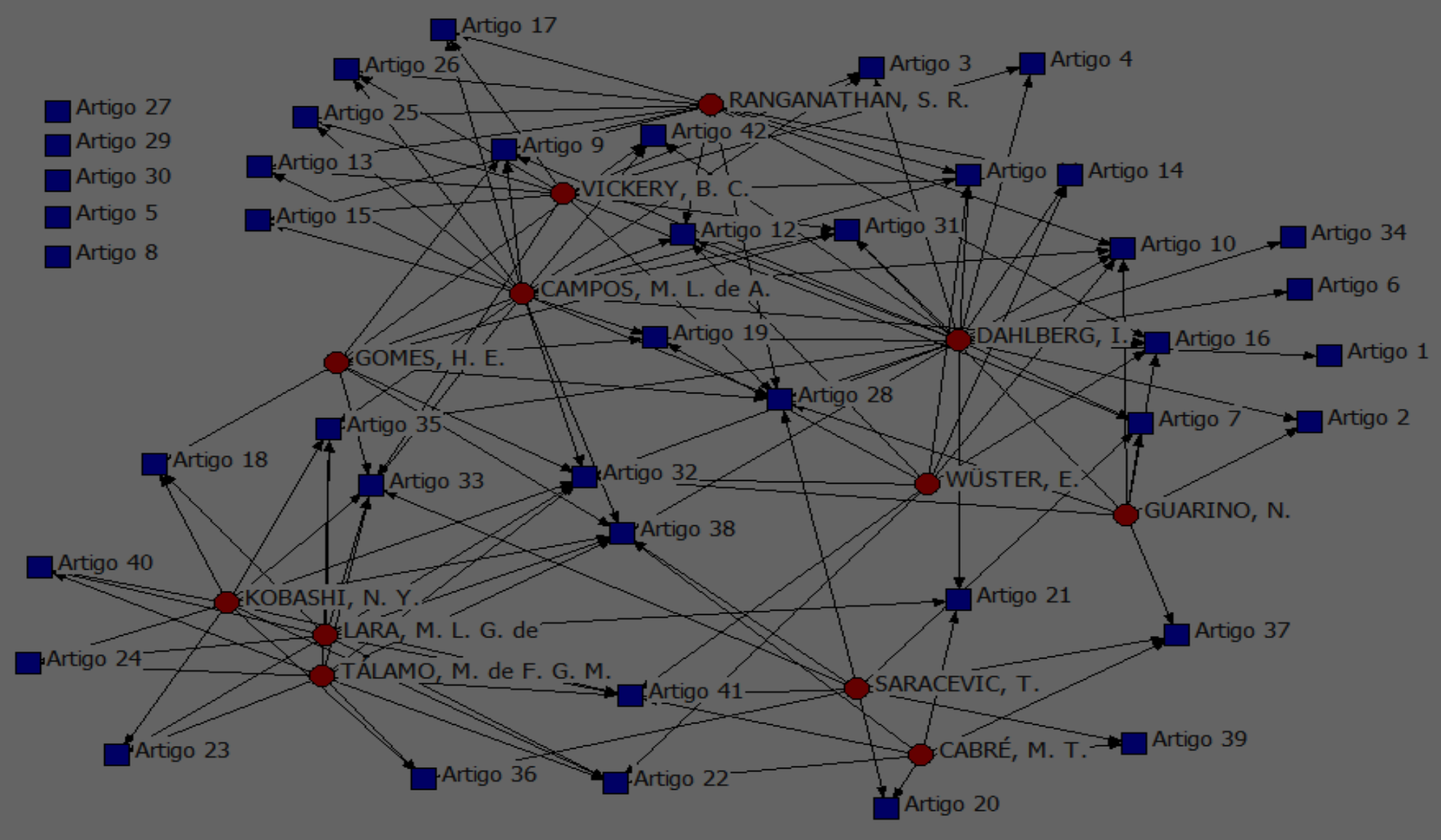


As abordagens sobre o conceito, segundo a FIG 2, baseiam-se largamente na Teoria Analítica do Conceito, de Ingetraut Dahlberg. Esta autora ocupa posição central na literatura da área, posição evidenciada tanto nas FIG 1 e FIG 2, quanto pelo número de vezes em que aparece relacionada, em "nós", aos artigos analisados. Observa-se, também que:

a) sempre que Campos é citada, Vickery, Dahlberg e Ranganathan também o são, evidência da estreita relação entre esses autores.

b) observa-se um fato curioso: que Campos, uma autora brasileira, é mais citada do que Dahlberg no conjunto analisado. Esse indicador pode ser atribuído a dois fatores: ao reconhecimento de Campos como autora importante da área, como também ao fenômeno da autocitação.

\subsubsection{Análise dos artigos.}

Para esta análise, foram inicialmente marcados, nos 42 artigos do corpus, os segmentos em que aparece a palavra conceito. Inicialmente, todos os trechos foram identificados, coletados, filtrados e alocados em tabelas.

Este procedimento visou a identificar como os autores discutem o conceito, isto é, como abordam o tema e quais são os autores que citam para fundamentar suas opções teóricas e metodológicas.

Primeiramente, consideramos os artigos que têm o conceito como principal objeto de análise e, em seguida, os artigos que, de alguma maneira, apresentam discussões sobre o conceito ou sobre aspectos correlatos. Os artigos, segundo essa perspectiva, têm a seguinte configuração:

a) artigos cujo principal foco de análise é o conceito: 4, 6, 18, 20, 36, 39, 40.

Artigos que embora não tenham o conceito como principal foco de análise, discutem importantes aspectos a ele relacionados: 1, 2, 3, 5, 7, 8, 9, 10, 11, 12, 13, 14, $15,16,17,19,21,22,23,24,25,26,27,28,29,30,31,32,33,34,35,37,38,41,42$.

Observa-se que dos 42 artigos analisados, 7 colocam o conceito como objetos principais de análise, embora esse aspecto não esteja explícito nos resumos. De fato, somente os artigos 4, 18 e 36 deixam claro, nos resumos, a abordagem sobre o conceito. Nos outros quatro artigos, a identificação foi feita por meio de leitura dos textos completos. 
Nos 35 artigos que não têm o conceito como foco principal de discussão, há grande variação nas formas de abordagem: em alguns casos, tópicos inteiros são dedicados ao conceito e, em outros, o termo aparece em parágrafos isolados.

Tanto os artigos específicos sobre o conceito como os outros que o abordam de forma subsidiária, podem ser caracterizados como de natureza teórico-epistemológica e/ou teórico-metodológica. Foram classificados como artigos teórico-epistemológicos aqueles nos quais os conceitos são analisados a partir de perspectiva filosófica, epistemológica, lingüística, lógica e terminológica. Foram considerados como de cunho teórico-metodológico os artigos com forte preocupação operacional, apresentando, por essa razão, análises estruturais, análise de redes, propostas de modelagem e de organização de sistemas de conceitos. São artigos voltados para a discussão das teorias da classificação, normas terminológicas e organização de conceitos em tesauros, taxonomias e ontologias.

\section{ARTIGOS TEÓRICO-EPISTEMOLÓGICOS}

Os artigos que podem ser incorporados à categoria de artigos "teóricoepistemológicos" são: 4, 5, 6, 18, 20, 21, 22, 23, 24, 29, 30, 36, 38, 39, 40, 41.

Apenas os artigos 4, 5, 6, 18, 29, 36 e 40 comportam o termo "conceito" ou alguma de suas variantes no campo das palavras-chave: formação de conceitos (artigo 4); análise de conceitos (artigo 5); redes de conceitos (artigo 6); construção de conceitos (artigo 18); conceito (artigo 29); história dos conceitos (artigo 36); conceito (artigo 40).

Apresentamos, a seguir, os artigos considerados teórico-epistemológicos. Cada artigo é antecedido de breve descrição do conteúdo e de extratos sobre o conceito.

a) Artigo 4: abordagem que discute a formação de conceitos em perspectiva semiótica, semântica e discursiva. Recupera autores como Gardin, Foucault, Cassirer e Peirce. Apresenta a Teoria do conceito de Dahlberg, embora não a confronte com as outras teorias. Propõe uma metodologia de análise do conceito com base na semiótica peirceana e na análise do discurso de Foucault. É o único artigo, dentre os selecionados, que toma o conceito como principal objeto de análise, discutindo variantes semióticas e discursivas sobre o conceito, diferenciando-se, portanto, de muitos artigos do corpus, que adotam perspectiva lógico-positivista. Os extratos coletados elucidam os aspectos identificados. 
[...] a conceituação e compartilhamento das representações sociais fazem com que seja necessário o entendimento do papel dos conceitos dentro da formação discursiva e do processo de transferência da informação em uma determinada comunidade. Para tanto, discute-se a formação e prática do discurso, sob o ponto de vista da teoria semiótica de Peirce (1977) e analisa-se a entidade conceito como estrutura semiótica, por meio da equiparação entre os elementos constitutivos do conceito e os do signo, enquanto estruturas de representação. (p.48)

[...] relaciona-se a formação de conceitos como um ato que é socialmente aceito e que se dá por meio e dentro de um processo de comunicação, conforme nos fala Peirce (1977), o que aproxima a idéia de formação do conceito à idéia de semiose [...]. (p.52)

De acordo com a teoria dos conceitos, definida por Dahlberg (1978c), a construção de conceitos deve possuir uma lógica interna que permita depreender a sua unidade representacional. Para tanto, os conceitos devem ser construídos, em função de sua precisão, a partir de enunciados aceitos como verdadeiros. (p.53)

Os conceitos estabelecem uma série de relações entre si que podem ser divididas como: relações lógicas, hierárquicas, partitivas, de oposição e funcionais (Dahlberg, 1978c). (p.53)

Os conceitos, assim entendidos, possuem propriedades que os tornam entidades definíveis, identificadas como: "fonte de saber, rígida definição, mantém muitas conexões, constituição muito específica, pertencente a uma certa categoria, etc." (Dahlberg, 1978b. p.15). Para isso, verifica-se o potencial de intenção e de extensão de um conceito. (p.53)

Os conceitos científicos possuem dois tipos básicos de características na sua constituição: as essenciais e as acidentais. (p.54)

[...] o papel dos conceitos está intimamente ligado à recuperação da informação. (p.54)

Para a efetiva transferência da informação, há necessidade de uma organização e classificação dos conceitos em unidades que possibilitam a interlocução entre membros de uma mesma comunidade discursiva. (p.54)

A definição pode ser encarada como a linha de limite, onde se dá a explanação do sentido de um conceito, com base nos seus objetos de referência, sendo indispensáveis na elaboração e comunicação dos discursos científicos e também como elementos para o crescimento de uma área do conhecimento. As definições são realizadas a partir de observações sobre o objeto, procurando extrair dele atributos, características que o façam de modelo de todo um conjunto de objetos, teoricamente pertencentes à mesma classe, expressas de forma discursiva. (p.54-55)

Como conceito, considera-se a definição de Dahlberg (1978a, p.5): “[...] unidade do conhecimento, compreendendo afirmações verdadeiras sobre um dado item de referência, representado por uma forma verbal”. (p.55)

[...] deve-se observar que conceito e signo se assemelham principalmente pelo processo de significação. Essa aproximação revela-se quando os conceitos são observados em seu contexto específico, ou seja, no cotidiano de sua prática, que se dá na esfera da construção dos discursos, onde se permite a permeabilidade e mutabilidade dos conceitos, enquanto formas físicas, e a relativização (Da Matta, 2000) da sua significação. (p.55)

A determinação das mathêsis de cada um dos conceitos efetua-se pela identificação dos principais atributos de referência que os compõem e definem, localizados dentro do conjunto de atributos definidores. (p.56)

Para o embasamento metodológico de um estudo que pretenda abordar a questão da análise dos conceitos, um dos pilares é a teoria semiótica, elaborada por Peirce (1985), que estabelece a tricotomia do signo, e a figura mais importante, para o presente caso, é o interpretante, que é visto como a instância onde há a construção do significado, da recuperação da Informação. (p.56)

b) Artigo 5: centra-se na abordagem semiótica peirceana do conceito. Relaciona questões relativas à semiótica da comunicação, princípios da lógica filosófica (Carnap, Wittgenstein, Quine, Russel) e da linguiística (Saussure e Barthes). 
Em uma perspectiva histórica, os primeiros registros que tratam da doutrina do significado vêm dos Estóicos (ABBAGNANO, 1982), que consideram o significado como aquilo que remete e aquilo que é, identificando dois elementos do significado: a Voz ou representação racional, e aquilo que é, ou sujeito, sendo o primeiro o conceito ou essência, e o segundo como objeto, com o significado em si residindo no primeiro. (p.6)

O que é entendido inicialmente como a dimensão semântica do processo sígnico - a relação possível de estabelecer a referência entre o signo e seu objeto (ABBAGNANO, 1982). Suas condições fundamentais estão presas a dois aspectos inseparáveis: o primeiro, um conceito ou essência, é a delimitação e orientação da referência; o segundo é o objeto ao qual a essência, nome ou conceito, é referido. (p.6)

Passando por vários autores, entre eles Hispano e Mills, a visão dicotômica do signo será tratada de modo mais contundente, dentro da lógica tradicional, diferenciando-se dois aspectos do significado (o do referente e da referência) e recorrendo-se à distinção entre os elementos do conceito, ora chamados de compreensão e extensão, ora de intenção e extensão, ora de conotação e denotação. (p.6)

\section{c) Artigo 6: Recupera autores como Aristóteles, Wittgenstein, Eco e Deleuze e Guattari}

(rizoma) para fundamentar a abordagem. Cita as fronteiras dos conceitos, discute os jogos de linguagem e semelhanças de família de Wittgenstein, apresentando, também, os rizomas de Deleuze e Guattari.

As classificações bibliográficas, embora sejam sistemas de conceitos, não são instrumentos de recuperação de informação, mas, antes, instrumentos de arranjo de coleções de documentos. Esperar desses instrumentos a capacidade de representar o conteúdo informacional de documentos para fins de recuperação da informação revela uma falha de concepção. Os tesauros, também sistemas de conceitos, por terem por base uma estrutura classificatória subjacente, podem herdar características restritivas relacionadas à representação do conhecimento e ao mapeamento da rede de relações entre conceitos. (p.7)

Os tesauros sistematizam conceitos, espelhando diferentes tipos de relações existentes entre os mesmos. Além das relações genéricas e partitivas, incluem relações de homonímia e sinonímia, e várias outras relações associativas. Os descritores arrolados, como termos autorizados, são apresentados em arranjo alfabético-estruturado, e possuem significado semântico e não apenas léxico. Em outras palavras, trabalham a nível conceitual e não verbal, estabelecendo rigorosa diferenciação entre termos e palavras, sendo essa sua principal característica. (p.8-9)

Apresentam uma complexa rede de referências cruzadas entre termos, para mapear outras relações entre conceitos - que não apenas as hierárquicas - mediando a comunicação entre produtores e usuários de informação. São linguagens dinâmicas, incorporando continuamente novos conceitos, e de conteúdo circunscrito a domínios específicos do conhecimento [...]. (p.9)

\section{b) Estruturação de conceitos}

A teoria de classificação tomou por empréstimo à lógica as técnicas para a construção das estruturas classificatórias, subdividindo classes em subclasses através da aplicação de características de divisão, $e$ seguindo princípios que regem a aplicação dessas características (princípios de modulação, de exaustividade, de exclusividade e de sequência útil). Esses princípios foram resgatados na filosofia clássica, especificamente em Aristóteles e Porfírio. (p.9-10)

Aristóteles, na busca por um método de inferência de definições, desenvolveu a teoria dos predicados, enumerando quatro predicados: o gênero, o próprio (propriedade), a definição e o acidente. Porfírio, retomando o trabalho de Aristóteles, enumera cinco predicados: gênero, espécie, diferença, próprio e acidente (Eco, 1990, p.85). (p.10)

O raciocínio de Eco parece similar àquele existente nas estruturas classificatórias facetadas, onde são possíveis as poli-hierarquias, ou seja, conceitos podem ser subordinados a mais do que um ponto na estrutura classificatória, que admite, ou reconhece, diferentes características de agrupamento ou critérios de subdivisão. Por exemplo, o conceito <filme> pode estar subordinado à classe <documentos imagéticos> (em contraposição à documentos textuais, por exemplo), e à classe 〈documentos especiais〉 (reportando-se ao tipo de suporte). 
Outra característica dos sistemas facetados referem-se a serem essencialmente analítico-sintéticos. Enumeram em facetas definidas segundo categorias de conceitos, apenas elementos conceituais simples, representados por símbolos notacionais, que são sintetizados para a representação dos assuntos compostos. Pode-se, assim, vê-los como sistemas passiveis de apresentar "estruturas sensíveis aos contextos, e não um dicionário absoluto" (Eco, 1990, p. 101). (p.12)

Wittgenstein (1995, p.229-230, IF, I, 68) também sustenta essa idéia dentro da teoria dos jogos de linguagem. Um conceito não é necessariamente a soma de conceitos parciais correspondentes. Pode-se fixar as fronteiras de um conceito, e usar uma palavra para designar um conceito com fronteiras fixas, mas também pode ser usada de tal maneira que o âmbito do conceito não seja delimitado por uma fronteira.

Bloor, em capítulo sobre jogos de linguagem e forma de vida observa que os conceitos em um jogo de linguagem são não circunscritos. Nos jogos de linguagem os conceitos funcionam livres e não nos limites determinados pelas cadeias de conceitos arrolados numa classe de referência ou de extensões semânticas (Bloor, 1983, p. 29). (p.12)

Segundo Wittgenstein, os jogos de linguagem são dinâmicos e múltiplos, "novos jogos de linguagem... surgem, e outros tornam-se obsoletos e esquecidos" (Bloor, 1983, p. 25). Assim, os tesauros precisam também ser linguagens dinâmicas, em constante processo de atualização, para poder acompanhar o processo de produção do conhecimento, incorporando novos conceitos e relações. (p.13).

Para Wittgenstein (1995, p. 207, IF, I, 43) "o sentido de uma palavra é o seu uso na linguagem. E a denotação de um nome explica-se, por vezes, ao apontar-se para seu portador." O autor aborda não só da ligação palavra-objeto, mas também sua contextualização. (p.13)

Bloor (1983, p. 25), analisando o finitismo em Wittgenstein diz que devemos pensar o significado estendendo-se tão longe quanto, mas não além de, uma gama finita de circunstâncias na qual uma palavra é usada. Acrescenta ao finitismo as noções de critério e de sintomas como pistas identificáveis usadas para justificar o uso de uma palavra ou aceitar uma classificação. Operam como convenções e não podem ser entendidos fora do contexto [...]. (p.14)

[...] Wittgenstein (1995, p. 239, IF, I, 79) explica "a flutuação das definições científicas: o que hoje é considerado verificado ser um aspecto concomitante do fenômeno A, será usado amanhã na definição de A."

Para Bloor, Wittgenstein unindo a noção de critério como instituição social à doutrina da semelhança familiar, reforça o caráter convencional da aplicação de conceitos.

Segundo a teoria de aplicação de conceitos de Wittgenstein, a melhor forma de descrever as bases de um agrupamento é pela metáfora da semelhança familiar. (p.14)

O pensamento de Wittgenstein foi contestado através da objeção de que, explorando-se todos os tipos de similaridades, nossos agrupamentos poderiam incluir tudo. Por exemplo, “uma faca é igual a um garfo por que ambos são usados para comer; mas ambos são iguais a uma chave de fenda por que são metálicos..." (Bloor,1983, p. 31). (p.14)

O primeiro a fazer essa crítica foi Vygotsky, que chegou a idéia de semelhança familiar mais ou menos ao mesmo tempo de Wittgenstein. Vygotsky considerou esses julgamentos de similaridade como pseudoconceitos, característicos de um estágio particular do desenvolvimento da criança. Para ele os conceitos genuínos usados pelos adultos resultam de uma classificação disciplinada e fixa, evitando conexões em elos e agrupamentos sincréticos. (Bloor,1983, p. 31-32). (p.14)

Bloor (1983, p. 32-33) aponta a existência de convenções sociais implícitas em todos jogos de linguagem. "O que a teoria da semelhança familiar faz, portanto, é trazer de maneira clara e simples os aspectos sociais e convencionais da aplicação de conceitos.” (p.15)

O usuário da língua é treinado no corpo de uma prática convencionalizada, e o mesmo acontece com as comunidades científicas de diferentes domínios. É o jogo de linguagem que explora as semelhanças entre conceitos de uma maneira particular, e sanciona o uso. (p.15)

Deleuze e Guattari pensam o processo de produção de conhecimento fazendo um[a] analogia com os rizomas e descrevem os princípios de conexão e heterogeneidade, da multiplicidade, da ruptura asignificante, e da cartografia e do decalque. (p.15) 
d) Artigo 21: tem foco na discussão das definições de conceitos no contexto do trabalho terminológico, estabelecendo distinção entre termo e palavra. Para isso, menciona os contextos de uso da linguagem e de conceitos e seus aspectos filosóficos, lingüísticosemânticos e sociológicos.

[...] a definição desempenha papel crucial na organização dos termos, afetando a estruturação do campo nocional das linguagens documentárias. Nem sempre, porém, podemos contar com definições claras, seja pela ausência de dicionários técnicos que auxiliem o trabalho de organização das linguagens, seja pela dificuldade de delimitação dos conceitos ou noções. Esse último aspecto explica, por exemplo, o fato de que a tarefa de organização de termos nas áreas das humanidades seja mais complexa. (p.92)

O trabalho terminológico de definição tem no conceito seu ponto de partida. Segundo as normas terminológicas, o conceito é uma unidade abstrata criada a partir de uma combinação única de características. Os conceitos são representados pelos termos, que são designações verbais. O termo é considerado a unidade mínima da terminologia (ISO 704; ISO 1087-1). Mais especificamente, o termo é uma designação que corresponde a um conceito em uma linguagem de especialidade. (p.92)

Uma palavra tem propriedades (como em um dicionário de língua), mas tem muitos significados, porquanto são elementos do léxico da língua. Um termo, ao contrário, é uma palavra contextualizada no discurso, tendo, conseqüentemente, um referente de interpretação. (p.92)

A literatura terminológica clássica privilegia o conceito de objeto afirmando que essa noção é fundamental em terminologia porque permite realizar a distinção entre trabalho terminológico e trabalho lingüístico. Se na lingüística não há primazia do significado sobre o significante, na terminologia a forma significante não é fundamental: há primazia do conceito sobre a forma. (p.92)

Para a lingüística, o importante é a pergunta "o que significa" - que remete ao uso que faço da palavra; já para a terminologia, interessa a relação da palavra com o que está fora da linguagem - "o que é" (Dubuc, 1977; Rondeau, 1984). (p.92)

[...] no trabalho lexicográfico, o interesse é voltado às propriedades da palavra; na atividade terminológica, às propriedades do objeto dentro de um campo do saber ou de atividade. Isso explica o privilégio da lógica para a organização das terminologias, por meio da identificação das relações entre as propriedades do objeto. (p.92)

[...] a terminologia clássica nascida de Wüster considera primeiramente o conceito, atribuindo à língua apenas a função designacional. Como conseqüência, não observa a prioridade da linguagem enquanto instrumento de comunicação. Todavia, para a lingüística estrutural, a função referencial da língua é a menos importante, mas é ela que é enfatizada pela terminologia clássica.

Sublinhando a função referencial da língua, tal terminologia pretende enfatizar a referência, ou o elemento que está fora da língua. (p.92)

A referência dos termos na terminologia é formulada mediante uma operação de definição. Uma definição é um enunciado que descreve um conceito permitindo diferenciá-lo de outros conceitos associados [...]. (p.93)

A definição terminológica (ou terminográfica) descreve, delimita e distingue os conceitos e também concorda com a concepção wüsteriana de unidade terminológica enquanto "símbolo convencional que representa uma noção definida num certo domínio fundador" (Wüster, citado por Desmet, 1990, p. 6). Como a definição aristotélica, a definição terminológica implica a demarcação de um limite. (p.94)

As terminologias seriam, desse modo, sistemas definicionais que refletem a organização estruturada e delimitada de domínios específicos. (p.94)

A definição terminológica é classificadora, hierarquizante, estruturante [...]. (p.94)

O significado é lingüístico; o conceito é terminológico. (p.94)

A definição terminológica busca definir o conceito, e não um significado, estabelecendo um jogo de conceito a conceito que determina as relações que os unem. (p.94)

A definição terminológica liga-se à definição aristotélica [...]. (p.94) 
Na ótica de Desmet (na linha da terminologia wüsteriana), o processo definicional parte do conceito para chegar ao termo, o que caracteriza um procedimento onomasiológico. As propriedades semânticas do conceito seriam como os predicados da lógica, e os conceitos inteiros, conjuntos coerentes de juízos sobre o objeto, refletindo suas características. (p.94)

Dahlberg distingue entre a definição real e a definição nominal, que se assemelham à definição terminológica e à definição lexicográfica discutidas por Desmet. A definição real procura delimitar a intensão de um conceito, e a definição nominal, fixar o sentido de uma palavra. A definição real relaciona-se com o conhecimento do objeto, apresentando "o conhecimento contido em determinado conceito" (Dahlberg, 1978). Já a definição nominal "procura fixar o uso de determinada palavra" (idem, ibidem). (p.94)

A diferença entre a definição terminológica e a definição lexicográfica remete, portanto, a perspectivas distintas de abordagem, muito embora elas não sejam isentas: a lexicografia parte do signo para chegar à determinação do conceito (procedimento semasiológico); a terminografia parte da noção (ou conceito) e pesquisa os termos que lhe correspondem (procedimento onomasiológico). (p.94)

Para a terminologia clássica, o termo é o produto de uma relação extralingüística que parte do objeto e é mediada pelo conceito. (p.94)

Um conceito tem, então, simplesmente, a significação de um termo. Não é possível, conseqüentemente, construir uma árvore nocional de seus conceitos para estruturar previamente um domínio" (Hermans, 1995).

A visão do autor é importante para compreender que a significação dos termos teóricos (ou científicos) é continuamente gerada pelo uso que os cientistas fazem dos termos. No processo de pesquisa podem ser gerados termos imprecisos, não exatamente por uma incapacidade de precisão, mas porque isso reflete a própria instabilidade e movimento das ciências.

"A estabilidade, nas ciências, equivale à estagnação" (idem, ibidem). Os termos na área científica refletem uma instabilidade que é próxima do equilíbrio entre determinação e indeterminação. Quando os conceitos científicos são muito determinados, eles deixam de funcionar como instrumentos de descoberta ou de explicação (idem, ibidem).

Contrariamente aos conceitos técnicos que têm objetos bem determinados, os conceitos teóricos são indeterminados. "A precisão é obtida sacrificando-se sua significação. E é graças a seu caráter metafórico e conotado que esses termos teóricos funcionam como elementos heurísticos e explicativos dentro da atividade científica" (idem, ibidem). (p.95)

As normas terminológicas não pressupõem a distinção entre termos técnicos e termos teóricos, tratando a todos como se fossem termos técnicos, o que se explica em grande parte pela origem da ISO e pelos princípios positivos à sua base. A terminologia mais contemporânea tem relativizado a distinção entre palavra e termo (Gaudin, 1995; Cabré, 2000) [...]. (p.95-96)

A terminologia clássica é mais onomasiológica, correspondendo, segundo Béjoint, a uma terminologia da denominação. A terminologia onomasiológica é "ancorada na referência”, colocando em jogo uma semântica extensional que tende a se "conformar ao princípio humboldiano (biunívoco) ... segundo o qual uma só forma deve corresponder a um só sentido e viceversa” (Béjoint, 1989). Béjoint bem observa que, na realidade, o trabalho terminológico combina os procedimentos onomasiológico e semasiológicos [...]. (p.96).

Para a ciência da informação, ou mais precisamente, para a lingüística documentária, as discussões sobre a definição colocam em relevo a necessidade de delinear procedimentos que observem as variedades das manifestações discursivas, sem pressupor que todos os discursos sigam o modelo clássico das ciências. (p.96)

e) Artigo 22: com base na Sociologia, Filosofia e Linguística aborda as influências do positivismo lógico na Teoria Geral da Terminologia (Wüster) e as novas vertentes dos estudos terminológicos. 
Como corpo sistemático de conceitos, a Terminologia nasceu na década de 30 com Eugène Wüster, a quem se atribui o papel de fundador da Teoria Geral da Terminologia, conhecida como TGT. O contexto histórico e intelectual da publicação de seus primeiros trabalhos mostra a proximidade do autor com Rudolf Carnap, filósofo do Círculo de Viena que se preocupa com a precisão na linguagem. Os objetivos de Carnap e de Wüster eram muito parecidos: "conseguir uma comunicação inequívoca e sem ambigüidade sobre os temas especializados" (Galinski \& Budin, 1998, p.15), a despeito de seus métodos diferentes. O ponto de partida de Wüster era a lógica conceptual clássica visando à criação de uma teoria e de uma metodologia da terminologia como contribuição à comunicação sem ambigüidade; o interesse de Carnap, como também de Popper e Wittgenstein, filósofos próximos à escola de Viena, eram as proposições lógicas e a estrutura proposicional das teorias (idem ibidem). (p.4)

Fiel à origem lógica, a TGT trata os conceitos como anteriores à sua expressão na linguagem e, por conseqüência, o léxico dos sistemas conceituais como nomenclatura ou taxionomia. Suas bases, pela proximidade aos filósofos citados, são os parâmetros modernos de ciência que incluem a busca da objetividade, da precisão e da não-ambigüidade e que se reportam aos princípios da filosofia analítica e do neopositivismo. Considerada uma vertente clássica da Terminologia, ela compartilha do ideal de uma linguagem unívoca, homogênea e universal, distinta da linguagem comum e concebe os conceitos como constructos mentais anteriores e independentes da linguagem. Deriva daí o privilégio que confere à normalização como meio de garantir uma comunicação unívoca. A ênfase na normalização é, também, tributária da natureza sistemática e do potencial classificador das linguagens (Sager, citado por Krieger, 2001). Ao privilegiar esses aspectos, a terminologia clássica o faz em detrimento da função primordial da linguagem que é ser instrumento de comunicação. (p.4)

As novas vertentes da Terminologia são socialmente orientadas. Dentre as principais se destacam a Teoria Comunicativa da Terminologia (Cabré, 1999), a Socioterminologia (Gaudin, 1993), a Teoria Sociocognitiva da Terminologia ou Socioontologia ou, ainda, teoria realista da terminologia (Temmermman, 2001) e a Terminologia cultural (Marcel Diki-Kidiri, 2000). Questionamentos à terminologia clássica também são feitos por lingüistas e psicólogos ligados à Semântica Cognitiva, como Dubois (2001) e Rastier (1995), dentre outros. (p.5)

A Teoria Comunicativa da Terminologia - TCT, proposta por Cabré, não nega a importância da teoria clássica e, embora não se coloque em oposição radical a ela, tende a ressaltar o papel da linguagem na caracterização das unidades terminológicas. A TCT propõe ver os termos como unidades lingüísticas, enfatizando a função da língua como instrumento de comunicação. A vertente se constitui na confluência entre a teoria do conhecimento, da comunicação e da linguagem. Ao questionar a autonomia da Terminologia em relação às teorias da linguagem, recupera a noção de termo como unidade de forma e conteúdo que, em determinadas condições discursivas, adquirem valor especializado (Cabré, 2000). (p.5)

Para Cabré, as unidades terminológicas fazem parte da linguagem natural, não considerando os termos como entidades autônomas que formam um léxico especializado diferenciado. Os termos são unidades denominativo-conceptuais que têm capacidade de referência desde que ativados em seu uso em contextos e situações determinados. (p.5)

A função dos termos para a TCT é dupla: representar e transferir o conhecimento especializado, em graus e modos distintos, como em situações diversas. As unidades terminológicas de caráter poliédrico desempenham funções cognitiva, social, comunicativa e lingüística. Enquanto unidades lingüísticas com valor especializado, a TCT admite a variação denominativa e conceitual. Diferentemente das propostas anteriores de Cabré (1993), a TCT atribui dimensão textual e discursiva à terminologia (Cabré, 1999). (p.5-6)

A Socioterminologia, por sua vez, prioriza o uso, realizando uma ruptura mais incisiva com a TGT. Enfatiza as práticas sociodiscursivas, particularmente profissionais, e seu papel na circulação social dos termos. Suas origens da Socioterminologia se reportam às críticas ao caráter prescritivo $e$ normatilizador da Terminologia feitas por Boulanger, em 1991, e reforçadas por Auger dois anos depois. Mas é com François Gaudin, na França, em 1993, que ela se firma como uma nova vertente, quando o autor enfatiza a necessidade de considerar as práticas lingüísticas e sociais efetivas (Faulstich, 2006). Criticando a influência do pensamento positivista na teoria de Wüster, Gaudin mostra que a relação entre o signo e a realidade não é direta, mas construída, ou mais exatamente, co-construída no quadro 
das interações verbais. A referência tem, portanto, um caráter social e, por essa razão, não é possível propor a biunivocidade entre conceito e termo. (p.6)

Para Gaudin, o fato de que as relações entre signo e realidade são relacionadas às situações sociais onde acontecem, justificaria a substituição do conceito de domínio pelo de 'episteme' (interpretável segundo a abordagem foucaultiana), mais adequado para descrever a realidade do trabalho científico e das práticas lingüísticas que o sustentam. (p.6)

Para Gaudin, a Socioterminologia considera as metáforas e os contextos históricos de uso das palavras, o que implica o questionamento da monossemia dos termos (que tem por corolário a reabilitação da polissemia) e da variação como uma "perturbação da unidade lingüística", na expressão de Wüster (Wüster, 1998, p.150). (p.6)

Mais recente, a Teoria Sociocognitiva da Terminologia põe em destaque o papel dos modelos cognitivos procurando mostrar as relações entre os processos de categorização e a linguagem. A vertente é baseada na semântica cognitiva e questiona a centralidade da padronização em detrimento de uma descrição realista dos significados dos termos tal como aparecem nos textos. (p.6)

Para Temmermman (2001), responsável pela proposta, a definição de conceito da terminologia tradicional, como unidade de pensamento constituída por abstração de propriedades, é muito restritiva, já que poucos conceitos existem de forma objetiva. O mundo é melhor compreendido no marco dos modelos cognitivos nos quais se relacionam diferentes unidades de compreensão ou entendimento estruturadas de forma prototípica. Essa é a razão pela qual propõe substituir a noção de conceito por unidade de compreensão (entendimento) observando que grande parte das unidades ditas conceituais têm uma estrutura prototípica e que podem, dessa forma, denominar categorias (Temmermann, 2001). A base para a delimitação do conteúdo é, segundo sua perspectiva, o texto no qual está inserido o termo, do que decorre que o conceito não é universal, nem imutável, "mas a expressão de um conjunto de elementos de natureza lingüística que se consubstanciam num texto que possui não apenas uma dimensão lingüística, mas também pragmática, discursiva e comunicativa" (Barros, 2006, p.23). (p.6-7)

No Brasil, as proposições teórico-metodológicas da TGT que forneceram as primeiras coordenadas do saber e das práticas em Terminologia, são, agora, submetidas à revisão, sugerindo-se a valorização dos aspectos lingüísticos e comunicacionais dos termos técnico-científicos. Como conseqüência, o léxico especializado passa a ser compreendido na sua dimensão de componente natural das línguas naturais, não imunes, portanto, aos efeitos devidos ao funcionamento da língua (Krieger, M.G. \& Bevilacqua, C.R., 2005), o que já indica a possibilidade de contribuir ao enfrentamento de um conceito contemporâneo de informação. (p.7-8)

As interfaces entre Terminologia e Lingüística Documentária, no Brasil, tiveram início a partir da proposta clássica, através das normas terminológicas internacionais (ISO 704-2000 e ISO 1087/1-2000, entre outras) e dos textos teóricos fundamentais. (p.8)

[...] o trabalho documentário de organização da informação para a recuperação não alcança seus objetivos se ficar restrito ao uso das referências da terminologia clássica, fato que ocorre, principalmente, frente a universos que não constituem formalmente um domínio claramente delimitado ou que se encontram em transformação, caracterizando-se por inúmeras relações interdisciplinares. (p.8)

A Terminologia clássica não responde, portanto, às necessidades de tratar a heterogeneidade, a diversidade e a multiplicidade dos pontos de vista da produção, do uso e do consumo informacional. (p.8)

f) Artigo 23: Com foco na construção de informação documentária, o artigo discute o conceito sob perspectiva lingüística e semiótica.

[...] conceito: unidade de conhecimento criada pela combinação de características únicas;[...]. (p.128)

recorte de conteúdo: segundo Benjamim Whorf, cada língua "recorta a realidade de um modo particular", segundo sua cultura. Essa afirmação complementa a proposta anterior de Saussure, segundo a qual a língua é forma, não substância. (p.129) 
continuum da realidade: expressão utilizada por Eco para se referir ao que Hjelmslev nomeou sentido, fator comum entre as línguas, pensamento provisoriamente apresentado como massa amorfa, grandeza não analisada. Hjelmslev postulou a solidariedade entre as funções de expressão e conteúdo, afirmando que é impossível existir uma sem a outra, o que implica dizer que não há pensamento sem linguagem. (p.129)

A terminologia trabalha a partir do conceito. O conceito, como já vimos, é uma unidade de conhecimento formada por uma combinação de características. A formação do conceito é um processo de abstração que tem como base a seleção de propriedades (características) de um conjunto de um ou mais objetos. $O$ conceito, conseqüentemente, não tem vida independente, mas é o resultado de uma proposição feita dentro de um domínio do saber. Cada conceito é determinado pela posição que ocupa no conjunto estruturado de conceitos, denominado sistema conceitual.

A unidade básica da terminologia é o termo, designação verbal do conceito dentro de um domínio específico. A designação é uma representação do conceito por um signo que o denota (um símbolo, um nome ou um termo). Para elaborar um sistema de conceitos, enquanto conjunto estruturado segundo as relações que os unem, o trabalho terminológico parte de definições. A definição é a representação de um conceito por um enunciado descritivo que permite diferenciá-lo de conceitos relacionados dentro de um domínio de especialidade. (p.135)

Os processos de tratamento e recuperação de informações apresentam características similares às que ocorrem no processo de conhecimento em geral. Não é sem razão que as metodologias de organização da informação fazem uso de referenciais da lógica, da semiótica, da lingüística, da semântica, da pragmática e das ciências cognitivas. Procuram-se, a partir desses referenciais, operacionalizar com maior rigor os procedimentos de identificação e registro das conjunções (superordenação), das disjunções (subordinação), das associações não-lineares e das equivalências entre os termos, à semelhança do que ocorre, grande parte das vezes de forma inconsciente, em qualquer processo de conhecimento. (p.138)

g) Artigo 24: discute as linguagens documentárias. Relaciona a Terminologia, a Lingüística e a Semiótica aos processos documentários, apresentando o conceito com base na terminologia clássica.

recorte de conteúdo: Segundo Benjamim Whorf, cada língua "recorta a realidade de um modo particular", segundo sua cultura. Essa afirmação complementa a proposta anterior de Saussure, segundo a qual a língua é forma, não substância. (p.3)

A Terminologia trabalha a partir do conceito. Um conceito, como já vimos, é uma unidade de conhecimento formada por uma combinação de características. A formação de um conceito é um processo de abstração que tem como base a seleção de propriedades (características) de um conjunto de um ou mais objetos. O conceito, conseqüentemente, não tem vida independente, mas é o resultado de uma proposição feita dentro de um domínio do saber. Cada conceito é determinado pela posição que ocupa no conjunto estruturado de conceitos, denominado sistema conceitual. (p.9)

A unidade básica da Terminologia é o termo, designação verbal de um conceito dentro de um domínio específico. Uma designação é uma representação de um conceito por um signo que o denota (um símbolo, um nome ou um termo). Para elaborar um sistema de conceitos, enquanto conjunto estruturado de acordo com as relações que os unem, o trabalho terminológico parte de definições. A definição é a representação de um conceito por um enunciado descritivo que permite diferenciá-lo de conceitos relacionados dentro de um domínio de especialidade. (p.9)

As definições podem ser intensionais ou extensionais. A definição intensional (ou por compreensão) descreve a intensão do conceito indicando o conceito superordenado e as características distintivas do conceito em foco. Dito de outro modo, faz menção ao conceito genérico mais próximo, já definido ou supostamente conhecido, e às características distintivas que delimitam o conceito a ser definido. Já a definição extensional (ou definição por extensão) descreve o conceito enumerando todos os conceitos subordinados segundo um critério de subdivisão. (p.9)

Lembre-se que a palavra é uma unidade do léxico de uma língua; a representação do léxico constitui o dicionário da língua. (p.10). 
Já o termo é uma unidade da terminologia. Seu significado é fixado no interior de um domínio, ou seja, corresponde à palavra contextualizada no uso (no discurso) de um determinado campo do saber (LE GUERN, 1989). O significado de um termo é delimitado pelas relações que estabelece com os outros termos do mesmo domínio (fixado no processo definicional, para facilitar a comunicação). (p.10)

O uso do termo (e de mapas conceituais de domínios) permite à Documentação transformar uma atividade anteriormente empírica, de categorização, num trabalho teórica e metodologicamente sedimentado em referências concretas dos domínios de especialidade. O uso da Terminologia teórica e das terminologias concretas cria condições, conseqüentemente, para formular propostas de organização das linguagens documentárias à medida que provê fundamentos para a seleção e estruturação dos termos. (p.10)

[...] as metodologias de organização da informação fazem uso de referenciais da Lógica, da Semiótica, da Lingüística, da Semântica, da Pragmática e das Ciências Cognitivas. Procura-se, a partir desses referenciais, operacionalizar com maior rigor os procedimentos de identificar e registrar as conjunções (superordenação), disjunções (subordinação), associações não-lineares, equivalências entre os termos, à semelhança do que ocorre, grande parte das vezes de forma inconsciente, em qualquer processo de conhecimento. (p.12)

h) Artigo 29: com foco no conceito de ciberespaço, parte da indagação sobre a criação de conceitos na filosofia e na ciência. Aborda o conceito com base em Deleuze e Guattari.

O que é um conceito? É a ciência que o cria ou a Filosofia? A Arte tem alguma participação na criação de conceitos? (p.1)

Para Deleuze e Guattari (1997a, p.163) cabe à Filosofia criar os conceitos e não à ciência, pois a diferença entre as duas reside no "... pressuposto respectivo do conceito e da função: aqui um plano de imanência [ou consistência], lá um plano de referência [ou coordenação]." Já a Arte consiste em situarse no plano da composição. Portanto, a Filosofia cria os conceitos, independentemente do seu plano de referência ou de uma figura. A imanência dos mesmos permite o sobrevôo nos acontecimentos, um devir uma vez que "O conceito é o contorno, a configuração, a constelação de um acontecimento por vir. "Os conceitos, neste sentido, pertencem de pleno direito à filosofia, porque é ela que os cria, e não cessa de criá-los." (p. 46). (p.2)

À ciência cabe buscar a referência do conceito, ou melhor, sua função é extensiva, ao passo que a Filosofia é intensiva justamente porque cria os conceitos. Ora, no plano de referência está a figura, o objeto e a explicação desses objetos. Assim ocorre que a ciência é discursiva e suas proposições não devem ser confundidas, segundo os autores supracitados, com os conceitos, mas antes, são explicações das funções acerca dos conceitos ou com os estados de coisas no qual se encarnam. (p.2-3)

A Filosofia pensa por conceitos, a ciência por figuras, que são essencialmente projetivas, paradigmáticas, hierárquicas e referenciais, em contrapartida, os conceitos são conectivos, sintagmáticos, vicinais e consistentes. Eis que apesar dessa divisão de trabalho entre o cientista, o filósofo e o artista, uma matriz comum pode suscitar entre eles relações de conexão (Deleuze e Guattari,

1997a). (p.3)

i) Artigo 30: tem como objeto principal de discussão a abordagem filosófica da representação. Num segundo momento, o conceito é analisado na perspectiva filosófica e da linguagem, contrastando as perspectivas neopositivista, funcionalista e marxista.

A comunicação da ciência para ser entendida e conhecida pelo maior número possível de pessoas se faz através do conteúdo objetivo do conhecimento, isto é, de conceitos e das condições sociais do meio em 
que são produzidos. Os conceitos se constituem em abstrações que são elementos do pensamento e produtos teóricos, aproximando-se da realidade. Os conceitos pouco abstratos são descrições que constituem o conhecimento científico. (p.6)

A influência do neopositivismo, nascido neste final do século, se faz presente na construção das representações. Ele pertence ao momento semiótico, onde o conhecer transfere-se para o representar. (p.6)

A filosofia clássica ou metafísica é rejeitada por não ser verificável. A filosofia analítica ou neopositivismo verifica o significado dos conceitos. Os conceitos abstratos além de representar o objeto contém a razão de ser dos objetos representados. Os fenômenos não são explicados mas descritos na sua regularidade. A ciência torna-se uma descrição do que nela se passa.

O rigor sintático e semântico da linguagem científica é exigido pelos neopositivistas, denunciando assim uma incapacidade de apreender a essência da realidade.

Sob a influência da mecânica, a ciência do movimento, a fenomenologia passa a elaborar conceitos que não explicam "por que" e sim "como" as coisas acontecem. (p.6)

Para Marx as representações, que são abstrações, possuem determinações que se expressam através de conceitos. As determinações não são aleatórias. Há relações necessárias e obrigatórias entre a natureza e o conhecimento e outros elementos da realidade. A ciência é puramente uma relação social e é este tipo de relação o grande elemento construtor da sociedade. As relações sociais são organizadas pelas determinações. (p.7)

Para Althusser, "o discurso científico utiliza palavras da linguagem cotidiana ... A diferença é que na linguagem teórica as palavras funcionam como conceitos teóricos. ...o sentido das palavras não é fixado pelo seu uso corrente, mas pelas relações existentes entre os conceitos teóricos no interior de seu sistema." (Escobar, 1975, p. 62). (p.7)

Na descrição do conteúdo de um livro ou documento são utilizadas palavras que condensam o assunto e o identificam com o objetivo de facilitar a recuperação e a transferência do conhecimento. Estas palavras são representações de representações (textos, conceitos) e consequentemente guias parciais e imperfeitos. (p.9)

A classificação de Dewey sofreu influência do iluminismo e do positivismo e não poderia ser diferente pois "o pensamento científico não se desenvolve num vazio cultural, mas no interior de um quadro de pensamento, de um contexto de idéias, de princípios fundamentais e de evidencias axiomáticas pertencentes a um domínio de ordem extracientífica." (Japiassu, 1975, p. 24).

O positivismo pregava a transformação da filosofia em ciência baseado na capacidade humana de perceber a estrutura dos fenômenos, reforçando a hegemonia das tabelas classificatórias que, além de encarnarem a eternidade, neutralidade e universalidade do saber, utilizavam números e sinais gráficos aproximando-se da matemática para legitimá-las. (p.9)

j) Artigo 38: com o objetivo de descrever as teorias que fundamentam a construção de linguagens documentárias, aborda o conceito a partir da Teoria do conceito (Dahlberg) e das normas (ISO 704 e 1087). Discute a Teoria Geral da Terminologia, a Teoria Comunicativa da Terminologia, a Socioterminologia e o funcionalismo lingüístico.

Termos, conceitos e características são elementos comuns em toda linguagem documentária. Para Dahlberg (1978), filósofa alemã criadora da Teoria do Conceito, a soma total dos enunciados verdadeiros sobre um objeto forma o conceito desse objeto.

Segundo a autora, os enunciados são compostos por elementos do conceito, esses elementos são as características do conceito, em outras palavras, características são os atributos predicáveis do objeto. (p.99)

[...] os termos são considerados pelas ISOs 704 (2000) e 1087-1 (2000) como sendo a unidade mínima da terminologia. Para Lara (2004a) o termo é uma designação que corresponde a um conceito em uma 
linguagem de especialidade. O conceito é, para o Manual de Elaboração de Tesauros Monolíngües criado por Hagar Espanha Gomes em 1990, um construto mental que representa um objeto individual material ou imaterial. Pode-se afirmar, pautado na Teoria Comunicativa da Terminologia (TCT), que conceito é a representação mental de um objeto, e que, somado a uma unidade lexical que o denomina, forma o "termo". Os conceitos sempre estarão relacionados entre si, e o que determinará essas relações serão as características inerentes aos conceitos. (p.99)

Em estudo mais aprofundado, Lima (2004) apresenta uma distinção entre termos e descritores, pois não raramente se encontra na literatura um uso indiscriminado desses dois signos que segunda Lima se distinguem em vários aspectos. Embasada por Lariviere, Lima (2004) pontua o seguinte: os termos pertencem exclusivamente às linguagens de especialidade, ao passo que os descritores podem pertencer às linguagens de especialidade e à linguagem comum; os termos são geralmente extraídos dos documentos, ao passo que os descritores geralmente são signos conhecidos dos usuários e em hipótese alguma são criados; os termos remetem a um objeto da realidade, enquanto que os descritores remetem a documentos que tratam dessa realidade; o termo se refere a uma só realidade (monorreferencial), enquanto o descritor é escolhido (preferencialmente) entre outros descritores para representar uma determinada realidade. Lima (2004) aponta também algumas semelhanças entre termos e descritores, a saber: ambos são unidades significantes que representam um conceito dentro de um domínio de conhecimento; e ambos são unidades da linguagem natural e não códigos artificiais. (p.100)

[...] a definição postulada por Cabré (1999), que enfatiza ser o 'conceito' um elemento pertencente ao 'termo', pois o termo é composto por um conceito e uma unidade lexical que o denomina. (p.100)

A Teoria do Conceito de Ingetraut Dahlberg, que analisa o conceito como a soma total dos enunciados verdadeiros de um objeto, pontuando informações a respeito de suas características, relações, categorias $e$ definições, é a teoria que vem freqüentemente fornecendo subsídios teóricos aos estudos de representação do conhecimento na área da Ciência da Informação. (p.101)

Dentre as teorias da Terminologia que ancoram os estudos mais recentes de organização e representação do conhecimento, merecem destaque a Teoria Geral da Terminologia (TGT) de Eugen Wüster, Teoria da Socioterminologia de François Gaudin e a Teoria Comunicativa da Terminologia (TCT) de Maria Teresa Cabré. A TGT, dotada de uma perspectiva prescritiva e normativa, é responsável pelo fornecimento dos primeiros supostos de trabalhos terminológicos. A Socioterminologia dotada de uma perspectiva descritiva, dando ênfase ao uso social da língua, possibilita maior variação e flexibilidade lexical e conceitual, o que proporciona uma maior aproximação entre mecanismos de informação e usuários. A TCT, embasada pela Socioterminologia, fundamenta-se em aspectos comunicativos das línguas naturais. Paralelo a isso, a Teoria da Gramática Funcional de Simon Dik, também vêm sendo aplicada no campo da Ciência da Informação, postulando fundamentos preciosos aos estudos de linguagens documentárias. (p.102)

Nota-se na literatura que um número considerável de estudos relacionados à linguagem documentária são embasados teoricamente pela Teoria do Conceito de Dahlberg e pela Teoria Geral da Terminologia de Wüester. Segundo Tristão; Fachin; Alarcon (2004), para a compreensão do conceito e de suas relações é imprescindível adotar princípios da Teoria do Conceito, pois se trata de um método indicado para a fixação do conteúdo do conceito, conseqüentemente, determinante para o posicionamento desse dentro de um sistema de conceitos. Esse preceito converge com afirmações proferidas anteriormente e posteriormente por Moreira (2003), Gomes e Campos (2004), Moreira; Alvarenga; Oliveira (2004), Pereira e Bufrem (2005) et al., Pereira e Bufrem (2005), além de utilizarem as teorias do Conceito e da Terminologia, lançam mão da Teoria da Classificação Faceta de Ranganathan para analisarem princípios e métodos de organização e representação de conceitos para as linguagens documentárias. (p.104)

Na esfera da Terminologia, ficam evidentes duas vertentes teóricas distintas. A primeira, liderada pelos postulados da TGT, desenvolve o raciocínio sob uma perspectiva formal e prescritiva, e, a segunda, liderada pela Socioterminologia e pela TCT, postula seus fundamentos sob a abordagem funcionalista do uso lingüístico. (p.110)

k) Artigo 40: tem seu foco principal nos aspectos teóricos da pesquisa em Ciência da Informação. Analisa o conceito e sua formação em relação direta com a linguagem e a semiótica. 
O conceito, define-se como um conjunto de propriedades - traços ou características -que não só representam os estados de mundo, discriminando-os, mas também permitem elaborar redes conceituais segundo o traço considerado. (7-8)

É justamente esta possibilidade de estabelecimento de inúmeras relações entre os traços que leva um mesmo conceito a integrar diferentes contextos, expressando variações de significado. Portanto, tão importante quanto entender nocionalmente o conceito é entendê-lo como elemento de um sistema de conceitos, ou seja, unidade de uma rede de traços. Por sua vez, os traços ou características do conceito estabelecem simultaneamente diferenças e semelhanças entre os conceitos: no seu conjunto os traços que compõem um conceito o identificam, discriminando-o, mas à medida que cada uma das características é selecionada são estabelecidas, a cada vez e sucessivamente, relações entre diferentes conceitos, de acordo com contextos específicos de sentido. (p.8)

O conceito, definido como feixe de traços, é operacionalizado através da combinatória entre esses mesmos traços, propiciando que a cada atualização efeitos de sentido imponham-se de acordo com diversos contextos em jogo. Do mesmo modo, a informação e o conhecimento submetem-se a diferentes ordens de acordo com a temática selecionada e adotada. É justamente o fato de o conceito propiciar a composição de infinitos arranjos integrados a infinitos contextos que responde parcialmente pela capacidade da linguagem de enfrentar a imprevisibilidade do mundo, interpretando-o continuamente na mudança. (p.8)

[...] para formar conceitos a partir das ocorrências dos termos, é necessário comparar, refletir e abstrair. (p.11)

O conceito apresenta-se sinteticamente como um nome, na forma substantivada. À forma significante atribui-se a denominação termo. O conteúdo do termo denomina-se conceito, que se apresenta como um conjunto de traços elou propriedades. Atribuir um conceito a um termo depende da formulação de juízos. (p.11)

[...] o juízo apresenta-se como um ato proposicional que atribui qualidades a um termo. Aqui, no entanto, não nos interessa estudar a relação entre as proposições, mas estabelecer a funcionalidade do conceito na produção de linguagem e por consegüinte na geração do conhecimento. (p.12)

1) Artigo 41: o foco do artigo é o conceito de ciberespaço. Apresenta uma análise do conceito na perspectiva lingüística e da Teoria Comunicativa da Terminologia, de

Cabré.

Foi somente em 1931, com a obra do austríaco Eugene Wüster, que é proposta a Terminologia como disciplina científica, quando se afirma a diferença entre o conceito e o significado, a qual será motivo de críticas posteriores, conforme Krieger e Maciel (2001). À época, no entanto, o impacto da disciplina restringiu-se à Rússia. Credita-se à influência de Wüster a criação do Comitê Técnico 37 (TC 37) da ISA (International Standardization Association), fundada em 1926 e precursora da ISO (International Organization for Standardization), cujo objetivo era o de unificar métodos de trabalho e terminologias (PICHT apud CABRÉ, 1993, p.22). (p.5)

Para desenvolver o pensamento conceitual, devemos operar com conceitos e juízos formais. Genericamente, para formar conceitos a partir das ocorrências dos termos, é necessário comparar, refletir e abstrair. Essas três operações básicas do intelecto constituem as condições essenciais e universais para a produção de qualquer conceito. O conceito apresenta-se sinteticamente como um nome, na forma substantivada. À forma significante atribui-se a denominação termo. $O$ conteúdo do termo denomina-se conceito, que se apresenta como um conjunto de traços elou propriedades. Atribuir um conceito a um termo depende da formulação de juízos. O juízo, por sua vez, é um julgamento que relaciona uma qualidade a um termo (A cadeira é de metal, por exemplo). Como procede através de conceitos, o juízo responde pelo conhecimento não imediato mas mediato de um objeto da realidade. $O$ conceito tanto pode se apresentar como um feixe de características ou como a própria característica. Por exemplo, em "O homem é mortal" o juízo associa a qualidade mortal ao conceito homem, em "Esta pessoa é um homem" o juízo associa a qualidade sexo masculino ao conceito pessoa (ser humano). (TÁLAMO, 2004). (p.7) 
O conceito permite agrupar os objetos, articulando-os segundo relações de semelhança-diferença. "A esse processo de generalização (categorização) segue-se o processo de classificação que se traduz em categorias cognitivas, ou conceitos mentais, que armazenamos em nosso cérebro" (BIDERMAN. 2001, p.156). (p.7)

Na metade do século XX, com a crescente especialização do conhecimento, começa a ganhar força a idéia do conceito como núcleo organizador das linguagens documentárias. Não se trata mais de emprender uma ordem física dos livros mas uma ordem dos conceitos ou dos significados para a representação da informação. Na década de 50, impõe-se a idéia de descritor associada a de conceito. Como unidade preferencial do tesauro documentário, o descritor define-se como forma significante ou de expressão - palavra ou grupo de palavras-chave ou significativas-representativas dos conceitos e idéias. Fica assim definitivamente determinado o conceito e suas relações como o vértice para a elaboração de linguagens documentárias. É, portanto, a noção de conceito que permite relacionar thesaurus lingüístico e tesauro documentário. (p.16)

A solução para os sistemas de recuperação da informação está na representação dos conceitos e suas relações, expressos nos documentos, em uma forma de linguagem padronizada, obtida pelo controle de sinônimos e uma estrutura sintática mais simplificada que a da linguagem natural. (p.16)

m) Artigo 18: o objetivo principal do artigo é discutir a idéia de que a formulação de conceitos de uma área está diretamente relacionada com suas questões epistemológicas.

[...] o objetivo do presente artigo é refletir sobre a construção conceitual no campo da ciência da informação. Esta reflexão tem duas justificativas básicas: a) a formulação dos conceitos possibilita a ruptura epistemológica com o senso comum, ou seja, é um dos caminhos possíveis para a construção de uma ciência; $b$ ) os conceitos são os materiais empregados na elaboração de modelos científicos que, por sua vez, permitem a observação, descrição e interpretação dos objetos teóricos e empíricos de um campo do conhecimento, assim como os fenômenos presentes, passados e futuros a eles relacionados. (p.46)

Já Rubem Alves esclarece:

"Um modelo é um artefato construído pelo cientista. Quando falamos em artefatos, pensamos em coisas fabricadas com o auxílio de materiais sólidos, como relógios, máquinas de moer carne, cortadores de unha, satélites artificiais. Todos são artefatos produzidos pela arte dos homens. (...) Para se construir um modelo, fazemos uso não de materiais sólidos, mas de conceitos."

Guiando-nos pelos autores citados anteriormente, podemos afirmar que, para a ciência da informação atingir um padrão de cientificidade, seus pesquisadores e profissionais precisam estar atentos à formulação de conceitos. (p.46)

Ducrot define conceitos metodológicos e conceitos descritivos. Para o autor, enquanto aqueles englobam conceitos mais gerais, estes englobam mais particulares. Parafraseando Ducrot, poderíamos dizer que os conceitos metodológicos relacionam-se com a teoria, enquanto os conceitos descritivos são mais voltados à operacionalidade da teoria, devendo haver para o conceito descritivo pelo menos um conceito metodológico e vice-versa. (p.50)

No percurso histórico da biblioteconomia e da documentação, sempre conceitos e denominações provenientes de outras ciências ou disciplinas foram importados elou adaptados [...] Nesse sentido, importaram-se conceitos e denominações de algumas teorias da administração, da lingüística, da lógica, da comunicação e de outras áreas. Porém, visando-se a um uso imediato desses conceitos e denominações, não houve compreensão/problematização dos conceitos metodológicos e conceitos descritivos e um questionamento sobre as implicações do uso de conceitos e denominações provenientes de diferentes áreas do conhecimento. (p.51)

Tais importações levaram a biblioteconomia e a documentação a:

a) elaboração de conceitos descritivos compatíveis com os conceitos metodológicos de origem, mas que, com o passar do tempo, foram se tornando desatualizados em relação ao estado-da-arte tanto da administração, quanto da lingüística;

b) elaboração de conceitos descritivos incompativeis com os conceitos metodológicos de origem;

c) em decorrência dos itens a e b, nos momentos em que a biblioteconomia e documentação tentaram atualizar os conceitos descritivos que utilizam, não obtiveram êxito devido à ausência de conceitos metodológicos internos à área. (p.51) 
As observações realizadas indicam que a área se voltou para questões circunstanciais e procurou, na importação de conceitos e denominações provenientes de outras ciências, uma justificativa "científica" para a atividade prática, adotando, muitas vezes, uma postura eclética. (p.51)

O conceito de ecletismo por nós adotado segue a definição estabelecida por Oliveira Filho. Segundo ele: "Ecletismo é o uso de conceitos fora dos seus respectivos esquemas conceituais e sistemas teóricos, alterando os seus significados. A ocorrência do termo, sem definição que reduzisse ou eliminasse a sua ambigüidade, não permitiria saber a qual de vários conceitos possíveis está associado. Inadvertidamente, muitas vezes, utiliza-se o sinal que expressa o conceito, mas não o próprio conceito. $O$ discurso torna-se vazio ou obscuro sem que o cientista social perceba que a sua linguagem pode dificultar a comunicação. Se tal ocorrência é grave em nível da teoria, será gravíssima em nível metateórico ou meta-sociológico. Neste caso, os conceitos metodológicos desprovidos de suas características limitar-se-ão a nomeações e classificações rituais de postura sem qualquer influência nas estratégias de investigação, o que é comum em textos produzidos por autores desprovidos de treinamento metateórico.

A biblioteconomia e a documentação não propõem conceitos. Estando voltadas para o objetivo de analisar, organizar e disseminar a informação, importam denominações e conceitos de outras áreas sem estabelecer um debate ou uma problematização sobre a que conceito se refere a denominação importada ou a qual denominação se refere o conceito importado. Com isso, nesta área, a ruptura com o senso comum parece ser muito frágil, ou quase inexistente. (p.51)

n) Artigo 20: segue a mesma linha do artigo 18, porém, seu objeto é o conceito de Ciência da Informação. O pano de fundo da análise é a construção de conceitos na área.

[...] a interdisciplinaridade do domínio, obtida quase que unicamente através da assimilação de conceitos de outras áreas, caracteriza-se como eclética. (p.4)

O ecletismo define-se como o "uso de conceitos fora de seus respectivos esquemas conceituais e sistemas teóricos, alterando os seus significados... Inadvertidamente, muitas vezes, utiliza-se o sinal que expressa o conceito, mas não o próprio conceito. O discurso torna-se vazio ou obscuro sem que o cientista social perceba que a sua linguagem pode dificultar a comunicação... Os conceitos metodológicos desprovidos de suas características limitar-se-ão a nomeações e classificações rituais de postura sem qualquer influência nas estratégias de investigação. Termos vazios de significado (sem conceitos) não podem funcionar como instrumentos de reconstrução teórica ou metodológica" (Oliveira Filho 1995, p.263). A importação de conceitos de outras áreas é apontada por Wersig (1993, p.235-236) como um problema teórico a ser enfrentado, e o autor cita exemplos de conceitos que, a seu ver, deveriam ser redefinidos ou adequados em sua abrangência: "sistema", "comunicação", "organização", "evolução" ou "interface". (p.5)

Quando não consolidados, muitas vezes, os conceitos, pela própria dinâmica da comunicação, passam a ter uma trajetória errática, principalmente em áreas, como é o caso da Ciência da Informação tomada aqui como objeto de estudo, que tardiamente pleiteiam para si o estatuto científico e se impõem de maneira heteróclita. Dito de um outro modo, na ausência de um assentamento conceitual ou na presença de ambivalências semânticas, que poderiam supostamente estabelecer condições de criação, tem-se um impasse ou retardamento teórico, que compromete a área como um todo. (p.6)

Como os conceitos atribuídos aos termos não resultam de convenções arbitrárias ou de preferências individuais, mas de relações entre suas características constitutivas, passíveis de serem objetivadas e confirmadas, o reconhecimento de uma denominação e de seu conceito é tarefa que exige análise da pertinência dessas características ou traços em relação ao domínio considerado. (p.6)

o) Artigo 36: Discussão dos conceitos na Ciência da Informação, fundamentada no método histórico de Koselleck. O artigo parte de um campo teórico-metodológico (história dos conceitos) para analisar aspectos epistemológicos da área a partir do conceito de Ciência da Informação. O foco principal são os conceitos científicos, de 
cunho disciplinar-acadêmico. Trabalha com a perspectiva hermenêutica e fenomenológica. Cita filósofos como Heidegger e Gadamer.

[...] propomos a adoção de uma abordagem teórico-metodológica que pode contribuir para as questões de ordem conceitual na ciência da informação. A partir de uma perspectiva historiográfica criada pelo historiador alemão Reinhart Koselleck - a história dos conceitos - buscamos edificar possíveis diálogos entre a referida abordagem e a ciência da informação. (p.18)

Visamos, todavia, apresentar uma perspectiva teórico-metodológica do campo historiográfico - a história dos conceitos - que poderá contribuir para as reflexões disciplinares e científicas da ciência da informação no tocante às discussões conceituais que permeiam aqueles interesses de estudo no campo epistemológico [...]. (p.25)

Se pensarmos o conceito genericamente, ele seria o símbolo representativo da abstração produzida mediante o intelecto na expressão da idéia de uma coisa ou fenômeno observável. (p.25)

[...] se apreendermos o conceito dentro da lógica e da razão científica, ele seria a delimitação necessária que a linguagem científica se apóia para a representação da realidade mediante uma simbologia criada pelo primado da exatidão, da sensibilidade e da consensualidade (intersubjetiva), na busca pela representação dos fenômenos da realidade. (p.25)

O conceito científico também é apreendido como um construto, por possuir um significado construído intencionalmente à luz de um marco teórico. (p.25-26)

Os primórdios da acepção de conceito científico podem ser traçados a partir da criação da própria ciência quando esta buscou autonomia da filosofia. (p.26)

[...] o conceito científico tem como característica principal a prioridade do método (perspectiva científica) sobre a ontologia (perspectiva filosófica que se dedica ao estudo do ser). (p.26)

A divergência em relação à premissa ontológica pode ser observada na geometria e na aritmética, pois tais disciplinas constituíram os primeiros saberes positivos [...] Nessa perspectiva, segundo dissertou Vuillemin (1987, p.117), o que passou a valer não foi o "[...] estatuto ontológico, mas o estatuto metodológico do conceito” [...]. (p.26)

[...] são quatro as condições necessárias para tornar científico um conceito, a saber: 1) controle equacional de um elemento presente em um dado sistema natural, na constituição de uma lei, por exemplo; 2) constituição de uma linguagem técnica e não simplesmente comum; 3) evidência de conceitos implícitos (complexos) em lugar daqueles explícitos (simples) originados do modelo ontológico lingüístico que não demonstravam o conjunto de axiomas que os comporiam; 4) mensurabilidade dos conceitos científicos, assim como das leis que os interligam. (p.26)

[...] o traço distintivo dos conceitos científicos é a possibilidade de se refutar a hipótese de que fazem parte [...] Vuillemin (1987, p.119) pontuou que "[...] a refutação não faz mais do que traçar os limites de aproximação, no interior dos quais é ainda possível utilizar os conceitos como meios de previsão e de descrição simplificada da natureza”. (p.26)

[...] o emprego do método foi o ponto de partida que propiciou às ciências naturais definirem o que seria o conceito científico na busca pela positividade do objeto para que este pudesse ser controlado, mensurado, delimitado, etc. (p.26)

[...] a abertura da instrumentalidade do método [...] possibilitou o surgimento das ciências humanas por meio [...] de uma nova roupagem dos princípios mecânicos da Física, direcionando-os ao social. (p.26)

[...] as propriedades de um conceito científico poderão explicar a ciência que a ele se relaciona. Através do estudo dessas propriedades, podemos identificar como ocorreu, por exemplo, o desenvolvimento disciplinar de uma ciência, quais foram os pressupostos orientadores, quais foram os avanços e retrocessos que o emprego de um conceito proporcionou em determinado período histórico, em determinada teoria, em determinada escola científica, etc. (p.27)

Para o estudo dos conceitos dessa natureza, encontramos no trabalho do historiador alemão Reinhart Koselleck (1923-2006) um potencial teórico-metodológico para pensarmos as questões conceituais no campo da ciência da informação. (p.27)

Para a construção do seu quadro teórico-metodológico, Koselleck encontrou subsídio teórico principalmente nas obras de Emmanuel Kant (1724-1804) e de Carl Schmitt (1888-1985) (CASTELO 
BRANCO, 2006) (5) e na acepção hermenêutica dos filósofos Martin Heidegger (1889-1976) e de HansGeorg Gadamer (1900-2002) relativamente às respectivas apreensões acerca da posição fenomenológica entre sujeito/objeto e de suas principais categorias de análise. (PEREIRA, 2004). (p.27)

[...] Koselleck (2006) parte da sua própria perspectiva de análise em que objetiva, de modo geral, unir a abordagem filosófico-hermenêutica ao campo historiográfico para o desenvolvimento de sua história dos conceitos. [...] Koselleck une os enfoques hermenêuticos ontológico (filosófico) e analítico-causal (científico) que se mesclam sob um prisma historiográfico. (p.28)

[...] Koselleck (2006) propôs uma história dos conceitos que considerasse as experiências históricas e as ações humanas representadas nos conceitos. (p.29)

[...] a história dos conceitos é um método especializado de crítica das fontes, atento ao emprego das noções políticas e sociais essenciais expressas nos documentos da época estudada. (p.29)

O escopo de investigação de Koselleck (2006) reside nas questões relativas à semântica política dos conceitos, ou seja, no estudo dos momentos de duração, alteração e futuridade que uma situação política concreta se expressa linguisticamente. (p.29)

[...] do aspecto polissêmico do conceito poderá emergir a tradução de significados do passado para os dias atuais $[\ldots]$ (p.29)

[...] a ciência da informação ainda carece de estudos histórico-conceituais mais afinados que evidenciem as particularidades destes quadros teóricos. (p.30)

Desde uma perspectiva epistemológica, partimos da premissa de que os estudos de Koselleck (1992; 2006) podem contribuir para a ciência da informação [...]. (p.30)

[...] a ciência da informação tradicionalmente e, em nome da interdisciplinaridade, emprestou de outras disciplinas conceitos, muitas vezes, sem uma reflexão epistemológica do impacto das possíveis incongruências e incompatibilidades teóricas para a delimitação de sua identidade científico-disciplinar. (p.30)

[...] é importante para a história dos conceitos a distinção entre conceito e palavra. (p.31)

[...] Koselleck (1992) demarcou cinco pontos relevantes para o desenvolvimento da história dos conceitos, respectivamente: 1) o conceito teorizável; 2) a utilização e o emprego de conceitos; 3) relação entre conceito e contexto no processo de apreensão; 4) unicidade conceitual; 5) como mensurar a força diacrônica do conceito. (p.32)

[...] a polissemia dos conceitos está condicionada à diversidade da experiência histórica [...]. (p.33)

[...] se pensarmos as particularidades de um conceito científico, poderemos dizer que ele é um importante indicador do comportamento de determinada comunidade científica [...]. (p.33)

[...] Koselleck $(1992$, p.3) demonstrou que o trabalho do historiador do conceito transcende àquele historiador hermenêutico da linguagem por considerar teoricamente "[...] errônea toda postura que reduz a história a um fenômeno de linguagem, como se a língua viesse a se constituir na última instância da experiência histórica”. (p.33)

[...] a palavra pode permanecer a mesma [...], no entanto, o seu conteúdo altera-se substancialmente. (p.34)

[...] o conteúdo falado pragmaticamente será único e irrepetível (uma situação singular) em um jogo persuasivo entre comunicador e receptor da mensagem. Por outro lado, o conteúdo comunicado só será apreendido se o receptor tiver o conhecimento prévio da semântica (significado das palavras), empregada no ato comunicativo. (p.34)

[...] o tempo da relação semântica diacrônica é mais lento do que o tempo do uso pragmático da língua que ocorre de forma sincrônica. (p.35)

Durante o processo de formaçãolformalização de uma teoria científica, poderíamos dizer que o termo é imediato e o conceito é mediato. (p.37)

[...] o estudo histórico do conceito, na perspectiva epistemológica, pode ampliar e aproximar a dimensão teórico-científica em que o conceito está inserido à gênese filosófica que contribuiu para a sua constituição. Em termos mais objetivos, quanto mais se busca a cientificidade de uma determinada "ciência" (por meio, por exemplo, do estudo histórico-conceitual), mais é possível se aproximar de sua gênese filosófica. (p.37) 
p) Artigo 39: o foco principal do artigo é a construção de conceitos no campo disciplinar e científico da Ciência da Informação. A principal perspectiva do artigo é epistemológica. Discute a dificuldade de construção de um corpo teórico-conceitual na área.

[...] o termo "Ciência da Informação" funciona como mero significante, ou seja, que o mesmo propõe-se como uта forma vazia \, podendo ser preenchida circunstancialmente. (p.1)

O termo não se define pelo que é, mas pelas possíveis apropriações que realiza em campos do saber [...]. (p.2)

[...] as expressões lingüísticas são utilizadas de diferentes maneiras. Observadas pela lógica clássica, tais expressões têm a função de fazer-nos conhecer a proposição, a idéia, isto é, a realidade objetiva a que se refere o conceito, ou permite atribuir-lhe um julgamento. (p.6)

[...] no âmbito das Ciências Humanas e Sociais, não resulta de uma insuficiência da linguagem a ambigüidade e o equívoco que nos afasta das expressões de idéias claras e distintas. Não se pode delas eliminar a contingência, o processo histórico e a realidade social; de modo geral a possibilidade de diversas interpretações, em sua maioria baseadas num recurso à experiência. Neste contexto, próprio da controvérsia, a condição fundamental da lógica - a univocidade entre o termo e o conceito - não pode ser obtida. (p.6)

[...] não se identifica, na área, um sistema conceitual elaborado. (p.6)

[...] o conceito na área participa de uma cadeia aberta de significação, que compromete o trabalho intelectual, substituindo o processo de geração de conhecimento por um esforço de convencimento sobre a existência a importância da Ciência da Informação. (p.6)

Os termos utilizados pela área não refletem conceitos, mas remetem a procedimentos práticos, instrumentos que regulamentam as aplicações práticas ou a outras áreas do conhecimento. (p.7)

[...] o levantamento terminológico permite uma interpretação que enfatiza a fragilidade - conceitual e, portanto, epistemológica e acadêmica - da área pela insuficiência na consolidação de uma linguagem de especialidade (Sager 1993). (p.7)

A terminologia da área reúne uma série de unidades lexicais mas não permite entrever o sistema conceitual que deveria conferir um estatuto epistemológico à área. Diante da ausência de um sistema conceitual explicitado, os termos utilizados pela área não remetem a conceitos. (p.9)

Não existe um acordo fundamental e uma linguagem de especialidade de natureza científica que comunique uma realidade integrada. A fragmentação conceitual, o recurso constante a terminologias de outras áreas, a ausência de projeto de consolidação acabam retardando o desenvolvimento da área. (p.9)

[...] a Ciência da Informação se enuncia formalmente como um objeto teórico que carece de construção conceitual. As manifestações aplicadas, realizadas em seu âmbito, não têm potencial para construir o objeto teórico, mas ressaltam os campos de aplicação e os problemas enfocados pela área. (p.10)

A análise dos textos deste segmento mostra que questões de base filosófica, lingüística, semântica estão presentes nas discussões sobre os conceitos. Observa-se, no entanto, que a maioria dos textos não discute de forma aprofundada as posições paradigmáticas da área. De forma geral, são citados autores identificados com diferentes perspectivas (Wittgensten, Eco, Deleuze e Guattari, Foucault), porém, as posições destes teóricos não são confrontadas, por exemplo, com as dos positivistas lógicos. 
Estas últimas fundamentam as teorias sobre o conceito largamente adotadas no campo da Organização da informação e do conhecimento.

\section{ARTIGOS TEÓRICO-METODOLÓGICOS}

Os artigos que incorporamos à categoria de artigos "teórico-metodológicos" são: $1,2,3,7,8,9,10,11,12,13,14,15,16,17,19,25,26,27,28,31,32,33,34,35,37$, 42.

No campo das palavras-chave dos artigos teórico-epistemológicos não foi encontrado um padrão, aspecto que se distingue do que ocorre nos artigos teóricometodológicos, pois, além de existir um número maior de artigos com o termo conceito e suas variantes, no campo das palavras-chave, outros termos ocorrem com frequência neste segmento do corpus: teoria do conceito (artigo 1); conceitos (artigo 2); teoria do conceito (artigo 3); conceito (artigo 7); gráficos conceituais (artigo 8); sistemas de conceitos e estruturação de conceitos (artigo 11); tesauro conceitual (artigo 12); teoria do conceito (artigo 14); modelagem conceitual e teoria do conceito (artigo 16); modelagem conceitual (artigo 17); modelagem conceitual (artigo 25); modelagem conceitual (artigo 26); mapa conceitual (artigo 27); sistemas de conceitos (artigo 31); sistemas de conceitos (artigo 32).

É possível verificar que os termos "modelagem conceitual" e "sistemas de conceitos" são os que mais aparecem no campo das palavras-chave destes artigos, indicando uma tendência de pesquisa que se consolida na área. Além das questões de método propriamente ditas, nossa intenção, nesta análise, é identificar as correntes teóricas que fundamentam as abordagens. A análise dos artigos é apresentada a seguir:

a) Artigo 1: compara as bibliotecas tradicionais e digitais, do ponto de vista da organização da informação. Apresenta uma revisão sobre o conceito, com base na Teoria do conceito de Dahlberg, relacionando-a aos metadados, às ontologias e ao processo de classificação. Retoma o livro o "Significado de significado" de Ogden e Richards, lembrando que os estudos sobre o conceito remontam ao período grego e medieval. Pontua a influência aristotélica em Dahlberg e Ranganathan.

O que na realidade se classifica em uma biblioteca tradicional ou digital não são os documentos, mas os conceitos contidos nesses documentos. (p.7)

$O$ estudo da gênese e formação dos conceitos vem sendo feito ao longo da história do pensamento filosófico e científico, em diversos campos disciplinares, destacando-se a filosofia, a semântica, a 
psicologia, a biblioteconomia, a terminologia, sempre envolvendo as bases cognitivas e lingüísticas do conhecimento e saberes humanos. (p.8)

Por teoria do conceito entende-se [...] o conjunto de enunciados oriundos de pesquisas e reflexões pertinentes à complexa região epistemológica interdisciplinar que compreende o ato de representação, comunicação e preservação de objetos e pensamentos e cujo conhecimento integra os campos da linguagem, da psicologia cognitiva, da comunicação e da ciência da informação. (p.8)

Embora muito se fale sobre o conceito, nem sempre se tem clareza de seu significado. (p.8)

Dahlberg chama atenção para um fato relacionado aos componentes essenciais de um conceito relativo a um referente qualquer. Considerando-se que, para Aristóteles,o significado do conceito (horos) incluía três elementos, logos, pragma e noema, Dahlberg ressalta que, no processo de tradução de horos, a partir do pensamento do filósofo grego, Boethius tenha vertido o termo para o latim utilizando-se o vocábulo terminus, que privilegia somente o logos, o lado lingüístico do conceito; ficou portanto falha a correspondência do termo. (p.8)

O triângulo de Ogden \& Richards, publicado no clássico livro "O significado de significado...", publicado em primeira edição em 1923, edição brasileira de 1972, tem sido muito utilizado para se representar o conceito devido a sua clareza e facilidade de compreensão. O referido diagrama espelhase em um triângulo em que, no vértice superior encontra-se o objeto da realidade; no vértice da direita o conceito, formado de todos os enunciados que podem ser proferidos sobre o referente; e no vértice da esquerda encontra-se o símbolo, o signo, termo, número, ícone, designando o conceito sobre o objeto referente. (p.8)

São recorrentes, desde a antiguidade grega as discussões sobre as conexões entre as palavras e as coisas, entre os referentes (coisas, pensamentos), seus conceitos e respectivos símbolos usados para sua representação. (p.9)

Na Idade Média, as discussões sobre o uso de termos e conceitos, no intento de se definir as coisas, chegaram a dar origem a duas correntes diferentes de pensadores: os nominalistas e os conceitualistas. (p.9)

No pensamento de Aristóteles, encontram-se contribuições bastante relevantes para a teoria do conceito, envolvendo o ato da cognição humana e a fatoração do conceito em categorias [...]. (p.9)

Para Aristóteles, "saber seria ter muitos conceitos e conhecer significava três coisas":

1. formar conceitos, ou seja, constituir em nossa mente um conjunto de notas características para cada uma das essências que se realizam na substância individual;

2. aplicar esses conceitos que formamos a cada coisa individual, colocar cada coisa individual sob um conceito. Chegar à natureza; contemplar a substância; olha-la e voltar para dentro de nós mesmos para procurar no arsenal de conceitos aquele que se ajustasse a uma singular substância; e formular um juízo;

3. embaralhar entre si esses diversos juízos, em forma de raciocínios que nos permitissem chegar à conclusão acerca de substâncias que não temos presentes. (p.9)

Um clássico trabalho sobre a gênese dos conceitos na mente humana e sua extrapolação para o campo da organização e recuperação de informações é de autoria de Jesse Shera [...]. Shera publicou importante trabalho nos proceedings da Conferência Internacional de Classificação e Recuperação de Informações, realizada em Londres sob os auspícios da ASLIB, em 1957. Seu trabalho tem por objetivo o aperfeiçoamento da organização e recuperação de registros gráficos e ilustra muito bem como se desenvolve, no cérebro humano, o processo de formação de conceitos. (p.9)

Segundo Shera, "Um conceito é uma rede de padrões de inferências, associações e relacionamentos que são predicados ou ditos de outra forma trazidos em cena através do ato da categorização"[...] a cristalização ou formalização do pensamento inferencial, nascida da percepção sensorial, condicionada pela operação do cérebro humano e delineada pela experiência humana. Ela repousa na fundamentação de todo pensamento mas ela é pragmática e instrumental. É permanente e efêmera. Permanente porque sem ela, a cognição é impossível; efêmera porque ela pode ser rejeitada quando sua utilidade é esgotada" (Shera, 1957). (p.10)

Os conceitos e os diversos elementos que contribuem para a formação de conceitos, mais ou menos intensos, constantes dos livros e outros documentos constituem-se no material da classificação. (p.10) 
São essas unidades de pensamento e as relações entre elas, como estão presentes nas páginas dos documentos e na mente do usuário, que se constituem na primeira preocupação do bibliotecário e o compele a sucessivas considerações sobre o papel da classificação. (p.10)

[...] a classificação facetada, preconizada por Ranganathan [...] permite uma grande multiplicidade de combinações de conceitos, possibilitando uma estruturação semântica dos conceitos de um documento. (p.12)

[...] a teoria do conceito, esboçada anteriormente, aos seres concretos e abstratos correspondem os conceitos compostos de enunciados sobre esses mesmos seres e a esses conceitos são atribuídos seus respectivos nomes ou símbolos que, nos documentos textuais mais convencionais acham-se representados por termos. Daí as relações entre ontologias, conceitos e terminologia. (p.14)

A filosofia e a psicologia do conhecimento, denominação esta usada por Dahlberg, foram campos específicos, onde a gênese e a organização do conhecimento constituíram-se em objetos privilegiados de estudo do conceito. A biblioteconomia e a ciência da informação, que desde seus primórdios contou com a atuação de pensadores eruditos e com ampla visão do campo científico, incorporou esses conhecimentos em seu corpo teórico, levantando as questões específicas da área, ou seja, utilizando métodos de pesquisas e princípios de reflexão, a partir de seus objetos específicos voltados aos processos de organização e recuperação de informações. (p.17)

A teoria do conceito, na qual se fundamentam as categorias de Aristóteles, retomadas com ligeiras alterações por Ranganathan, e que propiciam a análise dos conceitos em ângulos diversos de abordagem, as facetas, tem sido considerada por muitos a "luz no fundo do túnel" vislumbrada como insumo potencial para a criação de novas ferramentas destinadas à resolução do grande problema atual da ciência que pode ser identificado na confluência dos processos de produção, representação e organização de conhecimentos. (p.18)

Outra pista para uma proposta de sistematização estrutural do conhecimento pode estar numa proposição lógica emanada do pensamento do filósofo Leibniz.

De acordo com Leibniz: "A infinita variedade de pensamentos é somente aparente; ela se origina do número infinito de possibilidades por meio das quais os pensamentos básicos podem ser combinados uns com os outros [...] todos os pensamentos humanos podem ser reduzidos a alguns poucos pensamentos originais que, quando identificados podem servir como um alfabeto dos pensamentos humanos. Similarmente ele insiste que a maioria dos conceitos podem ser subdivididos em subconceitos e esses em outros até que se atinja conceitos tão elementares que não sejam mais possíveis de qualquer decomposição" (p.18)

O conceito pode ser visto como fator invariante envolvido na concepção e tratamento de documentos, quando se fala da evolução das bibliotecas tradicionais para as digitais. Daí a complexidade das propostas de tratamento automático de objetos digitais, estando envolvidos nesse processo as chamadas ontologias, os metadados, cabeçalhos de assuntos, tesauros, pontos de acesso, dentre outros componentes. (p.19)

b) Artigo 2: Assim como o artigo 1, este também apresenta uma análise do ambiente digital, porém seu foco principal é a representação de informação. Neste caso, trata o conceito como representação primária e secundária. Aborda o conceito a partir da ontologia, da formação dos conceitos a partir dos enunciados sobre os "seres". Também apresenta os conceitos na filosofia e na ciência. Aborda os conceitos em Aristóteles e na Idade média, retomando também Shera, Dahlberg e Wüster.

Os seres expostos ao processo de conhecimento, ou seja, os seres sobre os quais se pensa, sobre os quais se enuncia e sobre os quais se constrói um conceito, integram a essência do campo que os filósofos denominam de ontologia: universo de todos os seres concretos e abstratos existentes. (p.21)

Dos enunciados sobre os seres gera-se o chamado conceito, unidade de conhecimento referente ao ser percebido, componente essencial do conhecimento a ser representado. (p.22) 
[...] no processo de tratamento ou processamento dos registros de conhecimento para fins de armazenagem nos sistemas de informação, é requerido um novo estágio de representação, desta vez. partindo-se não do ser ontológico em si, mas do conhecimento sobre o ser, expresso em documentos. Esta seria uma representação secundária. (p.22)

[...] a representação secundária teria por objeto prioritário não o acervo da ontologia, das coisas e seres existentes, mas o acervo de conhecimentos sobre essas coisas e seres, objetos da epistemologia. (p.22)

Na representação primária, os produtos finais são constituídos de conceitos sobre os seres, formando o conhecimento, conceitos mais ou menos intensamente detalhados, codificados através de uma linguagem simbólica. (p.22)

Na representação secundária, prática essencial nos sistemas de informações documentais, esses mesmos conceitos constantes dos registros primários são sucintamente identificados em seus elementos constitutivos fundamentais, escolhendo-se os pontos de acesso fundamentais que garantem a representação desse conhecimento (documento) para fins de futura recuperação. (p.22)

Sintetizando pode-se dizer que o processo cognitivo e seu produto, o conceito, materializam o conhecimento das coisas, dos seres sobre as quais incide a nossa cognição (onto - ser) e o resultado dos registros de nossa atividade cognitiva dá origem ao conhecimento (episteme). (p.23)

Segundo Ferreira, ontologia consiste "na parte da filosofia que trata do ser enquanto ser, isto é, do ser concebido como tendo uma natureza comum que é inerente a todos e a cada um dos seres”. (p.23-24)

Os conceitos mais ou menos intensos e os diversos elementos para a formação de conceitos, constantes de livros e de outros documentos, constituem-se no material da classificação. São essas unidades de pensamento e as relações entre elas, como se apresentam nas páginas dos documentos e na mente do usuário, preocupações basilares do trabalho desenvolvido pelos profissionais responsáveis pelo tratamento desse tipo de informação.

Considerando-se o aspecto da representação simbólica do conceito, emerge o papel da terminologia, no contexto amplo da produção e organização da ciência e da tecnologia. Sabe-se que nenhuma disciplina pode progredir sem a socialização da linguagem entre os membros da comunidade que a sustenta. (p.25)

A cognição se materializa através da formação dos conceitos que são "unidades de conhecimento", compostas de declarações verdadeiras sobre um item específico de referência representado por uma forma verbal. (p.31)

Por teoria do conceito entende-se [...] o conjunto de enunciados que compõem a complexa região epistemológica interdisciplinar que compreende o ato de representação, comunicação e preservação de conhecimentos e cujos conhecimentos integram os campos da linguagem, da psicologia cognitiva, da comunicação e da ciência da informação. Na ciência da informação, o estudo dos conceitos recebeu significativas contribuições de Dahlberg e seu grupo e de Eugen Wüster, ambos pertencentes a escolas alemãs, respectivamente nos campos da biblioteconomia e da terminologia. (p.31)

É freqüente nos estudos sobre o conceito uma recorrência ao pensamento de Aristóteles, considerando-se as bases e a influência das teorias desse pensador na estruturação de conceitos e conhecimentos, em todas as épocas da evolução do pensamento filosófico e científico. (p.32)

Na Idade Média, as discussões sobre o uso de termos e conceitos, na definição das coisas chegaram a originar duas correntes diferentes de pensadores: a dos nominalistas e a dos conceitualistas. (p.32)

Um clássico trabalho sobre a gênese dos conceitos na mente humana e sua extrapolação para o campo da organização e recuperação de informações é de autoria de Jesse Shera [...]. Seu trabalho teve por objetivo o aperfeiçoamento da organização e recuperação de registros gráficos e procurou ilustrar como se desenvolve no cérebro humano o processo de formação de conceitos. (p.32)

Segundo Shera, "Um conceito é uma rede de padrões de inferências, associações e relacionamentos que são predicados, ou ditos de outra forma, trazidos em cena através do ato da categorização” (1957, p.19). (p.33)

Estudos teóricos que tenham por objeto a representação, a ontologia, a epistemologia, o conceito, a cognição e a hermenêutica são apenas alguns dos inúmeros tópicos teóricos que esclarecem facetas fundamentais para se estudar os fenômenos essenciais da área. (p.38) 
c) Artigo 3: o foco principal deste artigo é a Teoria da classificação. Comenta os princípios da lógica aristotélica e analisa a teoria da classificação facetada de Ranganathan, a teoria do conceito de Dahlberg, e a Teoria da classificação de Vickery. As relações entre os conceitos são abordadas com objetivos operacionais.

[...] diversos campos e setores de pesquisa estabeleceram diálogo ou se apropriaram dos princípios da teoria da classificação facetada, tais como a metodologia para a construção de tesauros facetados (AITCHISON; GILCHRIST, 1979), a teoria do conceito (DAHLBERG, 1978) [...]. (p.128)

O conceito pode ser entendido como "todo processo que torne possivel a descrição, a classificação e a precisão de objetos cognoscíveis" (INÁCIO FILHO, 1995, p. 65). Sua transformação em categoria é um processo, pois as categorias são "leis fundamentais do pensamento" e "fornecem subsídios teóricos para o processamento da investigação" (INÁCIO FILHO, 1995, p. 67). O que diferencia a ambas é que "a categoria é um conceito que ocupa uma posição-chave no contexto de uma teoria determinada. Essa posição-chave é definida pelo processo ou pelo enfoque" (INÁCIO FILHO, 1995, p. 68). (p.129)

Esse processo de passagem do conceito para a categoria é explicitado por Dahlberg a partir da idéia de "elementos dos conceitos". Para a autora, um conceito se forma a partir dos enunciados que se fazem sobre ele. Cada enunciado contém um elemento ou característica do conceito, podendo-se "definir a formação de conceitos como a reunião e compilação de enunciados verdadeiros a respeito de determinado objeto" (DAHLBERG, 1978, p. 102). (p.129)

A autora destaca duas dimensões ou propriedades a serem consideradas sobre os conceitos. A primeira se estrutura a partir das noções de extensão e intensão oriundas da semiótica peirceana, sendo a extensão a propriedade de um termo ou conceito de cobrir um vasto campo de objetos (grande generalidade) e a intensão a limitação dentro de um campo, o aprofundamento de características particulares restritas a um grupo menor ou a apenas um objeto (grande especificidade). Assim, a intensão representa a soma total das características e a extensão, a soma total de conceitos mais específicos. (p.129-130)

Há ainda uma outra distinção. De um lado, existem os objetos individuais: "toda vez que um objeto é pensado como único, distinto dos demais, constituindo uma unidade inconfundível" (DAHLBERG, 1978, p. 101). De outro, há os objetos gerais, que "prescindem das formas do tempo e do espaço" (DAHLBERG, 1978, p. 101). Estes dois termos estão na origem da distinção entre conceitos gerais e conceitos individuais dentro de um sistema de classificação. (p.130)

Considerando-se essas duas propriedades, e também que a formação de conceitos se dá na reunião de enunciados verdadeiros sobre ele (os enunciados são características ou atributos dos conceitos), deve-se avaliar os tipos de características ou de enunciados. Esse é o passo necessário para a criação das categorias, ou facetas, que promovem as possibilidades de ligação de cada conceito com o assunto que está sendo classificado. (p.130)

[...] essas características podem ser de duas espécies: as essenciais ou necessárias (aquelas que são necessárias para a definição do conceito, servem para diferenciar o objeto ao qual esse conceito se refere de outros objetos) e as acidentais, adicionais ou possíveis (não são características que definem o objeto desse conceito). (p.130)

[...] é necessário que se determine o tipo dos enunciados que são feitos sobre os conceitos. As espécies de características podem ser várias, sendo as dez categorias aristotélicas um bom exemplo, "útil para aplicação de categorias simples mas não exclui a possibilidade de combinações entre elas" (DODEBEI, 2002, p. 98). Contudo, deve-se destacar que "Dahlberg faz uma releitura dessas categorias, reagrupando-as no que denomina supercategorias" (DODEBEI, 2002, p. 98). As supercategorias, para Dahlberg, são: entidades (princípios, objetos imateriais, objetos materiais), propriedades (quantidades, qualidades, relações), atividades (operações, processos, estados) e dimensões (tempo, espaço, posição). (p.131)

[...] é essencial também realizar uma discussão sobre as relações entre os conceitos [...] Assim, as características dos conceitos não têm por função apenas a definição dos conceitos, mas também sua ordenação classificatória. (p.131)

A autora identifica as seguintes relações entre os conceitos (DAHLBERG, 1978, p. 104-105):

a) Relações lógicas (baseadas na posse de características comuns): 
- Identidade (as características são as mesmas);

- Implicação (o conceito A está contido no conceito B);

- Intersecção (os dois conceitos coincidem em algum elemento);

- Disjunção (nenhuma característica em comum);

- Negação (o conceito A possui características cuja negação está no conceito B).

b) Relações semânticas:

- Relações hierárquicas (a relação de gênero e espécie, quando "dois conceitos diferentes possuem características idênticas e um deles possui uma característica a mais que o outro”);

- Relações partitivas (que existem entre um todo e suas partes, ou um produto e os elementos que o constituem);

- Relações de oposição (de contradição ou contrariedade);

- Relações funcionais (conceitos que expressam processos). (p.131-132).

Outra distinção é feita por CAVALCANTI (1978, p. 43) que apresenta as relações de equivalência (sinônimos e quase-sinônimos), hierárquicas (que podem ser genéricas ou partitivas) e associativas (ou de afinidade), que podem ser de conceitos opostos, genéticas (quando um objeto precede o outro), de coordenação (quando são derivados de um mesmo termo genérico), de causa e efeito, de relação instrumental, de relação material (quando uma coisa dá origem a outra) e de similaridade. (p.132).

Conclui-se assim [...] que se pode estruturar o processo de construção de um sistema facetado a partir das seguintes etapas:

a) De formação de conceitos: escolha do conceito, coleta dos enunciados verdadeiros sobre ele, seleção dos enunciados redundantes ou que estão contidos nos outros, determinação dos enunciados essenciais e acidentais e determinação dos tipos de enunciados;

b) Relações entre os conceitos: determinação dos tipos de conceitos, determinação das relações entre eles; análise de intensão e extensão dos conceitos; observação dos princípios lógicos de classificação (completude, irredutibilidade e exclusividade mútua).

c) Organização do esquema facetado: definição do assunto e das fronteiras; levantamento de facetas; levantamento das subfacetas; decisão da ordem de citação das facetas e subfacetas; agrupamento das subfacetas. (p.133)

d) Artigo 7: a dimensão operacional também predomina neste artigo, que aborda as questões semânticas da terminologia da área médica.

Tanto a compatibilização conceitual de coletividades com singularidades, enquanto unidades do conhecimento médico, apontada na primeira perspectiva descrita acima, quanto a aproximação conceitual de bases do conhecimento com processos de tomada de decisão, delineada na segunda perspectiva, podem se beneficiar do desenvolvimento de instrumentos de tratamento informacional que permitam a superação de algumas das limitações que podem ser encontradas em abordagens de recuperação informacional amplamente utilizadas, tais como a lexical e a estatística. (p.6)

Listas alfabéticas podem permitir a ordenação de léxicos em função da representação gráfica e fonética dos termos empregados na área do conhecimento em questão, sem contudo permitir a recuperação das informações necessárias para o usuário a partir dos conceitos que formam a base do seu raciocínio e de seus processos de tomada de decisão. (p.6)

A ausência ou escassez na utilização de relações semânticas nas bases de conhecimento, como instrumentos de tratamento informacional, desenvolvidas no nível dos conceitos associados aos termos contidos nestas bases, assim como no nível de suas relações conceituais, determina uma importante redução no grau de precisão do processo de recuperação informacional através dos instrumentos usualmente utilizados para este fim, de um lado em função da relevância clínica dos termos empregados na busca não ser considerada, bem como, de outro lado, pelo fato das necessidades de busca pacienteespecíficas por parte dos profissionais não se encontrarem contempladas em sistemas com estas características. (p.7)

[...] pode-se proceder à construção de ontologias do conhecimento médico, enquanto especificações explícitas de conceitualizações desenvolvidas neste domínio do conhecimento. Estas conceitualizações são compreendidas como estruturas semânticas formais, definidas por relações intensionais, estruturas estas que codificam as regras implícitas que restringem a estrutura de um elemento da realidade. (p.13) 
e) Artigo 8: discute a aplicabilidade dos gráficos conceituais (Sowa), na websemântica.

A teoria dos gráficos conceituais (GCs) começou a ser desenvolvida por Sowa em 1968 [...]. (p.7)

[...] Sowa aplicou a idéia de fluxogramas para criar um modelo de representação de conhecimento em Inteligência Artificial que se utiliza de caixas e círculos para gerar Gráficos Conceituais (GCs). (p.7)

Como modelo de representação do conhecimento que utiliza uma notação em gráficos, os GCs são, para Sowa [...] " uma síntese dos gráficos existenciais de Peirce, dos gráficos de dependência de Tesnière e das redes semânticas da Inteligência Artificial.» (p.7)

Os GCs formam uma linguagem de representação do conhecimento e são constituídos por gráficos que possuem dois tipos de nós:

a) os conceitos, representados por retângulos ou por colchetes [CONCEITO], correspondem a conteúdos de pensamento; representam entidades, ações ou estados que possam ser descritos em termos de linguagem; $e$

b) as relações, representadas por círculos com uma flecha de entrada e outra de saída ou entre parênteses $=>($ RELAÇÃO $)=>$, simbolizam as ligações existentes entre os conceitos e demonstram os papéis que cada entidade desenrola. (p.7-8)

Para Sowa [...], «os gráficos conceituais formam uma base semântica da linguagem natural $e$ representam modelos do mundo real ou de um mundo possível.» (p.8)

f) Artigo 9: Aborda as classificações analítico-sintéticas por meio da análise de conteúdo de artigos sobre a classificação facetada de Ranganathan. Apresenta uma revisão, a partir de pesquisa empírica, sobre a classificação analítico-sintética. Analisa artigos de pesquisa teóricos e de aplicação sobre o tema.

Os modelos baseados na lógica analítico-sintética superam em grande parte outros métodos como aqueles aplicados somente na elaboração de estruturas hierárquicas. Dahlberg (1978, p.105), ao descrever o método de categorização conceitual utilizado nas classificações facetadas, ressalta suas “[...] possibilidades inúmeras de combinações entre as categorias”. (p.238)

É no contexto dos instrumentos de representação do conhecimento que seguem o princípio analíticosintético que se delimita este artigo. Seu conteúdo é resultado da primeira parte da pesquisa "Critérios lingüísticos adotados em modelos de organização do conhecimento”, do Programa de Pós-graduação em Ciência da Informação da Universidade Federal de Santa Catarina. Essa parte do projeto teve como objetivo levantar os critérios lingüísticos adotados por instrumentos utilizados na organização de conhecimento para recuperação da informação. Observou-se que a maioria das publicações encontradas não tratava de forma explícita dos critérios lingüísticos. No entanto, por meio da descrição de experiências teóricas e aplicações práticas, deixavam registradas algumas indicações a esse respeito. Após a descrição da metodologia adotada, apresentamos um resumo de cada texto identificado, trazendo uma síntese das questões teóricas e metodológicas nele descritas. (p.239)

No campo das reflexões teóricas, trabalhos que abordam normas e padrões de desenvolvimento de tesauros mostram lacunas no que diz a respeito à utilização de métodos de análise facetada na construção desses instrumentos. Isto é o que procura comprovar o artigo de Spiteri (1997) [...]. (p.239)

[...] Hjorland (2002) ressalta a pouca cientificidade dos métodos de elaboração de classificações. [...] ele aponta quatro problemas básicos com relação à abordagem analítico-sintética: a) falta de métodos empíricos explícitos, b) falta de atualização metodológica, c) falta de comparação com outros métodos e) falta de reconhecimento formal na área da Ciência da Informação. (p.242)

Em busca de princípios fundamentais que apóiem o processo de modelização de domínios de conhecimento, Campos (2004) apresenta uma análise comparativa de teorias desenvolvidas para esse fim pela Ciência da Informação, Terminologia e Ciência da Computação. A Teoria da Classificação Facetada, juntamente com a Teoria do Conceito de Ingetraut Dahlberg, constituem aquelas escolhidas da Ciência da Informação, uma vez que abordam a representação de sistemas de conceitos. (p.242) 
Mills (2004) expõe o importante papel da classificação facetada na recuperação da informação. Concentra sua explanação na estruturação da divisão lógica desse tipo de classificação [...]. (p.242)

Em um contexto de cunho conceitual, Maniez (1999) tece comentários sobre o uso nem sempre preciso do termo "faceta" por especialistas em Ciência da Informação. [...] Após relatar que o conceito do termo foi originalmente determinado por Ranganathan, Maniez. (1999) explora a aplicação das facetas nos eixos paradigmáticos e sintagmáticos propostos pela Lingüística e conclui que Ranganathan pretendia encontrar a sintaxe absoluta na descrição dos assuntos, o que é contestado por diversos autores. (p.242)

Após uma explanação sobre estudos na área de cruzamento entre lingüística e documentação e no domínio da representação documentária, Pereira e Bufrem (2005) fundamentam o artigo citando as reflexões de Maria Luiza Campos no que se refere aos princípios comuns presentes na Teoria do Conceito (Dahlberg), a Teoria Geral da Terminologia (Wüster) e a Teoria da Classificação Facetada (Ranganathan). (p.243)

Em Tristão, Fachin e Alarcon (2004), os autores sintetizam conceitos relacionados à classificação facetada e tesauro. [...] discorrem também sobre as intersecções entre tesauro e as classificações em facetas e tratam da Teoria do Conceito e sua aplicação na construção das classificações. (p.244)

Lima (2002) apresenta uma revisão de literatura sobre aplicações da Teoria da Classificação Facetada na resolução de questões relacionadas à organização conceitual em sistemas hipertextos [...]. (p.244)

No que tange às aplicações práticas da classificação facetada, os documentos analisados apresentavam uma tipologia variada. Esse fato revela a atualidade do método analítico-sintético [...]. (p.244)

[...] Campos (2001) discute questões relativas à elaboração de sistemas voltados à organização do conhecimento, em especial os hiperdocumentos. [...] utiliza como fundamentação teórica e metodológica a Teoria da Classificação, a Terminologia, o método Orientado a Objetos e a Ontologia [...]. (p.244)

[...] Campos e Gomes (2005) [...] relatam ter o Método Facetado, concebido por Ranganathan, e a Teoria do Conceito, elaborada por Dahlberg, as bases teóricas e metodológicas essenciais para a construção de hiperdocumentos [...]. (p.244)

[...] Lima (2004) [...] Com base na problemática da inexistência de critérios semânticos durante a construção dos hipertextos e suas conseqüências na eficiência do processo de recuperação, a autora propõe um modelo hipertextual aplicado a teses e dissertações. Esse modelo toma por base as teorias da Análise Facetada e de Mapa Conceituais [...]. (p.244-245)

$O$ registro de pesquisas sobre reflexões teóricas e aplicações levantadas por esta pesquisa mostra a importância e a atualidade dos instrumentos que seguem o princípio analítico-sintético. As questões teóricas refletem preocupações quanto à clareza dos conceitos sobre facetas. No intuito de tornar essas noções mais precisas, alguns autores propõem sínteses, outros utilizam o método comparativo ou da análise da utilização desses conceitos em documentos normativos e metodologias de construção de modelos facetados. No que concerne às aplicações, são de natureza múltipla e atual, o que vem comprovar a adaptabilidade do método. (p.248)

g) Artigo 10: o foco do artigo são os aspectos teórico-metodológicos da modelização de domínios do conhecimento. Analisa a Teoria da classificação facetada de Ranganathan, a Teoria do conceito de Dahlberg, a Teoria geral da terminologia de Wüster e a ontologia de Guarino. Faz tais análises em um contexto de complexidade, baseado em Morin. Aborda a modelização a partir de Le Moigne. Faz a análise sobre representação do conhecimento nos níveis lógico, epistemológico, ontológico e conceitual. Neste caso, aborda as estruturas, relações, sistemas e modelização de conceitos.

Esta investigação discute a problemática representacional [...]. (p.22) 
Da ciência da informação, analisam-se teorias ligadas mais especificamente à representação de sistemas de conceitos, como a teoria da classificação facetada de S. R. Ranganathan (Ranganathan, 1951, 1967) $e$ a teoria do conceito de I. Dahlberg (Dahlberg, 1978, 1978 a, 1983) [...]. (p.22)

Da ciência da computação, investigam-se os modelos representacionais associados à modelagem de sistemas de banco de dados, mais especificamente o modelo orientado a objetos (Gray, 1992; Furlan, 1998; Rumbaugh, 1994), além de um campo mais recente que repensa as possibilidades representacionais e de organização de domínios de conhecimento - a ontologia formal (Guarino, 1998, 1998 a, 1994, 1997; Gruber, 1993; Sowa, 2000). (p.22)

Da teoria da terminologia, utilizam-se princípios estabelecidos para a determinação de conceitos e suas relações apresentadas por E. Wuester (Wuester, 1981) e seus seguidores (Drozd, 1981; Felber, 1981, 1984; Kandelaki, 1981; Riggs, 1979). (p.22)

Entende-se modelização a partir dos estudos desenvolvidos por Le Moigne, em sua teoria do sistema geral, também denominada teoria da modelização (Le Moigne, 1977). (p.23)

Le Moigne afirma que conhecer é modelizar, ou seja, o processo de conhecer equivale à construção de modelos do mundo/domínio a ser construído que permitem descrever e fornecer explicações sobre os fenômenos que observamos. (p.23)

O nível lógico é o nível da formalização. Não existe, entretanto, preocupação com a semântica em termos dos conceitos e de suas relações; na verdade, todo o foco está centrado em uma dada "sintaxe" que possibilite uma verdadeira ação do pensar. (p.24)

No nível epistemológico, a noção genérica de um conceito é introduzida como uma primitiva de estruturação de conhecimento; ele é o nível da estruturação. (p.24)

O nível ontológico tem por objetivo restringir o número de possibilidades de interpretação do conceito dentro de um dado contexto, a partir de um formalismo que pretende representar o conteúdo do conceito. (p.24-25)

No nível conceitual, independentemente de um formalismo, os conceitos possuem, a priori, uma interpretação definida. (p.25)

Na perspectiva da ciência da informação, da ciência da computação e da terminologia, interessam-nos aqueles níveis em que uma estrutura de conhecimento possa ser sistematizada e representada a partir de contextos específicos. (p.25)

Na ciência da informação, a teoria da classificação pode ser considerada em um nível de transição entre o nível epistemológico e ontológico: apesar de não pretender chegar à definição dos conceitos de um dado domínio, ela possui um formalismo que possibilita a representação do conhecimento. Já as teorias do conceito e da terminologia podem ser classificadas como de um nível ontológico propriamente, pois permitem a sistematização de conhecimentos e possuem diretrizes para a elaboração de definições. (p.25)

Na ciência da informação, a teoria da classificação facetada (Ranganathan, 1967) é representante de um modelo que utiliza o método dedutivo para classificar o conhecimento dentro de um domínio. Desta forma, possui mecanismos de representação para trabalhar com metaniveis conceituais - as categorias. É a partir delas que os conceitos são ordenados para formar classes de conceitos. (p.25)

No domínio da ciência da computação, a ontologia formal utiliza o método indutivo. [...] O processo é iniciado com a descrição bastante específica dos objetos de um contexto, desde sua identidade até a sua dependência com outros objetos. [...] Desta forma, ela está mais preocupada com os significados dos conceitos do que com sua estrutura. Entretanto, acreditamos que em toda definição está implícita uma classificação. (p.26)

Fora do domínio da ciência da computação, a teoria da terminologia pode também ser vista como aquela que suporta o método indutivo para pensar um dado contexto. Para Wuester, os conceitos (objeto/entidade/instância) associam-se um em relação aos outros, formando um sistema de conceitos. Entretanto, o sistema é formado a partir da análise do próprio conceito, e não do contexto em que ele está inserido. O contexto é visto como um a priori que só é possível identificar a partir do próprio conteúdo conceitual. Na terminologia, não se fala sequer em categorias ou universais. (p.26)

No âmbito da ciência da informação, por sua vez, a teoria do conceito introduz uma metodologia que poderíamos denominar híbrida - não só o método dedutivo e não só o método indutivo -, mas agregando os dois em um exercício de pensar o particular como um todo e o todo possuindo particulares. Dahlberg, 
no estabelecimento de sua teoria, apresenta categorias para representar contextos e, logo depois, analisa os conceitos de um contexto na perspectiva de ordená-los no interior dessas categorias. A princípio, sabe-se da existência das categorias (universais); entretanto, chega-se a elas, a partir de um processo indutivo de análise do conceito. (p.26)

No âmbito da ciência da informação, a teoria da classificação e a teoria do conceito se apresentam como teorias que suportam um dos primeiros esforços teórico-metodológicos que evidenciam a questão da unidade de representação. Ranganathan, em seu Prolegomena, introduz o conceito de isolado como a unidade mínima e manipulativa de um sistema de classificação. Dalhberg apresenta o Conceito como unidade mínima e o define como uma tríade - referente, características e nome. (p.26)

No âmbito da ciência da computação, no contexto da orientação a objetos [...] um objeto é um conceito. (p.27)

No espaço teórico da inteligência artificial, no âmbito da ontologia formal, Guarino (1998) propõe que os objetos, ou particulares, sejam classificados como concretos e abstratos. Comparativamente, na teoria do conceito, estes são considerados objetos gerais [...]. (p.27)

As relações entre os objetos de um dado contexto formam a estrutura conceitual deste contexto e são de natureza diversa. (p.27)

O primeiro movimento é a verificação, nas teorias e métodos apresentados, da existência de relações categoriais. Este tipo de relação reúne, em um primeiro grande agrupamento, os objetos por sua natureza, ou seja, entidades, processos, entre outros. (p.27)

A relação categorial aparece na teoria do conceito como relação formal-categorial; na teoria da classificação facetada, como categoria; na ontologia formal, como teoria dos universais. Nestas três teorias, a noção de categoria se coloca como um elemento agregador que reúne os conceitos em um nível mais alto de uma dada taxionomia. (p.27)

Na teoria da classificação facetada, entretanto, as categorias são predefinidas [...].(p.27)

[...] Dalhberg explicita, em seu trabalho Ontical Strutures (Dahlberg, 1978a), que tem por princípio a classificação proposta por Aristóteles na antigüidade clássica, categorias para o entendimento do conceito, e não para classificar um domínio de conhecimento/atividade [...]. (p.27)

[...] o entendimento do conceito está refém de um contexto que é classificado por conta dos conceitos que nele estão inseridos. Desta forma, o contexto e seus elementos estão em uma relação unívoca. (p.27-28)

[...] Dalhberg apresenta o conceito de propriedade como uma categoria, diferentemente de Ranganathan, que o coloca como uma manifestação de uma das categorias. (p.28)

Na ontologia formal, o conceito categoria aparece como o nível de análise da estruturação dos objetos de um domínio. [...] Guarino parte dos objetos (ontologia dos particulares) e nos apresenta a seguinte forma de análise: em todo contexto nos deparamos com objetos (contínuos ou ocorrentes) que estão em dada região temporal ou espacial. (p.28)

A categoria, especificamente, é considerada uma classe de nível mais amplo, tendo como função possibilitar uma classificação geral do domínio em questão. Neste ponto, encontramos semelhança entre Ranganathan, Dalhberg e Guarino. Entretanto, Guarino não nos apresenta que categorias seriam estas; somente aponta para a necessidade de se classificar um domínio em categorias. (p.28)

No que diz respeito à teoria da terminologia, o maior nível de agrupamento de conceitos é o que ela denomina sistema de conceitos, que possui um significado próprio, pois, aqui, o sistema de conceitos representa uma classe de conceitos, e não a reunião de todas as classes, que só seria possível se existisse um elemento agregador que, no caso, podem ser as categorias. Isto acaba não acontecendo, porque a teoria da terminologia utiliza um método indutivo partindo de cadeias ascendentes para a definição do conceito, e o contexto é relevante somente para a definição do conceito, não para possibilitar uma representação do domínio. (p.28)

[...] é importante verificar um dado tipo de relação que não mais se constitui entre conceitos, mas entre a forma de expressar os conceitos, ou seja, dá-se no âmbito da língua: a chamada relação de equivalência. Esta relação é somente representada na teoria do conceito e da terminologia. (p.30)

[...] na teoria da classificação facetada, Ranganathan (1967) cita a questão da linguagem em um plano que ele denomina verbal, ou seja, está no âmbito da linguagem/comunicação, e não da representação conceitual, estando em um plano que ele denomina das idéias e, por isso, não se coloca. [...] o que se 
deseja é a representação de um contexto de atividade, e não estabelecer meios de comunicação entre "grupos de falantes", como é o objetivo da teoria da terminologia. (p.31)

h) Artigo 11: o principal enfoque do artigo são as relações, estruturas e sistemas de conceitos. Apresenta uma análise sobre as relações entre a Teoria da classificação facetada de Ranganathan, a Teoria do conceito de Dalhberg e a Terminologia.

Uma pesquisa na área de representação e recuperação de informação (CAMPOS, 1994), mostrou a existência de princípios comuns entre aspectos teóricos de instrumentos como esses, que têm por base a Teoria da Classificação Facetada, a Teoria do Conceito e a Teoria Geral da Terminologia, para a formação de estruturas sistemáticas, pois os conceitos de uma área de conhecimento se encontram relacionados entre si. Estes princípios são constituídos por elementos que estão na base da formação de tal estrutura, que são os conceitos, a relações entre os conceitos e a própria apresentação do sistema de conceitos. (p.1)

[...] a literatura vem mostrando é que a classificação está na base das três teorias. (p.1)

Uma das áreas que tem relação estreita com a classificação é a terminologia. Wüster (1981, p. 106), autor da Teoria Geral da Terminologia, observa a "semelhança das tarefas realizadas na elaboração de um tesauro e na normalização terminológica em geral" e reconhece que deveria existir maior intercâmbio entre as áreas. Em outro trabalho (Wüster, 1971), aborda as diferenças entre os sistemas de conceitos e as tabelas de classificação, enfatizando inclusive o que possuem de semelhante. Ele analisa as tabelas de classificação à luz da Teoria Geral da Terminologia. Em ambos os trabalhos, recomenda maior aproximação entre documentalistas e terminólogos. (p.2)

Dahlberg (1993, p. 225), estudiosa da área da filosofia, estabelece relações não mais entre uma teoria e um instrumento, mas entre a Teoria da Classificação Facetada e a Teoria do Conceito, por ela desenvolvida. A Teoria do Conceito apresenta princípios que podem auxiliar na determinação do conceito e de suas relações, seja para elaborar tabelas de classificação, seja para elaborar tesauros (Dahlberg, 1978). (p.2)

A lingüística foi utilizada como base para o estabelecimento de palavras compostas em sistemas de recuperação (Jones, 1981, p. 54). Porém a utilização dos pressupostos teóricos da lingüística na formação das palavras compostas no interior dos tesauros não tem conseguido resolver o problema deste tipo de descritor, pois as soluções ficam apenas no plano da língua e não da representação de conceitos. (p.3)

[...] o termo necessita de um tratamento terminológico e não lingüístico [...]. (p.3)

i) Artigo 12: com enfoque nos tesauros conceituais, analisa aspectos das relações entre conceitos. Fundamenta-se na Teoria da classificação facetada de Ranganathan e na Teoria do conceito de Dahlberg. Descreve a influência dos "analíticos” sobre Dahlberg, sendo feito o mesmo com o método analítico-sintético de Ranganathan. Descreve as categorias conceituais em Ranganathan e Dahlberg.

Tesauro conceitual seria, então, um tesauro com base em conceitos: seu nome indica que cada termo denota um conceito, ou seja, uma unidade de conhecimento. (p.349)

A definição construída para cada termo/conceito torna explícito o conteúdo do conceito e fornece os elementos para o relacionamento entre os termos/conceitos. (p.349-350)

O conceito é, de fato, o ponto de partida para estabelecer as relações conceituais e determinar a forma verbal mais adequada para representá-lo. O conceito é entendido como unidade de conhecimento, como propõe Dahlberg (1978), incluindo a definição como elemento essencial para a fixação do conceito. (p.350) 
Dahlberg afirma que o conceito se estabelece quando três elementos estão presentes: o referentelobjeto, suas propriedades e um termo que o sintetize, ou seja, que carregue com ele todas as propriedades do referente. (p.354)

Influenciada pelos analíticos, [Dahlberg] desenvolve sua teoria que fornece bases seguras para estruturar as hierarquias (relações lógicas). (p.354)

Posteriormente, tendo tomado conhecimento do método analítico-sintético de Ranganathan, incorpora o princípio de categorização como uma solução para a organização dos conceitos num sistema de conceitos, não importando a finalidade de aplicação e propõe princípios para o estabelecimento de relacionamentos associativos. (DAHLBERG, 1978a). Seu método leva à elaboração da definição analítica ou conceitual. (p.354)

j) Artigo 13: discute as relações entre conceitos e os sistemas conceituais, tendo como pano de fundo a classificação facetada de Ranganathan.

Nos Prolegomena (Ranganathan, 1967, p. 80) ele discute o processo de formação de conceitos e sua relação com o que denomina universo das idéias ou do conhecimento e sua influência no trabalho da classificação. (p.152)

Segundo Ranganathan, o homem deposita na memória perceptos puros, isto é, impressões produzidas por qualquer entidade através de um sentido primário simples. (p.152)

As entidades correlatas de um percepto, que estão fora da mente, são denominadas por Ranganathan de percepção. Quando a impressão é depositada na memória, como resultado da associação de dois ou mais perceptos puros, formados simultaneamente ou numa sucessão rápida, não temos mais somente um percepto puro, mas um percepto composto [...]. (p.152-153)

No momento em que são depositados na memória os perceptos puros e compostos, dá-se uma associação e os conceitos se formam. (p.153)

Ranganathan (1967, p. 80) alerta para o fato de que a linha divisória entre um percepto composto aquele formado pela aglutinação de vários perceptos puros - e o conceito é tênue. (p.153)

[...] é a partir da formação dos conceitos que se produzirá na mente do ser humano um quadro de identidade com o mundo que o cerca. (p.153)

Em um momento posterior à formação dos conceitos, isto é, a partir da existência de um padrão conceitual já estabelecido, pode ocorrer a assimilação de novas experiências, o que leva ao processo que Ranganathan denomina de apercepção. O conjunto dessas apercepções depositadas na memória se dá, então, a partir dos conceitos já presentes na memória, com o acréscimo da assimilação de perceptos recentemente recebidos e conceitos recentemente formados. (p.153)

Ranganthan elabora uma série de princípios que visam a permitir que os conceitos de um domínio de saber possam ser estruturados de forma sistêmica, isto é, os conceitos se organizam em renques e cadeias, essas estruturadas em classes abrangentes, que são as facetas, e estas últimas dentro de uma dada categoria fundamental. A reunião de todas as categorias forma um sistema de conceitos de uma dada área de assunto e cada conceito no interior da categoria é também a manifestação dessa categoria. (p.158)

A representação da árvore Baniana apresentada por Ranganathan vem ao encontro do conceito de rizoma de Deleuze e Guattari, (Deleuze \& Guattari, 1995), confirmando, mais uma vez, a originalidade do pensamento de Ranganathan. (p.159)

[...] Ranganathan resgata da Antiguidade Clássica, através de Aristóteles, para o universo da documentação, o conceito de categoria como um princípio fundamental para a organização do conhecimento. (p.159)

k) Artigo 13: enfoca a construção de hiperdocumentos e hipertexto, com base na teoria da classificação facetada de Ranganathan e na teoria do conceito de Dahlberg. 
O hipertexto, neste contexto, será definido como um novo veículo textual que se caracteriza como uma inscrição que possibilita uma maior aproximação entre o ato de organizar temáticamente uma idéialquestão e o ato da escrita, pois a escrita hipertextual, como toda produção textual, se realiza através de associação de conceitos interligados formando uma rede de conceitos. Além disso, o hipertexto é o primeiro suporte de escrita que potencializa uma escrita em rede. (p.3).

A estrutura do hiperdocumento consiste, então, em estabelecer as unidades conceituais/os nós e ligações entre eles de sorte a garantir consistência do documento como um todo. Em certa medida, os hiperdocumentos podem ser comparados a um sistema de conceitos, pois são nós conceituais ligados a outros nós através de um dado nível de relação Acoplado ao "ser hipertextual" existe uma ação classificatória: as ligações entre os nós são implantadas a partir de uma rede de associações. (p.6-7)

Para estabelecer nós mutuamente exclusivos, a Teoria de Classificação Facetada de Ranganathan fornece os princípios básicos para as relações lógicas. (p.7)

Sendo cada nó uma unidade conceitual, encontram-se na Teoria do Conceito os elementos que norteiam o desenvolvimento daquele fragmento de texto. (p.7)

[...] aplicar a categorização é analisar o domínio a partir de recortes conceituais que permitem determinar a identidade dos conceitos (categorias) que fazem parte deste domínio. Em um hiperdocumento, a categorização além de possibilitar a determinação da forma como a temática do documento será "recortada", ou seja, classificada para formar um todo coerente; serve também, para auxiliar na elaboração do conteúdo do nó conceitual. (p.8)

A Teoria do Conceito possibilitou uma base mais sólida para a determinação e o entendimento do que consideramos conceito, para fins de representação/recuperação da informação. Dahlberg desenvolve esta Teoria nos anos 70, visando adotar princípios para a elaboração de terminologias no âmbito das Ciências Sociais (Dahlberg, 1978). (p.9)

No hiperdocumento um nó conceitual se caracteriza por ser uma unidade de conhecimento - o conceito (Dahlberg) que corresponde à menor unidade de informação da temática a ser tratada, e é considerado o elemento que permite ao leitor traçar seu caminho de leitura. (p.9)

Para garantir uma certa univocidade entre a etiqueta lingüística empregada e o conteúdo comunicado, é necessário seguir o princípio de univocidade relativa apresentado na Teoria do Conceito e que teve origem na Teoria da Terminologia de Wuester (Wuester, 1981). O principio evidencia que para cada etiqueta lingüística, ou seja, a forma verbal, devemos ter somente um conteúdo significativo em um dado domínio representando um referente no mundo fenomenal. (p.9-10)

[...] o nó conceitual é definido como um conceito geral (Teoria do Conceito) que é representante de uma classe de conceito. Assim, ao se definir a abrangência de conteúdo a ser tratado em um nó conceitual, deve-se primeiro esgotar todos os elementos que permitem o entendimento do que é o conceito e quais são os seus elementos constitutivos. No caso do hiperdocumento, um nó deve ser trabalhado desta forma, como um todo coeso, para que depois possa dele se fazer diversos usos. Esses elementos apresentam-se na definição conceitual, elaborada por Dahlberg na Teoria do Conceito. (p.10)

\section{1) Artigo 15: o foco do artigo são as taxonomias e a teoria da classificação facetada.}

[...] taxonomia nos sistemas de informação considera a unidade sistemática (taxon) não mais família, gênero, espécie, mas conceitos. (p.3)

[...] deve-se considerar que todos esses instrumentos [Tesauros e Tabelas de Classificação Bibliográfica] que possibilitam a formação de redes de conceitos estruturados possuem como base uma estrutura classificatória que deve se apoiar em princípios da lógica. (p.4)

A taxonomia com princípio classificatório policotômico, independente da área de conhecimento ser disciplinar ou multidisciplinar, possibilita uma organização que representa classes de conceitos com um princípio de divisão (coisas e seus tipos, processos e seus tipos) [...]. (p.5)

Esta forma classificatória se baseia no princípio de categorias conceituais. (p.5)

A Categorização é um processo que requer pensar o domínio de forma dedutiva, ou seja, determinar as classes de maior abrangência dentro da temática escolhida. [...] aplicar a categorização é analisar o 
domínio a partir de recortes conceituais que permitem determinar a identidade dos conceitos (categorias) que fazem parte deste domínio. (p.5)

Quem primeiro introduziu a noção de Categoria nos sistemas de classificação foi Ranganathan (1967) [...]. (p.5)

O método de Categorização é, sobretudo, um método para organizar o pensamento, o raciocínio. (p.6)

Estes princípios foram desenvolvidos e explicitados por Ranganthan em pelo menos três de seus trabalhos, ou seja, Philosophy of library classification. (Ranganthan, 1951); Colon Classification. (Ranganthan, 1963); Prolegomena to Library Classification (Ranganthan, 1967), e constituíram o que ele denominou de Canônes para o trabalho no plano das idéias. (p.6-7).

O plano das idéias é o espaço onde os conceitos de um dado domínio são organizados formando um sistema de conceitos [...]. (p.7)

No interior de cada categoria os conceitos devem ser organizados em classes. As classes de conceitos são de dois tipos, a saber: cadeias e renques. (p.7)

Cadeias são séries verticais de conceitos que podem ser genéricas e partitivas. (p.7)

Renques são séries horizontais de conceitos e podem também ser genéricos ou partitivos. (p.7)

m) Artigo 16: com objetivos operacionais, o artigo relaciona, no âmbito da modelagem

conceitual, a ontologia de Guarino, a Teoria da classificação facetada de Ranganathan, a

Teoria do conceito de Dahlberg e a Teoria geral da terminologia de Wüster. Cita as

fontes filosóficas da Teoria do conceito de Dahlberg sem, no entanto, discuti-las.

[...] os hipertextos podem ser comparados a um sistema de conceitos, pois são nós conceituais ligados a outros nós por intermédio de relacionamentos. (p.7)

Acoplada ao "ser hipertextual", existe uma ação classificatória: as ligações entre os nós são implementadas a partir de uma rede de associações de classes. (p.7)

Na elaboração de um hipertexto, são colocados, de forma geral, quatro momentos: modelagem conceitual, modelagem de navegação, projeto abstrato de interface e implementação. [...] interessa-nos pensar o documento hipertextual em seu momento primeiro [...]. (p.7)

Nesta perspectiva, foram investigados os princípios da orientação a objetos (Rumbaugh et alii, 1994), base teórica aplicada na metodologia OOHDM. Analisou-se também uma nova disciplina que vem surgindo na área da ciência da computação que repensa as possibilidades representacionais e de organização do conhecimento como modelos de representação de domínios de conhecimento - a Ontologia (Guarino, 1994, 1998, 1998a; Gruber, 1993). Além disso, buscaram-se teorias no âmbito da ciência da informação, mas especificamente aquelas ligadas à representação de sistemas de conceitos, como a Teoria da Classificação Facetada (Ranganathan, 1951, 1967) e a Teoria do Conceito (Dahlberg, 1978, 1978a), que possibilitam a representação de domínios de conhecimento e aplicação. Foram investigados ainda os princípios estabelecidos pela Teoria da Terminologia (Wuester, 1981)) para a determinação de conceitos e suas relações. A partir da análise dos modelos e das teorias, é possível repensar os mecanismos que possibilitam a representação de uma temática, não mais de forma linear, mas de forma fragmentada e associativa, porém garantindo coerência entre os conceitos e conseqüentemente coerência entre os nós de um hipertexto. (p.9-10)

As teorias e metodologias desenvolvidas tanto no escopo temático da ciência da informação, da terminologia e da ciência da computação que estão voltadas para a representação de conhecimento apresentam, de forma mais ou menos abrangente, discussões sobre princípios, como contexto de conhecimento, natureza dos conceitos, relações entre conceitos e sistema de conceitos. (p.10)

Segundo Morin (2000, p.24), toda organização de conhecimento é realizada em função de princípios e regras em que esta organização "comporta operações de ligação (conjunção, inclusão, implicação) e de separação (diferenciação, oposição, seleção, exclusão). O processo é circular, passando da separação à ligação e, além disso, da análise à síntese. Ou seja, o conhecimento comporta, ao mesmo tempo, separação e ligação, análise e síntese. (p.10)

Entendemos a organização de conhecimento dentro de domínios nesta perspectiva sistêmica. (p.10) 
A Teoria da Classificação Facetada (Ranganathan, 1951) é representante de um modelo que se utiliza do método dedutivo para classificar o conhecimento dentro de um contexto. [...] possui mecanismos de representação para trabalhar com metaníveis conceituais, como, por exemplo, as categorias. (p.10)

A ontologia formal (Guarino, 1998a), por sua vez, apesar de possuir princípios para descrição de metaníveis de objetos em um domínio (universais), não utiliza esta classificação como mecanismo inicial para a organização dos objetos em um contexto. [...] as ontologias, em sua maioria, utilizam-se de um método indutivo para a classificação de um domínio, assim como a orientação a objetos. (p.10)

A Teoria da Terminologia (Wuester, 1981) pode também ser vista como aquela que suporta o método indutivo para pensar um dado contexto. [...] os conceitos (objeto/entidade/instância) associam-se entre si formando um sistema de conceitos. [...] o sistema é formado a partir da análise do próprio conceito, e não do contexto em que está inserido. [...] Na terminologia, categorias ou universais não são considerados. (p.10)

A Teoria do Conceito (Dahlberg, 1978), por sua vez, introduz uma metodologia que pode ser considerada como híbrida. Agrega tanto o método dedutivo quanto o método indutivo, em um exercício de pensar o particular como um todo e o todo possuindo particulares. (p.10)

Dahlberg, no estabelecimento de sua teoria do conceito, apresenta categorias para representar contextos e, em seguida, analisa os conceitos de um contexto na perspectiva de ordená-los no interior dessas categorias. A princípio, sabe-se da existência das categorias (universais), entretanto as categorias só são identificadas a partir de um processo indutivo de análise do conceito. (p.10-11)

Em uma proposta sistêmica, que leva em conta tanto os princípios de modelização de Le Moigne (1977), quanto a questão da complexidade de Edgar Morin (1990), bem como uma nova perspectiva metodológica de Latour (Latour, 1996), tais métodos não são possíveis de serem pensados de forma separada, e sim de forma sistêmica, com o indutivo e o dedutivo, a análise e a síntese vistos como processos não disjuntos, mas como processos que se complementam em um todo, ou seja, “análisesínteseanálisesíntese...”. (p.11)

Dahlberg constrói sua teoria a partir de trabalhos que realiza no âmbito da classificação bibliográfica e da terminologia, reunindo assim os aspectos importantes destas duas áreas. Da classificação bibliográfica, agrega os conhecimentos apresentados por Ranganathan sobre o universo de conhecimento e suas categorias fundamentais. Na verdade, tendo Dahlberg formação em filosofia, identifica a opção teórica de Ranganathan, que, mesmo sem estar explícito em seus trabalhos, bebe da fonte onde Aristóteles elabora sua filosofia. Da terminologia retira e transforma de maneira bastante clara os princípios para a elaboração das relações entre conceitos, tornando-as mais inteligíveis para aqueles que não tiveram a chance de serem iniciados. (p.13)

n) Artigo 17: apresenta como foco principal a análise da Teoria da classificação facetada de Ranganathan e a modelagem conceitual. Tem perspectiva operacional e de aplicação.

Em termos da modelagem conceitual, a análise facetada é uma importante técnica de construção de árvores de conceitos ou taxonomias, através de decomposição de classes elementares e facetas, formadoras de grupos homogêneos de indivíduos. A classificação facetada constitui-se, então, em instrumento auxiliar de representação de conceitos ideais em sistemas de hipertexto. (p.40)

Ranganathan, o CRG e Spiteri, em seus modelos de Análise Facetada, procuraram sistematizar o processo lógico da distinção e elaboração de conceitos e seus relacionamentos. É de se esperar, portanto, que muitos de seus cânones, princípios e postulados nos parecem derivados do simples bomsenso, e daí, sua aplicação muitas vezes intuitiva por profissionais de outras áreas, não conhecedores dos modelos teóricos.

O mérito de tais autores concentra-se na ordenação e, já afirmada, sistematização de tais processos lógicos, além das sugestões metódicas quando da inaplicabilidade de respostas simplesmente dedutivas. (p.49)

o) Artigo 19: direcionando-se, especificamente, para a análise da norma ISO 2788, da 
Teoria do conceito e da Teoria geral da terminologia, procura discutir a idéia de padronização de discursos para operacionalização. Analisa a norma ISO 2788 a partir das teorias de Dahlberg e Wüster. Aborda as relações lógicas, ontológicas e os sistemas de conceitos. Apresenta críticas às lacunas deixadas pela ISO 2788 em suas definições e questiona a não definição do termo conceito na norma.

Trabalhar com a palavra (extraída da linguagem natural, tout court) parece não ser a solução. É aqui que surgem as contribuições da Terminologia (WUESTER, 1981; FELBER, 1984) e da Teoria do Conceito (DAHLBERG, 1978): a unidade do tesauro não deve ser a palavra, mas o conceito, materializado no termo. O conceito é visto, dessa forma, como uma unidade indivisível formada pelo referente, característica e forma verbal. (p.4)

Se a palavra tem seu significado evidenciado no contexto frasal, o termo, por seu turno, carrega consigo o significado/conteúdo. O termo assim é constituído por uma forma verbal e um conteúdo conceitual. A homonímia fica, em geral, eliminada, nos tesauros, porque estes cobrem domínios específicos do conhecimento e é no contexto do domínio que o termo evoca, para a comunidade do domínio, o conteúdo que tem que evocar. Um postulado da Teoria da Terminologia é que os termos guardam uma monorreferencialidade relativa. (p.4)

Qual a contribuição da Terminologia para o Tesauro documentário? Ela se ocupa do conceito e das relações entre eles, exatamente como deve ocorrer num tesauro documentário. Outro postulado da Terminologia é que os conceitos se relacionam como um sistema, ou seja, eles se definem uns em relação aos outros. Fica difícil apreender um conceito isoladamente, pois ele precisa de outros conceitos para poder ser apreendido. Por exemplo, como dominar o conceito de 'verniz', sem ter o conceito de 'resina'? Para dominar ambos os conceitos precisamos dominar as características de cada um dos objetos a que eles se referem, as quais são, por sua vez, também conceitos. (p.4-5)

Aqui incorporamos, como apresentado anteriormente, elementos da Teoria do Conceito de Dahlberg, que considera o conceito como constituído de três elementos: o objeto/o referente, as características desse objeto/referente e a forma verbal que designa esse objeto/referente. O conceito não prescinde destes três elementos: faltando um deles não se tem o conceito, tem-se uma 'idéia' mais ou menos vaga. (p.5)

A versão anterior da Norma ISO 704 (Princípios de Terminologia), definia 'conceito' como 'unidade de pensamento'. (p.5)

Durante a reunião da ISO-TC 37, em que se aprovaria a nova versão da Norma, foi possível aprovar a definição de conceito como 'unidade de conhecimento'. (p.5)

O termo é a síntese, pois 'carrega' em si as características do objeto/referente. De acordo com a norma ISO 1087 - Vocabulário da Terminologia, 'termo' é definido como 'designação de um conceito definido numa língua especializada, por uma expressão lingüística.' [...] Esse par Conceito-Denominação constitui o Termo. (p.5)

[...] se o 'conceito' é uma unidade, então é indivisível. Se o termo denota o conceito, então não existe termo composto, pois isso equivaleria dizer que um termo composto tem um conceito composto, o que não faz sentido. Então, afirmamos, no que respeita à forma, que o termo é constituído por uma palavra ou por um grupo de palavras. E não se pode, portanto, considerar o conceito de 'termo composto'. (p.6)

A forma como abordamos cada definiçãolexplicação apresentada, se consolida, também, por uma postura teórica e metodológica. Desta forma, cabe ressaltar uma das propostas da Teoria Geral da Terminologia, no que se refere a elaboração de definições: "A característica que constitui um conceito é também um conceito. Através dela pode-se comparar conceitos, classificá-los em um sistema de conceitos, sintetizá-los através da definição, e denominá-los através dos termos. $O$ agregado das características que constituem o conceito determina sua intensão. A partir da determinação da intensão do conceito, ou seja da delimitação de suas características, é possível determinar também conceitos que possam ser relacionados ao conceito em análise por possuirem características semelhantes; em outras palavras, é possível determinar a totalidade ou o número de conceitos que este conceito abarca, o que constitui sua extensão". (FELBER, 1984, p. 58). (p.6)

[...] a falta de uma definição ou explicação do que seja 'conceito' leva a Norma a desconsiderar tal 
classificação e a fazer uma abordagem lingüística do termo, ao incluir um capítulo sobre a forma verbal, fornecendo orientação sobre o uso de substantivos, adjetivos, advérbios e verbos e, ainda, sobre o uso de singular e plural. (p.10)

A adoção da Teoria do Conceito e da Teoria da Terminologia, como fundamentos para a elaboração de tesauros documentários fornecem as condições para se construir instrumentos de trabalho consistentes, porque a análise tem início no conceito. Como se pôde perceber, na Norma 2877 a análise tem início na expressão verbal. (p.14)

p) Artigo 25: tendo como objetivo discutir a aplicação da modelagem conceitual a sistemas de hipertexto, tem seu principal foco na análise facetada de Ranganathan. Apresenta uma revisão sobre a Teoria da classificação facetada de Ranganathan.

Como a classificação facetada, os sistemas de hipertexto também objetivam a estruturação do conhecimento, através da organização dos conceitos e das relações entre eles, permitindo o mapeamento de uma área de assunto e a inclusão de novos conceitos [...]. (p.31)

Shiyali Ramamrita Ranganathan (1892-1972), matemático indiano que tornou-se bibliotecário, foi um dos estudiosos que mais contribuiu para a teoria da biblioteconomia no século XX, especialmente na área da classificação de assunto. Seu sistema de Classificação de Dois Pontos (Colon Classification, 1933), surgiu de sua insatisfação com os sistemas de Classificação Decimal de Dewey (CDD) e Classificação Decimal Universal (CDU). Depois de constatar, em cinco periódicos diferentes, que a maioria dos assuntos tratados eram assuntos compostos, Ranganathan elaborou sua Classificação de Dois Pontos, também conhecida como Classificação em Facetas ou Classificação Analítico-Sintética. Criou um sistema quase matemático, estruturando o conhecimento de maneira que os assuntos compostos, sinteticamente, surgiam a partir de conceitos “elementares”. (p.32)

Entre os princípios introduzidos por Ranganathan, o mais conhecido é o princípio de análise de faceta (subdivisões de assuntos em suas partes componentes) e a síntese (recombinação destas partes para classificar um documento adequadamente). Na sua Classificação Facetada, Ranganathan identificou cinco categorias: Personalidade (P), Material (M), Energia (E), Espaço (S) e Tempo (T), mnemonicamente conhecido como PMEST. (p.32)

[...] a teoria de análise de faceta e síntese, proposta por Ranganathan, transformou-se em uma importante base teórica para a área de análise de assunto no século XX [...]. (p.32)

Ranganathan mostrou que a relação entre assuntos, feita através do símbolo de dois pontos, pode ser infinita, provando que o conhecimento pode ser multidimensional e que essas relações podem tomar rumos diferentes, dependendo da síntese entre vários conceitos múltiplos (VICKERY, 1980, p.209). (p.32)

Para elaborar uma classificação facetada, examina-se a literatura do assunto a fim de identificar seus conceitos e termos, estabelecendo-se suas características e facetas. Após levantar e definir a terminologia do assunto, os termos são analisados e distribuídos em facetas. Como já foi definido, faceta é a coleção de termos que apresentam igual relacionamento com o assunto global, refletindo a aplicação de um princípio básico de divisão. As facetas obtidas são inerentes ao assunto e dentro de cada faceta, os termos que as constituem são sucetíveis a novos agrupamentos, pela aplicação de outras características divisionais, dando origem às subfacetas. Os termos, nas subfacetas, são mutuamente exclusivos, isto é, não devem se sobrepôr na formação de assuntos compostos. Estabelecidas as facetas e subfacetas, é importante determinar a ordem de citação em que serão apresentadas no sistema de classificação. A seguir, ordenam-se todos os elementos em ordem de arquivamento, o que permite colocar o assunto geral antes do específico. Após estas etapas, o sistema está pronto para receber uma notação, que deverá ser flexível para permitir a inclusão de novas classes. Finalmente, compila-se um índice com todos os termos e suas respectivas notações (PIEDADE, 1983; BARBOSA,1972). (p.32)

q) Artigo 26: tem foco na Teoria da classificação facetada de Ranganathan para modelagem conceitual em sistemas de hipertexto. 
Desde o final da década de 1980, diversos pesquisadores começaram a estudar a possibilidade de se utilizarem as teorias da classificação na organização conceitual de sistemas de hipertexto, principalmente a classificação facetada, criada pelo indiano Ranganathan. (p.189)

Shiyali Ramamrita RANGANATHAN (1892-1972), matemático indiano que tornou-se bibliotecário, foi um dos estudiosos que mais contribuiu para a teoria da biblioteconomia no século $X X$, especialmente na área da classificação de assunto. Sua insatisfação com os sistemas de Classificação Decimal de Dewey (CDD) e Classificação Decimal Universal (CDU) o levou a buscar um sistema mais eficiente. Depois de constatar, em cinco periódicos diferentes, que a maioria dos assuntos tratados eram assuntos compostos, Ranganathan organizou, em 1933, sua Classificação de Dois Pontos (Colon Classification), também conhecida como Classificação em Facetas ou Classificação Analítico-Sintética. Sob influência de sua área inicial, a matemática, estruturou o conhecimento de maneira que os assuntos compostos, sinteticamente, surgiam a partir de conceitos elementares. (p.190)

A análise facetada reconhece muitos aspectos em um único assunto, e tenta sintetizá-los de maneira que os descreva de forma mais adequada. Esse fato é relevante para a abordagem não linear do hipertexto, porque permite ao usuário ver um assunto sob diferentes perspectivas, possibilitando um reagrupamento de um mesmo conhecimento como parte do todo, ao invés de estar subordinado dentro de uma hierarquia. Essa modelagem conceitual é uma etapa importante na organização da informação para sistemas de hipertexto. (p.191)

r) Artigo 27: o enfoque são os mapas conceituais para aplicação em hipertexto.

Apresenta uma revisão sobre os mapas conceituais e suas relações com aspectos cognitivos.

[...] mapa conceitual é uma representação que descreve a relação das idéias do pensamento, relação esta pré-adquirida ao longo do processo de aprendizagem na construção do conhecimento, que vai sendo arquivada na memória. (p.135)

Joseph D. Novak (1984, p.1), da Cornell University, desenvolveu a teoria do mapa conceitual em 1984 como uma forma de organizar e representar o conhecimento, a partir da teoria da aprendizagem significativa, esta desenvolvida na psicologia educacional por David Ausubel (AUSUBEL, 1963; AUSUBEL, 1968; AUSUBEL, NOVAK e HANESIAN, 1978). (p.136)

Essa teoria parte do pressuposto de que o armazenamento de informações ocorre a partir da organização de conceitos de forma hierárquica [...]. (p.136)

A idéia fundamental da teoria de Ausubel é que a aprendizagem é feita por assimilação de novos conceitos. [...] A teoria da aprendizagem significativa é baseada no modelo construtivista do processo cognitivo humano, que explica como os conceitos são adquiridos e organizados dentro de um aprendizado mais baseado na cognição. (p.136)

Primeiro, os conceitos são representados de forma hierárquica, com o conceito mais geral no início do mapa e depois os mais específicos, arranjados hierarquicamente. (p.136)

A estrutura hierárquica de um campo específico do conhecimento depende, também, do contexto no qual o conhecimento é considerado. (p.136)

[...] a técnica usual de subdividir classes em subclasses, em forma de árvore, é a mesma técnica utilizada por S. R. Ranganathan para criar subgrupos pelo processo de categorização em sua teoria da análise facetada. Todo conceito, em qualquer nível na hierarquia, terá sempre um nível mais geral. As relações entre os conceitos no mapa conceitual representam as preposições, que constituem unidades semânticas por ligar dois ou mais conceitos. (p.136)

O mapa conceitual tem sido utilizado em diversas áreas do conhecimento como técnica formal ou semiformal de diagramação. Na área de educação, ciência política, lingüística e filosofia da ciência, essa técnica tem sido usada para apresentar visualmente a estrutura do conhecimento e suas formas de argumentação. (p.137)

Uma das principais funções da mente é interpretar o significado das informações adquiridas $e$ transformá-las em conhecimento, o que se torna mais fácil quando são apresentadas em formato gráfico. 
O mapa conceitual pode ser um suporte apropriado para a arquitetura de sistemas de hipertexto por possibilitar uma interface atrativa, interativa e fácil de ser utilizada, facilitando a navegação em redes semânticas. (p.137)

O mapa conceitual é uma ferramenta eficaz que pode ser adotada para desenvolver estudos dentro das ciências cognitivas. A representação do conhecimento, sob a forma de mapas conceituais, é uma alternativa de estruturar a informação, pois procuram refletir a organização da estrutura cognitiva de uma pessoa sobre determinado assunto. Essas estruturas do conhecimento são representações da organização das idéias na nossa memória semântica. (p.143)

s) Artigo 28: discute a websemântica e as ontologias. Estas últimas, com base em Guarino. Também apresenta a Teoria do conceito de Dahlberg e a Teoria da classificação facetada de Ranganathan. A modelização de Le Moigne e o pensamento sistêmico de Morin também estão presentes.

[...] as ontologias vêm sendo utilizadas em diversas áreas. Guarino (1998 a) em seu trabalho afirma que esta ontologia com "o" minúsculo, diferentemente da ontologia com " $O$ " maiúsculo, campo de estudos da Filosofia (nota), tem sido reconhecida em diversos campos de pesquisa, tais como: engenharia do conhecimento, análise orientada a objeto, recuperação e extração de informação, organização $e$ gerência de conhecimento, projeto de sistemas baseados em agentes, projeto de banco de dados, entre outros. (p.111)

Barry Smith (2002), discutindo a relação entre Ciência e Ontologia (enquanto domínio de conhecimento preocupado com a natureza dos seres), afirma que enquanto o papel da ciência é "explicar" a natureza, o papel da Ontologia seria vir a seguir para descrever, organizar e sistematizar o conhecimento obtido pelas descobertas científicas. Este parece ser um lugar a ser ocupado também pela Ciência da Informação, vinda de uma longa tradição de organização de domínios de conhecimento, aplicada originalmente à organização de repertórios documentais. (p.111)

Definições com origem na Ciência da Informação, mais ligadas ao foco do uso das ontologias na Web Semântica, são as seguintes:

Ontologia é definida como uma especificação formal e explícita de um conceitualização compartilhada. Fornece uma compreensão comum e compartilhada de um domínio que pode ser comunicada a pessoas e sistemas (DING, 2002b, p. 375).

Uma conceitualização parcial de um domínio de conhecimento, compartilhada por uma comunidade de usuários, definida em linguagem formal, processável por máquina, para o objetivo explícito de compartilhar informação semântica entre sistemas automatizados. (JACOB, 2003, p. 20).

Nestas definições se destacam as noções de "conceitualização", "compartilhada”, num determinado “domínio" e de representação "formal”, “processável por programas”. (p.111)

Uma conceituação é uma abstração, uma visão simplificada do mundo que se representa para satisfazer um ou mais dos seguintes propósitos: "permitir que múltiplos agentes compartilhem seu conhecimento; ajudar as pessoas a compreender melhor certa área de conhecimento; ajudar pessoas a atingir um consenso no seu entendimento sobre uma área de conhecimento" (SMITH, apud FALBO, 1998). (p.111112)

Em Lógica, uma conceituação identifica o objeto e relações que existem no universo lógico. (WEINSTEIN, 1998). (p.112)

A literatura, muitas vezes, vem denominando ontologias pequenas estruturas de conceitos. Essas estruturas, apesar de possuírem conceitos e relações, não possuem definição na forma de axiomas dos seus conceitos e, na maioria das vezes, não são árvores, mas grafos. Estes tipos de ontologias são chamadas, também, de ontologias informais (WEINSTEIN, 1998) ou ontologias lingüísticas (GUARINO, 1998 b). (p.112)

A diferença entre uma ontologia lingüística e uma formal é que as ontologias lingüísticas constroem redes semânticas entre palavras, onde estão em jogo cadeias de associações que, na maioria dos casos, não estão baseadas em relações lógicas. (p.112)

Uma ontologia formal por sua vez elabora redes conceituais com relações que formam cadeias lógicas e ônticas como, por exemplo, as relações de generalização e agregação respectivamente. (p.112) 
Uma ontologia define um vocabulário comum para uma comunidade que precisa compartilhar informação em um determinado domínio. Inclui definições de conceitos básicos no domínio e as relações entre estes de forma que sejam interpretáveis por máquina. (p.121)

No entanto, apesar de propostas de linguagens e ferramentas de representação e construção de ontologias no domínio Ciência da Computação, estas propostas, em geral, ainda não contemplam diretrizes satisfatórias de identificação dos conceitos e relacionamentos entre estes, de criação de definições consistentes, nem tampouco de modelização de domínios associados. (p.121)

Ao longo de sua trajetória, a Ciência da Informação desenvolveu um arcabouço teórico e metodológico consubstanciado em obras como as de Otlet (1989), Ranganathan (1967), Dahlberg (1978a), Hjфrland (2002) e do CRG - Classification Research Group (WILSON, 1972), entre outros, que potencialmente têm grande aplicabilidade no desenvolvimento de ontologias. (CAMPOS, 2005). (p.122)

Neste estudo vamos abordar as questões relacionadas à modelização de domínios, que no âmbito das ontologias, são representadas por taxonomias, que formam a sua espinha dorsal, como citado por Guarino - 'Toda ontologia formal está pautada em uma taxionomia, como uma "espinha dorsal" de qualquer domínio de conhecimento'. (GUARINO, 1998 a). (p.122)

[...] os elementos que formam as ontologias, conceitos e seus relacionamentos devem ser agregados de forma consistente formando um sistema de conceitos, onde as partes estão relacionadas de tal forma, que são vista de forma sistêmica.

Entretanto, é importante acrescentar que uma ontologia é mais que um vocabulário controlado ou ainda que um tesauro. Conforme explicitaram Campos e colegas (2005):

Muita confusão se tem feito em torno do conceito de ontologia, que não pode ser considerado somente como um vocabulário controlado. Uma ontologia possui informações de natureza distinta, ou seja: terminológica - possui um conjunto básico de conceitos e relações-; e assertivas aplicadas aos conceitos e relações, que constitui um conjunto de axiomas, diferentemente de um tesauro." (CAMPOS, M. L. M; CAMPOS, M. L. A.; CAMPOS, L. M., 2005). (p.122)

Se considerarmos uma ontologia como um sistema de conceitos interelacionados, podemos dizer que estas contém basicamente três componentes, quais sejam: 1. Um conjunto básico de conceitos e relações; 2. Uma forma de representação; 3. Um conjunto de assertivas. (p.122-123)

Entretanto, as ontologias necessitam de relações mais explicitadas para possibilitar inferências. Se para os tesauros é importante saber se entre dois termos existe uma relação de parte/todo. Nas ontologias devemos identificar que tipo de parte e de todo esses termos representam [...]. (p.123)

[...] a utilização de taxonomias permite que se estabeleçam padrões de alto nível para a ordenação e classificação de informação através do uso de mecanismos de herança. O conceito de herança é um dos conceitos mais poderosos no desenvolvimento de software. (p.124)

O modo como o núcleo temático de uma ontologia é constituído é de importância capital para a sua elaboração. Esta organização influenciará diretamente nas relações que se estabelecem entre os conceitos, e consequentemente nas definições desses conceitos e em sua estruturação no domínio. (p.124)

[...] verificam-se quatro princípios fundamentais que devem auxiliar o modelizador na elaboração de estruturas conceituais em domínios de conhecimento, como é o caso das ontologias, quais sejam: o método de raciocínio; o objeto de representação; as relações entre os objetos e as formas de representação. (p.124)

No âmbito da Ciência da Informação, por sua vez, a Teoria do Conceito (DAHLBERG, 1978b) introduz. uma metodologia que poderíamos denominar de híbrida - não só o método dedutivo e não só o método indutivo - mas agregando os dois em um exercício de pensar o particular como um todo e o todo possuindo particulares. Dahlberg, no estabelecimento de sua teoria, apresenta categorias para representar contextos e, logo depois, analisa os conceitos de um contexto na perspectiva de ordená-los no interior dessas categorias. A princípio, sabe-se da existência das categorias (universais); entretanto, chega-se a elas, a partir de um processo indutivo de análise do conceito. (p.124-125)

Numa proposta sistêmica, que leva em conta tanto os princípios de modelização de Le Moigne (1977), quanto à questão da complexidade de Edgar Morin (1990; 2000), acreditamos que tais métodos não são possíveis de serem pensados de forma separada, mas sim de forma sistêmica, onde o indutivo e o dedutivo, a análise e a síntese, são vistos como processos não disjuntos, que se complementam em um todo, ou seja, "análise-síntese-análisesíntese...". (p.125)

No âmbito da Ciência da Informação, a Teoria da Classificação (RANGANTHAN, 1967) e a Teoria do Conceito (DAHLBERG, 1978a) se apresentam como teorias que suportam um dos primeiros esforços 
teórico-metodológicos que evidenciam a questão da unidade de representação. Ranganathan em seus Prolegomena (1967) introduz o conceito de isolado como a unidade mínima e manipulativa de um sistema de classificação. Dalhberg apresenta o Conceito, como unidade mínima, e o define como uma tríade - referente, características e nome. O objeto é o referente, que pode ser classificado como objeto individual, ou geral, que, circunscrito a um dado contexto, requer apropriação de características, sendolhe designado um signo lingüístico - um nome. (p.125)

t) Artigo 31: com enfoque na discussão sobre tesauros e ontologias, analisa estas últimas com base em Aristóteles e sua influência na Teoria do conceito de Dahlberg e na Inteligência artificial. Discute as ontologias com base em Guarino, analisando a operacionalização de conceitos nas ontologias.

O entendimento da visão de Aristóteles sobre ontologia merece uma discussão mais detalhada, devido à sua grande influência, tanto na ciência da computação, quanto na ciência da informação. Na ciência da informação, esta influência se faz notar nos fundamentos teóricos da área, como, por exemplo, o uso de categorias na teoria do conceito de Dahlberg e na classificação facetada de Ranganathan. (p.6)

A Ciência da Informação estuda os métodos e técnicas para o armazenamento, organização $e$ recuperação de informação, mais tradicionalmente na forma de documentos. Para cumprir esta meta foi preciso desenvolver linguagens semi-formais, denominadas de linguagens documentárias, que auxiliam na organização do conhecimento de uma área. Sendo a organização do conhecimento uma das principais preocupações de Aristóteles é justamente no momento da construção das linguagens documentárias que sua filosofia se faz mais presente. (p.8)

[...] uma ontologia é "especificação formal e explícita de uma conceitualização compartilhada", onde formal significa que a ontologia pode ser expressa em uma linguagem formal, explícita significa que é um objeto de nível simbólico e compartilhada indica que o conhecimento é aceito dentro da comunidade. Já uma conceitualização é, segundo Gruber, "... os objetos, conceitos, e outras entidades que se assume existir em alguma área de interesse e as relações que ocorrem entre eles. Uma conceitualização é uma visão abstrata e simplificada do mundo que nós desejamos representar para algum propósito. Toda base de conhecimento, sistema baseado em conhecimento, ou agente atuando no nível do conhecimento é comprometido com alguma conceitualização, explicita ou implicitamente". (tradução dos autores) (Grubber,1993, p.1). (p.15)

Os conceitos ontológicos são: objetos, processo, particular, individual, todo, parte, evento, propriedade, qualidade, estado, etc. Já os conceitos epistemológicos são: crenças, conhecimento, conhecimento incerto, conhecimento errado, etc. (p.19)

As conclusões deste trabalho, suportadas pela análise da literatura, são as seguintes: 1) ontologia da filosofia e ontologia da CC são objetos distintos; 2) ontologia da CC e tesauro são objetos que operam no mesmo nível, ou seja, nível epistemológico; 3) ontologia e tesauro possuem propósitos distintos, sendo que a primeira é voltada para registro de conceitos de um domínio com o propósito de inferência automatizada e o segundo para comunicação entre o usuário e linguagens documentárias; 4) os tesauros cumprem parte dos objetivos que a CC pretende com o uso de ontologias e por isso são denominados de ontologias terminológicas. (p.27)

u) Artigo 32: apresenta uma análise sobre a modelagem de sistemas computacionais com base na terminologia. Analisa as definições de "termo" e de "conceito" nas normas e apresenta o triângulo de significado de Ogden e Richards. Aborda os sistemas e as relações lógicas e ontológicas dos conceitos, na perspectiva da terminologia de Wüster. 
A terminologia é uma ciência que busca determinar o termo que denota um conceito específico. A definição precisa desta relação termo-conceito é fundamental para que se possa organizar e comunicar informações e possui aplicação em diversas áreas de estudo. (p.2)

A definição constante no padrão ISO 1087-1:2000 apresenta o conceito como uma unidade de conhecimento criada por uma combinação única de características. Esta definição está de acordo com a definição proposta por Dahlberg (1978, p.143), tornando o conceito algo possível de ser capturado, uma vez que o conhecimento "pode ser considerado como a totalidade das proposições verdadeiras sobre este mundo, existindo, em geral, em documentos ou nas cabeças das pessoas”. (p.3)

Para a Terminologia, o termo é a designação verbal de um conceito geral em um domínio específico (ISO 1087, 2000) e estabelece com o conceito uma relação unívoca. Esta relação de unicidade é possível uma vez que o escopo de trabalho da terminologia abrange apenas as línguas artificiais, onde esta correspondência é garantida pelas normas. (p.3)

Os elementos participantes deste processo formam a tríade linguagem-pensamento-realidade, proposta por SAUSSURE (1987). Em 1997, SUONUUTI (2001) adicionou uma quarta dimensão ao triângulo do significado de Ogden e Richards (1923) de modo a refletir a visão da terminologia sobre a relação entre seus elementos básicos. O triângulo tomou, então, a forma de uma pirâmide e a quarta dimensão inserida representa o papel da definição. (p.3)

Ao permitir a diferenciação de um conceito de outros conceitos a definição posiciona o conceito dentro do sistema de conceitos. Esta visão denotativa do significado de um termo está de acordo com a visão da filosofia positivista, onde proposições descrevem realidades, sendo, neste caso, uma visão apropriada aos propósitos da Terminologia, uma vez que seu nicho é o das linguagens da ciência e da técnica. (p.4)

Segundo SUONUUTI (2001, p.14) “conceitos não são fenômenos independentes. Eles estão sempre relacionados a outros conceitos de uma forma ou de outra, e formam sistemas de conceitos que podem varia de muito simples a muito complexo". (p.4)

No sistema de conceitos, proposto por Wüster, as relações entre conceitos podem ser divididas em dois grandes grupos: o grupo das relações lógicas e o das relações ontológicas. Esta divisão reflete a visão de Wüster que distingue as relações que podem ser observadas nos próprios objetos individuais (ontológicas) e as relações que são estabelecidas no plano conceitual (lógicas). (p.4)

As relações lógicas se dão por abstração e baseiam-se na similaridade das características entre conceitos, ou seja, se baseiam na similaridade da intensão dos conceitos. Portanto, as relações lógicas são relações diretas entre conceitos. Uma observação importante é que sendo relações que são estabelecidas em um nível lógico, então não é o caso que elas existam na realidade. Portanto, o estabelecimento de uma relação lógica entre dois conceitos depende da conveniência e dos propósitos de quem a estabelece. Por isso é possível encontrar em um sistema de conceito para um domínio dois conceitos relacionados por um tipo de relação e em outro sistema para o mesmo domínio os mesmos conceitos ligados por outro tipo de relação. A relação de subordinação lógica ocorre quando se tem dois conceitos com as mesmas características, mas um deles tem uma característica a mais. (p.5)

As relações ontológicas são aquelas que podem ser observadas nos objetos individuais. Uma vez observada no plano dos objetos individuais, as relações são estabelecidas no plano conceitual por meio de um processo de abstração. (p.5)

[...] a diferença básica entre as relações lógicas e ontológicas é que as primeiras se dão entre conceitos e as últimas entre os objetos individuais [...]. (p.5)

[...] mesmo sem mencionar o termo explicitamente, a ciência da informação, usa a ontologia na forma como entendida pela filosofia. (p.10)

v) Artigo 33: enfocando a construção de tesauros, analisa políticas de elaboração e estruturas de tesauros. Discute a criação de tesauros para a Ciência da Informação.

O estudo dos tesauros envolve diversos campos do conhecimento, pois o tema é, em si, multidisciplinar. Como área de estudo da Ciência da Informação, multidisciplinar por natureza e interdisciplinar na vocação, o tesauro herda dessa ciência essas propriedades. Diz respeito à Ciência da Informação, por sua origem e utilização imediata nos processos de indexação e recuperação de informação; também está 
vinculado às contribuições da Terminologia, da Lingüística, da Filosofia, da Lógica, da tradução, da análise sistêmica, da normalização, dos sistemas de classificação, entre tantos outros. (p.2)

A construção de um tesauro requer uma atitude flexível para incorporar as mudanças que a linguagem utilizada sofre no caminho de seu desenvolvimento sem abrir mão dos conceitos, mas em atitude aberta a seu próprio desenvolvimento. (p.4)

A ambigüidade que as palavras trazem em seus múltiplos significados, faz com que se tornem inadequadas para a indexação e a recuperação. As linguagens de indexação partem de uma palavra, tomada sob certos princípios, ou uma expressão, para representar um único conceito ou idéia. De antemão, pressupõe-se que estes conceitos ou idéias encontram-se legitimados na comunidade de usuários para a qual se constrói o tesauro. (p.4)

Cada palavra, ou expressão recebe então o nome de termo, que equivale a um conceito adicionado de uma designação, construída por uma ou mais unidades léxicas. O controle é necessário para que se mantenha a relação de um termo para cada conceito e a cada conceito um só termo. Os termos que representam um conceito são também chamados de descritores. Os outros recebem o nome de nãodescritores e formam o conjunto das remissivas. Um tesauro é algo dinâmico, retrato fiel da realidade que representa, em contínua mudança, requerendo contínuas manutenções e atualizações. Seus componentes são: os termos, o conjunto de remissivas e a sintaxe. (p.4)

A Ciência da Informação é um campo emergente no âmbito das Ciências Sociais que se caracteriza por estudos de cunho multidisciplinar e interdisciplinar. Como resultado, a sua representação temática oscila entre as especificidades do campo e as hibridações conceituais realizadas nas fronteiras do seu domínio. A geração de um tesauro para a Ciência da Informação, como o TCI, deve levar em consideração essa particularidade, sob o risco de estabelecer uma estrutura pouco consistente e um facetamento que não reflita o seu real entrelaçamento conceitual, preocupação presente em todo o processo. (p.10)

w) Artigo 34: o foco principal do artigo é a designação terminológica.

[...] conferir um nome torna-se tarefa complexa, pois envolve mecanismos que associam às formas comunicáveis de linguagem, características conceituais ou propriedades específicas dos processos e objetos presentes na realidade social, econômica, psicológica e outras. (p.2)

[...] a designação é uma forma de fixação conceitual, cuja função é a de garantir uma comunicação eficiente, livre de ruídos e de significações incorretas ou acessórias, a ciência da terminologia dispõe de procedimentos que permitem obter, a partir da análise do conceito, sua designação apropriada, isto é, o termo. (p.2)

O conceito, uma vez determinado, fornece uma armação estrutural que permite a elaboração de definições e a escolha elou seleção dos termos apropriados para designá-lo ou denominá-lo. Entende-se por definição a descrição e a delimitação de um conceito, que permitem diferenciá-lo de outros conceitos no interesse de um sistema de conceitos. Desse modo, as características de um conceito são suas qualidades, suas propriedades, ou as relações que mantêm com outros conceitos, as quais servem de base para sua classificação, sua comparação com outros conceitos e sua definição, ou para a criação $e$ reelaboração de novos conceitos. (p.5)

De um modo geral, as características podem ser classificadas em intrínsecas ou extrínsecas. As características intrínsecas representam o objeto com suas propriedades, tais como forma, tamanho, material, cor etc. [...] As características extrínsecas referem-se ao uso ou função de objetos, sua origem, relações com outros objetos diferentes. (p.5)

x) Artigo 35: analisando a organização e representação de conceitos nas Linguagens Documentárias, o artigo aborda e aprofunda aspectos da teoria da classificação facetada de Ranganathan, a Teoria do conceito de Dahlberg e a Teoria geral da terminologia de Wüster. Estabelece relações entre a lingüística e a documentação. 
[...] a discussão de questões ligadas a princípios e métodos de organização e representação de conceitos em Linguagens Documentárias (LD) converge para o entendimento de que, mesmo com a velocidade atual das comunicações (impressas ou digitais), não é possível que os profissionais da informação, principalmente os documentalistas que estudam e trabalham com Documentação e Lingüística, fiquem à margem do contexto em que interagem e renovam suas práticas. (p.22)

Assim, a tentativa de esclarecer os fundamentos teóricos da organização e representação de conceitos para melhor compreensão da percepção dos profissionais sobre suas bases lingüísticas, sociais e culturais poderá favorecer os modos de representação do conhecimento e aperfeiçoar a práxis, pela intermediação entre pessoas(sujeitos)/usuários-clientes e processos. (p.22)

Estudos sobre modelagem de domínios de conhecimento têm se destacado na literatura como o de Campos e Campos (2003) que analisam questões teóricas/metodológicas para comparar os mecanismos de abstração presentes em teorias da Ciência da Informação, Ciência da Computação e Teoria da Terminologia. Da Ciência da Informação, analisaram as teorias da Classificação Facetada de Ranganathan e do Conceito de I. Dahlberg, voltadas mais especificamente à representação de sistemas de conceitos e que possibilitam a representação de domínios de conhecimento. Da Ciência da Computação, investigaram os modelos representacionais associados à modelagem de sistemas de bancos de dados, mais especificamente o Modelo Orientado a Objetos (Gray, 1992; Furlan, 1998; Rumbaugh, 1994) e a Ontologia Formal (Guarino, 1998, 1998 a, 1994, 1997; Gruber, 1993; Sowa, 2000), campo que repensa as possibilidades representacionais e de organização de domínios de conhecimento. Da Teoria da Terminologia de E. Wüester (1981) estudaram os princípios estabelecidos para a determinação de conceitos e suas relações. (p.23)

[...] o diálogo necessário entre a Ciência da Informação, a Ciência da Computação e a Terminologia não prescinde da identificação e compreensão dos fundamentos teóricos dos modos de organizar o conhecimento, do contexto em que se realiza a percepção humana, das bases lingüísticas, sociais e culturais e das estruturas pelas quais se realiza a representação do conhecimento. (p.24)

Essa grade interpretativa, considerada um sistema de conceitos ou unidades de conhecimento, por sua vez, denotados pelos termos e explicados pelas definições, também se relaciona a conjuntos mais abrangentes de idéias ou conceitos, denominados categorias, cuja estrutura faz parte da Teoria da Classificação e da Teoria Geral de Terminologia. Nessa estrutura destacam-se as relações lógicas (relação genérico-específica, relação analítica e relação de oposição), as relações ontológicas (relação partitiva, relação de sucessão e relação material-produto), as relações de efeito (de causalidade, instrumental e de descendência) e as relações de equivalência. Portanto, a trajetória metodológica da construção dos tesauros requer, por um lado, o reconhecimento dessa estrutura complexa de conceitos e relações e, por outro, a capacidade de controlar ou reordenar significados com base em conhecimentos lógicos e filosóficos, padrões e informações, de modo a permitir ao usuário (indexador ou pesquisador) encontrar os termos mais significativos e relevantes para representar a idéia ou o conceito procurado. (p.26)

Campos (2001), ao analisar a Teoria da Classificação Facetada (RANGANATHAN), a Teoria Geral da Terminologia (WÜESTER) e a Teoria do Conceito (DAHLBERG), consideradas as mais representativas da área, aponta seus princípios comuns, cuja síntese concede destaque aos aspectos considerados aqui esclarecedores ao profissional da informação na sua prática em AD.

Em primeiro plano, a indissociabilidade entre conceitos e termos é determinante para a compreensão do processo e do primeiro aspecto comum às três teorias, a forma de abordagem do termo, seja no esquema de classificação, no tesauro ou na terminologia.

[...] a designação de um conceito único por um termo, apresenta-se como uma exigência da terminologia e do tesauro. (p.31)

y) Artigo 37: o foco da discussão são os tesauros e as ontologias. Parte de uma pesquisa empírica, com análise de conteúdo e análise terminológica. Aborda a Teoria Comunicativa da Terminologia de Cabré, apresentando questões lingüísticas e discursivas em contextos específicos (socioterminologia). Nessa perspectiva, discute a 
função dos termos em relação aos conceitos. Aprofunda a discussão sobre o tipo de abordagem que os conceitos recebem nos tesauros e nas ontologias.

Guarino e Giaretta (1995) ressaltam que ontologia é uma teoria lógica que fornece um relato explícito e parcial de uma conceitualização, e, afirmam também que ontologia pode ser considerada sinônimo de conceitualização, ou seja, uma estrutura semântica intencional que codifica as regras implícitas, legitimando uma estrutura de uma parte da realidade. Guarino (1998) expõe que o termo 'ontologia' denota o resultado da atividade de análise conceitual que modela um domínio, realizada por meio de metodologias padrão. (p.4)

[...] com base em princípios epistemológicos focados na dimensão comunicativa das línguas naturais, a Teoria Comunicativa da Terminologia, TCT enxerga o termo como uma unidade de conhecimento, composta por uma forma e um conteúdo, sendo que a forma é a unidade lexical que denomina o conceito (conteúdo). (p.6)

Com relação ao conceito, a literatura voltada aos tesauros o considera como o conjunto formado pelas características de um objeto, que por sua vez são sintetizadas por um termo, definição pautada na Teoria do Conceito. Para os estudos de ontologias, os conceitos são unidades de um vocabulário especializado que representam classes, entidades, atributos e processos. (p.16)

[...] no âmbito dos tesauros o conceito é abordado sob uma ótica mais teórica (abstrata), como uma unidade representante de um objeto. No âmbito das ontologias, embora o conceito também seja uma unidade representante de um objeto, o conceito é tratado sob uma ótica mais aplicada. (p.16)

A área da Ciência da Informação, que predominantemente cobre os estudos de tesauros, objetiva uma investigação de cunho mais reflexivo, mapeando todo um campo teórico-conceitual em busca de embasamentos e entendimentos teóricos e metodológicos referentes a aplicações passadas e futuras. A área da Ciência da Computação, responsável pela maioria dos estudos de ontologias, não negligenciando as reflexões teóricas, mas sim, priorizando a construção dos aparatos informáticos, centra suas investigações no desenvolvimento e aplicação de seus produtos (nesse caso as ontologias). (p.16)

z) Artigo 42: com enfoque na classificação facetada e nos tesauros, o artigo apresenta uma análise da Teoria da classificação facetada de Ranganathan e da Teoria do conceito de Dahlberg. Faz uma discussão sobre o relacionamento entre o conceito na lógica e nas ontologias.

A literatura tem mostrado que a classificação está presente não apenas nos sistemas que visam à recuperação de informação, mas na base de sistemas e atividades que se ocupam da organização do conhecimento em suas diferentes manifestações, como, por exemplo, os sistemas de inteligência artificial e hipertextos, agora tão presentes quanto as tecnologias de ponta, levando os estudiosos da área a pesquisas constantes no desenvolvimento de sistemas. Assim, segundo Gomes (1996), a unidade a ser manipulada nesses sistemas e atividades é o conceito, que é a unidade de conhecimento. (p.162)

[...] a classificação é um conjunto de conceitos organizados sistematicamente de acordo com os critérios ou características escolhidas, conforme é apresentado a seguir, extraído da norma ISO TR 14177/94 Classificação da informação na indústria da construção:

a) classes de classificação: unidade de alto nível dentro de uma classificação expressando um conceito principal;

b) definição de classe: formulação das características essenciais de uma classe de classificação que desenha uma clara fronteira entre ela e outras classes de classificação;

c) tabela de classificação: apresentação estruturada de itens de classificação de uma classe de classificação;

d) item de classificação: único conceito definido, unicamente dentro de uma classe de classificação;

e) termo de classificação: designação de uma classe de classificação ou item de classificação por meio de uma expressão lingüística; 
f) notação: um identificador alfanumérico. Trata-se de um sistema de códigos expressando o arranjo de uma classificação. (p.163-164)

O uso de categorias na organização de conceitos e, em conseqüência, na elaboração de uma classificação é um recurso para o entendimento da natureza do conceito e para a formação das estruturas conceituais. As categorias possibilitam a sistematização do conhecimento. (p.165)

Campos (1994), em uma pesquisa na área de representação e recuperação da informação, mostrou a existência de princípios comuns entre aspectos teóricos de instrumentos como os sistemas de classificação e tesauros, que têm por base a Teoria da Classificação Facetada, a Teoria do Conceito e a Teoria Geral da Terminologia, para a formação de estruturas sistemáticas, pois os conceitos de uma área de conhecimento se encontram relacionados entre si. Esses princípios são constituídos por elementos que estão na base da formação de tal estrutura, que são os conceitos, as relações entre os conceitos e a própria apresentação do sistema de conceitos. (p.167)

O desenvolvimento das classificações facetadas e as pesquisas sobre tesauros trouxeram a convicção de que se deveriam considerar como elementos básicos na construção dos sistemas de classificação não as classes (como subdivisões de um todo), mas os conceitos na sua fecunda capacidade de expressão e de combinação. (p.167)

A Teoria do Conceito [...] é um método para fixação do conteúdo do conceito e para seu posicionamento em um sistema de conceitos. (p.167)

[...] o estabelecimento de uma equivalência entre o termo (o definiendum) e as características necessárias de um referente de um conceito (o definiens), com o propósito de delimitar o uso do termo em um discurso, resulta na definição desse conceito dentro de um sistema. A definição não é mais só um recurso para dirimir dúvidas no uso do termo. A definição possibilita, além da fixação do conceito, seu posicionamento no próprio sistema de conceitos (Dahlberg, 1978). (p.168)

Dahlberg (1978a) utiliza a noção de categoria sob dois aspectos: como um recurso para o entendimento da natureza do conceito e como para a formação de estruturas conceituais. A importância fundamental da categoria na estruturação do conceito e do sistema de conceitos é enfatizada pela mesma autora, quando afirma que se pode ver que as categorias têm uma capacidade de estrutura: não apenas estruturam todos os elementos de conhecimento e unidades de conhecimento; elas fornecem, ao mesmo tempo, por esse meio o esqueleto, os ossos e os tendões para estruturar todo o conhecimento. Com o uso consciencioso, então, o corpo do conhecimento pode se manter unido, pode, se mover, pode se manter flexível e pode crescer organicamente. (p.168)

[...] na terminologia, estudam-se os conceitos enquanto parte de um sistema. Os termos se definem uns em relação aos outros, formando um sistema. (p.168)

Os conceitos se relacionam uns com outros formando um sistema de conceitos terminológico, pois são as representações mentais das relações que ocorrem entre objetos na realidade empírica. Quando tratadas em um nível conceitual, passam a ser consideradas relações lógicas e ontológicas. (p.169)

As relações lógicas resultam da própria compreensão dos conceitos. Chama-se também de relação de semelhança, de similaridade, de abstração ou genérica. As relações ontológicas se dão entre o conceito e a realidade. (p.169)

\subsection{Discussão dos resultados}

$\mathrm{Na}$ análise de citações podemos perceber que existe um conjunto variado de tendências teórico-epistemológicas e teórico-metodológicas sobre o conceito na Organização da informação e do conhecimento nos artigos dos pesquisadores brasileiros. Tais tendências ficaram mais explícitas na análise dos artigos. Desta forma, podemos dizer que:

a) o conceito é abordado majoritariamente para fins operacionais: construção ou análise de instrumentos (classificações, tesauros, ontologias); 
b) a Teoria do Conceito de Dahlberg é presença constante, associada à Teoria Geral da Terminologia e à Teoria da Classificação Facetada de Ranganathan;

c) há abordagens lógicas, voltadas para a organização de sistemas de conceitos;

d) são apresentadas diferenças entre ontologias e tesauros - neste caso, as características e relações ente as unidades constantes de cada um deles;

e) a abordagem lingüística também está presente, via de regra, associada à Teoria Comunicativa da Terminologia e à Socioterminologia;

f) em alguns textos há abordagem filosófica. Neste caso, a preocupação é epistemológica, apresentando visão crítica do sistema conceitual da área da Ciência da informação.

A maior parte dos artigos, como demonstrado, está diretamente relacionada à questões operacionais em torno do conceito. Nesta perspectiva, existe um corpo teóricometodológico constituído por pesquisas já sedimentadas na área de Organização da informação e do conhecimento no Brasil. As principais abordagens destas pesquisas estão pautadas na relação entre a Teoria (analítica) do conceito, a Teoria da classificação facetada, a Teoria geral da terminologia e a ontologia. Dessa forma, autores como Dahlberg, Ranganathan, Wüster e Guarino são presença constante nos artigos analisados. Voltadas para a organização de sistemas de conceitos, as linhas de força teóricas destes artigos estão calcadas, fundamentalmente, na lógica aristotélica, melhor representada pelas categorias, e pelo princípio de fixação da linguagem ou conceitos por meio de juízos e proposições verdadeiras, características básicas da filosofia analítica e do positivismo lógico.

Pode-se afirmar, no entanto, que a discussão crítica da visão aristotélica, da filosofia analítica e do positivismo lógico não é prioridade nas discussões teóricometodológicas. Encontramos explicitamente pontos de abordagem sobre as categorias e lógica aristotélica nas análises sobre teoria do conceito e teoria da classificação, mas não encontramos referências diretas à filosofia analítica e ao positivismo lógico.

O outro conjunto de artigos é de natureza teórico-epistemológica, com foco na discussão conceitual da área da Ciência da informação, mas não especificamente do conceito na Organização da informação. As diferenças deste conjunto de artigos para aqueles já discutidos está na forma e nas teorias que fundamentam a abordagem do conceito. Não há um recurso exclusivo das abordagens à operacionalização de 
conceitos, mas à discussão de algumas teorias freqüentes na área, como é o caso da Teoria comunicativa da terminologia e da Socioterminologia, e outras não tão freqüentes como é caso da semântica do conceito e da história dos conceitos.

Os artigos que abordam a construção conceitual da área de Ciência da Informação fogem ao escopo de nossa tese, pois, relacionam-se à análise de conceitos como os de informação e documento, por exemplo, na constituição científica e epistemológica da área. É importante lembrar que a abordagem efetuada em nossa pesquisa direciona-se apenas ao objeto conceito, naquilo que chamamos ordem dos conceitos na Organização da informação e do conhecimento. Sem a idéia de ordenação de conceitos no sentido estrito, procuramos falar do conceito em relação à filosofia, à ciência, à linguagem, a determinados aspectos de sua formação e na concepção da Organização da informação e do conhecimento. Mas, a manutenção destas abordagens na análise é fundamental, pois, demonstram novas perspectivas de análise de conceitos que não precisam estar, necessariamente, no domínio da Organização da informação e do conhecimento.

Desta maneira, podemos concluir que:

1) A hipótese de que os conceitos não são discutidos nos artigos da área de Organização da informação e do conhecimento no Brasil não foi totalmente comprovada.

2) As principais linhas de força teórico-metodológicas estão centradas em Dahlberg, Ranganathan e Wüster, com forte influência da lógica filosófica, porém, no campo teórico-epistemológico, além da apresentação de novas vertentes na organização de sistemas de conceitos, também são apresentadas abordagens filosóficas, lingüísticas, semânticas, hermenêuticas e epistemológicas, tanto sobre a formação e fronteiras dos conceitos, como sobre a construção de conceitos em campos disciplinares. Neste último caso, não é possível afirmar, além da lingüística, da semântica e da filosofia, quais áreas do conhecimento têm maior influência nas pesquisas sobre o conceito na Organização da informação e do conhecimento no Brasil, pois, algumas pesquisas ainda são recentes.

3) Não foi possível confirmar se as variações nas abordagens sobre o conceito afetam as metodologias de construção de instrumentos de Organização da informação e do conhecimento. De fato, embora existam textos críticos, para a operacionalização de conceitos, são adotados muitos dos procedimentos propostos nos textos criticados. 
4) A ausência de crítica pode promover operacionalização irrefletida. De fato, são poucas as críticas às teorias e metodologias sedimentadas na organização de sistemas de conceitos, cuja base é analítica e lógico-positivista.

5) A ausência de posicionamento crítico pode ser atribuída, por outro lado, a questões de ordem prática. As revistas definem, em geral, um padrão máximo de número de páginas de artigos a serem submetidos para publicação. Esse fator, em muitos casos, leva o autor a sacrificar a apresentação dos aspectos teóricos de um trabalho, para privilegiar os aspectos metodológicos e os dados empíricos de uma pesquisa.

6) É possível dizer que existe uma forte tendência filosófico-pragmática, especialmente no campo da linguagem, sobre as análises teórico-epistemológicas do conceito. Nos artigos que analisam o conceito na perspectiva da Filosofia da linguagem, da Semiótica, da Linguística, da Teoria comunicativa da terminologia e da Socioterminologia, é possível encontrar fundamentação pragmática sobre o uso da linguagem e dos conceitos. Nos artigos de caráter epistemológico e hermenêutico esta fundamentação não é dominante, pois, o foco não está direcionado para o uso de conceitos ou da linguagem, mas para a construção dos conceitos científicos dentro de uma determinada área. 


\section{CONSIDERAÇÕES FINAIS}

A representação por conceitos é matéria secular no plano do conhecimento, como se constatou na presente pesquisa. Na Filosofia diversas tendências tentaram explicar sua origem pelas correntes idealistas, realistas, nominalistas, conceptualistas, empiristas e racionalistas. As teses desenvolvidas por Aristóteles, Kant, Hegel, Descartes, Leibniz, Frege, Wittgenstein, dentre outros, tiveram acolhida no contexto da ciência moderna, no início como doutrinas formalizadoras do discurso lógico-científico e, depois, como depositárias de um intuito desmistificador da linguagem científica universal, determinista e totalitária.

O determinismo conceitual (na filosofia e na ciência) entrou em colapso com a constatação de que a verdade é contextual e não absoluta - resultado da aproximação dos conceitos (expressões de verdade) aos contextos de uso e significado da linguagem. Os significados e usos da linguagem passam a ter centralidade nos princípios antideterministas e paradigmáticos, como os de Bachelard e Kuhn.

Foi possível observar que falar sobre conceitos e linguagem implica identificar e selecionar temas que permitam explorar dois extremos que podem ser chamados fronteiriços/metafóricos e de ordenação.

Se pensarmos na linguagem como acontecimento do conhecimento, seu resultado possível é o conceito. O conceito é produto do acontecimento da linguagem. Uma epistemologia da linguagem tenta explicar os diversos momentos desse acontecimento, ou seja, por quais vias e de que forma é possível se chegar ao conhecimento por conceitos.

Nesse processo, a presença do sujeito epistêmico é fundamental, pois, é ele o responsável pelo acontecimento da linguagem em contextos de uso. Os conceitos tomam formas e entonações nos contextos de uso que nem sempre correspondem aos seus significados pré-fixados e precisão, como vimos com Wittgenstein e González de Gómez.

Não importa se os conceitos são científicos ou não. Em todos os casos, as fronteiras entre campos da experiência são ultrapassadas. Metaforicamente, podemos dizer que suas linhas demarcatórias não são muros intransponíveis, o conhecimento não é construído em redomas de vidro espesso. Pelo contrário, suas linhas são tênues e irregulares, e sua redoma é de uma fina membrana que permite a saída e a entrada de 
conceitos, sem que se rompa.

Os conceitos se organizam e ganham dimensão no "fio" dos enunciados e na maneira como são transcritos e descritos, disse Foucault.

Mas, se aceitamos a posição de Deleuze e Guattari de que apenas a Filosofia cria conceitos, estaríamos negando a condição de formadoras de conceitos à outras disciplinas. Muitos conceitos, inclusive os científicos (átomo, por exemplo), podem ter sua origem no campo filosófico, mas isso não credencia a Filosofia como disciplina única no campo dos conceitos, como foi possível identificar nos textos de natureza epistemológica analisados na presente pesquisa.

Acreditamos, por outro lado, na criação de conceitos em dimensões variadas, na transversalidade do discurso de Foucault, por um sujeito epistêmico dependente de uma comunidade lingüística, em que os conceitos são (re)criados naquilo que chamamos anteriormente de acontecimento do conhecimento pela linguagem. Deleuze e Guattari não negam essas características do conceito, mas situam-nas no campo filosófico.

$\mathrm{Na}$ cognição de Rosch e Vygotsky encontramos formas de abordagem distintas das apresentadas por Foucault, Deleuze e Guattari e Granger. Por outro lado, em todos eles prevalece a noção de que conceitos são compostos por traços, que dependem de relações e que, de alguma forma, dependem da linguagem.

Foi possível observar que todas estas características foram encontradas nas perspectivas adotadas pela Organização da informação e do conhecimento quando o assunto são as teorias e as metodologias sobre o conceito.

Traços, semelhanças e jogos discursivos, fronteiras e domínios científicos, vertentes filosóficas e científicas, os espaços epistêmicos, da cognição e da linguagem, o uso em contextos e a fixação em domínios, as categorias e classificações e os processos sem uma ordenação pré-definida, são alguns dos elementos que ressoaram ao longo desta pesquisa.

Dentro desse contexto, concluímos que há variação de correntes e linhas teóricas e metodológicas sobre o conceito que convivem na área da Organização da informação e do conhecimento. Essas discussões têm abordagem dogmática ou crítica. De todo modo, deve-se insistir sobre a necessidade de aprofundar as pesquisas sobre os fundamentos básicos das teorias e metodologias já sedimentadas no campo para evitar processos de apropriação de conceitos de forma desordenada e irrefletida. A proposta de pesquisar a 
ordem dos conceitos na Organização da informação e do conhecimento visou, essencialmente, comparar, de forma sistemática, os discursos produzidos sobre o conceito e os sistemas de conceitos.

Constatou-se, por outro lado, que o conhecimento produzido sobre o objeto está disperso. Seria de todo interessante que as pesquisas específicas sobre os fundamentos epistemológicos que estão na base das teorias e metodologias sobre o conceito e sua operacionalizadação, sedimentadas na Organização da informação e do conhecimento, sejam sistematizadas e publicadas sob a forma de obras didáticas. Dito de outra forma, seria importante que as propostas de autores clássicos como Ranganathan, Wüster e Dahlberg, sejam disponibilizadas no espaço brasileiro sob a forma de livros. Seria importante, também discutir criticamente essas propostas, confrontando-as com as teorias pragmáticas presentes na Teoria Comunicativa da Terminologia e na Socioterminologia. Da mesma forma, seria fundamental a publicação das contribuições dos autores brasileiros. Também eles já se configuram como clássicos da literatura sobre a Organização da informação e do conhecimento, fato que ficou comprovado na análise de citações.

Uma última questão deve ser colocada. Esta pesquisa é apenas um primeiro passo na discussão sobre as questões epistemológicas, teóricas e metodológicas sobre o conceito no interior das reflexões e operações de organizar informação para circulação e acesso. Desse modo, apenas parte da literatura sobre o tema foi explorada, tendo em vista a pressão do tempo para realizar a pesquisa. Fica como sugestão para estudos futuros a análise de teses, dissertações, trabalhos de eventos e livros, como forma de obter um panorama abrangente sobre o tema. 


\section{BIBLIOGRAFIA}

ABBAGNANO, Nicola. Dicionário de filosofia. 5.ed. São Paulo: Martins Fontes, 2007.

ALMEIDA, Mauricio B.; BAX, Marcello P. Uma visão geral sobre ontologias: pesquisa sobre definições, tipos, aplicações, métodos de avaliação e de construção. Ciência da Informação, v.32, n.3, p.07-20, set./dez. 2003.

ALVARENGA, Lídia. A Teoria do Conceito Revisitada em Conexão com Ontologias e metadados no Contexto das Bibliotecas Tradicionais e Digitais. DataGramaZero Revista de Ciência da Informação, v.2, n.6, Dez. 2001. Acesso em 02/10/2008. Disponível em: http://www.dgz.org.br

ANSI/NISO Z39.19. Guidelines for the construction, format, and management of monolingual controlled vocabularies. Maryland: NISO, 2005.

APEL, Karl-Otto. Transformação da filosofia I: filosofia analítica, semiótica, hermenêutica. 5.ed. São Paulo: Loyola, 2005.

APEL, Karl-Otto. Transformação da filosofia II: o a priori da comunidade de comunicação. São Paulo: Loyola, 2000.

ARAÚJO, Inês Lacerda. Do signo ao discurso: introdução à filosofia da linguagem. São Paulo: Parábola Editorial, 2004.

ARISTÓTELES. Categorias. Tradução, introdução e comentário de Ricardo Santos. Porto, Portugal: Porto Editora, 1995.

BACCEGA, Maria Aparecida. Comunicação e linguagem: discursos e ciência. São Paulo: Moderna, 1998.

BACHELARD, Gaston. A filosofia do não: filosofia do novo espírito científico. Tradução de Joaquim José Moura Ramos. São Paulo: Abril Cultural, 1978. (Os Pensadores).

BACHELARD, Gaston. Ensaio sobre o conhecimento aproximado. Tradução de Estela dos Santos Abreu. Rio de Janeiro: Contraponto, 2004.

BARITÉ, Mario. Diccionario de organización y representación del conocimiento: clasificación, indización, terminologia. Uruguai: s.e., 2000. Acesso em: 25/06/2008. Disponível em: http://www.eubca.edu.uy/diccionario/index.htm.

BARROS, Lidia de Almeida. Curso básico de Terminologia. São Paulo: Edusp, 2004.

BENVENISTE, Émile. Problemas de lingüística geral I. 5.ed. Campinas, SP: Pontes, 2005.

BRAMBILLA, Sônia Domingues Santos; VANZ, Samile Andréa de Souza; STUMPF, Ida Regina C. Mapeamento de um artigo produzido na UFRGS: razões das citações recebidas. Encontros Bibli: revista eletrônica de Biblioteconomia e Ciência da Informação, Florianópolis, n. ${ }^{0}$ especial, $1^{\circ}$ sem. 2006. Acesso em 04/11/2009. Disponível em: http://www.periodicos.ufsc.br/index.php/eb/article/view/359/423

BRITO, Adriano Naves de. Nomes próprios: semântica e ontologia. Brasília: UnB, 2003.

CABRÉ, M. Teresa. La terminología: representación y comunicación. Barcelona: Universitat Pompeu Fabra, 2000. 
CAMPOS, Jorge. Os enigmas do nome: na interface lógica/semântica/pragmática. Porto Alegre: AGE/EDIPUCRS, 2004.

CAMPOS, Maria Luiza de Almeida. Linguagem Documentária: teorias que fundamentam sua elaboração. Niterói: EdUFF, 2001.

CAPURRO, Rafael; HJORLAND, Birger. O conceito de informação. Perspectivas em Ciência da Informação, Belo Horizonte, v.12, n.1, p.148-207, jan./abr. 2007.

CASSIRER, Ernst. Linguagem e mito. 4.ed. São Paulo: Perspectiva, 2003.

CHÂTELET, François. G. W. F. Hegel. In: (Dir.). História da filosofia: de Kant a Husserl. Lisboa: Dom Quixote, 1995. (vol. 3).

CHAUMIER, Jacques. As técnicas documentais. Lisboa: Europa-América, 1973. (Coleção Saber, n.72).

CINTRA, Anna Maria Marques et al. Para entender as linguagens documentárias. 2.ed. São Paulo: Polis, 2002.

CONDÉ, Mauro Lúcio Leitão. Wittgenstein e a gramática da ciência. Unimontes científica, Montes Claros, v.6, n.1, jan./jun. 2004.

COSTA, Cláudio. Uma introdução contemporânea à filosofia. São Paulo: Martins Fontes, 2002.

COSTA, Newton Carneiro Afonso da. Ensaio sobre os fundamentos da lógica. 3.ed. São Paulo: HUCITEC, 2008.

DAHLBERG, Ingetraut. Environment-related conceptual systematization. Knowledge Organization in Subject Areas, Indeks, Verlag, v.1, p.84-94, 1994.

DAHLBERG, Ingetraut. O futuro das linguagens de indexação. Tradução Henry B. Cox. In: CONFERÊNCIA BRASILEIRA DE CLASSIFICAÇÃO BIBLIOGRÁFICA, 1972, Rio de Janeiro. Anais... Brasília: IBICT/ABDF, 1979a. v.1. p.323-334. Acesso em: 02/10/2005. Disponível em: http://www.conexaorio.com/biti/dahlbergteoria/index_teoria.htm

DAHLBERG, Ingetraut. Philosophical foundations of conceptual ordering systems. Advances in Knowledge Organization, n.3, p.102-119, 1991.

DAHLBERG, Ingetraut. Teoria da Classificação, ontem e hoje. Tradução Henry B. Cox. In: CONFERÊNCIA BRASILEIRA DE CLASSIFICAÇÃO BIBLIOGRÁFICA, 1972, Rio de Janeiro. Anais... Brasília: IBICT/ABDF, 1979b. v.1. p.352-370. Acesso em: 02/10/2005. Disponível

em: http://www.conexaorio.com/biti/dahlbergteoria/index teoria.htm

DAHLBERG, Ingetraut. Teoria do conceito. Tradução Astério Tavares Campos. Ciência da Informação, Rio de Janeiro, v.7, n.2, p.101-107, 1978a.

DAHLBERG, Ingetraut. Uma teoria para o interconcept: teoria analítica do conceito voltada para o referente. 1978b. Tradução Vânia Teixeira Gonçalves. Acesso em: 06/03/2008. Disponível em: http://dataware.nce.ufrj.br:8080/dataware/seminarios/2002 /fisico/seminariosInternos/2002/Teoria\%20do\%20Conceito.doc

DELEUZE, Gilles. Lógica do sentido. Tradução de Luiz Roberto Salinas Fortes. 4.ed. São Paulo: Perspectivas, 2007.

DELEUZE, Gilles; GUATTARI, Félix. O que é a filosofia? 2.ed. Rio de Janeiro: Editora 34, 2004. 
DIAS, Maria Clara. Kant e Wittgenstein: os limites da linguagem. Rio de Janeiro: Relume Dumará, 2000.

DODEBEI, Vera Lúcia Doyle. Tesauro: linguagem de representação da memória documentária. Rio de Janeiro: Interciência, 2002.

DREYFUS, Hubert L.; RABINOW, Paul. Michel Foucault, uma trajetória filosófica: para além do estruturalismo e da hermenêutica. Tradução de Vera Porto Carrero. Rio de Janeiro: Forense Universitária, 1995.

DUNNELL, Robert C. Classificação em Arqueologia. Tradução de Astolfo G. M. Araujo. São Paulo: EdUSP, 2007.

DURANT, Will. A história da filosofia. Tradução de Luiz Carlos do Nascimento Silva. São Paulo: Nova Cultural, 1996.

ECO, Umberto. Conceito de texto. São Paulo: TAQ, USP, 1984.

FARIA, Maria Isabel; PERICÃO, Maria da Graça. Dicionário do livro: da escrita ao livro eletrônico. São Paulo: EdUSP, 2008.

FAUSTINO, Silvia. A experiência indizível: uma introdução ao Tratactus de Wittgenstein. São Paulo: Unesp, 2006.

FERRATER MORA, José. Dicionario de filosofia. 2.ed. São Paulo: Loyola, 2004. (Tomo I).

FOUCAULT, Michel. A formação dos conceitos. In: A arqueologia do saber. 7.ed. Rio de Janeiro: Forense Universitária, 2007a.

FOUCAULT, Michel. As palavras e as coisas: uma arqueologia das ciências humanas. 9.ed. São Paulo: Martins Fontes, 2007b.

FOUCAULT, Michel. O sujeito e o poder. In: DREYFUS, Hubert L.; RABINOW, Paul. Michel Foucault, uma trajetória filosófica: para além do estruturalismo e da hermenêutica. Tradução de Vera Porto Carrero. Rio de Janeiro: Forense Universitária, 1995.

FOUREZ, Gérard. A construção das ciências: introdução à filosofia e à ética das ciências. Tradução de Luiz Paulo Rouanet. São Paulo: Unesp, 1995.

FUJITA, Mariângela Spotti Lopes. Organização e representação do conhecimento no Brasil: análise de aspectos conceituais e da produção científica do enancib no período de 2005 a 2007. Tendências da Pesquisa Brasileira em Ciência da Informação, v.1, n.1, 2008. Acesso em: 14/01/2009. Disponível em: http://inseer.ibict.br/ancib/index.php/tpbci/article/view/4/13

FURLANETTO, Maria Marta. Sujeito epistêmico e materialidade do discurso: o efeito de singularidade. Linguagem em (Dis)curso, v.3, número especial, p.91-119, 2003. Acesso em: 26/10/2008. Disponível em: http://www.unisul.br/site/linguagem/0303/8\%20art\%206\%20P.pdf

GALINSKI, Christian; BUDIN, Gerhard. Introducción. In: WÜSTER, Eugen. Introducción a la teoría general de la terminología y a la lexicografía terminológica. Barcelona: Universitat Pompeu Fabra, 1998.

GALVÃO, Maria Cristiane Barbosa. Construção de conceitos no campo da ciência da informação. Ciência da Informação, Brasília, v.27, n.1, p.46-52, jan./abr. 1998. Acesso em 02/10/2008. Disponível em: http://revista.ibict.br 
GARDNER, Howard. A nova ciência da mente. 3.ed. São Paulo: EDUSP, 2003. (Ponta. 9).

GEERTZ, Clifford. O saber local: novos ensaios sobre antropologia interpretativa. 8.ed. Petrópolis, 2006.

GIL, Fernando. O plano da ciência. In: DEUS, Jorge Dias de. (Org.). A crítica da ciência: sociologia e ideologia da ciência. 2.ed. Rio de Janeiro: Zahar Editores, 1979.

GONZÁLEZ DE GÓMEZ, Maria Nélida. A configuração temática da Ciência da Informação no currículo dos cursos do IBICT: estudo de caso. Rio de Janeiro: IBICT, 1982. (Dissertação de Mestrado).

GONZÁLEZ DE GÓMEZ, Maria Nélida. A representação do conhecimento e o conhecimento da representação: algumas questões epistemológicas. Ciência da Informação, v.22, n.3, p.217-222, set./dez. 1993.

GONZÁLEZ DE GÓMEZ, Maria Nélida. A vinculação dos conhecimentos: entre a razão mediada e a razão leve. Liinc em Revista, v.1, n.1, p.16-37, mar. 2005. Acesso em 21/05/2006. Disponível em: http://www.ibict.br/liinc

GONZÁLEZ DE GÓMEZ, Maria Nélida. Caráter seletivo das ações de informação. Informare, v.5, n.2, p.7-31, 1999. Acesso em: 04/02/2007. Disponível em: http://biblioteca.ibict.br/phl8/anexos/nelidacarater.pdf

GONZÁLEZ DE GÓMEZ, Maria Nélida. Comentários ao artigo "Hacia un nuevo paradigma en Bibliotecología". Transinformação, v.8, n.3, p.44-56, set./dez. 1996.

GONZÁLEZ DE GÓMEZ, Maria Nélida. Metodologia de pesquisa no campo da Ciência da Informação. Datagramazero, v.1, n.6, dez. 2000. Acesso em: 12/05/2004. Disponível em: http://www.dgz.org.br

GONZÁLEZ DE GÓMEZ, Maria Nélida. Novas fronteiras tecnológicas das ações de informação: questões e abordagens. Ciência da Informação, Brasília, v.33, n.1, p.5567, jan./abr. 2004.

GONZÁLEZ DE GÓMEZ, Maria Nélida. O contrato social da pesquisa: em busca de uma nova equação entre autonomia epistêmica e autonomia política. Datagramazero, v.4, n.1, fev. 2007. Acesso em: 03/02/2008. Disponível em: http://www.dgz.org.br/fev03/Art_02.htm

GONZÁLEZ DE GÓMEZ, Maria Nélida. O objeto de estudo da Ciência da Informação: paradoxos e desafios. Ciência da Informação, Brasília, v.19, n.2, p.117-122, jul./dez. 1990.

GRANGER, Gilles Gaston. A ciência e as ciências. São Paulo: Unesp, 1994.

GRANGER, Gilles-Gaston. Por um conhecimento filosófico. Campinas: Papirus, 1989.

GUIMARÃES, Eduardo. Semântica do acontecimento: um estudo enunciativo da designação. Campinas: Pontes, 2002.

HAYASHI, Maria Cristina Piumbato Innocentini; HAYASHI, Carlos Roberto Massao; LIMA, Maycke Young de. Análise de redes de co-autoria na produção científica em educação especial. Liinc em Revista, Rio Janeiro, v.4, n.1, p.84-103, mar. 2008. Acesso em: 03/11/2009. Disponível em: http://www.ibict.br/liinc

HEGENBERG, Leônidas. Definições: termos teóricos e significados. São Paulo: 
Cultrix, 1974.

HENRY, Paulo. A ferramenta imperfeita: língua, sujeito e discurso. Campinas: Unicamp, 1992.

HJELMSLEV, Louis. Prolegômenos a uma teoria da linguagem. 2.ed. São Paulo: Perspectiva, 2006.

HJORLAND, Birger. Concept in Knowledge Organization. In: Lifeboat for

Knowledge Organization. 2008. Acesso em: 16/08/2008. Disponível em: http://www.db.dk/bh/lifeboat_ko/CONCEPTS/concept_in_knowledge_organizatio.htm

HOUAISS, Antônio; VILLAR, Mauro de Salles. Grande dicionário Houaiss da língua portuguesa. Rio de Janeiro: Objetiva, 2008.

INGWERSEN, Peter. Information retrieval interaction. London: Taylor Graham, 2002. Acesso em: 15/08/2002. Disponível em: www.db.dk/pi/iri

ISO 1087-1. Terminology work - vocabulary - Part 1: Theory and application. Switzerland: ISO, 2000.

ISO 704. Terminology work - principles and methods. Switzerland: ISO, 2000.

IYER, Hemalata. Classificatory Structures: concepts, relations and representation. Frankfurt/Main: Indeks Verlag, 1995.

KANT, Immanuel. Crítica da razão pura. Tradução de Valerio Rohden e Udo Baldur Moosburger. 3.ed. São Paulo: Nova Cultura, 1987. (Os Pensadores. v.1)

KOBASHI, Nair Yumiko; SMIT, Johanna W; TÁLAMO, Maria de Fátima Gonçalves Moreira. A função da terminologia na construção do objeto da Ciência da Informação. DataGramaZero - Revista de Ciência da Informação, v.2, n.2, Abr. 2001. Acesso em 02/10/2008. Disponível em: http://www.dgz.org.br

KÖCHE, José Carlos. Fundamentos de metodologia científica: teoria da ciência e iniciação à pesquisa. 20.ed. Petrópolis: Vozes, 2002.

KOSELLECK, Reinhart. Futuro passado: contribuição à semântica dos tempos históricos. Rio de Janeiro: Contraponto, 2006.

KOSELLECK, Reinhart. Uma história dos conceitos: problemas teóricos e práticos. Estudos Históricos, Rio de Janeiro, v.5, n.10, p.134-146, 1992. Acesso em: 05/03/2008. Disponível em: www.cpdoc.fgv.br/revista/arq/101.htm

KOYRÉ, Alexandre. Estudos de história do pensamento científico. 2.ed. Rio de Janeiro: Forense Universitária, 1991.

KRIEGER, Maria da Graça; FINATTO, Maria José Bocorny. Introdução à terminologia: teoria e prática. São Paulo: Contexto, 2004.

KRISTEVA, Julia. História da linguagem. Lisboa: Edições 70, 1999.

KUHN, Thomas S. A estrutura das revoluções científicas. 6.ed. São Paulo: Perspectiva, 2001.

KUHN, Thomas S. O caminho desde A estrutura: ensaios filosóficos, 1970-1993, com uma entrevista autobiográfica. São Paulo: Unesp, 2006.

LANCASTER, F. W. Indexação e resumos: teoria e prática. 2.ed. Brasília: Briquet de Lemos, 2004.

LANGRIDGE. Derek. Classificação: abordagem para estudantes de biblioteconomia. 
Tradução de Rosali P. Fernandes. Rio de Janeiro: Interciência, 2006.

LARA, Marilda Lopes Ginez de. Representação e linguagens documentárias: bases teórico-metodológicas. São Paulo: USP, 1999. (Tese de Doutorado).

LE COADIC, Yves-François. A Ciência da Informação. Tradução de Maria Yêda F. S. De Figueiras Gomes. 2.ed. Brasília: Briquet de Lemos, 2004.

LIMA-MARQUES, Mamede. Ontologias: da filosofia à representação do conhecimento. Brasília: Thesaurus, 2006.

LORENZANO, César. Wittgenstein y los paradigmas de Kuhn. Episteme, Porto Alegre, n.11, p.57-67, jul./dez. 2000.

LYONS, John. Introdução à linguística teórica. São Paulo: Editora Nacional, Editora da Universidade de São Paulo, 1979.

MARCONDES, Danilo. Iniciação à história da filosofia: dos pré-socráticos a Wittgenstein. 6.ed. Rio de Janeiro: Jorge Zahar, 2001.

MASTERMAN, Margaret. A natureza do paradigma. In: LAKATOS, Imre; MUSGRAVE, Alan. (Orgs.). A crítica e o desenvolvimento do conhecimento. São Paulo: Cultrix /Universidade de São Paulo, 1979.

MORENO, Arley Ramos. Introdução a uma pragmática filosófica: de uma concepção de filosofia como atividade terapêutica a uma filosofia da linguagem. Campinas, SP: Editora da Unicamp, 2005.

MORIN, Edgar. Introdução ao pensamento complexo. Porto Alegre: Sulina, 2005.

NEISSER, Ulric. (Ed.). Concepts and conceptual development: ecological and intellectual factors in categorization. Cambridge; New York: Cambridge University Press, 1987.

NIETZSCHE, Friedrich. Sobre verdade e mentira no sentido extra-moral. Tradução e notas de Rubens Rodrigues Torres Filho. 4.ed. São Paulo: Nova Cultural, 1987. (Os Pensadores).

NORONHA, Daisy Pires. Análise das citações das dissertações de mestrado e teses de doutorado em saúde pública (1990-1994): estudo exploratório. Ciência da Informação, Brasília, v.27, n.1, p.66-75, jan./abr. 1998. Acesso em: 03/11/2009. Disponível em: http://revista.ibict.br/index.php/ciinf/article/view/353/314

NOVELLINO, Maria Salet Ferreira. A linguagem como meio de representação ou de comunicação da informação. Perspectivas em Ciência da Informação, Belo Horizonte, v.3, n.2, p.137-146, jul./dez.1998.

OLIVEIRA E SILVA, Antonio Braz de; MATHEUS, Renato Fabiano; PARREIRAS, Fernando Silva; PARREIRAS, Tatiane A. Silva. Estudo da rede de co-autoria e da interdisciplinaridade na produção científica com base nos métodos de análise de redes sociais: avaliação do caso do programa de pós-graduação em Ciência da Informação PPGCI / UFMG. Encontros Bibli: revista eletrônica de Biblioteconomia e Ciência da Informação, Florianópolis, n. ${ }^{\circ}$ especial, $1^{\circ}$ sem. 2006. Acesso em 04/11/2009. Disponível em: http://www.periodicos.ufsc.br/index.php/eb

OLIVEIRA, Bernardo Jefferson de; CONDÉ, Mauro Lúcio Leitão. Thomas Kuhn e a historiografia da ciência. Ensaio - Pesquisa em educação em ciências, v.94, n.2, dez. 2002 . 
OLIVEIRA, Manfredo Araújo de. Ética e racionalidade moderna. 2.ed. São Paulo: Loyola, 1993.

OLIVEIRA, Marcos Barbosa de. Da ciência cognitiva à dialética. São Paulo: Discurso Editorial, 1999. (Coleção Filosofia da Ciência e Epistemologia).

OLIVEIRA, Marcos Barbosa de; OLIVEIRA, Marta Kohl de. Investigações cognitivas: conceitos, linguagem e cultura. Porto Alegre: Artes Médicas, 1999.

OLIVEIRA, Marta Kohl de. Vygotsky e o processo de formação de conceitos. In: LA TAILLE, Iyes de; OLIVEIRA, Marta Kohl de; DANTAS, Heloysa. Piaget, Vygotsky, Wallon: teorias psicogenéticas em discussão. São Paulo: Summus, 1992.

PAIVA, Rita de Cássia Souza. Gaston Bachelard: a imaginação na ciência, na poética e na sociologia. São Paulo: Annablume; Fapesp, 2005.

PEIRCE, Charles Sanders. A ética da terminologia. 4.ed. São Paulo: Abril Cultura, 1989. (Os Pensadores).

PIEDADE, Maria Antonieta Requião. Introdução à teoria da classificação. 2.ed. Rio de Janeiro: Interciência, 1983.

PINKER, Steven. Do que é feito o pensamento: a língua como janela para a natureza humana. São Paulo: Companhia das Letras, 2008.

PINKER, Steven. O instinto da linguagem: como a mente cria a linguagem. São Paulo: Martins Fontes, 2004.

PINTO, Paulo Roberto Margutti. A abordagem pragmática do conhecimento. In: VAITSMAN, Jeni; GIRARDI, Sábado. (Orgs.). A ciência e seus impasses: debates e tendências em filosofia, ciências sociais e saúde. Rio de Janeiro: Fiocruz, 1999.

PLATÃO. Crátilo: diálogo sobre a justeza dos nomes. Versão do grego, prefácio e notas: Dias Palmeira. Lisboa: Livraria Sá Costa Editora, 1963.

POMBO, Olga. Da classificação dos seres à classificação dos saberes. Leituras Revista da Biblioteca Nacional de Lisboa, n.2, p.19-33, primavera, 1998.

PORFÍRIO. Isagoge: introdução às Categorias de Aristóteles. Introdução, tradução e comentário de Bento Silva Santos. São Paulo: Attar, 2002.

POZZI, María. ISO 704 e ISO1087-1: dos normas del ISO/TC37 en conflicto. VII Simpósio Riterm, 2000. Anais. Acesso em: 20/09/2008. Disponível em: http://www.riterm.net/actes/7simposio/pozzi.htm

POZZI, María. The concept of "concept" in Terminology: a need for a new approach. México, 1999.

PRIMO, Alex; STUMPF, Ida; CONSONI, Gilberto; SILVEIRA, Stefanie Carlan da. Análise de citações dos trabalhos da Compós 2008. E-compós, Brasília, v.11, n.3, set./dez. 2008. Acesso em: 04/11/2008. Disponível em: http://www.compos.org.br/seer/index.php/e-compos/article/viewFile/328/311

RABELLO, Rodrigo. A face oculta do documento: tradição e inovação no limiar da Ciência da Informação. Marília: Unesp, 2009. (Tese de Doutorado).

RABELLO, Rodrigo. História dos conceitos e Ciência da Informação: apontamentos teórico-metodológicos para uma perspectiva epistemológica. Encontros Bibli: revista eletrônica de Biblioteconomia e Ciência da Informação, Florianópolis, n.26, $2^{\circ}$ sem. 
2008. Acesso em 02/10/2008. Disponível em: http://www.periodicos.ufsc.br/index.php/eb

REALE, Giovanni; ANTISERI, Dario. História da filosofia: do romantismo até nossos dias. 6.ed. São Paulo: Paulus, 2003. (v. III).

RICOEUR, Paul. A metáfora viva. São Paulo: Loyola, 2000.

ROBREDO, Jaime. Da Ciência da Informação revisitada aos sistemas humanos de informação. Brasília: Thesaurus, 2003.

RORTY, Richard. A Filosofia e o espelho da natureza. Tradução de Antônio Trânsito. Rio de Janeiro: Relume Dumará, 1994.

ROVIGHI, Sofia Vanni. História da filosofia contemporânea. Tradução de Ana Pareschi Capovilla. 2.ed. São Paulo: Loyola, 2001.

SANTOS, Boaventura de Sousa. (org). Conhecimento prudente para uma vida decente: 'um discurso sobre as ciências' revisitado. São Paulo: Cortez, 2004.

SANTOS, Boaventura de Sousa. Um discurso sobre as ciências. 3.ed. São Paulo: Cortez, 2005.

SCHÖPKE, Regina. Conceitos e planos de imanência: a criação filosófica. In:_ Por uma filosofia da diferença: Gilles Deleuze, o pensador nômade. Rio de Janeiro: Contraponto, São Paulo: Edusp, 2004.

SHERA, H. Jesse. Padrão, estrutura e conceituação na classificação. Tradução de Hagar Espanha Gomes. 1957. Acesso em: 02/10/2005. Disponível em: http://www.conexaorio.com/biti/shera/index.htm

SILVA, Edson Barbosa da. Semelhanças e possíveis diferenças: paradigmas de Thomas Kuhn e semelhanças de família de Ludwig Wittgenstein. São Paulo: PUC, 1997. (Dissertação de Mestrado).

SILVEIRA, MURILO ARTUR ARAÚJO da; BAZI, Rogério Eduardo Rodrigues. As referências nos estudos de citação: algumas questões para discussão. Datagramazero, v.10, n.4, ago./2009. Acesso em: 04/11/2009. Disponível em: http://www.dgz.org.br/ago09/F_I_art.htm

SMIT, Johanna Wilhelmina; TÁLAMO, Maria de Fátima Gonçalves Moreira; KOBASHI, Nair Yumiko. A determinação do campo científico da Ciência da Informação: uma abordagem terminológica. DataGramaZero - Revista de Ciência da Informação, v.5, n.1, Fev. 2004. Acesso em 02/10/2008. Disponível em: http://www.dgz.org.br

SMITH, Edward E.; MEDIN, Douglas L. Categories and concepts. Cambridge: Harvard University Press, 1981.

SNOW, S. P. As duas culturas e uma segunda leitura. São Paulo: Edusp, 1995.

SOKAL, Alan; BRICMONT, Jean. Imposturas intelectuais: o abuso da ciência pelos filósofos pós-modernos. 2.ed. Rio de Janeiro: Record, 2001.

SOWA, John F. Knowledge representation: logical, philosophical, and computational foundations. Pacific Grove: Brooks/Cole, 2000.

SPINAK, Ernesto. Dicionário enciclopédico de bibliometría, cienciometría e informetría. Caracas, Venezuela: Unesco, 1996. 
TÁLAMO, Maria de Fátima Gonçalves Moreira. A pesquisa: recepção da informação e produção do conhecimento. Datagramazero, v.5, n.2, abr. 2004. Acesso em 11/08/2006. Disponível em: www.dg.org.br/abr04/Art_01.htm

TÁLAMO, Maria de Fátima Gonçalves Moreira. Definição semântica para elaboração de glossários. In: SMIT, Johanna Wilhelmina. (Coord.). Análise documentária: a análise da síntese. Brasília: IBICT, 1987.

VAN DER VEER, René; VALSINER, Jaan. O universo das palavras: a visão de Vygotsky sobre a formação de conceitos. In: Vygotsky: uma síntese. 3.ed. São Paulo: Loyola, 1999.

VICKERY, Brian C. Classificação e indexação nas ciências. Tradução de Maria Cristina Girão Pirolla. Rio de Janeiro: BNG/Brasilart, 1980. (Coleção Biblioteconomia, Documentação, Ciência da Informação).

VIULLEMIN, Jules. Conceito. In: ENCICLOPÉDIA EINAUDI. Conceito Filosofia/Filosofias. Portugal: Imprensa Nacional - Casa da Moeda, 1997.

VYGOTSKY, Lev. Pensamento e linguagem. 3.ed. São Paulo: Martins Fontes, 1991.

WEEDWOOD, Barbara. História concisa da Linguiística. 4.ed. São Paulo: Parábola Editorial, 2005. (Na ponta da língua, 3).

WILDEN, Anthony. Informação. In: ENCICLOPÉDIA EINAUDI. Comunicação Cognição. Portugal: Imprensa Nacional - Casa da Moeda, 2000.

WILSON, John. Pensar com conceitos. 2.ed. São Paulo: Martins Fontes, 2005. (Coleção Ferramentas).

WITTGENSTEIN, Ludwig. Investigações filosóficas. 3.ed. Petrópolis: Vozes, 2005.

WITTGENSTEIN, Ludwig. Tratactus logico-philosophicus. 3.ed. São Paulo: Edusp, 2001.

WOLFF, Francis. Dizer o mundo. São Paulo: Discurso Editorial, 1999.

WÜSTER, Eugen. Introducción a la teoría general de la terminología y a la lexicografía terminológica. Barcelona: Universitat Pompeu Fabra, 1998. 


\section{APÊNDICE A \\ LEVANTAMENTO E SELEÇÃO DOS ARTIGOS DO CORPUS DE ANÁLISE}


Tabela 1. Artigos relacionados para análise - Primeira seleção.

1. ALMEIDA, Maurício Barcellos; MOURA, Maria Aparecida; CARDOSO, Ana Maria Pereira; CENDÓN, Beatriz Valadares. Uma iniciativa interinstitucional para a construção de ontologia sobre ciência da informação: visão geral do projeto P.O.I.S. Encontros Bibli: revista eletrônica de Biblioteconomia e Ciência da Informação, Florianópolis, v.10, n.19, $1^{\circ}$ sem. 2007. Acesso em 02/10/2008. Disponível em: http://www.periodicos.ufsc.br/index.php/eb

2. ALVARENGA, Lídia. A Teoria do Conceito Revisitada em Conexão com Ontologias e Metadados no Contexto das Bibliotecas Tradicionais e Digitais. DataGramaZero - Revista de Ciência da Informação, v.2, n.6, Dez. 2001. Acesso em 02/10/2008. Disponível em: http://www.dgz.org.br

3. ALVARENGA, Lídia. Representação do conhecimento na perspectiva da ciência da informação em tempo e espaço digitais. Encontros Bibli: revista eletrônica de Biblioteconomia e Ciência da Informação, Florianópolis, v.8, n.15, $1^{\circ} \mathrm{sem}$. 2003. Acesso em 02/10/2008. Disponível em: http://www.periodicos.ufsc.br/index.php/eb

4. ARAÚJO, Carlos Alberto Ávila. Fundamentos teóricos da classificação. Encontros Bibli: revista eletrônica de Biblioteconomia e Ciência da Informação, Florianópolis, v.11, n.22, $2^{\circ}$ sem. 2006. Acesso em 02/10/2008. Disponível em: http://www.periodicos.ufsc.br/index.php/eb

5. AZEVEDO NETTO, Carlos Xavier de. A abordagem do conceito como uma estrutura semiótica. Transinformação, Campinas, v.20, n.1, p.47-58, jan./abr. 2008. Acesso em 02/10/2008. Disponível em: http://revistas.puc-campinas.edu.br/transinfo/index.php

6. AZEVEDO NETTO, Carlos Xavier de. Signo, sinal, informação: as relações de construção e transferência de significados. Informação \& Sociedade: Estudos, João Pessoa, v.12, n.2. 2002. Acesso em 02/10/2008. Disponível em: http://www.ies.ufpb.br/ojs2/index.php/ies

7. BARBALHO, Célia Regina Simonetti. Fazer semiótico: subsídios para exame do espaço concreto. Encontros Bibli: revista eletrônica de Biblioteconomia e Ciência da Informação, Florianópolis, $2^{\circ}$ n. especial, $2^{\circ}$ sem. 2006. Acesso em 02/10/2008. Disponível em: http://www.periodicos.ufsc.br/index.php/eb

8. BARBOSA, Maria Aparecida. Contribuição ao estudo de aspectos da tipologia de obras lexicográficas. Ciência da Informação, Brasília, v.24, n.3. 1995. Acesso em 02/10/2008. Disponível em: http://revista.ibict.br

9. BARITÉ, Mario. Los procesos de normalizacion, armonizacion y compatibilizacion en el Mercosur: impactos en el sector información. Informação \& Informação, Londrina, v.5, n.1, p.42-60, jan./jun. 2000. Acesso em 02/10/2008. Disponível em: http://www2.uel.br/revistas/informacao

10. BARRETO, Aldo de Albuquerque. A estrutura do texto e a transferência da informação. DataGramaZero - Revista de Ciência da Informação, v.6, n.3, Jun. 2005. Acesso em 02/10/2008. Disponível em: http://www.dgz.org.br

11. BATISTA, Gilda Helena Rocha. Redes de conceitos. Perspectivas em Ciência da Informação, Belo Horizonte, v.9, n.1, p.6-17, jan./jun. 2004. Acesso em 02/10/2008. Disponível em: www.eci.ufmg.br/pcionline

12. BIOLCHINI, Jorge Calmon de Almeida. Semântica e Cognição em Bases de Conhecimento: do vocabulário controlado à ontologia. DataGramaZero - Revista de Ciência da Informação, v.2, n.5, Out. 2001. Acesso em 02/10/2008. Disponível em: 


\begin{tabular}{|c|}
\hline http://www.dgz.org.br \\
\hline $\begin{array}{l}\text { 13. BOULANGER, Jean-Claude. Alguns componentes lingüísticos no ensino da terminologia. } \\
\text { Ciência da Informação, Brasília, v.24, n.3. 1995. Acesso em 02/10/2008. Disponível em: } \\
\text { http://revista.ibict.br }\end{array}$ \\
\hline $\begin{array}{l}\text { 14. BRÄSCHER, Marisa. A Ambigüidade na Recuperação da Informação. DataGramaZero - } \\
\text { Revista de Ciência da Informação, v.3, n.1, Fev. 2002. Acesso em 02/10/2008. Disponível } \\
\text { em: } \underline{\text { http://www.dgz.org.br }}\end{array}$ \\
\hline $\begin{array}{l}\text { 15. BUFREM, Leilah Santiago. Levantando significações para significantes: da gestão do } \\
\text { conhecimento a organização do saber. Encontros Bibli: revista eletrônica de } \\
\text { Biblioteconomia e Ciência da Informação, Florianópolis, n. especial, } 1^{\circ} \text { sem. 2004. Acesso } \\
\text { em 02/10/2008. Disponível em: http://www.periodicos.ufsc.br/index.php/eb }\end{array}$ \\
\hline $\begin{array}{l}\text { 16. CABRÉ, Maria Teresa. La terminología hoy: concepciones, tendencias y aplicaciones. Ciência } \\
\text { da Informação, Brasília, v.24, n.3. 1995. Acesso em 02/10/2008. Disponível em: } \\
\text { http://revista.ibict.br }\end{array}$ \\
\hline $\begin{array}{l}\text { 17. CAFÉ, Ligia Maria Arruda; BRATFISCH, Alline. Classificação analítico-sintética: reflexões } \\
\text { teóricas e aplicações. Transinformação, Campinas, v.19, n.3, p.237-250, set./dez. } 2007 . \\
\text { Acesso em 02/10/2008. Disponível em: } \underline{\text { http://revistas.puc-campinas.edu.br/transinfo/index.php }}\end{array}$ \\
\hline $\begin{array}{l}\text { 18. CAFÉ, Ligia; BRÄSCHER, Marisa. Organização da informação e bibliometria. Encontros } \\
\text { Bibli: revista eletrônica de Biblioteconomia e Ciência da Informação, Florianópolis, n. } \\
\text { especial, } 1^{\text {o }} \text { sem. } 2008 \text {. Acesso em } 02 / 10 / 2008 . \\
\text { http://www.periodicos.ufsc.br/index.php/eb }\end{array}$ \\
\hline $\begin{array}{l}\text { 19. CAMPOS, Maria Luiza de Almeida. Modelização de domínios de conhecimento: uma } \\
\text { investigação de princípios fundamentais. Ciência da Informação, Brasília, v.33, n.1, p.22-32, } \\
\text { jan./abr. 2004. Acesso em 02/10/2008. Disponível em: } \underline{\text { http://revista.ibict.br }}\end{array}$ \\
\hline $\begin{array}{l}\text { 20. CAMPOS, Maria Luiza de Almeida. Perspectivas para o estudo da área de representação da } \\
\text { informação. Ciência da Informação, Brasília, v.25, n.2. 1995. Acesso em 02/10/2008. } \\
\text { Disponível em: } \underline{\text { http://revista.ibict.br }}\end{array}$ \\
\hline $\begin{array}{l}\text { 21. CAMPOS, Maria Luiza de Almeida; GOMES, Hagar Espanha. Metodologia de elaboração de } \\
\text { tesauro conceitual: a categorização como princípio norteador. Perspectivas em Ciência da } \\
\text { Informação, Belo Horizonte, v.11, n.3, p.348-359, set./dez. 2006. Acesso em 02/10/2008. } \\
\text { Disponível em: www.eci.ufmg.br/pcionline }\end{array}$ \\
\hline $\begin{array}{l}\text { 22. CAMPOS, Maria Luiza de Almeida; GOMES, Hagar Espanha. Organização de domínios de } \\
\text { conhecimento e os princípios ranganathianos. Perspectivas em Ciência da Informação, Belo } \\
\text { Horizonte, v.8, n.2, p.150-163, jul./dez. 2003. Acesso em 02/10/2008. Disponível em: } \\
\text { www.eci.ufmg.br/pcionline }\end{array}$ \\
\hline $\begin{array}{l}\text { 23. CAMPOS, Maria Luiza de Almeida; GOMES, Hagar Espanha. Princípios de Organização e } \\
\text { Representação do Conhecimento na Construção de Hiperdocumentos. DataGramaZero - } \\
\text { Revista de Ciência da Informação, v.6, n.6, Dez. 2005. Acesso em 02/10/2008. Disponível } \\
\text { em: http://www.dgz.org.br }\end{array}$ \\
\hline $\begin{array}{l}\text { 24. CAMPOS, Maria Luiza de Almeida; GOMES, Hagar Espanha. Taxonomia e Classificação: o } \\
\text { princípio de categorização. DataGramaZero - Revista de Ciência da Informação, v.9, n.4, } \\
\text { Ago. 2008. Acesso em 02/10/2008. Disponível em: } \underline{\text { http://www.dgz.org.br }}\end{array}$ \\
\hline
\end{tabular}


25. CAMPOS, Maria Luiza de Almeida; SOUZA, Rosali Fernandez de; CAMPOS, Maria Luiza Machado. Organização de unidades de conhecimento em hiperdocumentos: o modelo conceitual como espaço comunicacional para a realização da autoria. Ciência da Informação, Brasília, v.32, n.2, p.07-16, maio/ago. 2003. Acesso em 02/10/2008. Disponível em: http://revista.ibict.br

26. CHALAÇA, Anderson Morais; FREIRE, Isa Maria; MIRANDA, Marcos Luiz Cavalcanti de. O tesouro de conhecimentos de um bairro chamado maré: pessoas como fontes de informação. Encontros Bibli: revista eletrônica de Biblioteconomia e Ciência da Informação, Florianópolis, v.12, n.24, $2^{\mathbf{o}}$ sem. 2007. Acesso em 02/10/2008. Disponível em: http://www.periodicos.ufsc.br/index.php/eb

27. DAhlbERG, Ingetraut. Teoria do conceito. Tradução Astério Tavares Campos. Ciência da Informação, Rio de Janeiro, v.7, n.2, p.101-107, 1978.

28. DATTA, Suman. A organização de conceitos para recuperação da informação. Ciência da Informação, Rio de Janeiro, v.6, n.1, p.17-28. 1977.

29. DIAS, Eduardo Wense. Análise de assunto: percepção do usuário quanto ao conteúdo de documentos. Perspectivas em Ciência da Informação, Belo Horizonte, v.9, n.2, p.146-157, jul./dez. 2004. Acesso em 02/10/2008. Disponível em: www.eci.ufmg.br/pcionline

30. DIAS, Eduardo Wense; NAVES, Madalena Martins Lopes; MOURA, Maria Aparecida. O usuário-pesquisador e a análise de assunto. Perspectivas em Ciência da Informação, Belo Horizonte, v.6, n.2, p.205-221, jul./dez. 2001. Acesso em 02/10/2008. Disponível em: www.eci.ufmg.br/pcionline

31. DODEBEI, Vera; GOUVEIA, Inês. Memória do futuro no ciberespaço : entre lembrar e esquecer. DataGramaZero - Revista de Ciência da Informação, v.9, n.5, Out. 2008. Acesso em 02/10/2008. Disponível em: http://www.dgz.org.br

32. DUARTE, Elizabeth Andrade; CERQUEIRA, Roberto Figueiredo Paletta de. Análise facetada: um olhar face a modelagem conceitual. Revista Digital de Biblioteconomia e Ciência da Informação, Campinas, v.4, n.2, p.39-52, jan./jun. 2007. Acesso em 02/10/2008. Disponível em: http://server01.bc.unicamp.br/seer/ojs/index.php

33. FAULSTICH, Enilde Leite de Jesus. Socioterminologia: mais que um método de pesquisa, uma disciplina. Ciência da Informação, Brasília, v.24, n.3. 1995. Acesso em 02/10/2008. Disponível em: http://revista.ibict.br

34. FREIRE, Isa Maria. Informação; consciência possível; campo. Um exercício com construtos teóricos. Ciência da Informação, Brasília, v.24, n.1. 1995. Acesso em 02/10/2008. Disponível em: $\underline{\text { http://revista.ibict.br }}$

35. FREIRE, Isa Maria; ARAUJO, Vania M. R. Hermes de. Tecendo a rede de Wersig com os indícios de Ginzburg. DataGramaZero - Revista de Ciência da Informação, v.2, n.4, Ago. 2001. Acesso em 02/10/2008. Disponível em: http://www.dgz.org.br

36. FUJITA, Mariângela Spotti Lopes. A identificação de conceitos no processo de análise de assunto para indexação. Revista Digital de Biblioteconomia e Ciência da Informação, Campinas, v.1, n.1, p.60-90, jul./dez. 2003. Acesso em 02/10/2008. Disponível em: http://server01.bc.unicamp.br/seer/ojs/index.php

37. FUJITA, Mariângela Spotti Lopes. A Leitura Documentária na perspectiva de suas variáveis: leitor-texto-contexto. DataGramaZero - Revista de Ciência da Informação, v.5, n.4, Ago. 
2004. Acesso em 02/10/2008. Disponível em: http://www.dgz.org.br

38. FUJITA, Mariângela Spotti Lopes; RUBI, Milena Polsinelli. Um modelo de leitura documentária para a indexação de artigos científicos: princípios de elaboração e uso para a formação de indexadores. DataGramaZero - Revista de Ciência da Informação, v.7, n.3, Jun. 2006. Acesso em 02/10/2008. Disponível em: http://www.dgz.org.br

39. GALVÃO, Maria Cristiane Barbosa. A linguagem de especialidade e o texto técnico-científico: notas conceituais. Transinformação, Campinas, v.16, n.3, p.241-251, set./dez. 2004. Acesso em 02/10/2008. Disponível em: http://revistas.puc-campinas.edu.br/transinfo/index.php

40. GALVÃO, Maria Cristiane Barbosa. Construção de conceitos no campo da ciência da informação. Ciência da Informação, Brasília, v.27, n.1, p.46-52, jan./abr. 1998. Acesso em 02/10/2008. Disponível em: http://revista.ibict.br

41. GÁLVEZ, Carmen. Identificación de nombres personales por medio de sistemas de codificación fonética. Encontros Bibli: revista eletrônica de Biblioteconomia e Ciência da Informação, Florianópolis, v.11, n.22, $2^{\circ}$ sem. 2006. Acesso em 02/10/2008. Disponível em: http://www.periodicos.ufsc.br/index.php/eb

42. GARCÍA GUTIÉRREZ, Antonio. Cientificamente favelados: uma visão crítica do conhecimento a partir da epistemografia. Transinformação, Campinas, v.18, n.2, p.103-112, maio/ago. 2006. Acesso em 02/10/2008. Disponível em: http://revistas.puccampinas.edu.br/transinfo/index.php

43. GARCÍA GUTIÉRREZ, Antonio. Projectar la memoria: del ordo nacional a la reapropiación crítica. Transinformação, Campinas, v.15, n.1, p.7-30, jan./abr. 2003. Acesso em 02/10/2008. Disponível em: http://revistas.puc-campinas.edu.br/transinfo/index.php

44. GOMES, Hagar Espanha; CAMPOS, Maria Luiza de Almeida. Tesauro e normalização terminológica: o termo como base para intercâmbio de informações. DataGramaZero Revista de Ciência da Informação, v.5, n.6, Dez. 2004. Acesso em 02/10/2008. Disponível em: http://www.dgz.org.br

45. GONZALEZ DE GÓMEZ, Maria Nélida. A vinculação dos conhecimentos: entre a razão mediada e a razão leve. Liinc em revista, v.1, n.1, mar. 2005. Acesso em 02/10/2008. Disponível em: http://www.liinc.ufrj.br/pt/

46. GONZÁLEZ, José Moreiro; MORILLO, Juan Llorens; GARCÍA-QUISMOND, Miguel Ángel Marzal; LARA, Jorge Morato; ORENES, Pilar Beltrán; CUADRADO, Sonia Sánchez. De los tesauros a los topic maps: nuevo estándar para la representación y la organización de la información. Encontros Bibli: revista eletrônica de Biblioteconomia e Ciência da Informação, Florianópolis, v.9, n.18, $2^{\circ}$ sem. 2004. Acesso em 02/10/2008. Disponível em: http://www.periodicos.ufsc.br/index.php/eb

47. GUIMARÃES, José Augusto Chaves. A dimensão teórica do tratamento temático da informação e suas interlocuções com o universo científico da international society for knowledge organization (ISKO). Revista Ibero-americana de Ciência da Informação. v.1, n.1, jan./abr. 2008. Acesso em 02/10/2008. Disponível em: http://164.41.105.3/portalnesp/ojs2.1.1/index.php/rici/issue/view/52

48. GUIMARÃES, José Augusto Chaves; MILANI, Suellen Oliveira; PINHO, Fabio Assis. Aspectos éticos em organização e representação do conhecimento (ORC): uma análise preliminar de valores e problemas a partir da literatura internacional da área. Encontros Bibli: revista eletrônica de Biblioteconomia e Ciência da Informação, Florianópolis, v.13, n.25, $1^{\text {o }}$ 


\begin{tabular}{|c|c|}
\hline & sem. 2008. Acesso em 02/10/2008. Disponível em: http://www.periodicos.ufsc.br/index.php/eb \\
\hline 49. & $\begin{array}{l}\text { GUIMARÃES, José Augusto Chaves; PINHO, Fábio Assis. Desafios da representação do } \\
\text { conhecimento: abordagem ética. Informação \& Informação, Londrina, v.12, n.1, jan./jun. } \\
\text { 2007. Acesso em 02/10/2008. Disponível em: http://www2.uel.br/revistas/informacao }\end{array}$ \\
\hline 50. & $\begin{array}{l}\text { KOBASHI, Nair Yumiko. Fundamentos semânticos e pragmáticos da construção de } \\
\text { instrumentos de representação de informação. DataGramaZero - Revista de Ciência da } \\
\text { Informação, v.8, n.6, Dez. 2007. Acesso em 02/10/2008. Disponível em: } \\
\text { http://www.dgz.org.br }\end{array}$ \\
\hline 51. & $\begin{array}{l}\text { KOBASHI, Nair Yumiko; SMIT, Johanna W; TÁLAMO, Maria de Fátima Gonçalves Moreira. } \\
\text { A função da terminologia na construção do objeto da Ciência da Informação. DataGramaZero } \\
\text { - Revista de Ciência da Informação, v.2, n.2, Abr. 2001. Acesso em 02/10/2008. Disponível } \\
\text { em: http://www.dgz.org.br }\end{array}$ \\
\hline 52. & $\begin{array}{l}\text { KOBASHI, Nair Yumiko; TÁLAMO, Maria de Fátima Gonçalves Moreira. Informação: } \\
\text { fenômeno e objeto de estudo da sociedade contemporânea. Transinformação, Campinas, v.15, } \\
\text { ed. especial, p.7-21, set./dez. 2003. Acesso em 02/10/2008. Disponível em: http://revistas.puc- } \\
\text { campinas.edu.br/transinfo/index.php }\end{array}$ \\
\hline 53. & $\begin{array}{l}\text { LARA, Marilda Lopes Ginez de. Diferenças conceituais sobre termos e definições e } \\
\text { implicações na organização da linguagem documentária. Ciência da Informação, Brasília, } \\
\text { v.33, n.2, p.91-96, maio/ago. 2004. Acesso em 02/10/2008. Disponível em: } \\
\text { http://revista.ibict.br }\end{array}$ \\
\hline 54. & $\begin{array}{l}\text { LARA, Marilda Lopes Ginez de. É possível falar em signo e semiose documentária? } \\
\text { Encontros Bibli: revista eletrônica de Biblioteconomia e Ciência da Informação, } \\
\text { Florianópolis, } 2^{\circ} \text { n. especial, } 2^{\circ} \text { sem. 2006. Acesso em 02/10/2008. Disponível em: } \\
\text { http://www.periodicos.ufsc.br/index.php/eb }\end{array}$ \\
\hline 55. & $\begin{array}{l}\text { LARA, Marilda Lopes Ginez de. Linguagem documentária e terminologia. Transinformação, } \\
\text { Campinas, v.16, n.3, p.231-240, set./dez. 2004. Acesso em 02/10/2008. Disponível em: } \\
\text { http://revistas.puc-campinas.edu.br/transinfo/index.php }\end{array}$ \\
\hline 56. & $\begin{array}{l}\text { LARA, Marilda Lopes Ginez de. Novas relações entre Terminologia e Ciência da Informação } \\
\text { na perspectiva de um conceito contemporâneo da informação. DataGramaZero - Revista de } \\
\text { Ciência da Informação, v.7, n.4, Ago. 2006. Acesso em 02/10/2008. Disponível em: } \\
\text { http://www.dgz.org.br }\end{array}$ \\
\hline 57. & $\begin{array}{l}\text { LARA, Marilda Lopes Ginez de. O processo de construção da informação documentária e o } \\
\text { processo de conhecimento. Perspectivas em Ciência da Informação, Belo Horizonte, v.7, n.2, } \\
\text { p.127-139, jul./dez. 2002. Acesso em 02/10/2008. Disponível em: www.eci.ufmg.br/pcionline }\end{array}$ \\
\hline 58. & $\begin{array}{l}\text { LARA, Marilda Lopes Ginez de. O Unicórnio (o Rinoceronte, o Ornitorrinco ... ), a Análise } \\
\text { Documentária e a Linguagem Documentária. DataGramaZero - Revista de Ciência da } \\
\text { Informação, v.2, n.6, Dez. 2001. Acesso em } 02 / 10 / 2008 \text {. Disponível em: } \\
\text { http://www.dgz.org.br }\end{array}$ \\
\hline 59. & $\begin{array}{l}\text { LARA, Marilda Lopes Ginez de; TÁLAMO, Maria de Fátima Gonçalves Moreira. Uma } \\
\text { experiência na interface Lingüística Documentária e Terminologia. DataGramaZero - Revista } \\
\text { de Ciência da Informação, v.8, n.5, Out. 2007. Acesso em 02/10/2008. Disponível em: } \\
\text { http://www.dgz.org.br }\end{array}$ \\
\hline 60. & LIMA, Gercina Angela Borem de Oliveira. A \\
\hline
\end{tabular}




\begin{tabular}{|c|c|}
\hline & $\begin{array}{l}\text { organização hipertextual de documentos acadêmicos: sua aplicação no protótipo MHTX (mapa } \\
\text { hipertextual). Informação \& Sociedade: Estudos, João Pessoa, v.17, n.1, p.31-41, jan./abr. } \\
\text { 2007. Acesso em 02/10/2008. Disponível em: http://www.ies.ufpb.br/ojs2/index.php/ies }\end{array}$ \\
\hline 61. & $\begin{array}{l}\text { LIMA, Gercina Ângela Borém. Análise facetada na modelagem conceitual de sistemas de } \\
\text { hipertexto: uma revisão de literatura. Perspectivas em Ciência da Informação, Belo } \\
\text { Horizonte, v.7, n.2, p.189-196, jul./dez. 2002. Acesso em 02/10/2008. Disponível em: } \\
\text { www.eci.ufmg.br/pcionline }\end{array}$ \\
\hline 62. & $\begin{array}{l}\text { LIMA, Gercina Ângela Borém. Interfaces entre a ciência da informação e a ciência cognitiva. } \\
\text { Ciência da Informação, Brasília, v.32, n.1, p.77-87, jan./abr. 2003. Acesso em 02/10/2008. } \\
\text { Disponível em: http://revista.ibict.br }\end{array}$ \\
\hline 63. & $\begin{array}{l}\text { LIMA, Gercina Ângela Borém. Mapa conceitual como ferramenta para organização do } \\
\text { conhecimento em sistema de hipertexto e seus aspectos cognitivos. Perspectivas em Ciência } \\
\text { da Informação, Belo Horizonte, v.9, n.2, p.134-145, jul./dez. 2004. Acesso em 02/10/2008. } \\
\text { Disponível em: www.eci.ufmg.br/pcionline }\end{array}$ \\
\hline 64. & $\begin{array}{l}\text { LIMA, Vânia Mara Alves. A informação documentária: codificação e decodificação. } \\
\text { Transinformaçãa, Campinas, v.19, n.2, p.119-127, maio/ago. 2007. Acesso em 02/10/2008. } \\
\text { Disponível em: http://revistas.puc-campinas.edu.br/transinfo/index.php }\end{array}$ \\
\hline 65. & $\begin{array}{l}\text { LOPES, Ilza Leite. Uso das linguagens controlada e natural em bases de dados: revisão da } \\
\text { literatura. Ciência da Informação, Brasília, v.31, n.1, p.41-52, jan./abr. 2002. Acesso em } \\
\text { 02/10/2008. Disponível em: http://revista.ibict.br }\end{array}$ \\
\hline 66. & $\begin{array}{l}\text { MARCONDES, Carlos Henrique; CAMPOS, Maria Luiza de Almeida. Ontologia e web } \\
\text { semântica: o espaço da pesquisa em ciência da informação. Ponto de Acesso, Salvador, v.2, } \\
\text { n.1, p.107-136, jun./jul. 2008. Acesso em } 02 / 10 / 2008 \text {. Disponível em: } \\
\text { http://www.portalseer.ufba.br/index.php/revistaici }\end{array}$ \\
\hline 67. & $\begin{array}{l}\text { MARTELETO, Regina Maria. A "Informação Construída" nos meandros dos conceitos da } \\
\text { Teoria Social de Pierre Bordieu. DataGramaZero - Revista de Ciência da Informação, v.5, } \\
\text { n.5, Out. 2004. Acesso em 02/10/2008. Disponível em: http://www.dgz.org.br }\end{array}$ \\
\hline 68. & $\begin{array}{l}\text { MARTELETO, Regina Maria. Cultura informacional: construindo o objeto informação pelo } \\
\text { emprego dos conceitos de imaginário, instituição e campo social. Ciência da Informação, } \\
\text { Brasília, v.24, n.1. 1995. Acesso em 02/10/2008. Disponível em: http://revista.ibict.br }\end{array}$ \\
\hline 69. & 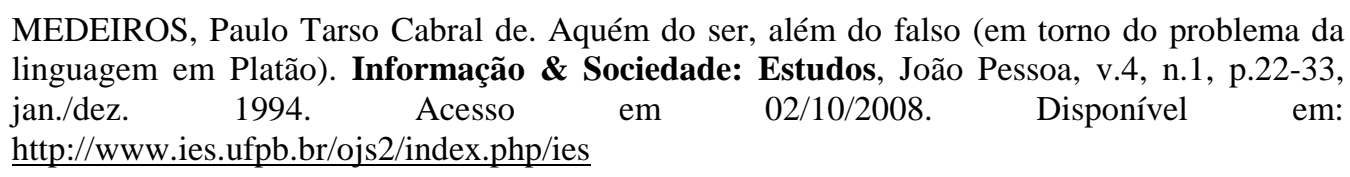 \\
\hline 70. & $\begin{array}{l}\text { MENDONÇA, Ercilia Severina. A lingüística e a ciência da informação: estudos de uma } \\
\text { interseção. Ciência da Informação, Brasília, v.29, n.3, p.50-70, set./dez. 2000. Acesso em } \\
\text { 02/10/2008. Disponível em: http://revista.ibict.br }\end{array}$ \\
\hline 71. & $\begin{array}{l}\text { MONTEIRO, Silvana Drumond. O Ciberespaço: o termo, a definição e o conceito. } \\
\text { DataGramaZero - Revista de Ciência da Informação, v.8, n.3, Jun. 2007. Acesso em } \\
\text { 02/10/2008. Disponível em: http://www.dgz.org.br }\end{array}$ \\
\hline 72. & $\begin{array}{l}\text { MONTEIRO, Silvana Drumond. Semiótica peirciana e a questão da informação e do } \\
\text { conhecimento. Encontros Bibli: revista eletrônica de Biblioteconomia e Ciência da } \\
\text { Informação, Florianópolis, } 2^{\circ} \text { n. especial, } 2^{\circ} \text { sem. } 2006 \text {. Acesso em } 02 / 10 / 2008 \text {. Disponível }\end{array}$ \\
\hline
\end{tabular}




\begin{tabular}{|c|c|}
\hline & em: http://www.periodicos.ufsc.br/index.php/eb \\
\hline 73. & $\begin{array}{l}\text { MORAES, Alice Ferry de; ARCELLO, Etelvina Nunes. O conhecimento e sua representação. } \\
\text { Informação \& Sociedade: Estudos, João Pessoa, v.10, n.2. 2000. Acesso em 02/10/2008. } \\
\text { Disponível em: } \underline{\text { http://www.ies.ufpb.br/ojs2/index.php/ies }}\end{array}$ \\
\hline 74. & $\begin{array}{l}\text { MOREIRA, Alexandra; ALVARENGA, Lídia; OLIVEIRA, Alcione de Paiva. O nível do } \\
\text { conhecimento e os instrumentos de representação: tesauros e ontologias. DataGramaZero - } \\
\text { Revista de Ciência da Informação, v.5, n.6, Dez. 2004. Acesso em 02/10/2008. Disponível } \\
\text { em: http://www.dgz.org.br }\end{array}$ \\
\hline 75. & $\begin{array}{l}\text { MOREIRA, Alexandra; OLIVEIRA, Alcione de Paiva. Contribuição da terminologia na } \\
\text { modelagem de sistemas computacionais. DataGramaZero - Revista de Ciência da } \\
\text { Informação, v.6, n.5, Out. 2005. Acesso em 02/10/2008. Disponível em: } \\
\text { http://www.dgz.org.br }\end{array}$ \\
\hline$\sqrt{20}$ & $\begin{array}{l}\text { MOREIRA, Manoel Palhares; MOURA, Maria Aparecida. Construindo tesauros a partir de } \\
\text { tesauros existentes: a experiência do TCI - Tesauro em Ciência da Informação. } \\
\text { DataGramaZero - Revista de Ciência da Informação, v.7, n.4, Ago. 2006. Acesso em } \\
\text { 02/10/2008. Disponível em: http://www.dgz.org.br }\end{array}$ \\
\hline 77. & $\begin{array}{l}\text { MOREIRA, Solange Silva. O ícone e a possibilidade de informação. Encontros Bibli: revista } \\
\text { eletrônica de Biblioteconomia e Ciência da Informação, Florianópolis, } 2^{\circ} \text { n. especial, } 2^{\circ} \\
\text { sem. 2006. Acesso em 02/10/2008. Disponível em: http://www.periodicos.ufsc.br/index.php/eb }\end{array}$ \\
\hline 78. & $\begin{array}{l}\text { MOREIRO, José Antonio. Criterios e indicadores para evaluar la calidad del análisis } \\
\text { documental de contenido. Ciência da Informação, Brasília, v.31, n.1, p.53-60, jan./abr. } 2002 . \\
\text { Acesso em 02/10/2008. Disponível em: } \underline{\text { http://revista.ibict.br }}\end{array}$ \\
\hline 79. & $\begin{array}{l}\text { MOURA, Maria Aparecida. Ciência da informação e semiótica: conexão de saberes. } \\
\text { Encontros Bibli: revista eletrônica de Biblioteconomia e Ciência da Informação, } \\
\text { Florianópolis, } 2^{\circ} \text { n. especial, } 2^{\circ} \text { sem. 2006. Acesso em 02/10/2008. Disponível em: } \\
\text { http://www.periodicos.ufsc.br/index.php/eb }\end{array}$ \\
\hline 80. & 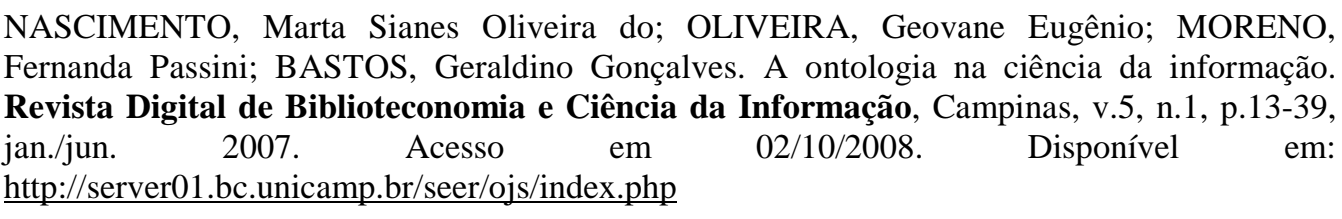 \\
\hline 81. & $\begin{array}{l}\text { NOVELLINO, Maria Salet Ferreira. A linguagem como meio de representação ou de } \\
\text { comunicação da informação. Perspectivas em Ciência da Informação, Belo Horizonte, v.3, } \\
\text { n.2, p.137-146, jul./dez. 1998. Acesso em 02/10/2008. Disponível em: } \\
\text { www.eci.ufmg.br/pcionline }\end{array}$ \\
\hline 82. & $\begin{array}{l}\text { NOVELLINO, Maria Salet Ferreira. Instrumentos e metodologias de representação da } \\
\text { informação. Informação \& Informação, Londrina, v.1, n.2, jul./dez. 1996. Acesso em } \\
\text { 02/10/2008. Disponível em: http://www2.uel.br/revistas/informacao }\end{array}$ \\
\hline 83. & $\begin{array}{l}\text { ORRICO, Evelyn Goyannes Dill. A Representação Metafórica como Filtro de Recuperação da } \\
\text { Informação. DataGramaZero - Revista de Ciência da Informação, v.2, n.5, Out. } 2001 . \\
\text { Acesso em 02/10/2008. Disponível em: } \underline{\text { http://www.dgz.org.br }}\end{array}$ \\
\hline 84. & $\begin{array}{l}\text { ORRICO, Evelyn Goyannes Dill; OLIVEIRA, Carmen Irene Correia de. A representação } \\
\text { metafórica nos caminhos do conhecimento em tempos de comunicação globalizada. }\end{array}$ \\
\hline
\end{tabular}




\begin{tabular}{|c|c|}
\hline & $\begin{array}{l}\text { DataGramaZero - Revista de Ciência da Informação, v.6, n.5, Out. 2005. Acesso em } \\
\text { 02/10/2008. Disponível em: http://www.dgz.org.br }\end{array}$ \\
\hline 85. & $\begin{array}{l}\text { ORTEGA, Cristina Dotta. Fundamentos da organização da informação frente à produção de } \\
\text { documentos. Transinformação, Campinas, v.20, n.1, p.7-15, jan./abr. 2008. Acesso em } \\
\text { 02/10/2008. Disponível em: http://revistas.puc-campinas.edu.br/transinfo/index.php }\end{array}$ \\
\hline 86. & $\begin{array}{l}\text { PAQUARELLI, Maria Luiza Rigo; TÁLAMO, Maria de Fátima Gonçalves Moreira. Sobre a } \\
\text { questão da designação terminológica da disciplina orientação bibliográfica. Ciência da } \\
\text { Informação, Brasília, v.24, n.2. 1995. Acesso em 02/10/2008. Disponível em: } \\
\text { http://revista.ibict.br }\end{array}$ \\
\hline 87. & $\begin{array}{l}\text { PATERNOSTRO, Luiz Carlos Brito. Referir: ref. 'referir'. DataGramaZero - Revista de } \\
\text { Ciência da Informação, v.7, n.5, Out. 2006. Acesso em 02/10/2008. Disponível em: } \\
\text { http://www.dgz.org.br }\end{array}$ \\
\hline 88. & 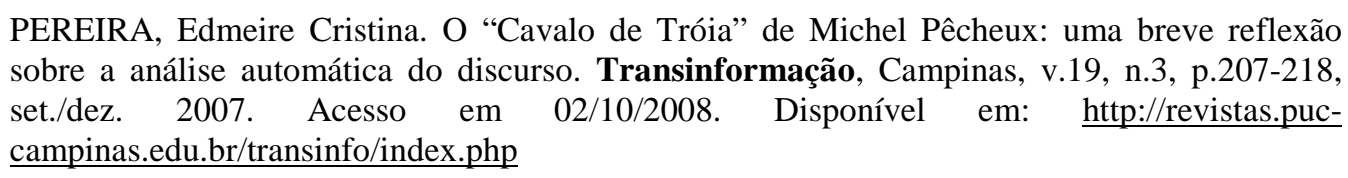 \\
\hline 89. & $\begin{array}{l}\text { PEREIRA, Edmeire Cristina; BUFREM, Leilah Santiago. Princípios de organização e } \\
\text { representação de conceitos em linguagens documentárias. Encontros Bibli: revista eletrônica } \\
\text { de Biblioteconomia e Ciência da Informação, Florianópolis, v.10, n.20, } 2^{\circ} \text { sem. } 2005 \text {. Acesso } \\
\text { em 02/10/2008. Disponível em: http://www.periodicos.ufsc.br/index.php/eb }\end{array}$ \\
\hline 90. & $\begin{array}{l}\text { PÉREZ, María José López-Huertas; TORRES RAMÍREZ, Isabel de. Terminología de género. } \\
\text { Sesgos, interrogantes, posibles respuestas. DataGramaZero - Revista de Ciência da } \\
\text { Informação, v.6, n.5, Out. 2005. Acesso em 02/10/2008. Disponível em: } \\
\text { http://www.dgz.org.br }\end{array}$ \\
\hline 91. & $\begin{array}{l}\text { PINTO, Júlio. Semiótica e informação. Perspectivas em Ciência da Informação, Belo } \\
\text { Horizonte, v.1, n.1, p.87-92, jan./jun. 1996. Acesso em 02/10/2008. Disponível em: } \\
\text { www.eci.ufmg.br/pcionline }\end{array}$ \\
\hline 92. & $\begin{array}{l}\text { PINTO, Virginia Bentes; MEUNIER, Jean-Guy; SILVA NETO, Casemiro. A contribuição } \\
\text { peirciana para a representação indexal de imagens visuais. Encontros Bibli: revista eletrônica } \\
\text { de Biblioteconomia e Ciência da Informação, Florianópolis, v.13, n.25, } 1^{\circ} \text { sem. } 2008 \text {. Acesso } \\
\text { em 02/10/2008. Disponível em: http://www.periodicos.ufsc.br/index.php/eb }\end{array}$ \\
\hline 93. & $\begin{array}{l}\text { POMBO, Olga. Interdisciplinaridade e integração dos saberes. Liinc em revista, v.1, n.1, mar. } \\
\text { 2005. Acesso em 02/10/2008. Disponível em: http://www.liinc.ufrj.br/pt/ }\end{array}$ \\
\hline 94. & $\begin{array}{l}\text { RABELLO, Rodrigo. História dos conceitos e Ciência da Informação: apontamentos teórico- } \\
\text { metodológicos para uma perspectiva epistemológica. Encontros Bibli: revista eletrônica de } \\
\text { Biblioteconomia e Ciência da Informação, Florianópolis, n.26, } 2^{\circ} \text { sem. 2008. Acesso em } \\
\text { 02/10/2008. Disponível em: http://www.periodicos.ufsc.br/index.php/eb }\end{array}$ \\
\hline 95. & $\begin{array}{l}\text { RENDÓN ROJAS, Miguel Ángel. La ciencia de la información en el contexto de las ciencias } \\
\text { sociales y humanas. Ontología, epistemología, metodología e interdisciplina. DataGramaZero } \\
\text { - Revista de Ciência da Informação, v.9, n.4, Ago. 2008. Acesso em 02/10/2008. Disponível } \\
\text { em: http://www.dgz.org.br }\end{array}$ \\
\hline 96. & $\begin{array}{l}\text { RENDÓN ROJAS, Miguel Angel. Relación entre los conceptos: Información, conocimiento y } \\
\text { valor. Semejanzas y diferencias. Ciência da Informação, Brasília, v.34, n.2, p.52-61, }\end{array}$ \\
\hline
\end{tabular}




\begin{tabular}{|c|}
\hline maio/ago. 2005. Acesso em 02/10/2008. Disponível em: http://revista.ibict.br \\
\hline $\begin{array}{l}\text { 97. SALES, Luana Farias; CAMPOS, Maria Luiza de Almeida; GOMES, Hagar Espanha. } \\
\text { Ontologias de domínio: um estudo das relações conceituais. Perspectivas em Ciência da } \\
\text { Informação, Belo Horizonte, v.13, n.2, p.62-76, maio/ago. 2008. Acesso em 02/10/2008. } \\
\text { Disponível em: www.eci.ufmg.br/pcionline }\end{array}$ \\
\hline $\begin{array}{l}\text { 98. SALES, Rodrigo de; CAFÉ; Ligia. Semelhanças e Diferenças entre Tesauros e Ontologias. } \\
\text { DataGramaZero - Revista de Ciência da Informação, v.7, n.4, Ago. 2006. Acesso em } \\
\text { 02/10/2008. Disponível em: } \underline{\text { http://www.dgz.org.br }}\end{array}$ \\
\hline $\begin{array}{l}\text { 99. SALES, Rodrigo. Suportes teóricos para pensar linguagens documentárias. Revista Digital de } \\
\text { Biblioteconomia e Ciência da Informação, Campinas, v.5, n.1, p.95-114, jan./jun. } 2007 . \\
\text { Acesso em 02/10/2008. Disponível em: http://server01.bc.unicamp.br/seer/ojs/index.php }\end{array}$ \\
\hline $\begin{array}{l}\text { 100.SANTANA, Maria Aparecida Lourenço; DIAS, Eduardo José Wense; BORGES, Mônica } \\
\text { Erichen Nassif. Contribuições da psicologia do pensamento e da cognição para os indexadores } \\
\text { relacionais de Farradane. Encontros Bibli: revista eletrônica de Biblioteconomia e Ciência } \\
\text { da Informação, Florianópolis, v.13, n. } 25,1^{\circ} \text { sem. 2008. Acesso em 02/10/2008. Disponível } \\
\text { em: http://www.periodicos.ufsc.br/index.php/eb }\end{array}$ \\
\hline $\begin{array}{l}\text { 101.SMIT, Johanna W; TÁLAMO, Maria de Fátima Gonçalves Moreira; KOBASHI, Nair Yumiko. } \\
\text { A determinação do campo científico da Ciência da Informação: uma abordagem terminológica. } \\
\text { DataGramaZero - Revista de Ciência da Informação, v.5, n.1, Fev. 2004. Acesso em } \\
\text { 02/10/2008. Disponível em: http://www.dgz.org.br }\end{array}$ \\
\hline $\begin{array}{l}\text { 102.SOUZA, Rosali Fernandez de. Organização e representação de áreas do conhecimento em } \\
\text { ciência e tecnologia: princípios de agregação em grandes áreas segundo diferentes contextos de } \\
\text { produção e uso de informação. Encontros Bibli: revista eletrônica de Biblioteconomia e } \\
\text { Ciência da Informação, Florianópolis, n. especial, } 1^{\circ} \text { sem. 2006. Acesso em 02/10/2008. } \\
\text { Disponível em: http://www.periodicos.ufsc.br/index.php/eb }\end{array}$ \\
\hline $\begin{array}{l}\text { 103.TÁLAMO, Maria de Fátima Gonçalves Moreira. A Pesquisa: recepção da informação e } \\
\text { produção do conhecimento. DataGramaZero - Revista de Ciência da Informação, v.5, n.2, } \\
\text { Abr. 2004. Acesso em 02/10/2008. Disponível em: } \underline{\text { http://www.dgz.org.br }}\end{array}$ \\
\hline $\begin{array}{l}\text { 104.TÁLAMO, Maria de Fátima Gonçalves Moreira; LARA, Marilda Lopes Ginez de. O campo da } \\
\text { Linguística Documentária. Transinformação, Campinas, v.18, n.3, p.203-211, set./dez. } 2006 . \\
\text { Acesso em 02/10/2008. Disponível em: http://revistas.puc-campinas.edu.br/transinfo/index.php }\end{array}$ \\
\hline $\begin{array}{l}\text { 105.TÁLAMO, Maria de Fátima Gonçalves Moreira; LENZI, Lívia Aparecida Ferreira. } \\
\text { Terminologia e documentação: a relação solidária das organizações do conhecimento e da } \\
\text { informação no domínio da inovação tecnológica. DataGramaZero - Revista de Ciência da } \\
\text { Informação, v.7, n.4, Ago. 2006. Acesso em } 02 / 10 / 2008 \text {. Disponível em: } \\
\text { http://www.dgz.org.br }\end{array}$ \\
\hline $\begin{array}{l}\text { 106.TÁLAMO, Maria de Fátima Gonçalves Moreira; SMIT, Johanna W. Ciência da Informação: } \\
\text { pensamento informacional e integração interdisciplinar. Brazilian journal of Information } \\
\text { Science, v.1, n.1, p.33-37, jan./jun. 2007. Acesso em: 02/10/2008. Disponível em: } \\
\text { http://www.bjis.unesp.br }\end{array}$ \\
\hline $\begin{array}{l}\text { 107.TRISTÃO, Ana Maria Delazari; FACHIN, Gleisy Regina Bóries; ALARCON, Orestes } \\
\text { Estevam. Sistema de classificação facetada e tesauros: instrumentos para organização do } \\
\text { conhecimento. Ciência da Informação, Brasília, v.33, n.2, p.161-171, maio/ago. 2004. Acesso } \\
\text { em } 02 / 10 / 2008 \text {. Disponível em: http://revista.ibict.br }\end{array}$ \\
\hline
\end{tabular}


108.TRISTÃO, Ana Maria Delazari; FACHIN, Gleisy Regina Bóries; ALARCON, Orestes Estevam; BLATTMANN, Ursula. Sistema de classificação facetada: instrumento para organização da informação sobre cerâmica para revestimento. Informação \& Sociedade: Estudos, João Pessoa, v.12, n.2, p.109-136, jul./dez. 2004. Acesso em 02/10/2008. Disponível em: http://www.ies.ufpb.br/ojs2/index.php/ies

109.UNGER, Roberto J.G.; FREIRE, Isa Maria. Sistemas de informação e linguagens documentárias no contexto dos regimes de informação: um exercício conceitual. Revista Digital de Biblioteconomia e Ciência da Informação, Campinas, v.4, n.1, p.102-115, jul./dez. 2006. Acesso em 02/10/2008. Disponível em: http://server01.bc.unicamp.br/seer/ojs/index.php

110.VÁLIO, Else Benetti Marques; OLIVEIRA, Vanda de Fátima Fulgêncio de. Terminologia da Ciência da Informação: abordagem da análise do discurso. Perspectivas em Ciência da Informação, Belo Horizonte, v.8, n.2, p.114-133, jul./dez. 2003. Acesso em 02/10/2008. Disponível em: $\underline{w w w . e c i . u f m g . b r / p c i o n l i n e}$ 


\section{APÊNDICE B}

\section{TRATAMENTO E ANÁLISE DO CORPUS SELECIONADO}


Tabela 3. Padronizações específicas para a análise.

\begin{tabular}{|c|c|}
\hline Referências nos artigos & Padronização para a análise \\
\hline $\begin{array}{l}\text { MINISTÉRIO DA EDUCAÇÃO E CULTURA. Secretaria da Educação } \\
\text { Superior. Programa Nacional de Bibliotecas Universitárias. Manual de } \\
\text { elaboração de tesauros monolíngues. . Brasília: SESu, 1990. 78p. } \\
\text { (SESu/NBU/Doc. PET/90/02) }\end{array}$ & MINISTÉRIO... \\
\hline $\begin{array}{l}\text { UNESCO. Colóquio Internacional sobre Interdisciplinaridade, Paris. Rio de } \\
\text { Janeiro: Edições Tempo Brasileiro Ltda., } 1992 .\end{array}$ & UNESCO. Colóquio... \\
\hline $\begin{array}{l}\text { NETWORK Digital Library Thesis and Dissertations.Diponível } \\
\text { em: }<\text { http://www.ndltd.org }>\end{array}$ & NETWORK Digital... \\
\hline OPEN archives initiative. Disponível em: $<$ http://www.openarchives.org $>$ & OPEN archives... \\
\hline $\begin{array}{l}\text { PROCEEDINGS of the workshop on the semantic web: models, architectures } \\
\text { and management, Fourth European Conference on Research and Advanced } \\
\text { Technology for digital libraries (ECDL 2000). } \\
\text { http://www.ics.forth.gr/proj/isst/SemWeb/proceedins }>\end{array}$ & PROCEEDINGS... \\
\hline $\begin{array}{l}\text { CLASSIFICATION RESEARCH GROUP. The need for a faceted } \\
\text { classification as the basis of all methods of information retrieval. In: CHAN, } \\
\text { L.M.; RICHMOND, P.A.; SVENONIUS, E. (Ed.) The theory of subject } \\
\text { analysis: a sourcebook. Colorado, Libraries Unlimited, 1985, p.154-167. }\end{array}$ & $\begin{array}{l}\text { CLASSIFICATION } \\
\text { RESEARCH GROUP... }\end{array}$ \\
\hline $\begin{array}{l}\text { UNIVERSITY OF GLAMORGAN. The Facet Projet. 2007. Disponível em: } \\
\text { <http://www.comp.glam.ac.uk/\%7EFACET/>. Acesso em: } 13 \text { jul. } 2007 .\end{array}$ & $\begin{array}{l}\text { UNIVERSITY } \\
\text { GLAMORGAN... }\end{array}$ \\
\hline $\begin{array}{l}\text { AFNOR NF Z47-100: 1981. Règles d'établissement des thésaurus } \\
\text { monolingues. } 20 \mathrm{p} .\end{array}$ & AFNOR NF Z47-100. \\
\hline $\begin{array}{l}\text { BSI 5723:1987. Guidelines for the establishment and development of } \\
\text { monolingual thesauri. } 35 \mathrm{p} \text {. }\end{array}$ & BSI 5723. \\
\hline FID (1973) Committee on Classification Research. & FID $\ldots$ \\
\hline $\begin{array}{l}\text { IBICT (1984) Diretrizes para elaboração de tesauros monolingües. Brasília: } \\
\text { IBICT. } 70 \text { p. art11 }\end{array}$ & IBICT. Diretrizes... \\
\hline $\begin{array}{l}\text { ISO 2788:1986. Documentation guidelines for the establishment and } \\
\text { development of monolingual thesauri. } 2 \text {. ed. } 32 \mathrm{p} \text {. }\end{array}$ & ISO 2788. \\
\hline $\begin{array}{l}\text { UNESCO (1973) Guidelines for the establishment and development of } \\
\text { monolingual thesauri. } 37 \mathrm{p} .\end{array}$ & UNESCO. Guidelines... \\
\hline $\begin{array}{l}\text { AFNOR Z 47-100:1981. Règles d'établissement des thésaurus monolingues. } \\
\text { Paris,AFNOR, 1981. } 20 \text { p. }\end{array}$ & \\
\hline $\begin{array}{l}\text { ANSI Z39.19:1980. American National Standard Guidelines for Thesaurus } \\
\text { Structure, Construction, and Use. Bethesda, Md, NISO, 1980. 20p. }\end{array}$ & ANSI Z39.19. \\
\hline $\begin{array}{l}\text { ANSI/NISO Z 39.19: } 2005 \text { - Guidelines for the construction, format and } \\
\text { management of monolingual controlled vocabularies. Bethesda, Md, NISO, } \\
\text { 2005. } 176 \mathrm{p} \text {. }\end{array}$ & ANSI Z39.19. \\
\hline $\begin{array}{l}\text { BSI BS5723:1979. Guidelines for the establishment and development of } \\
\text { monolinguall thesauri. London, BSI, } 1979.36 \mathrm{p} \text {. }\end{array}$ & BSI 5723 \\
\hline
\end{tabular}


IPHAN.Centro Nacional de Folclore e Cultura Popular. Tesauro de Folclore e Cultura Popular Brasileira .Rio de janeiro, 2005. Disponível em http://www.museudofolclore.com.br/tesauro. Acesso em 28 ago. 2006.

UNESCO. Guidelines for the establishment and development of monolingual thesauri. [s.n.t]. $37 \mathrm{p}$.

IMATERIALIDADES. Atrator Estranho, v.3, n.11, maio, 1995.

ISO. Establishment and development of monolingual thesauri. IO 2788-1986. p.8

FUNDAÇÃO SEADE. Informações sobre os municípios paulistas. Disponível em: <http://www.seade.gov.br/cgi-bin/lingcv98/spd_01.ksh>. Acesso em: 16 maio 2004

INTERNATIONAL ORGANIZATION FOR STANDARDIZATION. British standard guide to establishment and development of monolingual thesauri: 2788. London : BSI, 1986. 2000 .

Principles and methods of terminology: 704. 2. ed. [S. 1. : s. n.],

Terminology work - principles and methods: 1087-1. Part 1: theory and application $=$ Travaux terminologiques - vocabulaire . Partie 1: théorie et application. [S. 1. : s. n.], 2000.

ISO 1087-1. Terminology work - principles and methods. Part 1: theory and application; Travaux terminologiques - vocabulaire. Partie 1: théorie et application. Génève : ISO, 2000.

ISO 2788. British Standard Guide to establishment and development of monolingual thesauri. London: BSI, 1986.

ISO 704. Principles and methods of terminology. 2.ed. Génève : ISO, 2000.

ISO 704. Principles and methods of terminology. 2.ed. [s.1.:s.n] 2000.

ISO 1087-1. Terminology work - principles and methods. Part 1: theory and application; Travaux terminologiques - vocabulaire. Partie 1: théorie et application. [s.l: s.n], 2000-E/F.

ISO 5127/6. Documentation and information - vocabulary - part 6: Documentary languages; Documentation et information - vocabulaire - partie 6: Langages documentaíres. [s.l: s.n], 1983-E/F.

ISO 704 (2000). Principles and methods of terminology. 2.ed.

ISO 1087-1:2000(E/F). Terminology work - principles and methods. Part 1: theory and application; Travaux terminologiques - vocabulaire. Partie 1: théorie et application. 1.ed.

ISO 5127/6(1983-E/F). Documentation and information - vocabulary - part 6: Documentary languages; Documentation et information -vocabulaire - partie 6: Langages documentaíres. 1.ed.

CLASSIFICATION RESEARCH GROUP. The need for a faceted classification as the basis of all methods of information retrieval. In: CHAN, L. M. et al. (Ed.). Theory of subject analysis. Littleton, Col.: Libraries Unlimited, 1985, p.154-167.
IPHAN...

UNESCO. Guidelines...

IMATERIALIDADES...

ISO 2788 .

FUNDAÇÃO SEADE...

ISO 2788.

ISO 704 .

ISO 1087.

ISO 1087.

ISO 2788 .

ISO 704.

ISO 704.

ISO 1087.

ISO $5127 / 6$.

ISO 704.

ISO 1087

ISO $5127 / 6$

CLASSIFICATION

RESEARCH GROUP... 
DICIONÁRIO Aurélio eletrônico século XXI. Rio de Janeiro: Nova Fronteira e Lexicon Informática, 1999. Disponível em CD-rom, versão 3.0.

THE SEMANTIC WEB. Bulletin of The American Society for Information Science and Technology, v. 29, n. 4, apr./may 2003. (Special Section).

WORLD WIDE WEB. In: Wikipédia. Disponível em: <http://pt.wikipedia.org/wiki/World Wide_Web>. Acesso em: 10 jan. 2006.

ANSI Z39.19:1993. American National Standard Guidelines for Thesuarus Structure, Construction, and Use. New York, 1993.

UNESCO. Guidelines for the establishment and development of monolingual thesauri. Paris, 1973. 37 p.

INTERNATIONAL STANDARD ORGANIZATION, Geneva. ISO 10871990; Terminology / Vocabulary. Geneva, 1990.

INTERNATIONAL STANDARD ORGANIZATION ISO, Geneva . ISO 1087-1: 2000; Terminology work - vocabulary- PART 1: theory and application. Geneva, 2000.

BITI - Biblioteconomia, Informação e Tecnologia da Informação. Elaboração de tesauros documentários: tutorial. Disponível em: <http://www.conexaorio.com/biti >. Acesso em: 06 mar. 2005.

CINDOC. Tesauro en Biblioteconomía y Documentación. Disponível em: <http://www.cindoc.csic.es>. Acesso em: 01 jun. 2005.

DOCUTES. Tesauro de Ciencias de la Documentación. Disponível em: <http://www3.unileon.es/dp/abd/tesauro/pagina/tesdocumentacion/docutes.ht $\underline{\mathrm{m}}>$, Acesso em: 01 jun. 2005.

INSTITUTO BRASILEIRO DE INFORMAÇÃO EM CIÊNCIA E TECNOLOGIA - IBICT. Tesauro de Ciência da Informação: versão preliminar. Brasília: IBICT, 1989.

TCI. Tesauro em Ciência da Informação. Disponível em <http://www.inf.pucminas.br/ci/tci>, Acesso em: 01 jul. 2006

WEBCHOIR. The Thesaurus Construction System (TCS). Disponível em: <http://www.webchoir.com>. Acesso em: 01 jun. 2005.

ORGANIZAÇÃO INTERNACIONAL DE NORMALIZAÇÃO. Guia para a elaboração dos vacabulários sistemáticos: exemplo de métodos. Recomendação ISO 919. SL, 1969. 24p.

ORGANIZAÇÃO INTERNACIONAL DE NORMALIZAÇÃO. Principles and methods of terminology. ISO Recomendation 704. SL, 1987. 16p.

ABNT. Métodos para análise de documentos - determinação de seus assuntos e seleção de termos de indexação. Rio de Janeiro, ago. 1992. NBR12676. (Procedimento)

DIRETRIZES para o estabelecimento e desenvolvimento de tesauros monolíngües. Brasília, DF: IBICT/SENAI, 1993. 86 p. (UNESCO; PGI/81/WS/15).

AMERICAN NATIONAL STANDARDS INSTITUTE. Guidelines for the Construction, format and management of monolingual thesauri. Bethesda, USA: American National Standards Institute, 2003. (ANSI Z39.19-2003).
FERREIRA, A. B. de H.

THE SEMANTIC WEB...

WORLD WIDE WEB...

ANSI Z39.19.

UNESCO. Guidelines...

ISO 1087.

ISO 1087.

BITI...

CINDOC...

DOCUTES...

IBICT. Tesauro...

TCI. Tesauro...

WEBCHOIR....

ISO 919.

ISO 704.

ABNT 12676.

AUSTIN, D.; DALE, P.

ANSI Z39.19. 


\begin{tabular}{|c|c|}
\hline $\begin{array}{l}\text { Disponível em <http://www.niso.org/standards/index.html>. Acessado em: } \\
\text { 30.ago.2005. }\end{array}$ & \\
\hline $\begin{array}{l}\text { BIBLIOTECA DIGITAL DE TESES E DISSERTAÇÕES. Instituto Brasileiro } \\
\text { de Informação em Ciência e Tecnologia. Disponível em } \\
\text { <http://bdtd.ibict.br/>. Acessado em: 25.abr.2007. }\end{array}$ & BIBLIOTECA DIGITAL... \\
\hline $\begin{array}{l}\text { INTERNATIONAL STANDARD ORGANIZATION ISO, Genova. ISO } \\
\text { 1087-1:2000; Terminology work: vocabulary. Part 1: theory and application. } \\
\text { Genova, 2000. }\end{array}$ & ISO 1087. \\
\hline $\begin{array}{l}\text { LISA: Library and Information Science Abstracts. Disponível em } \\
\text { <http://www.csa.com/factsheets/lisa-set-c.php>. Acessado em: 25.abr.2007. }\end{array}$ & LISA... \\
\hline 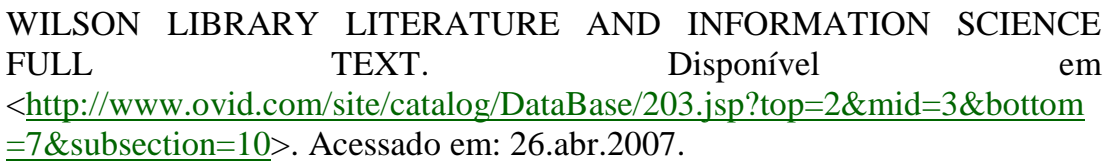 & WILSON LIBRARY... \\
\hline $\begin{array}{l}\text { INTERNATIONAL ORGANIZATION FOR STANDARDIZATION. } \\
\text { International Standard. Terminology work: principles and methods. 2. ed. } \\
\text { 2000. (ISO 704). }\end{array}$ & ISO 704. \\
\hline $\begin{array}{l}\text {. International Standard. Terminology work: vocabulary. } \\
\text { Part } 1-\text { Theory and application. 1. ed. 2000. (ISO 1087-1). }\end{array}$ & ISO 1087. \\
\hline $\begin{array}{l}\text { BRASIL. Lei } \mathrm{n}^{\circ} 10.973 \text {, de } 02.12 .2004 \text {. Dispõe sobre incentivos à inovação e } \\
\text { à pesquisa científica e tecnológica no ambiente produtivo e dá outras } \\
\text { providências. Diário Oficial da União, Brasília, DF, 03 dez. 2004, Seção I, p } \\
\text { 2. Disponível em: <http://www.mct.gov.br/legis/leis/10973 2004.htm>. } \\
\text { Acesso em } 13 \text { jun. } 2005 \text {. }\end{array}$ & BRASIL. Lei $\mathrm{n}^{\circ} 10.973 \ldots$ \\
\hline $\begin{array}{l}\text { ORGANIZAÇÃO PARA COOPERAÇÃO ECONÔMICA E } \\
\text { DESENVOLVIMENTO. Manual de Oslo: proposta de diretrizes para coleta } \\
\text { e interpretação de dados sobre inovação tecnológica. São Paulo: FINEP, } 2004 .\end{array}$ & ORGANIZAÇÃO... \\
\hline $\begin{array}{l}\text { ROGET'S THESAURUS OF ENGLISH WORD AND PHRASES. } \\
\text { London:Longman, } 1970 .\end{array}$ & ROGET'S THESAURUS... \\
\hline $\begin{array}{l}\text { UNESCO. Instituto de Información y Documentación en Ciencia y } \\
\text { Tecnología. Tesauro SPINES. Madrid: UNESCO, } 1988 .\end{array}$ & $\begin{array}{l}\text { UNESCO. Instituto de } \\
\text { Información... }\end{array}$ \\
\hline $\begin{array}{l}\text { CDCON: desenvolvimento de terminologia e codificação de materiais e } \\
\text { serviços para construção - relatório parcial. [S. } 1 .: \text { s. n.], 2003. } 56 \text { p. } \\
\text { Disponível em: Arquivo Beta. Atualizado em: } 17 \text { fev. } 2003 \text {. }\end{array}$ & CDCON: desenvolvimento... \\
\hline $\begin{array}{l}\text { INTERNATIONAL ORGANIZATION FOR STANDARDIZATION. } \\
\text { Classification of information in the construction industry. Geneva, 1994. } 1 \mathrm{v} \text {. } \\
\text { (ISO techical report, 14177). }\end{array}$ & ISO 14177. \\
\hline $\begin{array}{l}\text { KINDS of Concept Maps. University of Illinois ay Urbana-Champaign. } \\
\text { College of Agricultural Consumer and Environmental Sciences. ACES } 100 \\
\text { Discovery Class. The Mind Module. Ago. 2002. Disponível em } \\
\text { <http://classes.aces.uiuc.edu/ACES100/Mind/c-m2.html>. Acesso em abr. } \\
\text { 2003. }\end{array}$ & KINDS of concept... \\
\hline
\end{tabular}


Tabela 4. Total de citações por autor.

CAMPOS, M. L. de A.

DAHLBERG, I.

GUARINO, N.

LARA, M. L. G. de

RANGANATHAN, S. R.

TÁLAMO, M. de F. G. M.

GOMES, H. E.

KOBASHI, N. Y.

VICKERY, B. C.

CABRÉ, M. T.

SARACEVIC, T.

WÜSTER, E.

ECO, U.

BARRETO, A. de A.

CAMPOS, A. T.

CINTRA, A. M. M.

DODEBEI, V. L. D.

ELLIS, D.

GONZÁLEZ DE GÓMEZ, M. N.

GRUBER, T. R.

ISO 1087.

LE MOIGNE, J. L.

MORIN, E.

MOTTA, D. F. da

SOWA, J. F.

AITCHISON, J.

BARBOSA, A. P.

BUCKLAND, M. K.

DELEUZE, G.

GUATTARI, F.

ISO 704.

LANCASTER, F. W.

LÉVY, P.

PINHEIRO, L. V. R.

PRISS, U.

SHERA, J. H.

BELKIN, N. J.

FOUCAULT, $\mathrm{M}$.

GILCHRIST, A.

HJORLAND, B.

JACOB, E. K.

JAPIASSU, H.

KRIEGER, M. G.
42 FUGMANN, R. 1

37 FUNDAÇÃO SEADE...

25 FURLAN, J. D. 1

22 FURNAS, G. W. 1

22 GAINES, B. R. 1

17 GALINSKI, C. 1

15 GALVÃO, M. C. B. 1

15 GANGEMI, A. 1

15 GARCÍA JIMÉNEZ, A. 1

11 GARCÍA MORENTE, $\mathrm{M}$. 1

11 GARZOTTO, F. 1

10 GEERTZ, C. 1

9 GENARO. S. 1

7 GENESERETH, M. R. 1

7 GENNARI, M. C. 1

7 GIBSON, W. 1

7 GIL, F. 1

7 GILES, T. R. 1

7 GNOLI, C. 1

7 GOFFMAN, W. 1

7 GOMEZ-PEREZ, A. 1

7 GOPINATH, M. A. 1

7 GOTLIEB, C. C. 1

7 GRANGER, G. G. 1

7 GRAY, P. M. D. 1

6 GROLIER, E. de. 1

6 GROS, C. 1

6 GUENANCIA, P. 1

6 GUHA, R. V. 1

6 GUILTEN, B. 1

6 GUIMARÃES, E. 1

6 GUIMARÃES, R. F. N. 1

6 GUPTA, D. K. 1

6 GUTIERREZ SAENZ, R. 1

6 HAGGETT, P. 1

6 HAKKARAINEN, M.

5 HALL, W. 1

5 HANESIAN, $\mathrm{H}$. 1

5 HANSSON, J. 1

5 HARVEY, D. 1

5 HEATH, I. 1

5 HEIDEGGER, M. 1

5 HELLER, A. 1 
MOREIRA, A.

SMITH, B.

SPITERI, L. F.

VASCONCELOS, A.

ALARCON, O. E.

ALVARENGA, L.

ANSI Z39.19.

BROOKES, B. C.

BUFREM, L. S.

BUSH, V.

CAPURRO, R.

DUNCAN, E. B.

FACHIN, G. R. B.

FERREIRA, A. B. de H.

INGWERSEN, $P$.

ISO 2788.

KWASNIK, B.

LOPES, E.

LOUREIRO, J. M. M.

OTLET, P.

POLLITT, A. S.

RAYWARD, W. B.

RORTY, R.

SANTOS, B. de S.

TRISTÃO, A. M. D.

USCHOLD, M. A.

ALBRECHTSEN, $\mathrm{H}$.

AUSUBEL, D. P.

BAITELLO JR., N.

BLAHA, M.

CAFÉ, L.

CAMPOS, M. L. M.

DIAS, E. J. W.

DING, Y.

FAULSTICH, E.

FELBER, $\mathrm{H}$.

FOO, $S$.

FOSKETT, A. C.

FOSKETT, D. J.

GARCIA MARCO, F. J.

GARDIN, J. C.

GAUDIN, F.

GLASSEL, A.

JARDIM, J. M.
5 HENDRICKSON, L.

5 HERMAN, J.

5 HERMANS, A.

5 HILL, G.

4 HJELMSLEV, L.

4 HOBSBAWN, E.

4 HOEL, I. A. L.

4 HOLGATE, I.

4 HOMULOS, P.

4 HORNBAEK, K.

4 HOROBIN, D. F.

4 HOVY, E.

4 HOWERTON, P.

4 HUISMAN, D.

4 IBICT. Diretrizes...

4 IBICT. Tesauro...

4 IMATERIALIDADES...

4 INÁCIO FILHO, G.

4 IPHAN...

4 ISO 14177.

4 ISO 919.

4 JASPER R.

4 JONES, K. P.

4 JOSEPHSON, J. R.

4 JUNGBLUT, A. L.

4 JURISTO, N.

3 KAJIKAWA, Y.

3 KATZ, C. S.

3 KAULA, P. N.

3 KAY, M.

3 KELLNER, D.

3 KENEPA, B.

3 KENT, A.

$3 \mathrm{KHOO}, \mathrm{C}$.

3 KILIAN, C.

3 KIM, L.

3 KINDS of concept...

3 KING, M.

3 KLAGGES, B.

3 KLEIN, M.

3 KNELLER, G. F.

3 KNIGHT, K.

3 KOEPSELL, D. R.

3 KORHONEN, P.
1 
KÖHLER, J.

LATOUR, B.

LE GUERN, M.

LIMA, G. A. B.

MILSTEAD, J. L.

OLIVEIRA FILHO, J. J.

PEIRCE, C. S.

ROBERTSON, S. E.

RUMBAUGH, J

SMIT, J. W.

UNESCO. Guidelines...

WELLISCH, H. H.

WELTY, C.

WERSIG, G.

ABBAGNANO, N.

ABU-HANNA, A.

AFNOR Z47-100.

AMORETTI, M. S. M.

ANDERS, G.

ARAÚJO, C. A. A.

AUSTIN, D.

BALPARDA, J.

BARBOSA, G. G.

BARDIN, L.

BARTHES, R.

BAX, M. P.

BEGHTOL, C.

BENVENISTE, E.

BERNERS-LEE, $\mathrm{T}$.

BINWAL, J. C.

BORKO, $\mathrm{H}$.

BOURDIEU, P.

BRACHMAN, R. J.

BROUGHTON, $\mathrm{V}$.

BSI 5723.

BUDIN, G.

CAMINOTTI, L.

CAMPANARIO, J. M.

CAMPOS, L. M.

CASTELLS, M.

CAVALCANTI, C. R.

CHEN, P. P. C.

CLASSIFICATION RESEARCH GROUP...

COMTE, A.
3 KRÜCKEN-PEREIRA, L.

3 KUHN, T.

3 KULKANI, K. G.

3 KUMAR, K.

3 KUMAR, S.

3 KURAMOTO, $\mathrm{H}$.

3 LACOMBE, B. M. B.

3 LAKATOS. E.

3 LALHMACHHUANA, C.

3 LAMPING, J.

3 LANDOW, G. P.

3 LANGE, D.

3 LANZING, J.

3 LARA FILHO, D.

2 LÁSCARIS COMNENO, T.

2 LASTRES, H. M. M.

2 LAUNONEN, R.

2 LAWRENCE, S. S.

2 LEAL, R. P. C.

2 LEE GILES, C.

2 LEICHIK, V. M.

2 LEISE, $\mathrm{F}$.

2 LENAT, D. B.

2 LEPPÄNEN, T.

2 LESKA, B. M.

2 LETHBRIDGE, T. C.

2 LI, M.

2 LIM, L. C.

2 LIMA, V. M. A.

2 LISA...

2 LOMAX, J.

2 LONGO, R. M. J.

2 LÓPEZ YEPES, J.

2 LOUIE, A. J.

2 LÖWY, M.

2 LUCAS, C. R.

2 LUCENA, C. J. P. de. 1

2 LUCKMANN, T. 1

2 LUHN, H.

2 LYNCH, C. A.

2 LYONS, J.

2 LYOTARD, J. F.

2 MACDOUGALL, J.

2 MACEDO, M. M.
1

1

1

1

1

1

1

1

1

1

1

1

1

1

1

1

1

1

1

1

1

1

1

1

1

1

1

1

1

1

1

1

1

1

1

1

1

1

1

1

1

1 
CONKLIN, J.

CRANEFIELD, $\mathrm{S}$.

CURRÁS, E.

DAY, R. E.

DESMET, I.

DROZD, L.

ERDMANN, M.

FENSEL, D.

FERNÁNDEZ-MOLINA, J. C.

FONSECA, M. O.

FOX, M. S.

FUCHS, C.

GARCÍA GUTIÉRREZ, A.

GIARETTA, P.

GRÜNINGER, $M$.

HAAKE, J. M.

HANNEMANN, J.

HEGEL, G. W. F.

HENDLER, J.

HORROCKS, I.

HUNTER, J.

HUTCHINS, W. J.

ISO 5127/6.

JAENECKE, $P$.

KANDELAKI, T. I.

KEIZER, N. F. de.

KOEHLER, W.

KOSELLECK, R.

KUMAR, A.

LANGRIDGE, D.

LASSILA, O.

LE COADIC, Y. F.

MANGIATERRA, N.

MAPLE, A.

MARCONDES, C. H.

MARTÍNEZ, A.

McGUINNESS, D. L.

MENDONÇA DE SOUZA, A. A. C.

MENDONÇA, E. S.

MOREIRA, M. A.

MOREIRA, M. P.

MUELLER, S. P. M.

NEDOBITY, W.

NOVAK, J. D.
2 MACIEL, A. M. B.

2 MADDOX, E. L.

2 MAGALHÃES, G.

2 MAIGUENEAU, D.

2 MALHEIROS, L. R.

2 MANIEZ, J.

2 MANNHEIM, $\mathrm{K}$.

2 MARCONI, M.

2 MARCOS RECIO, J. C.

2 MARGOLIS, $\mathrm{H}$.

2 MARICONDA, P. R.

2 MARQUES DE JESUS, J. B.

2 MARTIN, G. B.

2 MARTIN, W.

2 MARTÍNEZ COMECHE, J. A.

2 MARTÍN-RECUERDA, F.

2 MARX, K.

2 MARZAL, M. A.

2 MASDOLO, C.

2 MAYER, R. E.

2 McCAIN, K.

2 McGARRY, K.

2 MEADOW, C. T.

2 MEDEIROS, M. B. B.

2 MENDES, E. B.

2 MENDONÇA, M. A. R.

2 METAXIOTIS, $\mathrm{K}$.

2 MEYRIAT, J.

2 MIKHAILOV, A. I.

2 MIKSA, F. L.

2 MILET, J.

2 MILLER, G.

2 MILLS, J.

2 MINISTÉRIO...

2 MINSKY, M.

2 MIRANDA, L. M. C. de

2 MONDIN, B.

2 MONTALVO, L. A. M.

2 MONTEIRO, M.

2 MORA, J. F.

2 MOREIRO GONZÁLEZ, J. A.

2 MOREIRO, J.

2 MORENTE, M. G.

2 MOULTHROP, $\mathrm{S}$.
1 
NUNES, B.

OLIVEIRA, M. de.

PEREIRA, E. C.

PIEDADE, M. R.

PISARELLO, R.

PLATÃO.

RABACA, C. A.

RISTUCCIA, C.

RUSSELL, B.

SAGER, J. C.

SANTAELLA, L.

SANTOS. P. X.

SAUSSURE, F. de.

SCHWABE, D.

SOERGEL, D.

SOUZA, R. R.

SPEZIALI, P.

STRAIOTO, A. C.

STUBBS, E.

STUDER, R.

SVENONIUS, E.

TAROUCO, L. M. R.

TEES, $\mathrm{M}$.

THÜRING, M.

VALDEZ, J.

VAN HARMELEN, F.

VICKERY, D. C.

VIOTTI, E. B.

WILSON, T. D.

WORMELL, I.

ZEMAN, J.

ZWETSLOOT-SCHONK, J. H. M.

ABE, K.

ABNT 12676.

ABRAMCZUK, A. A.

ABREU, A. F. de.

ADAMS, A. M.

ADAMS, K.

ALBERTI, V.

ALEXANDER, J.

ALLEN, B. L.

ALMEIDA, E. S. de.

ALVES, R.

ALVIM, P. C. R. de C.
2 MOURA, M. A.

2 MOYA-ANEGÓN, F.

2 MUGALL, C.

2 MUNN, K.

2 MYAENG, S. H.

2 NA, J. C.

2 NARDI, D.

2 NASCIMENTOS, M. M.

2 NAUDÉ, G.

2 NAVES, M. M.

2 NEELAMEGHAN, A.

2 NELSON, R. R.

2 NELSON, T.

2 NETWORK Digital...

2 NEUHAUS, F.

2 NEVELING, U.

2 NEVES, M. H. de M.

2 NILSEN, J.

2 NODA, S.

2 NORVIG, P.

2 NÖTH, W.

2 NOWOSTAWSKI, M.

2 NOY, N. F.

2 NUÑO MORAL, M. V.

2 OFFENSTADT, $\mathrm{N}$.

2 OGDEN, C. K.

2 OLIVEIRA, A. de P.

2 OLIVEIRA, A. M. de.

2 OLIVEIRA, J. de.

2 OLIVEIRA, R. dos A.

2 ONCINA, F.

2 OPDAHL, A. L.

1 OPEN archives...

1 ORGANIZAÇÃO...

1 ORLANDI, E. P.

1 PACHECO, L. S.

1 PAGELS, H. R.

1 PAOLINI, $\mathrm{P}$.

1 PASLARU-BONTAS, E.

1 PASSERON, J. C.

1 PATEL-SCHNEIDER, P. F.

1 PATIL, R.

1 PATON, N. W.

1 PECEGUEIRO, $\mathrm{C}$.
1 
ANALYTI, A.

ANDERS, G. et al.

ARDAILLON, D.

ARISTÓTELES.

ARKADER, R.

ARNAN RIVED, P.

ASKNOUNIS, D.

ASSIS, J. E. de P.

ASSUNÇÃO, J.

AUSSENAC-GILLES, N.

BACCEGA, M. A.

BACHELARD, G.

BAEZA-YATES, R.

BAILEY, K. D.

BARANOW, U. G.

BARBIERI, J. C.

BARROS, L. A.

BATISTA, G. H. R.

BATTACHARYYA, G.

BAUDRILLARD, J.

BAWDEN, D.

BAZARIAN, J.

BEARMAN, D.

BEARMAN, T. C.

BEIGUELMAN, G.

BÉJOINT, H.

BELLUZZO, R. C. B.

BELTRÁN, P.

BENJAMINS, V. R.

BERGER, P.

BERNARDES, R.

BERZITISS, A. T.

BEVILACQUA, C. R.

BIBLIOTECA DIGITAL...

BIDERMAN, M. T.

BIOLCHINI, J. C. de A.

BITI...

BLANQUET, M. F.

BLATTMANN, U.

BLOOR, D.

BOLLACKER K.

BOLTER, J. D.

BONN, G.

BOOTH, W. C.
1 PÉCORA, G. M. 1

1 PEIXOTO, A. S. B. 1

1 PEREIRA, L. R. 1

1 PÉREZ GUTIÉRREZ, M.

1 PERREAULT, $\mathrm{J}$. 1

1 PERRY, J. W. 1

1 PERUZZO, C. 1

1 PESSIS-PASTERNAK, G.

1 PEZATTI, E. G. 1

1 PIEDADE, M. A. 1

1 PINTO, A. V. 1

1 PIROLLI, P. 1

1 PISANELLI, D. $\mathrm{M}$. 1

1 PLASTINO, C. E. 1

1 POLI, R. 1

1 POMBO, O. 1

1 PONTES, F. V. 1

1 POPPER, K. R. 1

1 POSSENTI, S. 1

1 POZZI, M. 1

1 PRASAD, K. N. 1

1 PREMERLANI, $\mathrm{W}$. 1

1 PRESCOTT, L. 1

1 PRIETO-DIAZ, R. 1

1 PRIGOGINE, I. 1

1 PROCEEDINGS...

1 PSARRAS, J. E. 1

1 PURVIS, $\mathrm{M}$. 1

1 PUTTONEN, E. 1

1 RAGHAVAN, K S.

1 RAHMSTORF, G. 1

1 RAMAL, A. C. 1

1 RAMOS, J. 1

1 RAO, R. 1

1 RASMUSSEN, E. M. 1

1 RASTIER, F. 1

1 REAL, M. L. 1

1 RECTOR, A. 1

1 RENFORD, B. 1

1 RIBEIRO, F. 1

1 RIBEIRO-NETO, B. 1

1 RICCIO, E. 1

1 RICHARDS, I. A. 1

1 RICHMOND, $\mathrm{H}$. 1 
BORBA, F. S.

BORGES, J. L.

BOULANGER, J. C.

BOURIGAULT, D.

BRAEKEVELT, P. A. J.

BRAGA, G. M.

BRÄSCHER, $M$.

BRASIL. Lei $n^{\circ} 10.973 \ldots$

BRETON, P.

BRIET, S.

BRITO, M. de.

BRITTAIN, J. M.

BROAD, J.

BRUNO, D.

BRUSCHINI, C.

BRUYNE, P.

BUCHANAN, B. G.

BUCHWEITZ, B.

BUNGE, $\mathrm{M}$.

BURKE, P.

CALDAS AULETE.

CANCLINI, N. G.

CAPPARELLI, S.

CARASTAN, J.

CARDOSO, C.

CASCAIS, F.

CASSIRER, E.

CASTELO BRANCO, P. H. V. B.

CASTILHO, A. T. de.

CDCON: desenvolvimento...

CERVANTES, B. M. N.

CEUSTERS, $\mathrm{W}$.

CHAIBEN, $\mathrm{H}$.

CHAMBOREDON, J. C.

CHANDRASEKARAN, B.

CHARTIER, R.

CHATELET, F.

CHAUÍ, M.

CHAUMIER, J.

CHEN, $\mathrm{H}$.

CHEVALLET, J. P.

CHORLEY, R. J.

CINDOC...

CLADAS, M. P.
1 RIGGS, F. W. A. 1

1 RIVIER, A. 1

1 ROBREDO, J. 1

1 RODRÍGUEZ BRAVO, B. 1

1 ROGET, P. M. 1

1 ROGET'S THESAURUS... 1

1 RONDEAU, G. 1

1 ROSA, M. V. 1

1 ROSE, S. 1

1 ROSSE, C. 1

1 ROSSI, G. 1

1 RÜEGG, A. 1

1 RUSS, T. 1

1 SAKATA, M. 1

1 SALES, L. F. 1

1 SALMON, W. 1

1 SANDER, $\mathrm{S}$. 1

1 SANTOS, I. C. 1

1 SATIJA, M. P. 1

1 SAYÃO, L. F. 1

1 SBRAGIA, R. 1

1 SCHARFFE, $F$. 1

1 SCHLABACH, M. L. 1

1 SCHLICK, C. 1

1 SCHOUERI, R. 1

1 SCHUMPETER, J. A. 1

1 SEETHARAMA, $\mathrm{S}$. 1

1 SEVERINO, A. 1

1 SFEZ, L. 1

1 SHAW, D. 1

1 SHAW, M. 1

1 SHERRATT, C. S. 1

1 SILVA, A. M. da. 1

1 SILVA, C. A. F. da. 1

1 SILVA, F. L. 1

1 SILVA, M. T. C. da. 1

1 SIMPANEN, E. 1

1 SINDRE, G. 1

1 SKUSA, A. 1

1 SMITH, M. P. 1

1 SMITH, R. G. 1

1 SOLURI, A. F. 1

1 SPARCK JONES, $\mathrm{K}$. 1

1 SPYRATOSM, N. 1 
COELHO NETTO, J.

COLMER, A.

CONDAMINES, A.

CONSTANTOPOULOS, P.

COOPER, G. F.

COPI, I. M.

CORAZZON, R.

COSTA, A. F.

COSTA, C. F.

COUGO, P.

CUNHA, I. M. R. F.

DA MATTA, R.

DALE, $P$.

D'ASCENZO, M. D.

DATTA, S.

DAVIS, $\mathrm{H}$.

DE BRUIJN, J.

DEBIASI, F.

DECKER, $\mathrm{S}$.

DEL VALLE GASTAMINZA, F.

DEMANTOVA NETO, C.

DENTON, W.

DERVIN, B.

DEYEDZIC, V.

DIKI-KIDIRI, M.

DINIZ, M.

DOCUTES...

DOERR, M.

DORIA, F. A

DOYLE, L. B.

DUARTE, M. M.

DUBOIS, D.

DUBUC, R.

DUCHEYNE, S.

DUCROT, O.

DUINEVELD, A. J.

DUPUY, J. P.

DZINCHARADZE, A.

ECHEVERRIA, J.

EGAN, M.

EHRIG, M.

EKHOLM, A.

EKLUND, J.

ELKIN, N. J.
1 STAA, A. V.

1 STAAB, A.

1 STENGERS, I.

1 STERNBERG, R.

1 STEVE, G.

1 STIK, G.

1 STOFFLE, C. J.

1 STOKES, D. E.

1 STOTER, R.

1 STREHLOW, R. A.

1 STUMPF, I.

1 SUGAR, W.

1 SUONUUTI, $\mathrm{H}$.

1 SURE, Y.

1 SWARTOUT, B.

1 SWARTOUT, W.

1 TATE, A.

1 TCI. Tesauro...

1 TEIXEIRA COELHO, J.

1 TEMMERMMAN, $\mathrm{R}$.

1 TENÓRIO, R.

1 TERRA, J. C. C.

1 THE SEMANTIC WEB...

1 TILLEY, C. B.

1 TINOCO, $\mathrm{T}$.

1 TODOROV, T.

1 TONELLI, M. J.

1 TÖRNROOS, $\mathrm{H}$.

1 TRIPATHI, G. N.

1 TZITZIKAS, Y.

1 UNBEHAUM, S. G.

1 UNESCO. Colóquio...

1 UNESCO. Instituto de Información...

1 UNIVERSITY OF GLAMORGAN...

1 UUSITALO, P.

1 VALENTE, A.

1 VÄNSKÄ, P.

1 VELTMAN, K. H.

1 VERGEZ, A.

1 VETERE, G.

1 VICKERY, A.

1 VIEIRA, F.

1 VIET, J.

1 VILLACAÑAS, J. L.
1

1

1

1

1

1

1

1

1

1

1

1

1

1

1

1

1

1

1

1

1

1

1

1

1

1

1

1

1

1

1

1

1

1

1

1

1

1

1

1

1

1

1

1 
ENDERTON, H. B. A.

EPSTEIN, I.

ESCHER, M. C.

ESCOBAR, C. H.

FALBO, R. A.

FARRADANE, J.

FEIER, C.

FELDMAN, S.

FERES, O.

FERNANDES, G. C.

FERNANDEZ, M.

FERNÁNDEZ-LÓPES, M.

FERRATER MORA, J.

FEYERABEND, $P$.

FID...

FINQUELIEVICH, S.

FORSYTHE, D. E.

FOX, R.

FRANCELIN, M. M.

FRANCO, C.

FREIRE, I. M.

FREIRE-MAIA, N.

FREITAS, L. S. de.

FRIDQVIST, $\mathrm{S}$.

FROKJAER, E.

FROTA, M. G.
1 VOGEL, M. J. M. 1

1 VUILLEMIN, J.

1 WAHLIN, E. 1

1 WARREN, K. S. 1

1 WASHINGTON, W.

1 WAY, C. E. 1

1 WEBCHOIR.... 1

1 WEIDEN, M. R. 1

1 WEINSTEIN, P. C. 1

1 WEITEN, M. 1

1 WHITE, $\mathrm{H}$. 1

1 WIEDERHOLD, G. 1

1 WILKINS, R. 1

1 WILSON LIBRARY... 1

1 WITTER, G. P. 1

1 WITTGENSTEIN, L. 1

1 WOLEDGE, G. 1

1 WOODWARD, J. 1

1 WORLD WIDE WEB... 1

1 WRIGHT, S. E. 1

1 WYLLIE, J. 1

1 XHOOTHEETE, $M$. 1

1 YUEXIAO, Z.

1 ZIMAN, J. 1

1 ZINGLÉ, $\mathrm{H}$. 1

1 ZINS, C. 1 